\title{
PROBE MOLECULE STUDIES: \\ ACTIVE SPECIES IN ALCOHOL SYNTHESIS
}

\author{
Final Report \\ July 1993 - July 1994 \\ Donna G. Blackmond (PI) \\ Irving Wender (Co-PI) \\ Rachid Oukaci \\ Jian Wang
Department of Chemical and Petroleum Engineering University of Pittsburgh
Pittsburgh, PA 15261

July 1994

Prepared for the U.S. Department of Energy under Grant No. DE-FG22-90PC-90305 


\section{ABSTRACT}

To develop a better understanding of the mechanism of $\mathrm{C}_{2}+$ alcohol formation from $\mathrm{CO} / \mathrm{H}_{2}$ over $\mathrm{Co}-\mathrm{Cu}$ based catalysts, investigations were carried out by several physical and chemical catalyst characterization techniques, alteration of catalyst reduction condition, $\mathrm{CO}$ hydrogenation reaction and in-situ addition of nitromethane as a probe molecule to $\mathrm{CO} / \mathrm{H}_{2}$ at steady state. It was demonstrated that the presence of cobalt in a $\mathrm{Cu} / \mathrm{ZnO}$ based catalyst drastically reduced the activity of $\mathrm{Cu}$ for methanol synthesis and significantly suppressed the promotional effect of $\mathrm{CO}_{2}$ on methanol rurmation by blocking or deactivating the copper metal sites, and the copresence of cobalt metal and copper metal did not necessarily promote the formation rates of $\mathrm{C}_{2}$ alcohols. The reduction treatments using high $\mathrm{H}_{2}$ partial pressure $(\geq 1 \mathrm{~atm})$ at high temperature $\left(>300^{\circ} \mathrm{C}\right)$ were found possible to improve extent of reduction of cobalt without causing sintering of copper metal particles, which consequently increased the local atomic ratio of $\mathrm{Co}^{\circ} / \mathrm{Cu}^{\circ}$ and resulted in dramatic enhancement in the catalyst activity and selectivity for the synthesis of $C_{2} \sim C_{6}$ alcohols. A reasonable particle size of cobalt.metal in contact with copper metal was suggested to be a key factor in constructing the active sites for the formation of $\mathrm{C}_{2}+$ alcohols. The interaction of $\mathrm{CH}_{3} \mathrm{NO}_{2}$ with the reaction network of $\mathrm{CO}$ hydrogenation over the $\mathrm{Cu}$ and $\mathrm{Co}-\mathrm{Cu}$ based catalysts provided evidence suggesting that the aldehydic methanol intermediate formed from $\mathrm{CO}$ and $\mathrm{H}_{2}$ was also involved in the chain growth of $\mathrm{C}_{2^{+}}$alcohol formation. 


\section{DISCLAIMER}

This report was prepared as an account of work sponsored by an agency of the United States Government. Neither the United States Government nor any agency thereof, nor any of their employees, make any warranty, express or implied, or assumes any legal liability or responsibility for the accuracy, completeness, or usefulness of any information, apparatus, product, or process disclosed, or represents that its use would not infringe privately owned rights. Reference herein to any specific commercial product, process, or service by trade name, trademark, manufacturer, or otherwise does not necessarily constitute or imply its endorsement, recommendation, or favoring by the United States Government or any agency thereof. The views and opinions of authors expressed herein do not necessarily state or reflect those of the United States Government or any agency thereof. 


\section{DISCLAIMER}

Portions of this document may be illegible in electronic image products. Images are produced from the best available original document. 


\section{TABLE OF CONTENTS}

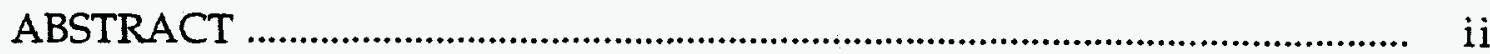

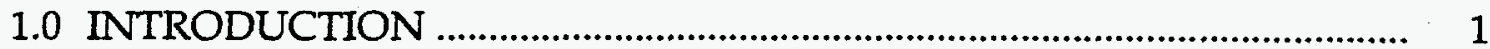

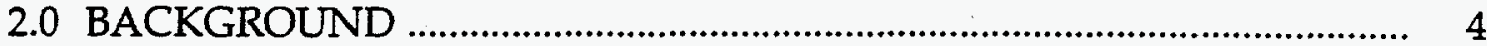

2.1 Mechanisms of Relevant Reactions .................................................... 4

2.1.1 $\mathrm{CH}_{3} \mathrm{OH}$ Synthesis ........................................................................ 4

2.1.1.1 Cu/ZnO Based Catalysts ................................................. 4

2.1.1.2 Group VIII Metal Based Catalysts .................................... 5

2.1.2 Fischer-Tropsch Synthesis ................................................................ 6

2.1.3 Water-Gas-Shift Reaction .............................................................. 8

2.2 Mechanism of Higher Alcohol Synthesis ............................................... 8

2.2.1 Modified $\mathrm{CH}_{3} \mathrm{OH}$ Synthesis Catalysts .......................................... 9

2.2.2 Group VIII Metal Based Catalysts .............................................. 11

2.2.3 Co-Cu Based Catalysts ................................................................... 14

2.3 Probe Molecule Addition in CO Hydrogenation ................................. 16

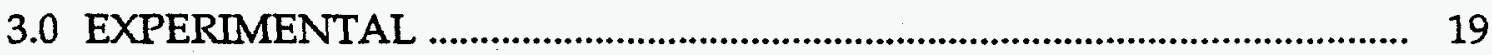

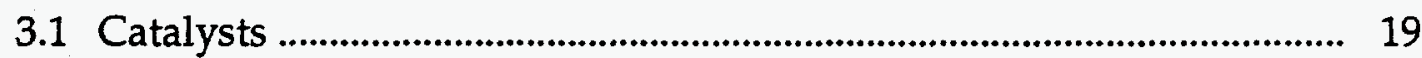

3.1.1 Catalyst Preparation ....................................................................... 19

3.1.1.1 Co Added to a Commercial $\mathrm{CuO} / \mathrm{ZnO} / \mathrm{Al}_{2} \mathrm{O}_{3}$

by Incipient Wetness Impregnation ............................... 19

3.1.1.2 $\mathrm{Co} / \mathrm{Cu} / \mathrm{Zn} / \mathrm{Al}$ Prepared by Coprecipitation .................. 20

3.1.2 Reduction Treatments ................................................................ 21

3.2 Catalyst Characterization ...................................................................... 22

3.2.1 BET Surface Area Measurement ................................................ 22 
3.2.2 Measurements by Thermal Methods ...................................... 23

3.2.2.1 Thermogravimetric Analysis ....................................... 23

3.2.2.2 Temperature Programmed Reduction ........................ 24

3.2.2.3 Temperature Programmed Desorption ....................... 25

3.2.3 X-Ray Diffraction Measurement ............................................... 26

3.2.4 X-Ray Photoelectron Spectroscopy Measurement .................. 27

3.3 Catalytic Reaction ............................................................................. 28

3.3.1 Gas Handling ......................................................................... 29

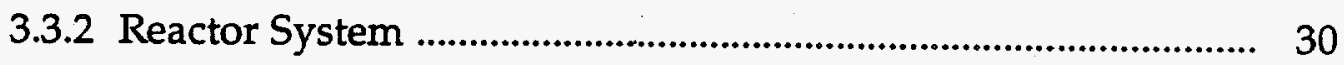

3.3.3 CO Hydrogenation Reaction Conditions .................................. 31

3.3.4 Probe Molecule Addition ........................................................... 31

- 3.3.5 Products Sampling and Analysis .............................................. 32

4.0 CATALYST CHARACTERIZATION …….......................................... 34

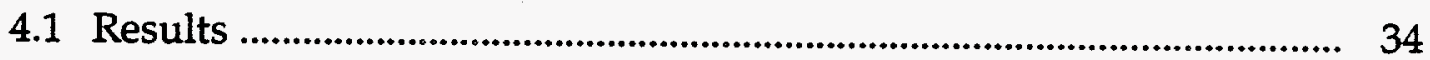

4.1.1 Physical Measurements ............................................................... 34

4.1.1.1 BET Surface Area Measurement …............................... 34

4.1.1.2 Thermogravimetric Analysis ..................................... 35

4.1.1.3 X-Ray Diffraction Measurement ..................................... 35

4.1.1.4 X-Ray Photoelectron Spectroscopy Measurement ..... 38

4.1.2 Chemical Measurements ............................................................ 46

4.1.2.1 Temperature Programmed Reduction …..................... 46

4.1.2.2 Temperature Programmed Desorption of $\mathrm{H}_{2} \ldots \ldots \ldots \ldots . . .55$

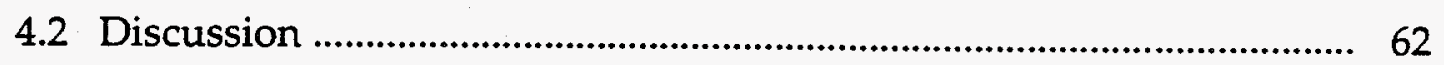

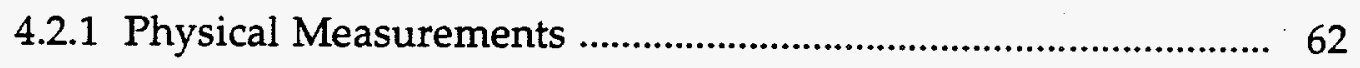

4.2.1.1 Effect of Cobalt-Inclusion in $\mathrm{Cu} / \mathrm{ZnO}$........................... 62 
4.2.1.2 Chemical and Physical States of

Cobalt and Copper

4.2.2 Chemical Measurements ............................................................ 64

4.2.2.1 Extent of Reduction of Cobalt .......................................... 64

4.2.2.2 Interaction between Cobalt and Copper ....................... 64

4.2.2.3 Location of $\mathrm{Co}^{\circ}$ on Catalyst Surface .............................. 67

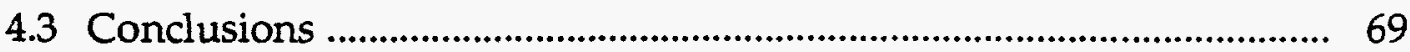

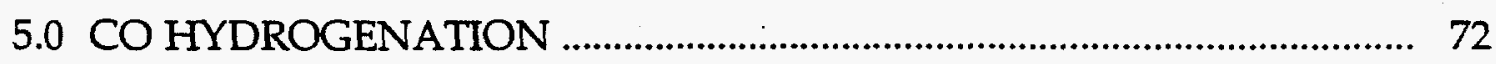

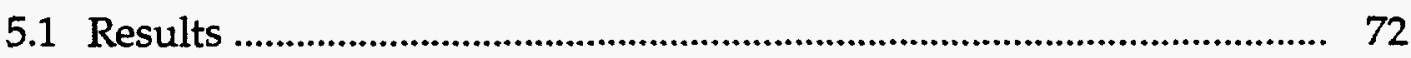

5.1.1 Reduction Treatment A (Standard) ....................................... 72

5.1.2 Reduction Treatment $B$ and $\mathrm{C}$ (High $\mathrm{H}_{2}$ Partial Pressure) .... 75

5.1.3 Effect of $\mathrm{CO}_{2}$ Addition ............................................................ 76

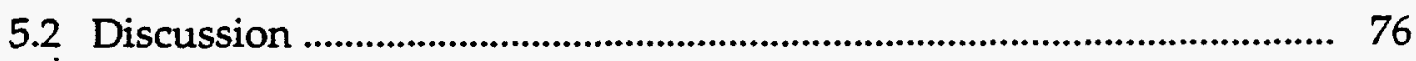

5.2.1 Effect of Presence of Cobalt in $\mathrm{Cu} / \mathrm{ZnO}$................................... 76

5.2.2 Effect of Reduction Treatment Conditions ................................ 79

5.2.3 Effect of Catalyst Preparation Method ......................................... 81

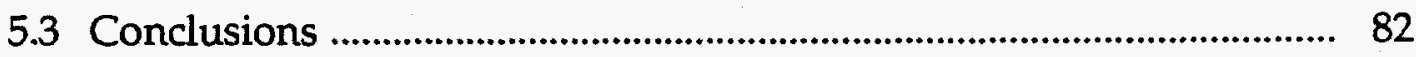

6.0 ADDITION OF NITROMETHANE AS A PROBE MOLECULE ............... 84

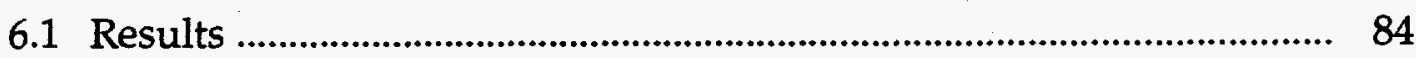

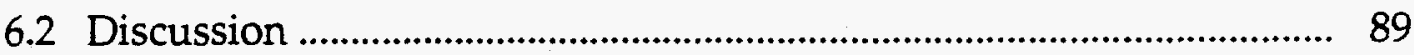

6.2.1 00Co-IW-A and 05Co-IW-A ...................................................... 89

6.2.2 11Co-IW-A and 11Co-IW-B ......................................................... 93

6.2.3 11Co-CP-A and 11Co-CP-B ................................................... 85

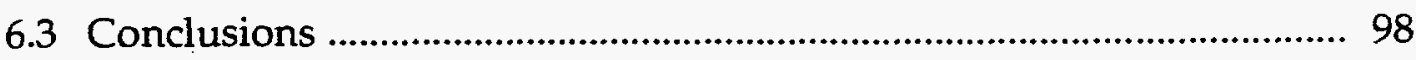

7.0 SUMMARY AND CONCLUSIONS ............................................................. 100 


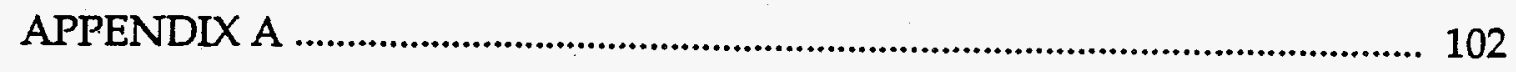

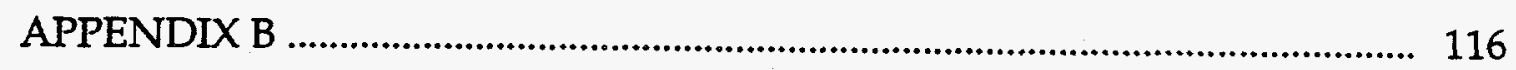

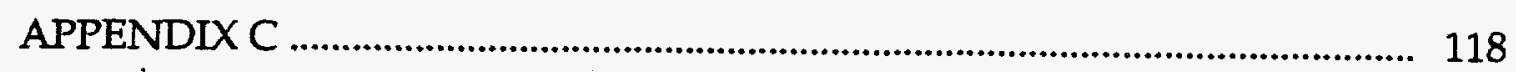

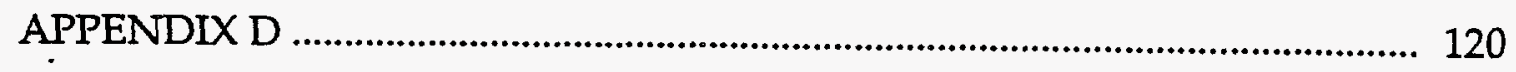

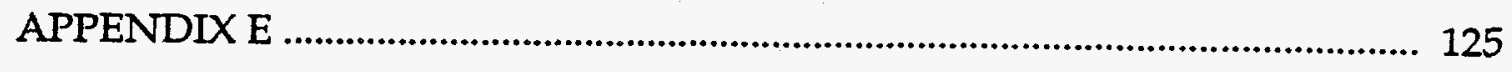

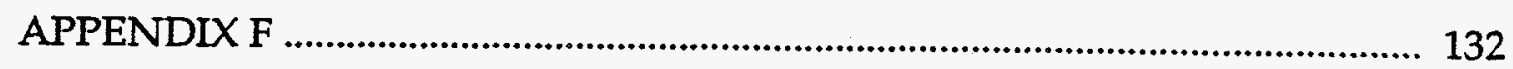

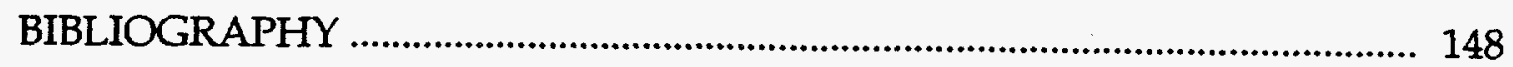




\subsection{INTRODUCTION}

The synthesis of mixed alcohols $\left(C_{1} \sim C_{6}\right.$ alcohols $)$ from $\mathrm{CO} / \mathrm{H}_{2}$ mixtures or syngas is one of the known pathways of indirect liquid fuels synthesis. Increased attention has recently been paid to the synthesis of higher molecular weight alcohols $\left(\mathrm{C}_{2}+\right.$ alcohols $)$ from syngas over heterogeneous catalysts $(1-7)^{*}$ due to the significant requirement of oxygenates in fuels by the Clean Air Act Amendments (CAAA) of 1990 to improve engine performance and decrease pollution. Extensive efforts were put into the production of mixed alcohols from syngas as octane enhancers in gasoline blends during the $1980^{\prime} s^{(1)}$. Compared with low priced methanol, $C_{2}+$ alcohols have higher blending octane numbers and energy content (calorific value), which are key fuels properties, and lower blending vapor pressure (another important fuel property). In addition, using higher alcohols in fuel blends helps to prevent phase separation caused by the presence of a small amount of water.

Various catalyst systems for the synthesis of higher alcohols from $\mathrm{CO} / \mathrm{H}_{2}$ have been developed and widely studied. They can be generally divided into three groups: (1) modified methanol synthesis catalysts ( $\mathrm{Cu} / \mathrm{ZnO}-$ based), (2) group VIII metal based catalysts ( $\mathrm{Rh}, \mathrm{Pd}$-based; modified $\mathrm{Fe}$, Co and $\mathrm{Ni}$ ), and (3) modified molybdenum catalysts ( $\mathrm{MoS}_{x}$-based; Mo/support-based). The production of higher alcohols over these catalysts is often accompanied by formation of methanol and hydrocarbon products. The activity and

* Parenthetical references placed superior to the line of text refer to the bibliography. 
selectivity of higher alcohol synthesis from these catalytic reactions are not very high. There is still a lack of mechanistic knowledge required for the rational design and preparation of catalysts with high activity and satisfactory selectivity as well as for kinetic modeling and process design. A fundamental understanding of the reaction pathways and a clear delineation of critical catalyst structure/performance relationships are desirable from both an industrial and an academic point of view, but this is hampered by the complexity of the process which involves multiple reaction pathways and various catalytic components.

To achieve an understanding of observed activity and selectivity patterns, researchers have attempted to study: (1) the nature of the catalytic sites which are active in the formation of the desired alcohol products; (2) the nature of the surface intermediates or precursors which lead the reaction towards the desired alcohol products; (3) the elementary reactions which make up the reaction pathways, including identification of the rate limiting step. Many experimental methods have been employed to investigate the adsorptive and reactive properties of alcohol synthesis catalysts. Infrared spectroscopy has been used to analyze the bonding state of surface species $(8,9)$. Many other characterization techniques, such as XRD, TEM, adsorption measurements, X-Ray photoelectron spectroscopy, UV spectroscopy, have been applied to generate information about the nature of the surface ${ }^{(8-13)}$. Kinetic parameter studies have been reported to give some suggestions on reaction mechanisms ${ }^{(14)}$. Isotopic labeling of reactants has been introduced to distinguish reaction pathways(15-19). Addition of probe molecules has also been widely used as a tool for mechanistic studies(16-28). 
A wide variety of mechanisms of higher alcohol formation has been proposed based on different experimental results for different catalyst systems $(2-7,9,10,18-23,28-44)$. The alkali (Cs, $\mathrm{K}, \mathrm{Na}$ ) promoted $\mathrm{Cu} / \mathrm{ZnO}$ methanol synthesis catalysts have been most extensively studied(2-4,15, 18). Catalyst systems based on supported Group VIII metals as well as supported Mo have also been widely studied $(2-4,6,7,16,17,19,23)$. The inclusion of Group VIII metals $(\mathrm{Co}, \mathrm{Fe})$ in the $\mathrm{Cu} / \mathrm{ZnO}$ methanol synthesis catalyst system has been studied to a much lesser extent $(5,10,22,40)$, although the $\mathrm{Co} / \mathrm{Cu} / \mathrm{Zn} / \mathrm{Al}$ and $\mathrm{Co} / \mathrm{Cu} / \mathrm{Zn} / \mathrm{Cr}$ catalyst systems have been developed in the $80^{\prime} \mathrm{s}^{(42-44)}$ for the production of $\mathrm{C}_{1}-\mathrm{C}_{6}$ alcohols from syngas. The preparation procedures are believed to be critical to the performance of the final catalyst in HAS. Different views on the mechanism of the formation of $\mathrm{C}_{2}+$ alcohols from $\mathrm{CO} / \mathrm{H}_{2}$ over this type of catalyst have been proposed in the literature, but a consensus has not been reached concerning either the reaction pathways $(2,6$, $22,40)$ or the nature of the active sites $(6,40,45-50)$.

The objectives of this project are to investigate the role(s) of cobalt and copper in constructing the active sites for the formation of higher alcohols from $\mathrm{CO} / \mathrm{H}_{2}$ over the $\mathrm{Co}-\mathrm{Cu}$ based catalysts by using different reduction treatments and applying selected characterization tools such as TPR, TPD, $X R D$ and XPS as well as to generate mechanistic information on the reaction pathway(s) and key intermediate(s) of higher alcohol synthesis from $\mathrm{CO} / \mathrm{H}_{2}$ over $\mathrm{Co}-\mathrm{Cu} / \mathrm{ZnO}$ catalysts by the approach of in-situ addition of a probe molecule (nitromethane). 


\subsection{BACKGROUND}

\subsection{Mechanisms of Relevant Reactions}

Methanol formation, hydrocarbon formation, and the water gas shift reaction are major side reactions in higher alcohol synthesis (HAS) from $\mathrm{CO} / \mathrm{H}_{2}$. Understanding the reaction mechanisms of HAS requires an understanding of these related reactions. Some of the important issues which have been reported in the literature are briefly given below.

\subsection{1 $\mathrm{CH}_{3} \mathrm{OH}$ Synthesis}

The mechanism of methanol synthesis is still the subject of much debate and controversy even though it has been intensively studied $(3,14,16,18,21,29,40$, $51-85)$.

2.1.1.1 $\mathrm{Cu} / \mathrm{ZnO}$ Based Catalysts. It has been generally accepted that $\mathrm{CH}_{3} \mathrm{OH}$ is formed via a non-dissociative mechanism. Conclusive evidence of this mechanism was provided by kinetic studies with isotopic labeling and spectroscopic observation of reaction intermediates $(68)$. Many intermediates, such as formyl, formate, dioxo-methylene, and methoxy, have been reported to play a role in $\mathrm{CH}_{3} \mathrm{OH}$ synthesis $(53,68-71,82)$. Three active states of copper have been proposed and strongly supported in the literature for the active surface sites: (a) metallic copper supported by $\mathrm{ZnO}$ matrix, (b) $\mathrm{Cu}^{\delta+}$ dispersed 
in $\mathrm{ZnO}$ matrix, and (c) a combination of $\mathrm{Cu}^{\circ}$ and $\mathrm{Cu}^{\delta+}$ species that must be in close proximity to one another, and both must be fairly highly dispersed(3). In short, studies concerning the nature of active intermediates and catalytic centers for $\mathrm{Cu} / \mathrm{ZnO}$-based catalysts are the subjects of continued research $(3,8$, 14, 54-61). An induction period for the freshly reduced $\mathrm{Cu} / \mathrm{ZnO}$-based catalyst prior to steady state activity in $\mathrm{CH}_{3} \mathrm{OH}$ synthesis has been widely observed and not well understood yet.

Experimental results have shown that the presence of $\mathrm{CO}_{2}$ in syngas can improve the activity and selectivity towards $\mathrm{CH}_{3} \mathrm{OH}$ dramatically whereas the absence of $\mathrm{CO}_{2}$ accelerates deactivation( $(3,51,52)$. Great attention has been drawn to define the function of $\mathrm{CO}_{2}$. Different mechanisms have been proposed, considering $\mathrm{CO}_{2}$ acting either as true reactant or as a promoter $(3,4$, $15,68,78,79,83,84)$. Recent studies have concluded that the pathway of methanol formation from $\mathrm{CO} / \mathrm{H}_{2}$ is independent of the pathway from $\mathrm{CO}_{2} / \mathrm{H}_{2}(78,83)$. Copper metal has been proposed to compose the active sites for the low pressure methanol synthesis from $\mathrm{CO}_{2} / \mathrm{H}_{2}(52,83,84)$.

2.1.1.2 Group VIII Metal Based Catalysts. Metals like Pd, Pt, or Ir, as well as Rh, chemisorbing $\mathrm{CO}$ associatively, have been cited most frequently $(7,11,12,16$, $35,36,60,62-67,72-77$ ) as being active and selective (though less selective than $\mathrm{Cu} / \mathrm{ZnO}$ catalysts) in $\mathrm{CH}_{3} \mathrm{OH}$ synthesis. This suggests that $\mathrm{CH}_{3} \mathrm{OH}$ formation over these catalysts also occurs via a non dissociative mechanism. Isotopic evidence of this mechanism was demonstrated for the case of $\mathrm{Rh} / \mathrm{TiO}_{2}$ by using a $50-50$ mixture of ${ }^{13} \mathrm{C}^{16} \mathrm{O}$ and ${ }^{12} \mathrm{C}^{18} \mathrm{O}^{(60)}$.

Compared with $\mathrm{Cu} / \mathrm{ZnO}$-based catalysts, some significant differences 
have been reported:

- $\mathrm{CO}_{2}$ and $\mathrm{H}_{2} \mathrm{O}$ have only a minor effect on the synthesis rates over $\mathrm{Pd} / \mathrm{SiO}_{2}{ }^{(30)}$, which is substantially different from the effects observed over $\mathrm{Cu} / \mathrm{ZnO}$-based catalysts;

- alkali addition to $\mathrm{Pd}$ /oxide suppresses the activity of $\mathrm{CH}_{3} \mathrm{OH}$ formation, and does not promote $\mathrm{C}_{2}+$ oxygenate formation ${ }^{(30)}$;

- hydrocarbon formation almost always accompanies alcohol synthesis which results in lower selectivity to $\mathrm{CH}_{3} \mathrm{OH}$ than can generally be achieved over $\mathrm{Cu} / \mathrm{ZnO}$ catalysts.

The observed significant selectivity to $\mathrm{CH}_{3} \mathrm{OH}$ over $\mathrm{Pd}$ /oxide catalysts has drawn much attention $(4,11,16,35,36,63-67,72-77)$. However, research efforts dealing with $\mathrm{CH}_{3} \mathrm{OH}$ formation over this group of catalysts have been less extensive than the work with $\mathrm{Cu} / \mathrm{ZnO}$ catalysts.

\subsubsection{Fischer-Tropsch Synthesis}

The mechanisms of hydrocarbon formation from $\mathrm{CO} / \mathrm{H}_{2}$ over FischerTropsch (F-T) synthesis catalysts have been relatively well studied and reviewed(85-88). It is commonly accepted that the reaction proceeds via a reactive surface carbidic carbon species $\mathrm{CH}_{x}{ }^{*}$ as shown in Figure 1. The $\mathrm{C}-\mathrm{C}$ chain grows through a stepwise $\mathrm{CH}_{\mathrm{x}}{ }^{*}$ insertion or condensation. The hydrogenation of $\mathrm{C}_{\mathrm{n}} \mathrm{H}_{\mathrm{z}}{ }^{*}$ species leads to the products of $\mathrm{F}-\mathrm{T}$ reaction with the observed Anderson-Schulz-Flory (ASF) distribution ${ }^{(89,90)}$. The ASF equation can be expressed as:

$$
\log \left(W_{n} / n\right)=n \log \alpha+\log \left((1-\alpha)^{2} / \alpha\right)
$$


where $W_{n}$ represents the weight fraction of all hydrocarbons containing $n$ carbon atoms, and $\alpha$ represents the chain growth probability defined by

$$
\alpha=R_{p} /\left(R_{p}+R_{t}\right)
$$

where $R_{p}$ represents the rate of chain proporgation and $R_{t}$ represents the rate of chain termination.

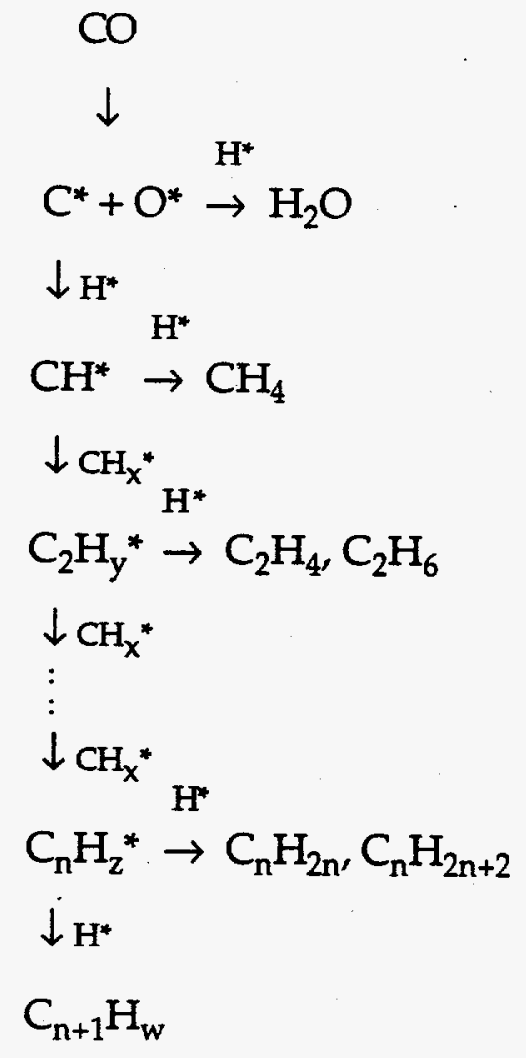

Figure 1 A General Reaction Scheme of Fischer-Tropsch Synthesis ${ }^{(84-87)}$ 


\subsubsection{Water Gas Shift Reaction}

It is known that the presence of the water-gas-shift (WGS) reaction adjusts the ratio between the gas-phase concentration of $\mathrm{CO}, \mathrm{CO}_{2}, \mathrm{H}_{2}$ and $\mathrm{H}_{2} \mathrm{O}$, and possibly also the ratio of the reduced and oxygen-covered part of the $\operatorname{metal}(\mathrm{s})^{(16)}$.

Studies on $\mathrm{Cu}-, \mathrm{Fe}_{3} \mathrm{O}_{4}$ - and $\mathrm{Cs} / \mathrm{Co} / \mathrm{Mo-based}$ catalysts $(15,39,79,88)$ have suggested the following two mechanisms which are most commonly cited:

$$
\begin{aligned}
& \text { (a) } \mathrm{CO}(\mathrm{g}) \rightarrow \mathrm{CO}^{*} \rightarrow \mathrm{HCOO}^{*} \rightarrow \mathrm{CO}_{2}(\mathrm{~g})+\mathrm{H}^{*} \rightarrow \mathrm{H}_{2}(\mathrm{~g}) \\
& \text { (b) } \mathrm{CO}+\mathrm{O}^{*}=\mathrm{CO}_{2}+* \\
& \mathrm{H}_{2} \mathrm{O}+*=\mathrm{H}_{2}+\mathrm{O}^{*}
\end{aligned}
$$

The active surface intermediates suggested are the surface formate species in case (a) and the surface $\mathrm{O}^{*}$ in case (b). Mechanism (b), the so-called regenerative mechanism $(5,15,79,88)$, has been shown to be a dominant( 91$)$ and sensitive ${ }^{(79)}$ reaction on copper-cased catalysts.

\subsection{Mechanism of Higher Alcohol Synthesis}

Among the wide variety of proposed mechanisms of HAS, there are clear differences between the mechanisms developed for modified $\mathrm{CH}_{3} \mathrm{OH}$ synthesis catalysts and those for modified F-T synthesis catalysts. The most significant experimental difference is that the first group of catalysts produce 
large amounts of branched alcohols while the second produce mainly linear primary alcohols. Since Co-Cu based catalysts contain both Group VIII metal and the metal for methanol synthesis, the background on the mechanistic studies of higher alcohol formation over both modified methanol synthesis catalysts and modified Group VIII metal catalysts is very important in the mechanistic study of higher alcohol formation over $\mathrm{Co}-\mathrm{Cu}$ based catalysts.

\subsubsection{Modified $\mathrm{CH}_{3} \mathrm{OH}$ Synthesis Catalysts}

Since early 1930 's, different mechanisms of HAS from $\mathrm{CO} / \mathrm{H}_{2}$ over modified $\mathrm{CH}_{3} \mathrm{OH}$ synthesis catalysts have been proposed $(2,18,21,30-32,37,39,78)$ based on various studies by many research groups.

A general scheme based on a surface $C_{1}$ intermediate with an intact $C-O$ bond ( $\mathrm{CO}, \mathrm{HCO}$ or $\mathrm{HCHO}$ ) adding to an growing alcohol chain was proposed $(30,31)$ (see Figure 2), which includes the aldol-condensation mechanism. This mechanism has been most widely accepted. Another study focusing on identifying surface intermediates ${ }^{(92)}$ proposed that the stepwise addition of $\mathrm{CO}$ into an oxygenated surface species was the primary $\mathrm{C}-\mathrm{C}$ bond forming step in the chain growth (see Figure 3.)

Although each proposed chain growth scheme $e^{(2,30,31,39)}$ explains the formation of branched products, there is still no general agreement on the reaction pathways, the nature of surface intermediates, or the active catalytic centers. 


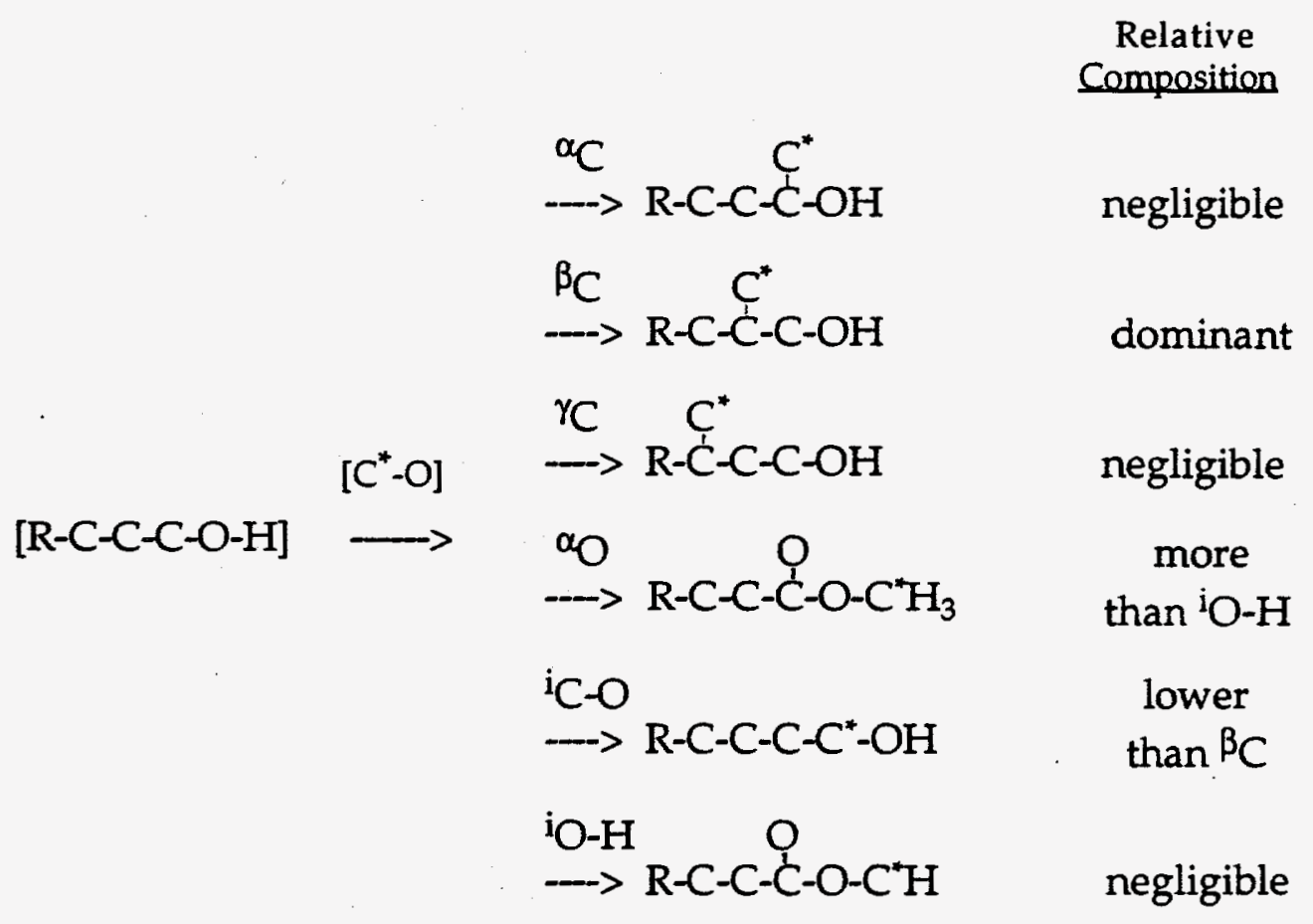

Figure 2 A Proposed Scheme of Higher Alcohol Synthesis Based on $C_{1}$ Intermediate Adding to an Growing Alcohol Chain(30, 31)

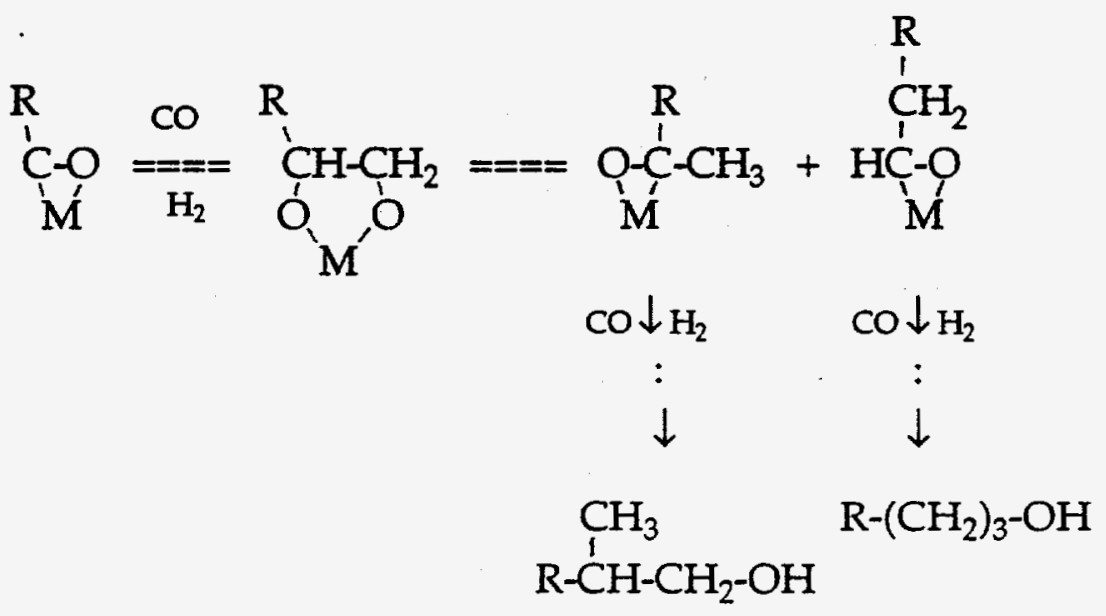

Figure 3 A Proposed Scheme of Higher Alcohol Synthesis Based on Stepwise Addition of $\mathrm{CO}$ on ab Oxygenated Surface Species( ${ }^{(92)}$ 


\subsubsection{Group VIII Metal Based Catalysts}

Most studies have suggested that $\mathrm{CO}$ insertion into $\mathrm{C}_{x} \mathrm{H}_{\mathbf{y}}$ surface species $(5,21,22,29,34,36,37,93,94)$ is an important step in HAS over the group VIII metal based catalysts. However, many details concerning this type of mechanism are still not well understood. There is disagreement on whether the $\mathrm{CO}$ insertion reaction is the initiation, propagation or termination step in the $C-C$ chain growth process for alcohol synthesis. The studies of $C_{2}$ and $C_{2^{+}}$ oxygenates formation $(21,34,37)$ suggest that $\mathrm{CO}$ insertion may play an important role in chain initiation. However, in the proposed scheme for the formation of both $\mathrm{CH}_{3} \mathrm{OH}$ and $\mathrm{C}_{2}$ alcohols $(4,5,95), \mathrm{CO}$ insertion represents the termination step, which can be shown in Figure 4 . It was demonstrated that the $\mathrm{CH}_{\mathrm{x}}{ }^{*}$ species as shown in Figure 4 are not saturated, and $\mathrm{CH}_{3}$ adsorbed on the metal does not lead to further chain growth nor to insertion. According to this scheme, the reaction is expected to produce a series of straight chain terminal alcohols and nonbranched hydrocarbons, each following its own specific ASF distribution. It was suggested that the chain growth for both types of products does not proceed at equal rates because the $\mathrm{CO}$ insertion rate decreases upon increasing the alkyl chain length(95). The formation of higher

alcohols based on this scheme seems to require an ensemble of sites containing both the F-T synthesis sites (for chain propagation) and the sites that adsorb $\mathrm{CO}$ associatively (for chain termination.)

In another proposed scheme (see Figure 5) for the formation of $\mathrm{C}_{2+}$ alcohols(2), $\mathrm{CO}$ insertion is considered as a propagation step, and an acyl intermediate can form. In addition to the alcohols, an alkyl group may be 


$$
\begin{aligned}
& \mathrm{CO} \stackrel{* a}{\rightarrow} \mathrm{CO}^{*} \stackrel{\mathrm{H}^{*}}{\rightarrow} \mathrm{CH}_{3} \mathrm{OH} \\
& \downarrow \text { *d } \\
& \mathrm{C}^{*}+\mathrm{O}^{*} \rightarrow \mathrm{HO} \\
& \downarrow_{\mathrm{H}^{*}}
\end{aligned}
$$

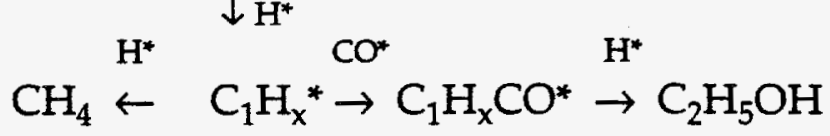

$$
\begin{aligned}
& \downarrow \mathrm{CH}_{x}{ }^{*} \mathrm{CO}^{*} \quad \mathrm{H}^{*} \\
& \mathrm{C}_{2} \mathrm{H}_{4}, \mathrm{C}_{2} \mathrm{H}_{6} \leftarrow \mathrm{C}_{2} \mathrm{H}_{\mathrm{y}}^{*} \rightarrow \mathrm{C}_{2} \mathrm{H}_{\mathrm{y}} \mathrm{CO}^{*} \rightarrow \mathrm{C}_{3} \mathrm{H}_{7} \mathrm{OH} \\
& \downarrow \mathrm{CH}_{\mathrm{x}}{ }^{*} \\
& \text { : } \\
& \downarrow \mathrm{CH}_{\mathrm{x}} * \\
& \mathrm{H}^{*} \mathrm{CO}^{*} \quad \mathrm{H}^{*} \\
& \mathrm{C}_{n} \mathrm{H}_{2 n}, \mathrm{C}_{n} \mathrm{H}_{2 n+2} \leftarrow \mathrm{C}_{n} \mathrm{H}_{2}^{*} \rightarrow \mathrm{C}_{n} \mathrm{H}_{2} \mathrm{CO}^{*} \rightarrow \mathrm{C}_{n+1} \mathrm{C}_{2 n+3} \mathrm{OH} \\
& \downarrow \mathrm{CH}_{\mathrm{x}} * \\
& \mathrm{C}_{\mathrm{n}+1} \mathrm{H}_{\mathrm{w}}{ }^{*}
\end{aligned}
$$

$x, n, z$, and $w$ are integers;

$\mathrm{H}^{*}=$ site for $\mathrm{H}_{2}$ dissociation $\left(\mathrm{Rh}^{0}, \mathrm{Cu}^{0}, \mathrm{Co}^{0}\right)$;

${ }^{*} \mathrm{a}=$ site for associative $\mathrm{CO}$ adsorption $\left(\mathrm{Rh}^{\delta+}, \mathrm{Cu}^{\delta+}, \mathrm{Co}^{\delta+}\right)$;

$* \mathrm{~d}=$ site for dissociative $\mathrm{CO}$ adsorption $\left(\mathrm{Rh}^{0}\right.$ or $\left.\mathrm{Co}^{0}\right)$.

Figure 4 A Proposed Scheme of Alcohol Formation Considering CO Insertion as a Termination Step $(4,5,95)$ 


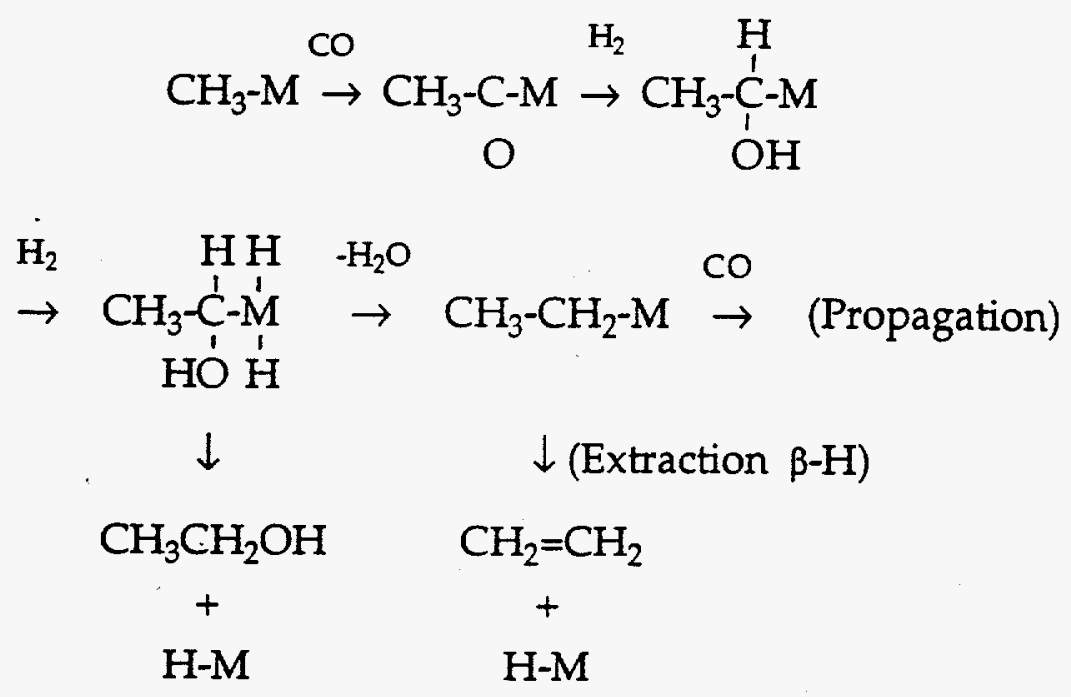

Figure 5 A Proposed Scheme of Alcohol Formation Considering CO Insertion as a Propagation Step ${ }^{(2)}$

produced by dehydration followed by the formation of the corresponding olefin by $\beta$-hydrogen abstraction.

Strong arguments have been given based on theoretical work, studies from homogeneous catalysts and analysis of literature data $(4,93)$ to propose that it is the alkyl group migration rather than $\mathrm{CO}$ insertion that actually occurs on the catalyst surface, as in hydroformylation reactions over homogeneous metal carbonyl complexes. The presence of hydroformylation type reactions (Oxo process ${ }^{(96)}$ ) was also suggested by adding probe molecules to the $\mathrm{CO} / \mathrm{H}_{2}$ feed over heterogeneous $\mathrm{Mo} / \mathrm{SiO}_{2}{ }^{(21)}$ and $\mathrm{Rh}$-based(38) catalysts. An early study of alcohol formation over alkalized Co or Fe catalysts(93) proposed that the insertion/addition of hydroxycarbene species $\left({ }^{*}=\mathrm{CH}-\mathrm{OH}\right)$ 
rather than "CO insertion" was the termination step in a mechanism involving methylene groups in chain growth. A similar idea was proposed again later (22) for HAS over Co-Cu based catalysts.

There are other questions about the mechanisms of $\mathrm{HAS}$ from $\mathrm{CO} / \mathrm{H}_{2}$ remaining to be answered. For example, (a) what is the role of $M^{0}$ and $M^{\delta+}$ in the reaction? (b) what is the role of $\mathrm{CO}_{2}$ other than the function of an oxidizing agent? (c) what is the nature of the active $C_{1}$ and $C_{2}{ }^{+}$oxygenated intermediate?

\subsubsection{Co-Cu Based Catalysts}

Although it has been known that catalysts containing cobalt and copper can be prepared carefully to obtain reasonable activity and selectivity for the synthesis of $\mathrm{C}_{1}-\mathrm{C}_{6}$ alcohols from $\mathrm{CO} / \mathrm{H}_{2}$ with hydrocarbons, $\mathrm{CO}_{2}$ and $\mathrm{H}_{2} \mathrm{O}$ as major by products, the selectivity of these catalysts for the synthesis of $\mathrm{C}_{2^{+}}$ alcohols is generally not high. According to the patent literature(42,44), more than $50 \%$, by weight, of alcohol products is methanol and about $30 \%$ of total alcohol and hydrocarbon products were hydrocarbons. Mechanistic understanding of higher alcohol formation over this type of catalysts has not been well developed. The states and the roles of $\mathrm{Co}$ and $\mathrm{Cu}$ in the synthesis of $\mathrm{C}_{2}-\mathrm{C}_{6}$ alcohols are still not well understood.

The formation of mainly linear (normal primary) alcohols over Co-Cu based catalysts has led to the suggestion of chain growth via F-T mechanism(22,40). Experimental results suggesting the involvement of oxygen-contained $C_{1}$ species in the formation of $\mathrm{C}_{2}+$ alcohols has also been 
reported(22). Consensus has not been reached concerning the reaction pathways and there is a lack of experimental evidences.

Many studies in the literature $(6,40,45-50,97,98)$ have suggested that the enrichment of Co-Cu contact in the catalyst is beneficial for the selective synthesis of $\mathrm{C}_{2}+$ alcohols. However, opinions on the nature of $\mathrm{Co}-\mathrm{Cu}$ contact have been contradictory. Cosimo et. al. ${ }^{(50)}$ proposed that cobalt ions in combination with metallic $\mathrm{Cu}$ or $\mathrm{Cu}-\mathrm{Co}$ phases are important for oxygenate synthesis. Baker et. al. $(46,47)$ concluded that the bimetallic particles of copper and cobalt are not the active site for $\mathrm{C}_{2}$ alcohol synthesis and more complete reduction of cobalt would be disadvantageous although the formation of higher alcohols would be due to the presence of a small amount of metallic cobalt intimately mixed with the copper. They proposed that the key components of a higher alcohol synthesis catalyst are metallic cobalt and unreduced cobalt ions. Bailliard-Letournel et al.(99) reported based on magnetic measurements that bulk $\mathrm{Co}-\mathrm{Cu}$ alloy was never formed with any relative concentration of these two elements or reduction temperature. Assisted by CO-Co FTIR observations, they proposed a so called "cherry model" with a core of pure $\mathrm{Co}^{\circ}$ surrounded by a shell of $\mathrm{Co}-\mathrm{Cu}$ alloy. Dalmon et al(6) proposed that the Co-Cu alloy formed after reduction was the site that activates $\mathrm{CO}$ both in a dissociative and non-dissociative way for the formation of higher alcohols. In all the studies mentioned above, the catalysts were activated at atmospheric pressure, $200 \sim 450^{\circ} \mathrm{C}$ in dilute $\mathrm{H}_{2}$. 


\subsection{Probe Molecule Addition in CO Hydrogenation}

In-situ addition of probe molecules has been demonstrated as a technique capable of providing important insights into the mechanisms of catalytic CO hydrogenation reactions dating from the early $1950 \mathrm{~s}(2,12,18-26,32$, 34, 37). The probe molecules are added in attempts either to generate the same surface species as the precursors or intermediates of the desired products or to react in a specific manner with some of the active surface species. The pathway(s) through which the probe molecules or its fragments are incorporated into the products can be deduced by analyzing the reaction products in absence and presence of the probe molecule. Labeling of the probe molecule with specific isotopes can assist the interpretation of experimental results. An ideal probe molecule is one that can participate in the reactions occurring on the catalyst surface with minimal undesired effects, such as significant perturbation of the ongoing reaction or poisoning of surface sites. Some examples of using probe molecule addition to gain mechanistic information for $\mathrm{CO} / \mathrm{H}_{2}$ reactions are briefly described as following.

Probe molecules such as ethylene, propylene, methanol, ethanol, and acetaldehyde, were added to $\mathrm{CO} / \mathrm{H}_{2}$ feeds over $\mathrm{KCl}$-promoted and unpromoted $\mathrm{Mo} / \mathrm{SiO}_{2}$ catalysts to clarify the reaction paths for the formation of hydrocarbons and alcohols $(21,37)$. The results of olefin addition suggested the presence of mechanistic steps identical with those in the hydrocarbonylation of olefins. Alcohol addition led to the proposal that $\mathrm{CO}$ insertion into the alkyl-metal bond is the main reaction path for higher alcohol formation from $\mathrm{CO} / \mathrm{H}_{2}$. The poor incorporation of acetaldehyde into $\mathrm{C}_{3}$-oxygenates was 
considered as the evidence against the intermediacy of aldehydes in the chain growth of alcohols.

Acetylenic compounds was used as probe molecules for $\mathrm{CO}$ hydrogenation over fused Fe catalysts ${ }^{(23)}$ and the results suggested that monosubstituted acetylenes play the role of an initiator in the synthesis of higher hydrocarbons and oxygenates from $\mathrm{CO}$ and $\mathrm{H}_{2}$. The effect of ethene addition during $\mathrm{F}-\mathrm{T}$. synthesis over a reduced commercial Co catalyst ${ }^{(24)}$ suggested that $C_{2}$ species can participate as a chain initiator.

${ }^{13} \mathrm{C}$ enriched methanol was added as a probe molecule to $\mathrm{CO}$ and $\mathrm{H}_{2}$ for the synthesis of ethanol over methanol synthesis catalysts(32). The results were consistent with a proposed mechanism that involves a $C_{1}$ species which is an intermediate in the formation of both ethanol and methanol. Addition of ${ }^{13} \mathrm{C}$-enriched $\mathrm{CH}_{3} \mathrm{OH}$ and $\mathrm{C}_{2} \mathrm{H}_{5} \mathrm{OH}$ to a $\mathrm{CO} / \mathrm{H}_{2}$ stream over a $\mathrm{Cs} / \mathrm{Cu} / \mathrm{ZnO}$ catalyst suggested that chain growth in $\mathrm{C}_{3^{+}}$primary alcohol formation occurs in a stepwise manner dominated by condensation of a $C_{1}$-oxygenated intermediate at the $\beta$ carbon of the $C_{n}$-oxygenated intermediate while also proceeding via $C_{1}$ linear addition(28). Using isotopically labeled methanol $\left(\mathrm{CD}_{3} \mathrm{OD},{ }^{13} \mathrm{CH}_{3} \mathrm{OH}\right)$ as a probe molecule on a cobalt catalyst ${ }^{(34)}$, ethanol formation by hydrogenation of an ester was proposed.

In previous work by Blackmond and coworkers(25-27), ${ }^{13} \mathrm{CH}_{3} \mathrm{NO}_{2}$ was successfully used as a probe molecule to provide dynamic evidence of the active intermediates and reaction pathways for the formation of hydrocarbons in F-T synthesis. In those studies, $\mathrm{CH}_{3} \mathrm{NO}_{2}$ was used to generate $\mathrm{CH}_{2}$ surface species over supported $\mathrm{Ru}$ catalysts. The substantial random incorporation of ${ }^{13} \mathrm{C}$ into the hydrocarbon product revealed that $\mathrm{CH}_{2}{ }^{*}$ is the 
active intermediate in F-T synthesis and showed that the probe molecule could act as a chain initiator and propagator. It was also demonstrated that the changes in the product distribution took place without significant disturbance of the main reaction pathways leading to hydrocarbon formation. This work suggested the present extension of the use of $\mathrm{CH}_{3} \mathrm{NO}_{2}$ as a probe molecule in the study of the mechanism of higher alcohol formation from $\mathrm{CO} / \mathrm{H}_{2}$. 


\subsection{EXPERIMENTAL}

\subsection{Catalysts}

\subsubsection{Catalyst Preparation and Pretreatment}

\subsubsection{Co Added to a Commercial $\mathrm{Cu} / \mathrm{ZnO} / \mathrm{Al}_{2} \mathrm{O}_{3}$ Catalyst by Incipient} Wetness Impregnation. Two $\mathrm{Co} / \mathrm{Cu} / \mathrm{ZnO} / \mathrm{Al}_{2} \mathrm{O}_{3}$ catalysts were prepared by incipient wetness impregnation of a commercial methanol synthesis catalyst (United Catalysts, Inc.) with aqueous solutions of cobalt nitrate using nominal weight loadings of $5 \%$ and $11 \%$ Co. Prior to impregnation, the commercial methanol synthesis catalyst was calcined in $\mathrm{O}_{2}\left(2 \% \mathrm{O}_{2}\right.$ in $\left.\mathrm{He}, 80 \mathrm{cc} / \mathrm{min}\right)$ at $400^{\circ} \mathrm{C}$ for 8 hours. The impregnated samples were dried at $90^{\circ} \mathrm{C}$ overnight in air. The dried samples were calcined in $\mathrm{O}_{2}\left(2 \% \mathrm{O}_{2}\right.$ in $\left.\mathrm{He}, 80 \mathrm{cc} / \mathrm{min}\right)$ at $400^{\circ} \mathrm{C}$ for 8 hours after increasing the temperature from $25^{\circ} \mathrm{C}$ at $0.5^{\circ} \mathrm{C} / \mathrm{min}$. A $\mathrm{Co}(0 \%) / \mathrm{Cu} / \mathrm{ZnO} / \mathrm{Al}_{2} \mathrm{O}_{3}$ catalyst was prepared as a base catalyst by performing an incipient wetness impregnation using $\mathrm{HNO}_{3}$ instead of $\mathrm{Co}\left(\mathrm{NO}_{3}\right)_{2} \cdot 6 \mathrm{H}_{2} \mathrm{O}$ to obtain an aqueous solution with a $\mathrm{pH}$ value equivalent to the cobaltcontaining samples. The subsequent treatments for this catalyst were the same as for the $5 \%$ Co and $11 \%$ Co samples. In the rest of the text, these three catalysts will be referred as 00Co-IW, 05Co-IW and 11Co-IW based on the nominal weight loadings of $\mathrm{Co}$ over the commercial $\mathrm{Cu} / \mathrm{ZnO} / \mathrm{Al}_{2} \mathrm{O}_{3}$ sample. The catalyst composition is listed in Table 1. 
Table 1 Catalyst Composition ${ }^{a}$

\begin{tabular}{|c|c|c|c|c|c|c|c|}
\hline \multirow[t]{2}{*}{ Catalyst } & \multicolumn{7}{|c|}{ Composition } \\
\hline & Co & $\mathrm{Cu}$ & $\mathrm{Co}_{3} \mathrm{O}_{4}$ & $\begin{array}{l}\mathrm{CuO} \\
(w \mathrm{t} \%\end{array}$ & $\mathrm{ZnO}$ & $\mathrm{Al}_{2} \mathrm{O}_{3}$ & $\mathrm{SiO}_{2}$ \\
\hline 00Co-IW & - & 43.9 & - & 55.0 & 36.0 & 8.0 & 1.0 \\
\hline 05Co-IW & 5.4 & 40.7 & 7.3 & 51.0 & 33.4 & 7.4 & 0.9 \\
\hline $11 \mathrm{Co}-\mathrm{IW}$ & 10.8 & 37.7 & 14.2 & 47.2 & 30.9 & 6.9 & 0.9 \\
\hline $11 \mathrm{Co}-\mathrm{CP}$ & 10.6 & 22.9 & 14.5 & 28.6 & 36.7 & 20.2 & - \\
\hline & & & Co & $\begin{array}{l}\mathrm{Cu} \\
\text { ( at }\end{array}$ & $\begin{array}{l}\mathrm{Zn} \\
\text { nic rat }\end{array}$ & $\begin{array}{r}A l \\
\%)\end{array}$ & $\mathrm{Si}$ \\
\hline 00Co-IW & & & - & 52.9 & 33.8 & 12.0 & 1.3 \\
\hline 05Co-IW & & & 7.1 & 49.2 & 31.4 & 11.1 & 1.2 \\
\hline 11 Co-IW & & . & 14.1 & 45.5 & 29.1 & 10.3 & 1.1 \\
\hline $11 \mathrm{Co}-\mathrm{CP}$ & & & 13.0 & 26.0 & 32.5 & 28.6 & - \\
\hline
\end{tabular}

a: Based on the data information $\left(\mathrm{H}_{2} \mathrm{O}\right.$-free) provided by original sample suppliers (refer the text).

3.1.1.2 $\mathrm{Co} / \mathrm{Cu} / \mathrm{Zn} / \mathrm{Al}$ Prepared by Coprecipitation. Another catalyst studied was prepared by coprecipitation by Cosimo's group(45), which contains $\mathrm{Co}, \mathrm{Cu}$, $\mathrm{Zn}$, and $\mathrm{Al}$ with atomic ratio of $10.6 \mathrm{wt} \% \mathrm{Co}$ (see Table 1). The amorphous precursor was prepared by means of the citric complexing method, decomposed either in air at $500^{\circ} \mathrm{C}$ or in $\mathrm{N}_{2}$ at $280^{\circ} \mathrm{C}$, and calcined in air at $500^{\circ} \mathrm{C}$. This catalyst will be further referred as $11 \mathrm{Co}-\mathrm{CP}$. 


\subsubsection{Reduction Treatments}

Six different reduction conditions, as listed in Table 2, have been used to activate the catalysts in the reactor prior to $\mathrm{CO}$ hydrogenation reaction. In all six cases, the total gas flow rate was controlled at $70 \mathrm{cc} / \mathrm{min}$, the temperature was ramped from $35^{\circ} \mathrm{C}$ at the rate of $0.5^{\circ} \mathrm{C} / \mathrm{min}$ at which the sample was flushed overnight in the reducing gas, to $350^{\circ} \mathrm{C}$ and kept at $350^{\circ} \mathrm{C}$ for 8 hours. The temperature was then lowered to $290^{\circ} \mathrm{C}$ and the pressure was adjusted before beginning reaction studies. In the first reduction condition (A), 3 5\% $\mathrm{H}_{2}$ was mixed with $\mathrm{He}$ and the total pressure was kept at atmospheric pressure. In the second reduction condition (B), the same ratio of $\mathrm{H}_{2}$ to $\mathrm{He}$ was used but the total pressure was controlled at $35 \mathrm{~atm}$. In the third condition (C), pure $\mathrm{H}_{2}$ was used at atmospheric pressure. In order to check the effect of reduction extent achieved in different treatments, three additional reduction conditions (D, E and F) were used in which the catalyst sample first experienced reduction $\mathrm{A}$ (in $\mathrm{D}$ and $\mathrm{E}$ ) or $\mathrm{C}$ (in F) and then, after cooling down

Table 2 Reduction Treatments Applied for Catalyst Activation ${ }^{a}$

\begin{tabular}{lcc}
\hline Descriptors & Pressure, (atm) & $\%$ of $\mathrm{H}_{2}$ in $\mathrm{He}$ \\
A (standard) & 1 & $3 \sim 5$ \\
B (high pressure) & 34 & $3 \sim 5$ \\
C (pure $\mathrm{H}_{2}$ ) & 1 & 100 \\
$\mathrm{D}=$ A then B & & \\
$\mathrm{E}=$ A then C & & \\
$\mathrm{F}=$ C then B & \\
\hline
\end{tabular}

a: Total flow rate $=70 \mathrm{cc} / \mathrm{min}$, weight of sample in the reactor $=250 \pm 2 \mathrm{mg}$. 
to room temperature, underwent reduction $B$ (in $D$ and $F$ ) or $C$ (in $E$ ). Reduction treatment $\mathrm{A}$ resembles the typical reduction conditions reported in the literature $(42 \sim 44,50)$ for activation of the Co-Cu based catalysts.

\subsection{Catalyst Characterization}

\subsubsection{BET Surface Area Measurement}

BET surface area measurements were performed with the as received commercial $\mathrm{CuO} / \mathrm{ZnO} / \mathrm{Al}_{2} \mathrm{O}_{3}$ methanol synthesis catalyst and $05 \mathrm{Co}-\mathrm{IW}$ as well as the post reaction sample of $00 \mathrm{Co}-\mathrm{IW}$ to check whether the treatments in preparing the catalysts by impregnation method as well as the reduction and $\mathrm{CO}$ hydrogenation reaction processes caused any significant surface area loss.

The experiments were carried out on a standard static system with computerized data acquisition. The sample cell could be connected to either vacuum or gas source by solenoid valves to permit evacuation of the cell at one time and introduction of gas at another. The valve control and the pressure reading above the cell were through the computer interfaced with the system. The volumes of the cell as well as the gas storage section above the cell were all pre-calibrated and installed in the computer program.

$\mathrm{N}_{2}$ was used as the adsorption gas and the cell containing the catalyst sample was kept in a liquid $\mathrm{N}_{2}$ bath (i.e. at $-195.8^{\circ} \mathrm{C}$ ) during the adsorption measurements. About $300 \mathrm{mg}$ of each catalyst sample. was used for each measurement. Prior to the adsorption measurement, the sample in the cell 
was evacuated overnight at room temperature. The number of monolayers of $\mathrm{N}_{2}$ adsorbed on the catalyst sample was obtained by introducing known amount of $\mathrm{N}_{2}$ (known volume and pressure at room temperature, with the pressure kept below the normal vapor pressure of $\mathrm{N}_{2}$ at $-195.8^{\circ} \mathrm{C}$ ) to the cell step by step from $\sim 20$ torr to $\sim 260$ torr in an interval of $\sim 40$ torr. At each step, the pressure readings were recorded both before introducing $\mathrm{N}_{2}$ to the cell. and after it was exposed to the sample and allowed to reach equilibrium. The BET equation ${ }^{(100)}$ was applied to obtain the monolayer capacity:

$$
\frac{P}{X\left(P_{o}-P\right)}=\frac{1}{X_{m} C}+\frac{P(C-1)}{P_{o} X_{m} C}
$$

where $X=$ volume adsorbed, $X_{m}=$ monolayer capacity, $P_{0}=$ saturated vapor pressure of $\mathrm{N}_{2}$ at liquid. $\mathrm{N}_{2}$ temperature, $\mathrm{C}=\exp \left[\left(\mathrm{H}_{\mathrm{a}}-\mathrm{H}_{1}\right) / \mathrm{RT}\right], \mathrm{H}_{\mathrm{a}}=$ enthalpy of adsorption in the first layer, $\mathrm{H}_{1}=$ enthalpy liberated on forming the second and subsequent layers. The value of $C$ could be obtained by performing the experiment with a sample with known surface area. $X_{m}$ as well as $C$ can be obtained from the slope and interception of $P / X\left(P_{o}-P\right)$ v.s. $P / P_{o}$.

\subsubsection{Measurements by Thermal Methods}

3.2.2.1 Thermogravimetric Analysis. To measure the water content in the catalyst samples, thermogravimetric Analysis (TGA) was performed on $\mathrm{Hi}$ Res TGA 2950 Thermogravimetric analyzer (TA Instruments) with the as received $\mathrm{CuO} / \mathrm{ZnO} / \mathrm{Al}_{2} \mathrm{O}_{3}$ sample as well as with $00 \mathrm{Co}-\mathrm{IW}, 05 \mathrm{Co}-\mathrm{IW}, 11 \mathrm{Co}$ 
IW and $11 \mathrm{Co}-\mathrm{CP}$. Each sample $(16 \sim 18 \mathrm{mg})$ was heated in $\mathrm{N}_{2}(-90 \mathrm{cc} / \mathrm{min})$ from $30^{\circ} \mathrm{C}$ to $500^{\circ} \mathrm{C}$ at the rate of $2^{\circ} \mathrm{C} / \mathrm{min}$ and held at $500^{\circ} \mathrm{C}$ for 12 hours. The $\mathrm{H}_{2} \mathrm{O}$ content in each sample was calculated based on the percentage of its weight loss after this treatment.

3.2.2.2 Temperature Programmed Reduction. To estimate the relative reduction extent of cobalt in different catalyst samples by the reduction using dilute $\mathrm{H}_{2}$ at atmospheric pressure, one series of TPR experiments were performed with all the catalyst samples listed in Table 1 using a temperature programmed system (Altamira Instruments, Inc. AMI-1) equipped with a TCD detector to measure hydrogen uptake directly. Prior to TPR, the catalyst sample (50 60 mg) loaded in a fixed bed quartz reactor was first heated in flowing $\mathrm{O}_{2}\left(5 \% \mathrm{O}_{2}\right.$ in $\left.\mathrm{He}, 30 \mathrm{cc} / \mathrm{min}\right)$ to $350^{\circ} \mathrm{C}$ at $5^{\circ} \mathrm{C} / \mathrm{min}$, held for 8 hours, then cooled to $50^{\circ} \mathrm{C}$. After flushing with $\operatorname{Ar}(30 \mathrm{cc} / \mathrm{min})$ at $50^{\circ} \mathrm{C}$ for $30 \mathrm{~min}$, TPR was started with $5 \% \mathrm{H}_{2}$ in Ar flowing at $20 \mathrm{cc} / \mathrm{min}$, and the temperature was increased at $1^{\circ} \mathrm{C} / \mathrm{min}$ to $500^{\circ} \mathrm{C} . \mathrm{H}_{2}$ uptake by the catalyst during the reduction process was calculated based on the peak area of the TCD response vs. time. Prior or post to every run, the TCD response was calibrated with controlled pulse(s) of $\mathrm{Ar}$ into a stream of $5 \% \mathrm{H}_{2}$ in $\mathrm{Ar}(20 \mathrm{cc} / \mathrm{min})$. In the estimation of reduction extent of $\mathrm{Co}_{3} \mathrm{O}_{4}$ from the amount of $\mathrm{H}_{2}$ uptake, complete reduction of $\mathrm{CuO}$ was assumed for each sample and the contents of $\mathrm{CuO}$ and $\mathrm{Co}_{3} \mathrm{O}_{4}$ in each catalyst sample were calculated considering the $\mathrm{H}_{2} \mathrm{O}$ content measured from TGA experiment. The experimental errors were obtained from repeated runs.

To study the reduction extent of the catalyst samples from different 
reduction treatments as described in section 3.1.2, another series of TPR experiments were performed with 11Co-CP, 11Co-IW and 00Co-IW using the catalytic reaction system. Due to the the high pressure and the high concentration of $\mathrm{H}_{2}$ in the reduction gas used in treatments $B$ and $C$, respectively, $\mathrm{H}_{2}$ uptake during reduction in this series of experiments was measured by detecting the $\mathrm{H}_{2} \mathrm{O}$ exiting the reactor using the on-line mass spectrometer. The mass spectrometer response for $\mathrm{H}_{2} \mathrm{O}$ was calibrated by saturating the reduction carrier gases $\left(5 \% \mathrm{H}_{2}\right.$ in $\mathrm{He}, 100 \% \mathrm{H}_{2}, \mathrm{H}_{2}: \mathrm{He}=2$ and $100 \% \mathrm{He}$ ) with $\mathrm{H}_{2} \mathrm{O}$ at a known temperature and different equilibrium total pressure to produce curves of $\mathrm{H}_{2} \mathrm{O}$ concentration in the gas stream vs. mass 18 signal on MS. Although the measurement of $\mathrm{H}_{2}$ uptake based on $\mathrm{H}_{2} \mathrm{O}$ detection from MS is less accurate than TCD detection of $\mathrm{H}_{2}$ change in $\mathrm{Ar}$, the trend of the detection from MS is relevant (or representative) to the true values. Experimental descriptions on the reactor system and MS detection setup are given in section 3.3.2 and 3.3.5.

\subsubsection{Temperature Programmed Desorption of $\mathrm{H}_{2}$. To generate information} about the reduced catalyst surface, temperature programmed desorption of $\mathrm{H}_{2}, \mathrm{H}_{2}$-TPD was carried out using the same Altamira Instruments, Inc. (AMI1) apparatus as described in section 3.2.2.2. The catalysts studied by $\mathrm{H}_{2}-\mathrm{TPD}$ were $00 \mathrm{Co}-\mathrm{IW}, 11 \mathrm{Co}-\mathrm{IW}$ and $11 \mathrm{Co}-\mathrm{CP}$. Each catalyst sample ( 100 mg) was first reduced in either $5 \% \mathrm{H}_{2}$ in $\mathrm{Ar}(50 \mathrm{cc} / \mathrm{min})$ or in pure $\mathrm{H}_{2}(50 \mathrm{cc} / \mathrm{min})$ at $350^{\circ} \mathrm{C}$ for 8 hours after ramping from $30^{\circ} \mathrm{C}$ to $350^{\circ} \mathrm{C}$ at $1^{\circ} \mathrm{C} / \mathrm{min}$, and then cooled to $50^{\circ} \mathrm{C}$ naturally in the reduction gas stream. Prior to $\mathrm{H}_{2}-\mathrm{TPD}$, the gas phase $\mathrm{H}_{2}$ in the system was flushed away with $\mathrm{Ar}(50 \mathrm{cc} / \mathrm{min}) . \mathrm{H}_{2}-\mathrm{TPD}$ was then started 
in $\operatorname{Ar}(50 \mathrm{cc} / \mathrm{min})$ at the temperature program of $50^{\circ} \mathrm{C}$ to $300^{\circ} \mathrm{C}$ at $20^{\circ} \mathrm{C} / \mathrm{min}$. Prior or post to every run, the TCD response was calibrated with controlled pulse(s) of Ar into a stream of $5 \% \mathrm{H}_{2}$ in $\mathrm{Ar}(50 \mathrm{cc} / \mathrm{min})$.

\subsubsection{X-Ray Diffraction Measurement}

To gain information about the bulk states of the catalyst components in different samples, series of XRD experiments were performed on a Philips X'Pert system using $\mathrm{CuK} \alpha$ source with the catalyst samples listed in Table 3. The samples post reduction and post reaction were all passivated with $2 \% \mathrm{O}_{2}$ in $\mathrm{He}(70 \mathrm{cc} / \mathrm{min})$ at room temperature and atmospheric pressure.

Table 3 Catalyst Samples for XRD Experiments

\begin{tabular}{|c|c|c|c|c|c|}
\hline \multirow[t]{2}{*}{ Catalyst } & \multirow{2}{*}{$\begin{array}{l}\text { Reduction } \\
\text { Treatment }\end{array}$} & \multicolumn{4}{|c|}{ Catalyst Samples Used for XRD Experiments } \\
\hline & & Calcined $^{b}$ & Reduced & PostCO/H ${ }_{2}{ }^{d}$ & Post $\mathrm{CO} / \mathrm{H}_{2} / \pm \mathrm{CH}_{3} \mathrm{NO}_{2} \mathrm{e}$ \\
\hline 00்Co-IW & A & 00Co-IW-O & 00Co-IW-A & - & - \\
\hline 05Co-IW & A & 05Co-IW-O & 05Co-IW-A & - & - \\
\hline 11 Co-IW & $A$ & 11 Co-IW-O & 11 Co-IW-A & 11 Co-IW-A-R & \\
\hline $11 \mathrm{Co}-\mathrm{IW}$ & B & 11 Co-IW-O & 11Co-IW-B & - & 11 Co-IW-B-R' \\
\hline $11 \mathrm{Co}-\mathrm{CP}$ & $A$ & $11 \mathrm{Co}-\mathrm{CP}-\mathrm{O}$ & $11 \mathrm{Co}-\mathrm{CP}-\mathrm{A}$ & - & 11 Co-CP-A-R' \\
\hline $11 \mathrm{Co}-\mathrm{CP}$ & B & $11 \mathrm{Co}-\mathrm{CP}-\mathrm{O}$ & $11 \mathrm{Co}-\mathrm{CP}-\mathrm{B}$ & $11 C_{0}-\mathrm{CP}-\mathrm{B}-\mathrm{R}$ & 11 Co-CP-B-R' \\
\hline $11 \mathrm{Co}-\mathrm{CP}$ & C & $11 \mathrm{Co}-\mathrm{CP}-\mathrm{O}$ & $11 \mathrm{Co}-\mathrm{CP}-\mathrm{C}$ & $11 \mathrm{Co}-\mathrm{CP}-\mathrm{C}-\mathrm{R}$ & - \\
\hline
\end{tabular}

a: Refer to section 3.1.2 or Table 2 for the description of reduction conditions.

b: Designation $O$ is an indication for calcined samples.

c: Designations A, B and C are the indications for the reduction treatment applied.

d: $R$ and $R^{\prime}$ indicate the samples post reaction without and with $\mathrm{CH}_{3} \mathrm{NO}_{2}$ respectively. 


\subsubsection{X-Ray Photoelectron Spectroscopy Measurement}

With the catalyst samples listed in Table 4, X-Ray Photoelectron Spectroscopy studies were carried out on a modified AEI ES200 sperctrometer equipped with aluminum anode $(\mathrm{Al} \mathrm{K \alpha}=1486.6 \mathrm{eV})$ at a power of $240 \mathrm{~W}$ (12 $\mathrm{KV}$ and $20 \mathrm{~mA}) . \mathrm{Zn} 2 \mathrm{p}\left(1022.1 \mathrm{eV}^{(101)}\right)$ was used as the reference of binding energy values. The instrument was operated in the fixed retardation ratio mode and the analysis pressure was $<5 * 10^{-8}$ torr. The sample reduction treatments were performed in-situ prior to taking XPS spectrum.

Table 4 Catalyst Samples for XPS Experiments

\begin{tabular}{cccc}
\hline Catalyst & Reduction $^{\mathrm{a}}$ & $\begin{array}{c}\text { Catalyst Samples for XPS Experiments } \\
\text { Calcined }^{\mathrm{b}}\end{array}$ & Reduced $^{\mathrm{C}}$ \\
$00 \mathrm{Co}-\mathrm{IW}$ & $\mathrm{A}$ & $00 \mathrm{Co}-\mathrm{IW}-\mathrm{O}$ & $00 \mathrm{Co}-\mathrm{IW}-\mathrm{A}$ \\
$11 \mathrm{Co}-\mathrm{IW}$ & $\mathrm{A}$ & $11 \mathrm{Co}-\mathrm{IW}-\mathrm{O}$ & $11 \mathrm{Co}-\mathrm{IW}-\mathrm{A}$ \\
$11 \mathrm{Co}-\mathrm{CP}$ & $\mathrm{A}$ & $11 \mathrm{Co}-\mathrm{CP}-\mathrm{O}$ & $11 \mathrm{Co}-\mathrm{CP}-\mathrm{A}$ \\
$11 \mathrm{Co}-\mathrm{CP}$ & C & $11 \mathrm{Co}-\mathrm{CP}-\mathrm{O}$ & $11 \mathrm{Co}-\mathrm{CP}-\mathrm{C}$ \\
\hline
\end{tabular}

a: Refer to section 3.1 .2 or Table 2 for the description of reduction conditions.

b: Designation $O$ is an indication for calcined samples.

c: Designations A and B are the indications for the reduction treatment applied.

The atomic ratio of $\mathrm{Co}^{\circ} / \mathrm{Cu}^{\circ}$ on the reduced catalyst surfaces were estimated using the following equation(102): 


$$
\frac{\mathrm{Co}^{\circ}}{\mathrm{Cu}^{\circ}}=\frac{\mathrm{PA}_{\mathrm{Co}^{\circ}} / \mathrm{S}_{\mathrm{Co}}}{\mathrm{PA}_{\mathrm{Cu}^{\circ}} / \mathrm{S}_{\mathrm{Cu}}}
$$

where PA represents the peak area of corresponding metal peak in its XPS $2 p$ spectrum and $S$ is the atomic sensitivity factor. The values of $S$ for cobalt and copper used in the calculation were 2.5 and 4.2, respectively, which were reported in reference (102).

\subsection{Catalytic Reaction}

The catalytic reaction system wised for higher alcohol synthesis from $\mathrm{H}_{2} / \mathrm{CO}$ is shown by Figure 6 , which has the capabilities of adding small amount of probe molecules, either gas or liquid phase, in-situ to the steady state reaction and analyzing the products on-line by both GC and MS. Detailed descriptions of the system as well as the experimental conditions and procedures are given below.

\subsubsection{Gas Handling}

$\mathrm{H}_{2}$ (UHP, Liquid Carbonic Specialty Gas Co.), CO (CP grade, Liquid Carbonic Specialty Gas Co.) and $\mathrm{CO}_{2}$ (Precision Aquator, Matheson Gas Products, Inc.) were employed as reaction gases. He (UHP, Liquid Carbonic Specialty Gas Co.) was used for pretreatments, blank tests and system flushing. 4A molecular sieve traps (Linde high pressure purifiers) were installed on 


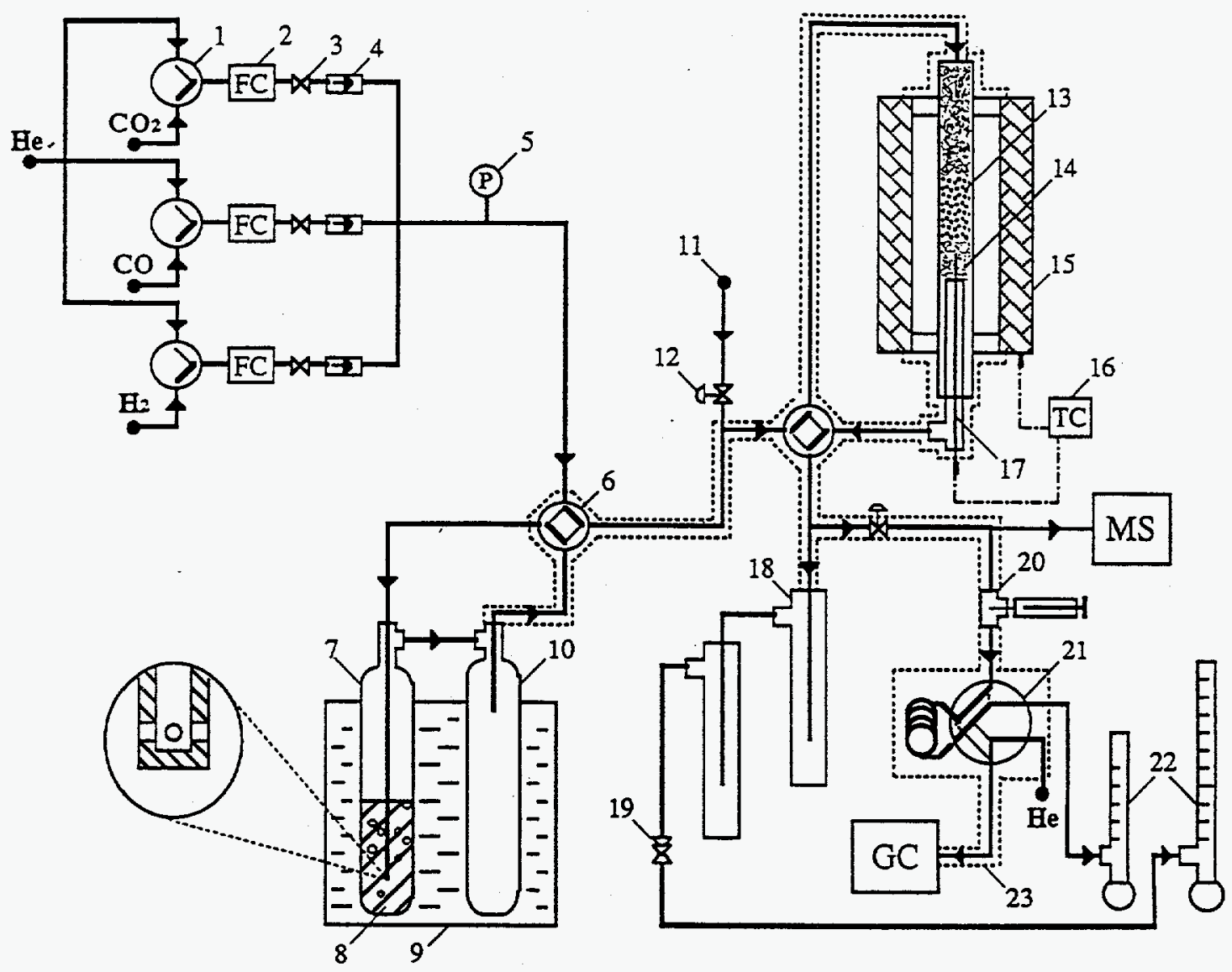

1: 3-way valve, 2 : flow control meter, 3 : on/off valve, 4 : check valve, 5: pressure gauge, 6: 4-way valve, 7: probe molecule saturator, 8: liquid probe molecule, 9: temperature controlled bath, 10: trap, 11: gas probe molecule, 12: metering valve, 13: catalyst, 14: glass wool, 15: furnace, 16: temperature controller, 17: thermocouple, 18: products trap, 19: backup pressure regulator, 20: syringe sampler, 21: 6-way sampling valve, 22: bubble flow meter, 23: heating tape/insulator.

Figure 6 Reaction System for Studies on Alcohol Synthesis from $\mathrm{CO} / \mathrm{H}_{2}$ Capable of In-situ Addition of Probe Molecules 
each gas introduction line to remove traces of $\mathrm{H}_{2} \mathrm{O}$. An Activated Carbon high pressure purifier (Scott) was used on the $\mathrm{CO}$ line to remove traces of hydrocarbons and metal carbonyls. $\mathrm{H}_{2}, \mathrm{CO}, \mathrm{CO}_{2}$ and $\mathrm{He}$ could be introduced to the system either separately or mixed in a desired combination. The flow rate of each gas was controlled by mass flow controllers and could be calibrated with a bubble flow meter at the outlet.

$\mathrm{He}$ (UHP) and $\mathrm{H}_{2}$ (UHP) and HC-free compressed air (Ultra Zero, THC < 0.1 ppm, all Liquid Carbonic Specialty Gas Co.) were used for GC analysis. An oxygen trap (Scott Specialty Gases) was used on the $\mathrm{H}_{2}$.

\subsubsection{Reactor System}

The catalyst sample (50 500 $\mathrm{mg}$ ) was placed in the middle section of a fixed bed reactor (14" long, 3/8" O.D. stainless steel tube) filled with glass wool. The reactant gas mixture was introduced from the top of the reactor and the reaction products exited the reactor from the bottom. The reactor was heated.by an external shell furnace which could be programmed to ramp and hold at desired temperatures. The temperature inside the reactor was measured by a thermocouple positioned directly beneath the catalyst bed. The system pressure was controlled by a back pressure regulator downstream and measured by a pressure gauge upstream from the reactor. 


\subsubsection{CO Hydrogenation Reaction Conditions}

$\mathrm{CO}$ hydrogenation reactions were carried out at $500 \mathrm{psig}, 290^{\circ} \mathrm{C}, \mathrm{H}_{2} / \mathrm{CO}=2$, GHSV $=6000 \sim 60000 \mathrm{hr}^{-1}$. The total carbon conversion was controlled at $\sim 2 \%$ by varying the catalyst sample amount. The effect of $\mathrm{CO}_{2}$ on the $\mathrm{CO}$ hydrogenation reactions over the non-cobalt and cobalt-containing catalysts was studied by switching the gas mixture of $\mathrm{H}_{2}: \mathrm{CO}: \mathrm{CO}_{2}: \mathrm{He}=80: 40: 0: 2$ to $\mathrm{H}_{2}: \mathrm{CO}: \mathrm{CO}_{2}$ : $\mathrm{He}=80: 40: 2: 0(\mathrm{cc} / \mathrm{min})$.

After the reduction treatment, the gas mixture of $\mathrm{H}_{2}+\mathrm{He}=80+40 \mathrm{cc} / \mathrm{min}$ was initiated and the system pressure was increased to 500 pisg (after reduction I and III) with the reactor temperature controlled at $290^{\circ} \mathrm{C}$. The gas flow was then switched to bypass the reactor, and the reaction gas mixture of $\mathrm{H}_{2}+\mathrm{CO}=80+40 \mathrm{cc} / \mathrm{min}$ was initiated, switching back to flowing through the reactor to begin the $\mathrm{CO}$ hydrogenation study.

\subsubsection{Probe Molecule Introduction}

Liquid probe molecules were stored in a saturator which was set in a temperature controlled bath. The probe molecule was added by diverting the gas mixture through the saturator via a 4-way valve. Prior to $\mathrm{CO}$ hydrogenation reaction, the pressure in the saturator was increased to the reaction pressure with the reactant gas mixture after pre-flushing. The amount of probe molecule added into the reactant stream could be varied by varying the temperature of the bath.

Gas phase probe molecules were added through a high pressure, high 
temperature, chemicals-resistant metering valve placed before the 4-way valve for the reactor. The amount of probe molecule added into the reactant stream could be varied by adjusting the metering valve at a constant upstream pressure of the probe molecule.

The probe molecule was added at preset concentrations into the $\mathrm{H}_{2}$ / CO stream $(120 \pm 2 \mathrm{cc} / \mathrm{min})$ after the reaction attained steady state. After a new steady state of the reaction in the presence of the probe molecule was achieved (3 5 hours), the probe molecule addition was stopped by switching the gas flow to bypass the saturator. The $\mathrm{CO}$ hydrogenation reaction was then continuously monitored to observe if the origiral steady state could be reestablished, as an indication of any poisoning effects introduced by the presence of the probe molecule.

\subsubsection{Products Sampling and Analysis}

A high pressure, high temperature, chemicals-resistant metering valve was installed on a line diverted from the reactor outlet before the first trap to allow a small gas flow to a GC sampling valve and an on-line mass spectrometer (Dycor Electronics Inc., M 100M). All the lines from the reactor outlet to the on-line sampling section were heated to avoid product condensation. The GC (Varian 3000) was equipped with both FID and TCD detectors and with a Porapak- $R$ and a Porapak- $Q$ column in series.

In order to be able to detect products formed in amounts too small to be detected by on-line gas phase sample injection, the products from the outlet of the reactor were collected during the reaction period by two traps in series 
cooled with ice in water. The traps were placed downstream after the metering valve for GC sampling and before the back pressure regulator. The lines before the first trap from the reactor were heated during the reaction to prevent product condensation. The liquid sample(s) from the trap(s) after the reaction were analyzed by a GC-MS (Extrel Series 800 ) using He (UHP, Liquid Carbonic Specialty Gas Co.) as carrier gas. 


\subsection{CATALYST CHARACTERIZATION}

\subsection{Results}

\subsubsection{Physical Measurements}

4.1.1.1 BET Surface Area Measurement. Table 5 shows the results of surface area measurement with the selected catalyst samples. The preparation and reduction treatments caused an increase in the surface area of the as received $\mathrm{CuO} / \mathrm{ZnO} / \mathrm{Al}_{2} \mathrm{O}_{3}$. No significant change in sample surface area was caused by the addition of cobalt to the commercial $\mathrm{CuO} / \mathrm{ZnO} / \mathrm{Al}_{2} \mathrm{O}_{3}$ catalyst. The catalyst prepared by coprecipitation had similar surface area to those prepared by impregnation.

Table 5 Results of BET Surface Area Measurement

\begin{tabular}{ccc}
\hline Catalysta & \multicolumn{2}{c}{ BET Surface Area } \\
& Average, $\left(\mathrm{m}^{2} / \mathrm{g}\right)$ & Error, $\% \mathrm{~b}$ \\
$\mathrm{CuO} / \mathrm{ZnO} / \mathrm{Al}_{2} \mathrm{O}_{3}$ & 41 & 0.7 \\
$00 \mathrm{Co}-\mathrm{IW}-\mathrm{A}-\mathrm{R}$ & 57 & 5.6 \\
$05 \mathrm{Co}-\mathrm{IW}-\mathrm{A}$ & 60 & 6.8 \\
$11 \mathrm{Co}-\mathrm{CP}$ & $60 \sim 65^{\mathrm{c}}$ & \\
\hline
\end{tabular}

\footnotetext{
a: Refer to Table 3 for sample name.

b: Determined from repeated runs.

c: Obtained from reference (45).
} 
4.1.1.2 Thermogravimetric Analysis. Table 6 lists the water content in each catalyst sample measured by its weight loss from the TGA experiments. It was used to obtain the sample composition in the estimation of sample reduction extent based on $\mathrm{H}_{2}$-uptakes of TPR experiments (see Table 10).

4.1.1.3. X-Ray Diffraction Measurement. The XRD spectra of the samples listed in Table 3 are shown by Figure A1 A7 in Appendix A. Table 7 shows the comparison between the spectra of different samples which received different treatments in Figure A1 A7.

The XRD spectra of calcined samples in Figure A1 A4 indicated that in all the samples prior to reduction copper was present in the state of $\mathrm{CuO}$ and cobalt was in the state of $\mathrm{CO}_{3} \mathrm{O}_{4}$ which are the most stable oxidation states of these two elements. The XRD spectra of reduced samples in Figure A1 A4 indicated that in all the catalyst samples reduced by different reduction

Table $6 \mathrm{H}_{2} \mathrm{O}$ Content of the Catalyst Samples Measured by Weight Loss from TGA Experiments ${ }^{a}$

\begin{tabular}{lccc}
\hline Catalyst & $\begin{array}{c}\text { Sample Size } \\
(\mathrm{mg})\end{array}$ & $\begin{array}{c}\text { Weight loss } \\
(\mathrm{mg})\end{array}$ & $\begin{array}{c}\mathrm{H}_{2} \mathrm{O} \text { Content } \\
(\mathrm{wt} \%)\end{array}$ \\
00Co-IW & 17.65 & 0.43 & 2.4 \\
05Co-IW & 16.29 & 0.81 & 5.0 \\
$11 \mathrm{Co}-\mathrm{IW}$ & 17.92 & 0.79 & 4.4 \\
$11 \mathrm{Co}-\mathrm{CP}$ & 17.19 & 2.34 & 13.6 \\
\hline
\end{tabular}

a: Each sample $(16 \sim 18 \mathrm{mg})$ was heated in $\mathrm{N}_{2}(\sim 90 \mathrm{cc} / \mathrm{min})$ from $30^{\circ} \mathrm{C}$ to $500^{\circ} \mathrm{C}$ at the rate of $2^{\circ} \mathrm{C} / \mathrm{min}$ and held at $500^{\circ} \mathrm{C}$ for 12 hours. 
Table 7 Comparison of XRD Spectra

\begin{tabular}{|c|c|c|c|c|}
\hline Figure & \multicolumn{4}{|c|}{ XRD Spectra of Catalyst Samples Compared in Figures A1 A6 } \\
\hline & \multicolumn{4}{|c|}{ Effect of Stepwise Experience } \\
\hline$\#$ & Calcined & $\underline{\text { Reduced }}$ & $\underline{\text { Post } \mathrm{CO} / \mathrm{H}_{2}}$ & Post $\mathrm{CO} / \mathrm{H}_{2} \angle \pm \mathrm{CH}_{3} \mathrm{NO}_{2}$ \\
\hline A1 (a) & $11 \mathrm{Co}-\mathrm{CP}-\mathrm{O}$ & $11 \mathrm{Co}-\mathrm{CP}-\mathrm{A}$ & - & $11 \mathrm{Co}-\mathrm{CP}-\mathrm{A}-\mathrm{R}^{\prime}$ \\
\hline $\mathrm{A} 1(\mathrm{~b})$ & $11 \mathrm{CO}-\mathrm{CP}-\mathrm{O}$ & $11 \mathrm{Co}-\mathrm{CP}-\mathrm{B}$ & 11Co-CP-B-R & $11 \mathrm{Co}-\mathrm{CP}-\mathrm{B}-\mathrm{R}^{\prime}$ \\
\hline $\mathrm{A} 1(\mathrm{c})$ & $11 \mathrm{Co}-\mathrm{CP}-\mathrm{O}$ & $11 \mathrm{Co}-\mathrm{CP}-\mathrm{C}$ & $11 \mathrm{Co}-\mathrm{CP}-\mathrm{C}-\mathrm{R}$ & - \\
\hline A2 (a) & 11Co-IW-O & 11Co-IW-A & 11Co-IW-A-R & - \\
\hline A2 (b) & $11 \mathrm{Co}-\mathrm{IW}-\mathrm{O}$ & 11Co-IW-B & - & 11 Co-IW-B-R' \\
\hline A3 & 05Co-IW-O & 05Co-IW-A & - & - \\
\hline \multirow[t]{3}{*}{ A4 } & 00Co-IW-O & OOCo-IW-A & - & - \\
\hline & \multicolumn{4}{|c|}{ Effect of Coablt-Addition } \\
\hline & $00 \mathrm{C}_{0}$-IW & & $05 \mathrm{C}_{0}$-IW & 11 Co-IW \\
\hline A5 $(x)$ & 00 Co-IW-O & & 05Co-IW-O & $11 \mathrm{Co}-\mathrm{IW}-\mathrm{O}$ \\
\hline \multirow[t]{3}{*}{ A5 $(y)$} & OOCo-IW-A & & 05Co-IW-A & 11 Co-IW-A \\
\hline & \multicolumn{4}{|c|}{ Effect of Different Reduction Treatment } \\
\hline & Reduction A & & Reduction B & Reduction C \\
\hline$A 6(x)$ & $11 \mathrm{Co}-\mathrm{CP}-\mathrm{A}$ & & $11 \mathrm{Co}_{0} \mathrm{CP}-\mathrm{B}$ & $11 \mathrm{Co}-\mathrm{CP}-\mathrm{C}$ \\
\hline A6 (y) & $11 \mathrm{Co}-\mathrm{CP}-\mathrm{A}-\mathrm{R}^{\prime}$ & & 11Co-CP-B-R & $11 \mathrm{Co}-\mathrm{CP}-\mathrm{C}-\mathrm{R}$ \\
\hline$A 7(x)$ & 11Co-IW-A & & $11 \mathrm{Co}-\mathrm{IW}-\mathrm{B}$ & 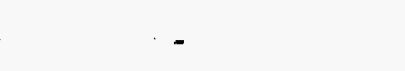 \\
\hline$A 7(y)$ & 11 Co-IW-A-R & & 11 Co-IW-B-R' & - \\
\hline
\end{tabular}

a: The XRD spectra are presented in Figure A1 A7 of Appendix A. 
Table 8 Phases Detected by XRD in the Catalyst Samples

\begin{tabular}{|c|c|c|c|c|c|}
\hline $\begin{array}{l}\text { Catalyst } \\
\text { name }\end{array}$ & $\begin{array}{l}\text { [Metal] } \\
\text { component }\end{array}$ & $\begin{array}{l}\text { Calcined } \\
\text { samples }\end{array}$ & $\begin{array}{l}\text { Reduced } \\
\text { samples }\end{array}$ & $\begin{array}{c}\text { Post } \mathrm{CO} / \mathrm{H}_{2} \\
\text { samples }\end{array}$ & $\begin{array}{c}\text { Post } \mathrm{CO} / \mathrm{H}_{2} / \pm \mathrm{CH}_{3} \mathrm{NO}_{2} \\
\text { samples }\end{array}$ \\
\hline \multirow[t]{3}{*}{$11 \mathrm{Co}-\mathrm{CP}$} & {$[\mathrm{Co}]$} & $\mathrm{Co}_{3} \mathrm{O}_{4}$ & * & $\mathrm{Co}_{3} \mathrm{O}_{4}$ & $\mathrm{Co}_{3} \mathrm{O}_{4}$ \\
\hline & {$[\mathrm{Cu}]$} & $\mathrm{CuO}$ & $\mathrm{Cu}^{\circ}$ & $\mathrm{Cu}^{\circ}$ & $\mathrm{Cu}^{\circ}$ \\
\hline & {$[\mathrm{Zn}]$} & $\mathrm{ZnO}$ & $\mathrm{ZnO}$ & $\mathrm{ZnO}$ & $\mathrm{ZnO}$ \\
\hline \multirow[t]{3}{*}{11 Co-IW } & [Co] & $\mathrm{Co}_{3} \mathrm{O}_{4}$ & * & * & * \\
\hline & {$[\mathrm{Cu}]$} & $\mathrm{CuO}$ & $\mathrm{Cu}^{\circ}$ & $\mathrm{Cu}^{\circ}$ & $\mathrm{Cu}^{\circ}$ \\
\hline & {$[\mathrm{Zn}]$} & $\mathrm{ZnO}$ & $\mathrm{ZnO}$ & $\mathrm{ZnO}$ & $\mathrm{ZnO}$ \\
\hline \multirow[t]{3}{*}{ 05Co-IW } & [Co] & $*$ & $*$ & $*$ & * \\
\hline & [Cu] & $\mathrm{CuO}$ & $\mathrm{Cu}^{\circ}$ & $\mathrm{Cu}^{\circ}$ & $\mathrm{Cu}^{\circ}$ \\
\hline & {$[\mathrm{Zn}]$} & $\mathrm{ZnO}$ & $\mathrm{ZnO}$ & $\mathrm{ZnO}$ & $\mathrm{ZnO}$ \\
\hline \multirow[t]{2}{*}{ 00Co-IW } & {$[\mathrm{Cu}]$} & $\mathrm{CuO}$ & $\mathrm{Cu}^{\circ}$ & $\mathrm{Cu}^{\circ}$ & $\mathrm{Cu}^{\circ}$ \\
\hline & {$[\mathrm{Zn}]$} & $\mathrm{ZnO}$ & $\mathrm{ZnO}$ & $\mathrm{ZnO}$ & $\mathrm{ZnO}$ \\
\hline
\end{tabular}

* No phase was detected.

treatments copper was completely reduced and the cobalt-containing phases could not be detected by XRD. The XRD spectra of post reaction samples in Figure $\mathrm{A} 1$ and $\mathrm{A} 2$ indicated the presence of $\mathrm{Co}_{3} \mathrm{O}_{4}$ particles in the $11 \mathrm{Co}-\mathrm{CP}$ samples but not in the 11Co-IW samples. A summary of the phases detected by XRD in each catalyst sample is given in Table 8 .

Comparison between the XRD spectra of 00Co-IW, 05Co-IW and 11Co-IW samples prior to reduction in Figure $A 5(x)$ and post reduction $A$ in Figure $A 5$ (y) indicated that no sintering of the $\mathrm{Cu}, \mathrm{CuO}$ or $\mathrm{ZnO}$ particles was caused by the addition of cobalt using the impregnation method. Comparisons between 
the XRD spectra of the reduced samples of 11Co-CP in Figure A6 (x) and 11CoIW in Figure A7 (x), as well as between the post reaction samples of 11Co-CP in Figure A6 (y) and 11Co-IW in Figure A7 (y) showed no significant differences in the particle size of $\mathrm{Cu}, \mathrm{CuO}$ and $\mathrm{ZnO}$ formed by different reduction treatments. Comparison between the XRD spectra of $11 \mathrm{Co}-\mathrm{CP}-\mathrm{O}$ in Figure $\mathrm{A} 1$ and $11 \mathrm{Co}-\mathrm{IW}-\mathrm{O}$ in Figure A2 indicated that the particle sizes of $\mathrm{Co}_{3} \mathrm{O}_{4}, \mathrm{CuO}$ and $\mathrm{ZnO}$ in $11 \mathrm{Co}-\mathrm{CP}-\mathrm{O}$ were all relatively smaller than those in $11 \mathrm{Co}-\mathrm{IW}-\mathrm{O}$. The fact that no $\mathrm{Co}_{3} \mathrm{O}_{4}$ was shown in the XRD spectrum of $05 \mathrm{Co}$ IW-O indicated that the average particle size of $\mathrm{CO}_{3} \mathrm{O}_{4}$ in $05 \mathrm{Co}-\mathrm{IW}-\mathrm{O}$ was significantly smaller than in 11Co-IW-O and 11Co-CP-O. Comparison between the XRD spectra of 11Co-CP-A in Figure A1 (a) and 11Co-IW-A in Figure A2 (a) indicated that the particle size of $\mathrm{Cu}^{\circ}$ was smaller in $11 \mathrm{Co}-\mathrm{CP}-\mathrm{A}$ than in $11 \mathrm{Co}-\mathrm{IW}-\mathrm{A}$ and the difference in the particle size of $\mathrm{ZnO}$ was not as significant as of $\mathrm{Cu}^{\circ}$.

4.1.1.4 X-Ray Photoelectron Spectroscopy Measurement. Figures 7 11 show the XPS Cu $2 p$ and Co $2 p$ spectra of the catalyst samples listed in Table 4. Table $\mathrm{B}$ in Appendix B lists $\mathrm{Cu} 2 p_{3 / 2}$ binding energy values, the $\mathrm{Cu}$ Auger energy (LMM) and the Auger parameter for $\mathrm{Cu}$ compounds, oxidized and reduced catalyst samples. The reduction extents of cobalt and copper on the surfaces of 11Co-CP-A and 11Co-CP-C obtained by curve fitting of the Co $2 p$ spectra (b) and (c) in Figure 11 are shown in Figure $C$ of Appendix $C$ and Table 9. The peak representative for $\mathrm{Co}^{\circ}$ in the XPS Co $2 p$ spectrum of 11Co-IW-A was too small to apply the curve fitting method. Also shown in Table 9 is the atomic ratio of $\mathrm{Co}^{\circ} / \mathrm{Cu}^{\circ}$ estimated using the peak area values from Figure $\mathrm{C}$. Some 


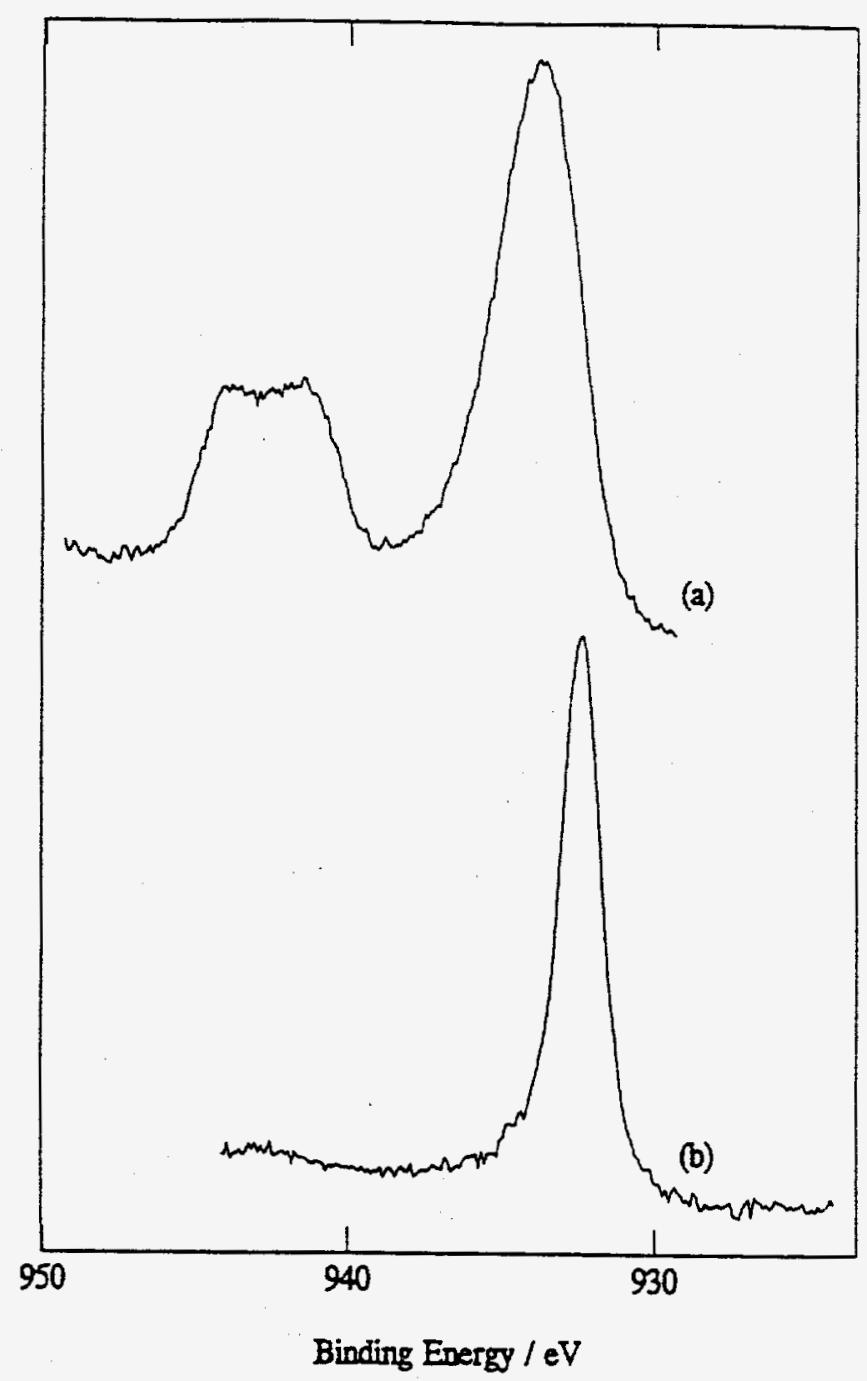

Figure 7 XPS Cu $2 p$ Spectra of (a) 00Co-IW-O and (b) 00Co-IW-A 


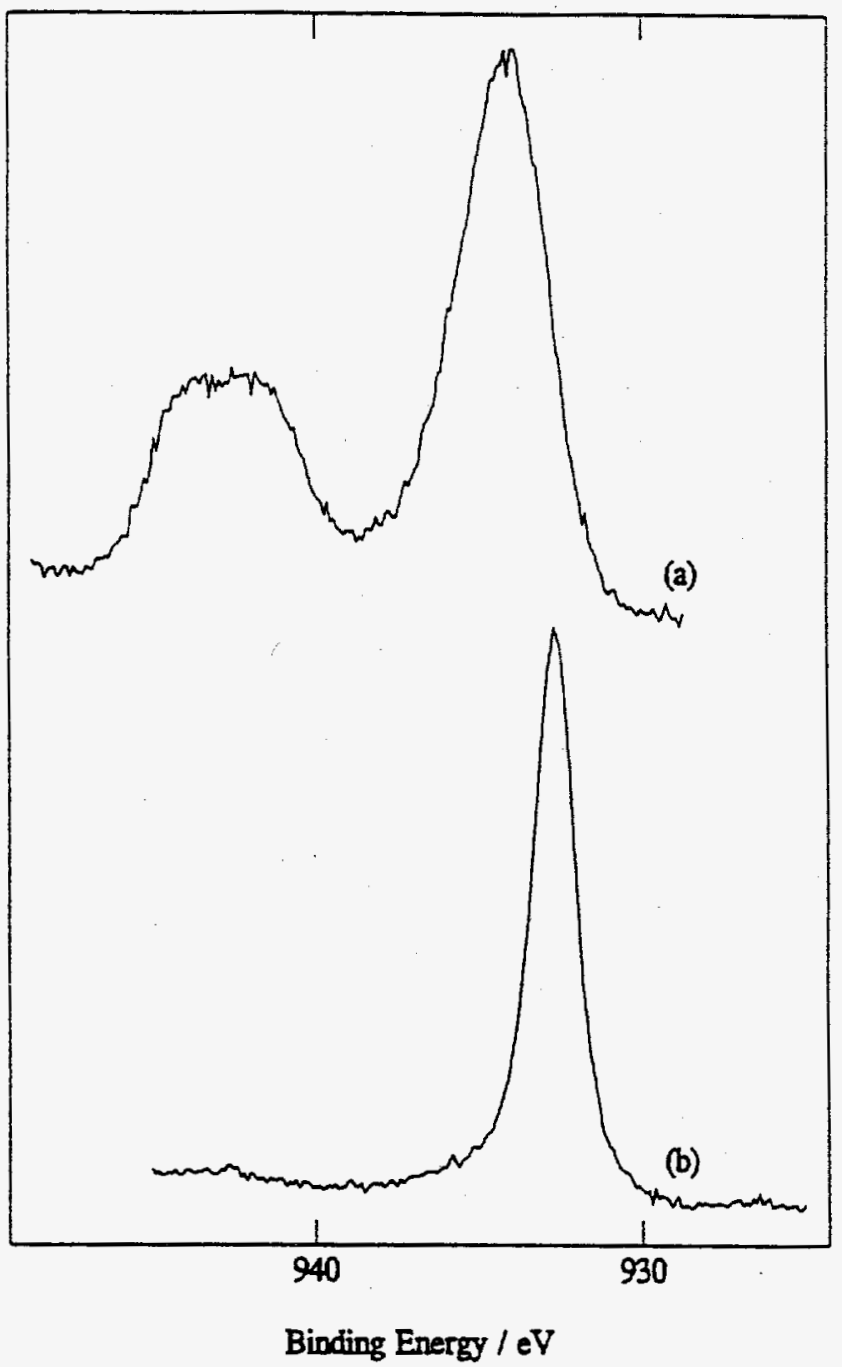

Figure 8 XPS Cu $2 p$ Spectra of (a) 11Co-IW-O and (b) 11Co-IW-A 


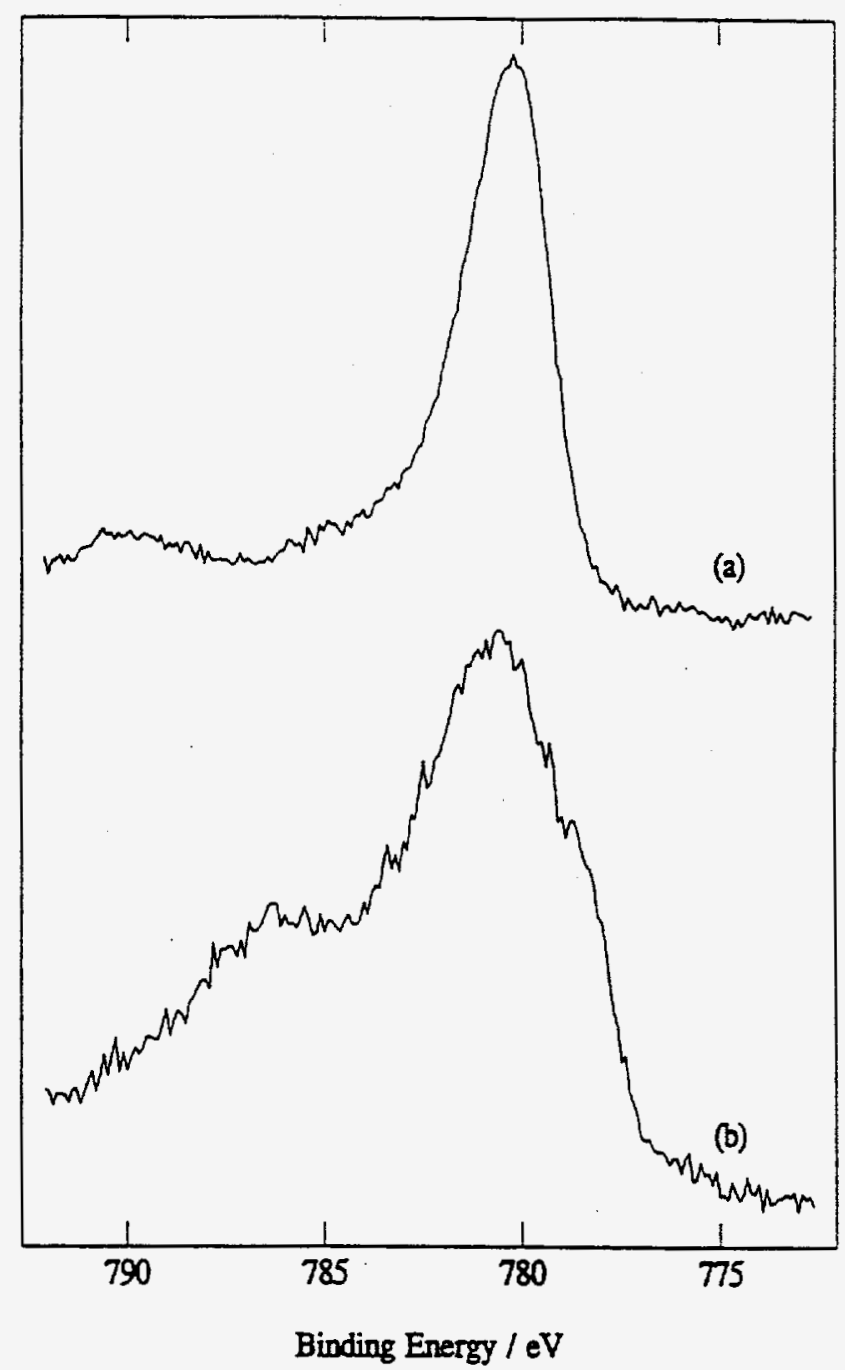

Figure 9 XPS Co $2 p$ Spectra of (a) 11Co-IW-O and (b) 11Co-IW-A 


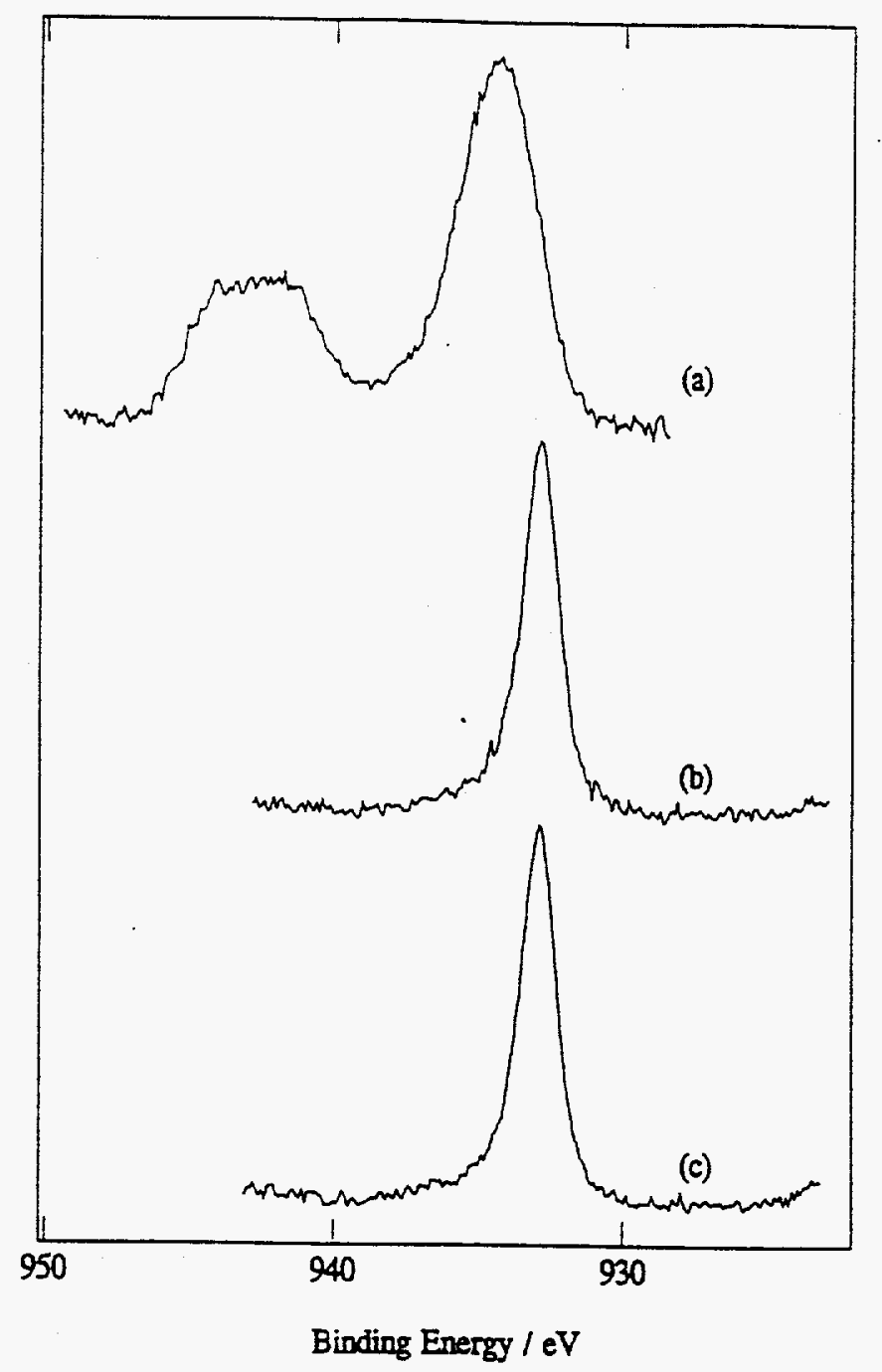

Figure 10 XPS Cu $2 p$ Spectra of (a) 11Co-CP-O, (b) 11Co-CP-A and (c) $11 \mathrm{Co}-\mathrm{CP}-\mathrm{C}$ 


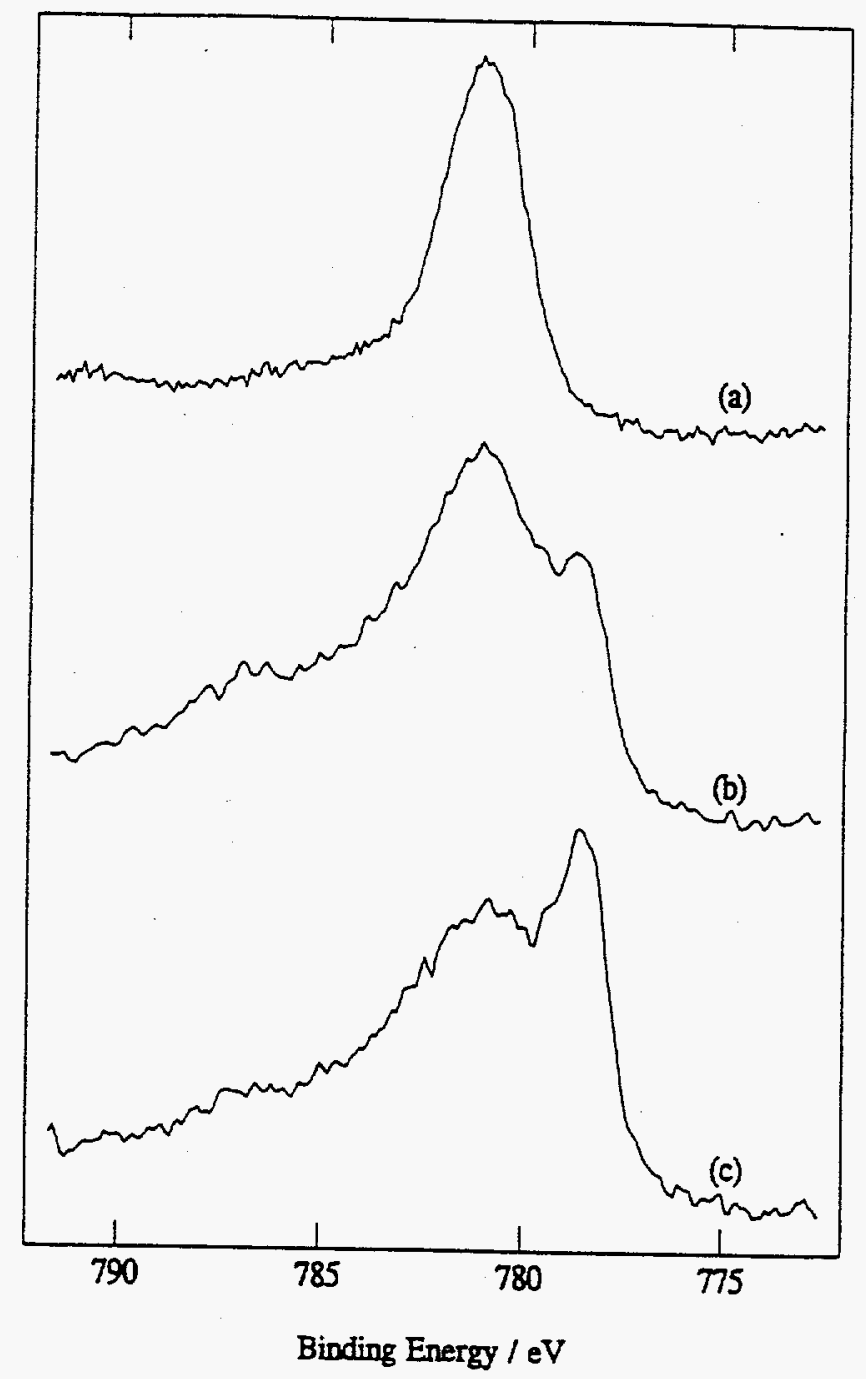

Figure 11 XPS Co $2 p$ Spectra of (a) 11Co-CP-O, (b) 11Co-CP-A and (c) $11 \mathrm{Co}-\mathrm{CP}-\mathrm{C}$ 
Table 9 Extent of Reduction of Cobalt and Copper and $\mathrm{Co}^{\circ} / \mathrm{Cu}^{\circ}$ Atomic Ratio on the Surfaces of $11 \mathrm{Co}-\mathrm{CP}-\mathrm{A}$ and $11 \mathrm{Co}-\mathrm{CP}-\mathrm{C}$

\begin{tabular}{cccc}
$\begin{array}{c}\text { Reduction } \\
\text { Condition }\end{array}$ & $\begin{array}{c}\text { Metal Reduction Extent } \\
\% \text { of } \mathrm{Co}^{\circ}\end{array}$ & $\begin{array}{c}\text { Atomic Ratio } \\
\text {. of } \mathrm{Cu}^{\circ}\end{array}$ & $\mathrm{Co}^{\circ} / \mathrm{Cu}^{\circ}$ \\
A & 28 & 100 & 0.54 \\
C & 48 & 100 & 1.02 \\
\hline
\end{tabular}

a: Refer to Table 2 for detailed discription.

b: $\%$ of $M^{\circ}=M^{\circ} /\left(M^{\circ}+\Sigma M^{m+}\right), m=1,2,3 . \%$ of $C_{0}$ was obtained from curve fitting of the $C o$ $2 p$ spectra of $11 \mathrm{Co}-\mathrm{CP}-\mathrm{A}$ and $11 \mathrm{Co}-\mathrm{CP}-\mathrm{C}$ (see Figure $\mathrm{C}$ in Appendix $\mathrm{C}$.)

c: Estimated using $\mathrm{Co}^{\circ} / \mathrm{Cu}^{\circ}=\left(\mathrm{PA}_{\mathrm{Co}^{\circ}} / \mathrm{S}_{\mathrm{Co}}\right) /\left(\mathrm{PA}_{\mathrm{Cu}^{\circ}} / \mathrm{S}_{\mathrm{Cu}}\right)$ in which the $\mathrm{PA}$, i.e. peak area, values were obtained from the XPS spectra and the values for $S_{C o}$ and $S_{C u}$ were taken from reference (102).

residue carbonate species left from catalyst preparation were detected from XPS measurement in $11 \mathrm{Co}-\mathrm{CP}$ samples but not in $00 \mathrm{Co}-\mathrm{IW}$ and $11 \mathrm{Co}-\mathrm{IW}$ samples.

As shown by spectra (a) in Figure 7,8 and 10, the XPS Cu $2 p$ spectra of the calcined samples all demonstrated the shape and the satellite structure that are representative for the presence of surface $\mathrm{Cu}^{2+}$ ions. As indicated in Table $\mathrm{B}$, the binding energy values of the $\mathrm{Cu} 2 p_{3 / 2}$ peaks in the spectra of the calcined samples were all about the same as the corresponding binding energy value obtained for $\mathrm{CuO}$. The XPS $\mathrm{Cu} 2 p$ spectra of the reduced samples shown in Figure 7, 8 and 10 showed no satellite structure but only the peak with the shape characteristic of $\mathrm{Cu}^{\circ}$. The position of these $\mathrm{Cu} 2 p$ peaks, as shown in Table $B$, was about the same as the value obtained from $\mathrm{Cu}^{\circ}$. This indicated that copper was present in the state of $\mathrm{CuO}$ on the surface of the catalyst 
samples prior to reduction treatment and was completely reduced on the surface of the catalyst samples receiving reduction treatment $A$ or $C$.

As shown by spectra (a) in Figure 9 and 11, the XPS Co $2 p$ spectra of the calcined samples all showed the Co $2 p$ peak shape and position $(\sim 781 \mathrm{eV})$ representative for $\mathrm{Co}_{3} \mathrm{O}_{4}$ phase indicating that cobalt was present in the state of $\mathrm{Co}_{3} \mathrm{O}_{4}$ on the surface of the catalyst samples prior to reduction. The XPS Co $2 p$ spectra of the reduced samples shown in Figure 9 and 11 all showed the peak shape resembling a mixture of $\mathrm{Co}^{\circ} / \mathrm{Co}^{2+} / \mathrm{Co}^{3+}$, indicating partial reduction of cobalt on the surface of the catalyst samples receiving reduction treatment $\mathrm{A}$ or $\mathrm{C}$. The peak at $778 \sim 779 \mathrm{eV}$ in the (b) and (c) spectra of Figure 9 and 11 was located at the position of $\mathrm{Co}^{\circ}$ and indicated the presence of $\mathrm{Co}^{\circ}$ on the surface. Comparison between the relative intensities of the cobalt metal peaks compared to the cobalt ion peaks in spectra (b) and (c) of Figure 9 and 11 indicated that the percentage of cobalt reduction was much lower on the surface of $11 \mathrm{Co}-\mathrm{CP}-\mathrm{A}$ than on $11 \mathrm{Co}-\mathrm{CP}-\mathrm{C}$ and the reduction percentage of cobalt on the surface of 11Co-IW-A was even lower than on the surface of 11Co-CP-A. The data obtained from curve fitting of the spectra in Figure 11 (see Figure $C$ and Table 9 ) indicated that $28 \%$ of cobalt was reduced on the surface of $11 \mathrm{Co}-\mathrm{CP}$ by reduction treatment $\mathrm{A}$ and $48 \%$ by reduction treatment C. It was also shown in Table 9 that the atomic ratio of $\mathrm{Co}^{\circ} / \mathrm{Cu}^{\circ}$ on the catalyst surface increased from 0.5 on $11 \mathrm{Co}-\mathrm{CP}-\mathrm{A}$ to 1.0 on $11 \mathrm{Co}-\mathrm{CP}-\mathrm{C}$. A similar comparison of the relative intensities of the peak representative for $\mathrm{Co}^{\circ}$ to the peak for $\mathrm{Cu}^{\circ}$ in the XPS spectra of $11 \mathrm{Co}-\mathrm{IW}-\mathrm{A}$ with the XPS spectra of $11 \mathrm{Co}$ $\mathrm{CP}-\mathrm{A}$ indicated that the local atomic ratio of $\mathrm{Co}^{\circ} / \mathrm{Cu}^{\circ}$ in $11 \mathrm{Co}-\mathrm{IW}-\mathrm{A}$ was lower than in $11 \mathrm{Co}-\mathrm{CP}-\mathrm{A}$. 


\subsubsection{Chemical Measurements}

4.1.2.1 Temperature Programmed Reduction. Figure 12 shows the TPR profiles of all four catalyst samples reduced by dilute $\mathrm{H}_{2}(5 \%)$ in $\mathrm{Ar}$ at atmospheric pressure (treatment $A$, refer to Table 2.) The integrated amounts of total $\mathrm{H}_{2}$-uptake from these TPR profiles were compared in Table 10 with. the $\mathrm{H}_{2}$-uptake calculated for complete reduction of $\mathrm{CuO}$ and $\mathrm{Co}_{3} \mathrm{O}_{4}$ in these samples.

Table 10 Estimation of the Reduction Extent of Cobalt Phase Based on the Results of TPR Experimenta

\begin{tabular}{ccccc}
\hline Catalyst & \multicolumn{2}{c}{$\begin{array}{c}\mathrm{H}_{2} \text {-Consumption } \\
(\mu \mathrm{mol} / \mathrm{mg} \text {-cat })\end{array}$} & $\begin{array}{c}\text { Co Reduction } \\
\end{array}$ \\
& $\begin{array}{c}\text { Measured } \mathrm{c} \\
\mathrm{CuO}+\mathrm{Co}_{3} \mathrm{O}_{4}\end{array}$ & $\begin{array}{c}\text { Calculated } \\
\text { CuO }\end{array}$ & $\mathrm{Co}_{3} \mathrm{O}_{4}$ & \\
& & & & \\
$00 \mathrm{Co}-\mathrm{IW}$ & $5.24 \pm 0.12$ & 5.24 & - & - \\
$05 \mathrm{Co}-\mathrm{IW}$ & $5.87 \pm 0.04$ & 5.10 & 0.85 & $91 \pm 5$ \\
$11 \mathrm{Co}-\mathrm{IW}$ & $5.83 \pm 0.01$ & 5.10 & 1.70 & $43 \pm 1$ \\
$11 \mathrm{Co}-\mathrm{CP}$ & $4.60 \pm 0.02$ & 3.60 & 2.40 & $42 \pm 1$ \\
\hline
\end{tabular}

a: Heating from $50^{\circ} \mathrm{C}$ to $500^{\circ} \mathrm{C}$ at $1^{\circ} \mathrm{C} / \mathrm{min}$ in dilute $\mathrm{H}_{2}(5 \%$ in $\mathrm{Ar}, 20 \mathrm{cc} / \mathrm{min})$ at $1 \mathrm{~atm}$ (Treatment A.)

b: Assuming $100 \%$ reduction of copper.

c: Error was determined by making repeated runs.

d: Assuming $100 \%$ reduction of copper and cobalt phases. The composition of these two phases was calculated considering the content of water measured by TGA experiment. 
The TPR profiles shown in Figure 12 demonstrated a shift of the major TPR peak towards higher temperature with the inclusion of increasing amounts of cobalt in the $\mathrm{CuO} / \mathrm{ZnO}$ based catalyst, i.e. the peak temperature of 00Co-IW < 05Co-IW < 11Co-IW < 11Co-CP (refer Table 1 for catalyst composition). All the major TPR peaks in Figure 12 were at temperatures below $250^{\circ} \mathrm{C}$. The data in Table 10 showed that reduction A resulted in $\sim 90 \%$ reduction of cobalt in $05 \mathrm{Co}-\mathrm{IW}$ and $~ 40 \%$ in $11 \mathrm{Co}-\mathrm{IW}$ and $11 \mathrm{Co}-\mathrm{CP}$.

The results of the other set of TPR and related testing experiments with $11 \mathrm{Co}-\mathrm{CP}, 11 \mathrm{Co}-\mathrm{IW}$ and $00 \mathrm{Co}-\mathrm{IW}$ performed on the reaction system using $\mathrm{H}_{2} \mathrm{O}$ detection by MS were outlined in Table 11. The spectra of $\mathrm{H}_{2} \mathrm{O}$ detection from each of the experiments listed in Table 11 (described in detail by Table D in Appendix D) were shown in Figure 13 15 and Figure D1 and D2 (in Appendix D). Due to the generally poor quantification performance of MS, the results were viewed qualitatively only.

Comparison between the TPR profiles of cobalt containing samples (11Co-CP and 11Co-IW) and non-cobalt sample (00Co-IW) obtained from reduction $A$ and $B$ indicated that reduction $B$ of cobalt containing samples resulted in TPR peaks much broader than those from reduction A (see Figure 13 and 14), while reduction B of non-cobalt sample resulted in a sharp TPR peak similar to the one from reduction A (see Figure 15). Comparison of the TPR profiles obtained from reduction $C$ with $A$ indicated that the low temperature peaks obtained from reduction $C$ were all shifted to lower temperatures (by $\sim 60^{\circ} \mathrm{C}$ with $11 \mathrm{Co}-\mathrm{CP}, \sim 30^{\circ} \mathrm{C}$ with $11 \mathrm{Co}-\mathrm{IW}$ and $\sim 40^{\circ} \mathrm{C}$ with $00 \mathrm{Co}-\mathrm{IW}$ ) with increased $\mathrm{H}_{2}$ partial pressure of the reducing gas. However, the intensity of the low temperature peak of $11 \mathrm{Co}-\mathrm{CP}$ from reduction $\mathrm{C}$ 


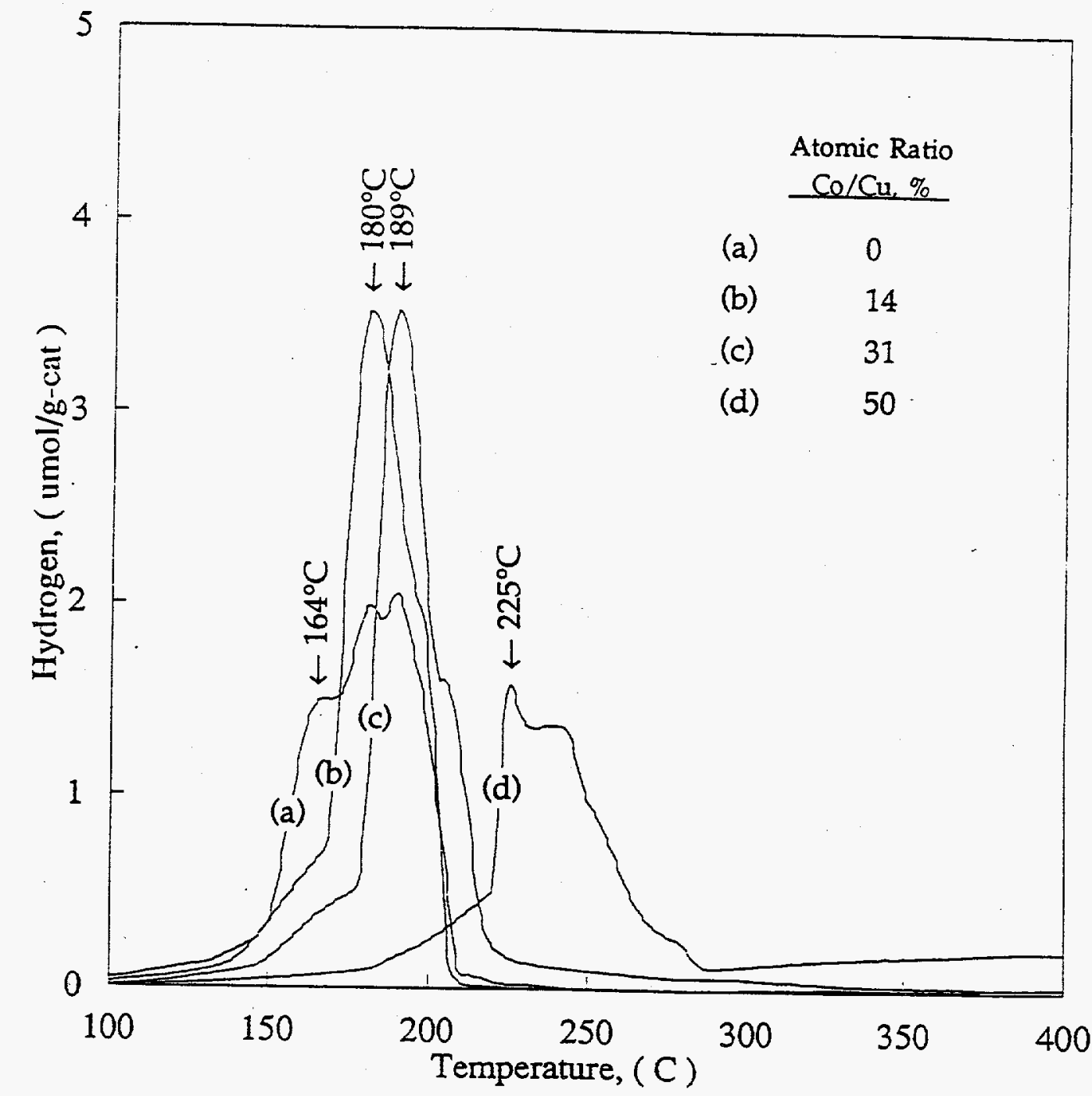

Figure 12 TPR Profiles of (a) 00Co-IW, (b) 05Co-IW, (c) $11 \mathrm{Co}-\mathrm{IW}$ and (d) $11 \mathrm{Co}-\mathrm{CP}$ Reduced in Dilute $\mathrm{H}_{2}(5 \%$ in $\mathrm{Ar}, 20 \mathrm{cc} / \mathrm{min})$ at Atmospheric Pressure (Treatment A) 
Table 11 Outline of the Results of the TPR and Related Testing Experiments Using $\mathrm{H}_{2} \mathrm{O}$ Detection by MS

\begin{tabular}{|c|c|c|c|c|c|c|c|}
\hline \multicolumn{5}{|c|}{ Treatments ${ }^{a}$} & \multicolumn{3}{|c|}{$\begin{array}{c}\text { Spectra of } \mathrm{H}_{2} \mathrm{O} \text { Detection } \\
\text { ( Figure \#) }\end{array}$} \\
\hline \multicolumn{2}{|c|}{ Describtor } & $\begin{array}{c}P \\
\text { (atm) }\end{array}$ & $\begin{array}{c}\mathrm{T} \\
\left({ }^{\circ} \mathrm{C}\right)\end{array}$ & $\begin{array}{c}\mathrm{H}_{2} \\
(\%)\end{array}$ & $11 \mathrm{Co}-\mathrm{CP}$ & $11 \mathrm{Co}-\mathrm{IW}$ & $00 \mathrm{Co}-\mathrm{IW}$ \\
\hline \multicolumn{8}{|c|}{ TPR: } \\
\hline A & & 1 & $34 \rightarrow 350$ & 5 & $13(a)$ & $14(a)$ & $15(a)$ \\
\hline B & & 35 & $34 \rightarrow 350$ & 5 & 13 (b) & 14 (b) & 15 (b) \\
\hline C & & 1 & $34 \rightarrow 350$ & 100 & $13(c)$ & $14(c)$ & $15(c)$ \\
\hline $\mathrm{D}$ & $=\begin{array}{c}\mathrm{A} \\
\Downarrow \\
\mathrm{B}\end{array}$ & $\sim$ & $\sim$ & $\sim$ & $\begin{array}{c}\sim \\
13(d)\end{array}$ & - & - \\
\hline $\mathrm{E}$ & $=\begin{array}{l}A \\
\Downarrow \\
C\end{array}$ & $\sim$ & $\sim$ & $\sim$ & $13(e)$ & - & - \\
\hline $\mathrm{F}$ & $=\begin{array}{r}\mathrm{C} \\
\Downarrow \\
\mathrm{B}\end{array}$ & $\sim$ & $\sim$ & $\sim$ & $\begin{array}{c}\sim \\
13(f)\end{array}$ & - & $\begin{array}{l}- \\
-\end{array}$ \\
\hline \multicolumn{8}{|c|}{ Testing: } \\
\hline \multirow[t]{2}{*}{ G } & $=\underset{\Downarrow}{G^{\prime}}$ & 1 & $34 \rightarrow 350$ & 0 & $\mathrm{D} 1\left(\mathrm{~g}^{\prime}\right)$ & $\mathrm{D} 2\left(\mathrm{~g}^{\prime}\right)$ & - \\
\hline & $G^{\prime \prime}$ & 1 & $350 \rightarrow 500$ & 0 & $\mathrm{D} 1\left(\mathrm{~g}^{\prime \prime}\right)$ & $\mathrm{D} 2\left(\mathrm{~g}^{\prime \prime}\right)$ & - \\
\hline $\mathrm{H}$ & $=\begin{array}{c}\mathrm{A} \\
\Downarrow \\
\mathrm{G}^{\prime \prime}\end{array}$ & $\sim$ & $\sim$ & $\sim$ & $\begin{array}{c}\sim \\
\text { D1 (h) }\end{array}$ & - & - \\
\hline \multirow[t]{3}{*}{ I } & $=\begin{array}{c}\mathrm{A} \\
\Downarrow \\
\mathrm{I}^{\prime} \\
\Downarrow\end{array}$ & $\underset{1 \rightarrow 35}{\sim}$ & $\begin{array}{r}\sim \\
290\end{array}$ & $\sim$ & $\begin{array}{c}\sim \\
\mathrm{D} 1\left(\mathrm{i}^{\prime}\right)\end{array}$ & - & - \\
\hline & $\begin{array}{l}\| \prime \\
I^{\prime \prime}\end{array}$ & 35 & $290 \rightarrow 350$ & 77 & $\mathrm{D} 1(\mathrm{i} ")$ & - & - \\
\hline & $\mathrm{G}^{\prime \prime}$ & $\sim$ & $\sim$ & $\sim$ & * & - & - \\
\hline
\end{tabular}

a : See Table $\mathrm{D}$ in Appendix $\mathrm{D}$ for detailed description of the conditions and procedures.

$\sim$ : Information is already given in the same table.

-: No experiment was performed.

*: No water was detected. 

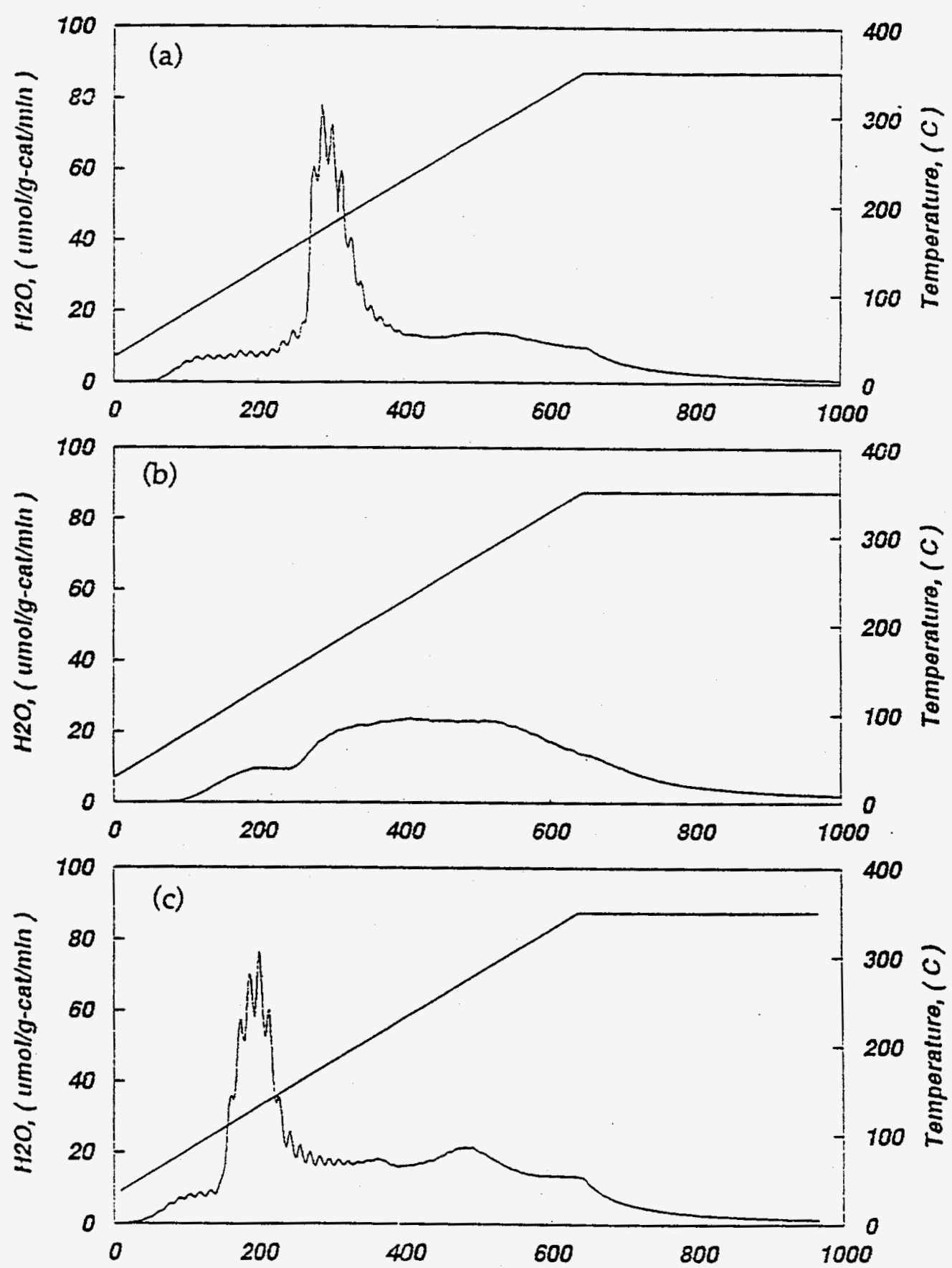

Time, ( $\min$ )

Figure $13(a-c)$ TPR Profiles of $11 \mathrm{Co}-\mathrm{CP}$ Reduced at Condition, (a) A, (b) B, and (c) C as Described in Table 11 \& D 

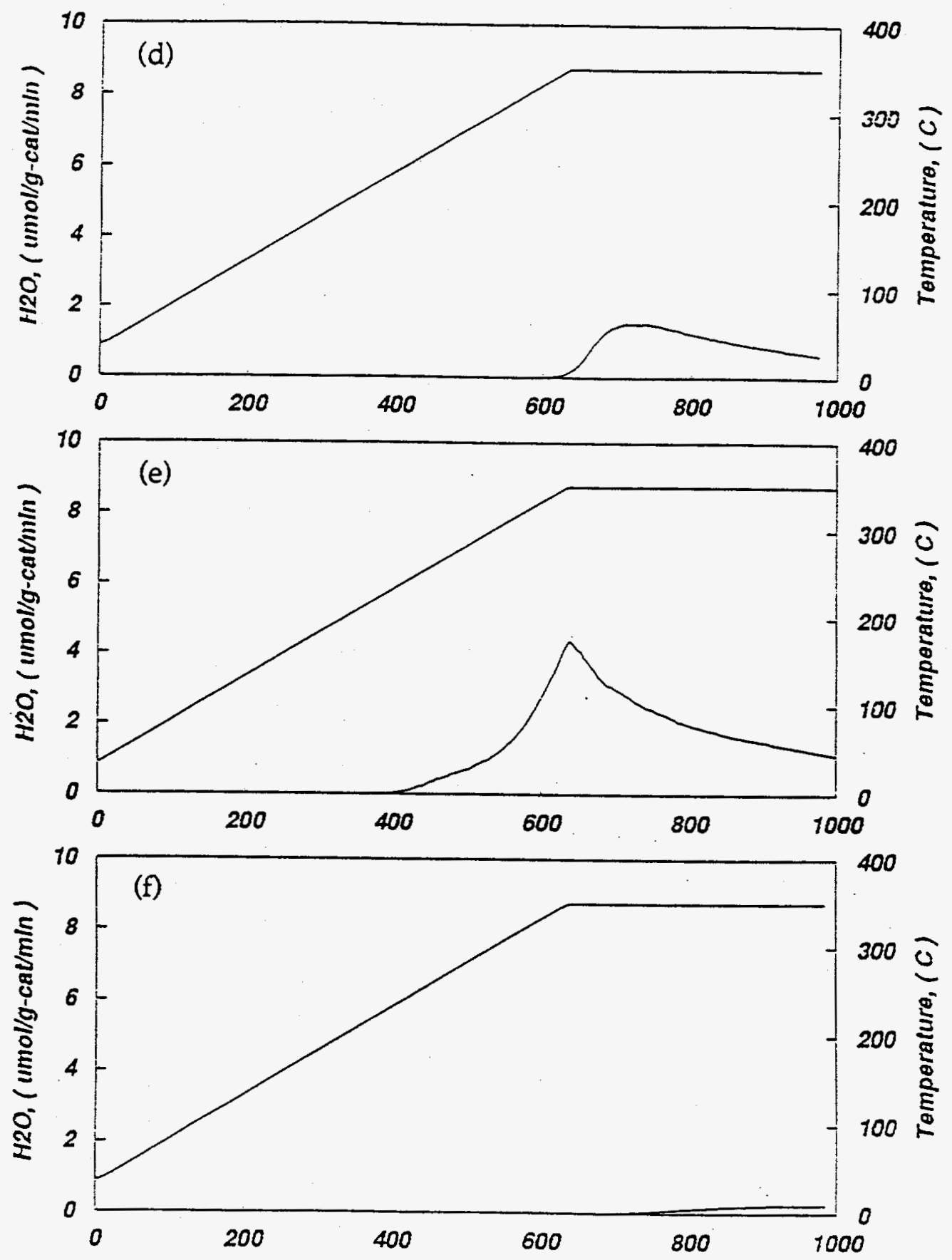

Time, ( $\min$ )

Figure $13(\mathrm{~d} \sim \mathrm{f})$ TPR Profiles of $11 \mathrm{Co}-\mathrm{CP}$ Reduced at Condition

(d) D, (e) E, and (f) F as Described in Table 11 and D 


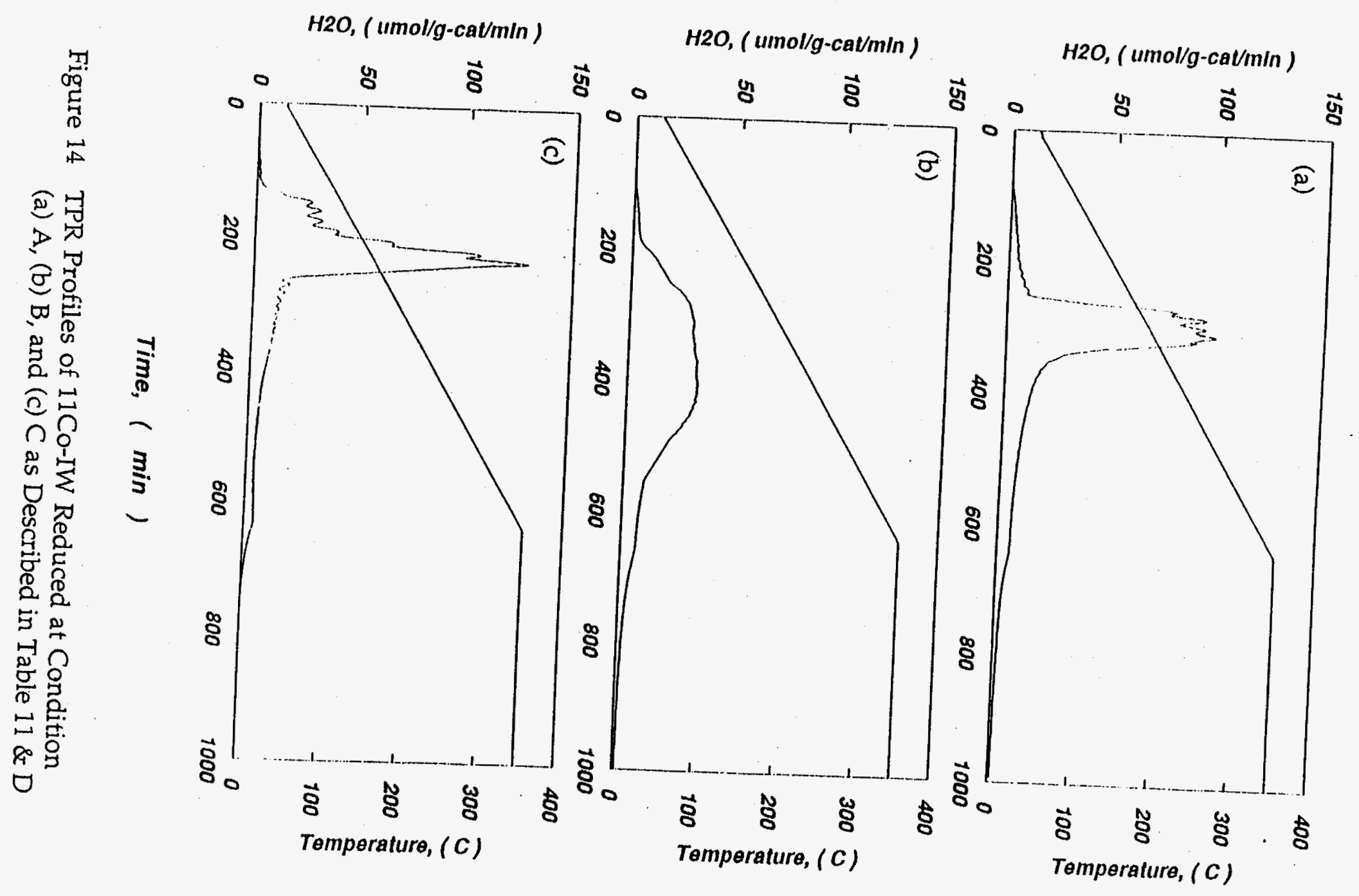



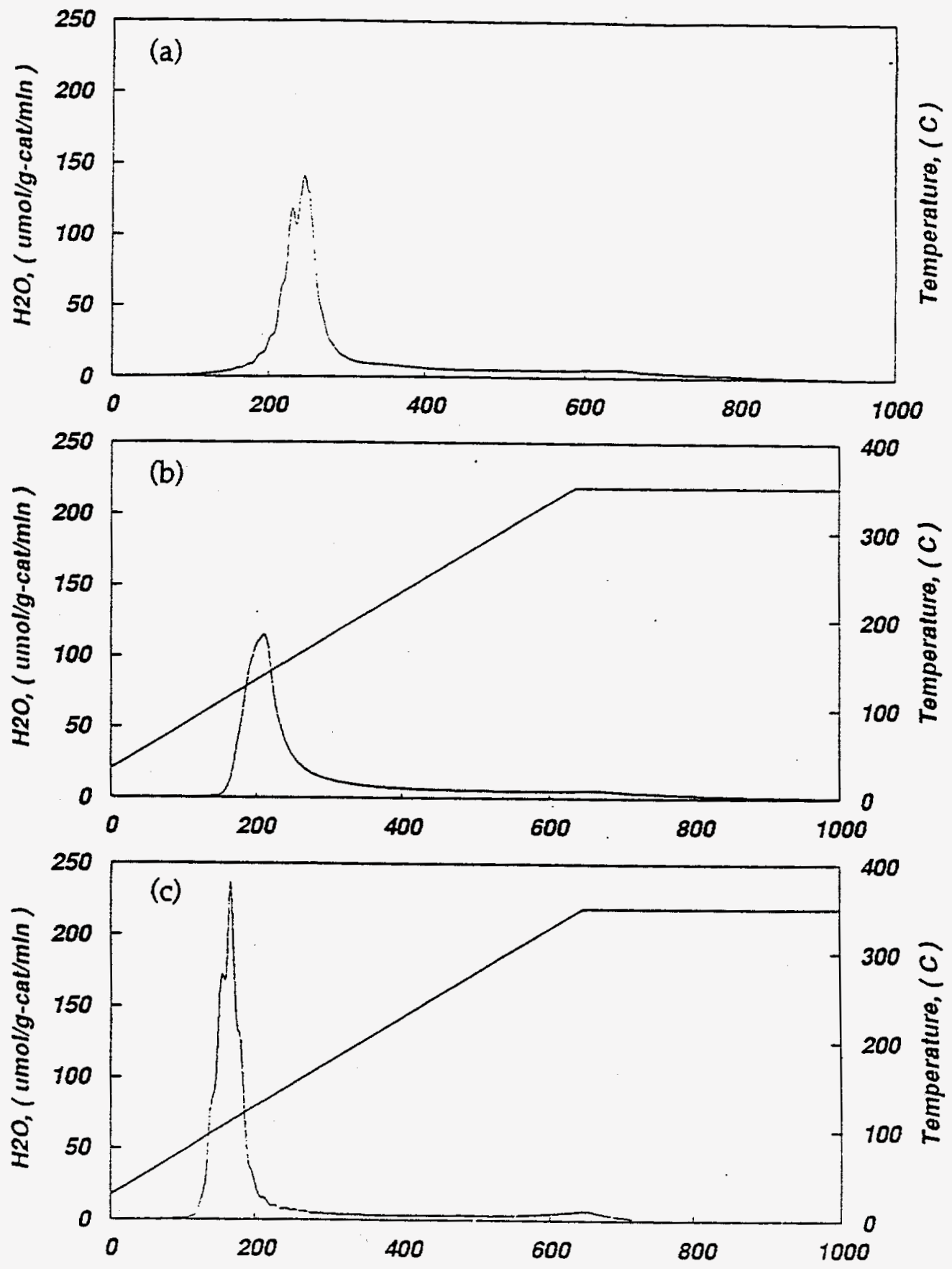

Time, ( $\min )$

Figure 15 TPR Profiles of 00Co-IW Reduced at Condition (a) A, (b) B, and (c) C as Described in Table 11 \& D 
remained the same as from reduction $A$ while the intensity of the low temperature peaks of both 00Co-IW and 11Co-IW from reduction $\mathrm{C}$ increased significantly. The TPR profile of $11 \mathrm{Co}-\mathrm{CP}$ obtained from reduction $\mathrm{C}$ demonstrated a high temperature peak more intense than the one from reduction $\mathrm{A}$, mainly located at $250 \sim 300^{\circ} \mathrm{C}$, which suggested a further sample reduction in $11 \mathrm{Co}-\mathrm{CP}-\mathrm{C}$.

The TPR profiles shown in Figure 13 (d) and 13 (e) demonstrated further detection of $\mathrm{H}_{2} \mathrm{O}$ from the reduction treatment $\mathrm{B}$ and $\mathrm{C}$ after treatment $\mathrm{A}$ for $11 \mathrm{Co}-\mathrm{CP}$. The $\mathrm{H}_{2} \mathrm{O}$ was detected mainly at temperatures higher than $290^{\circ} \mathrm{C}$, and the peak intensity of treatment $C$ after $A$ was higher than the one of treatment $B$ after $A$. It suggested that both treatment $B$ and $C$ caused a higher extent of reduction of $11 \mathrm{Co}-\mathrm{CP}$ than treatment $\mathrm{A}$. The further detection of $\mathrm{H}_{2} \mathrm{O}$ in experiment $\mathrm{F}$ from $B$ after $\mathrm{C}$, see Figure $13(\mathrm{f})$, was relatively insignificant, indicating that the treatment $\mathrm{C}$ of $11 \mathrm{Co}-\mathrm{CP}$ resulted in a reduction extent limit which treatment $B$ could hardly exceed.

Blank TPR runs indicated that the $\mathrm{H}_{2} \mathrm{O}$ presented in the catalysts prior to the TPR experiments was very small for both $11 \mathrm{Co}-\mathrm{IW}$ and $11 \mathrm{Co}-\mathrm{CP}$ (refer to Figure $\left.D 1 \& 2\left(g^{\prime}\right)\right)$. High temperature testing experiments indicated that little strongly adsorbed $\mathrm{H}_{2} \mathrm{O}$ was left in the catalyst samples after TPR runs (refer to Figure D1\&2 $\left.\left(g^{\prime \prime}\right)\right)$. This provided further evidence that an increased sample reduction extent in $11 \mathrm{Co}-\mathrm{CP}-\mathrm{C}$ caused the high temperature peak of $11 \mathrm{Co}-\mathrm{CP}$ $\mathrm{C}$ to be more intense than the one of $11 \mathrm{Co}-\mathrm{CP}-\mathrm{A}$ as well as the further $\mathrm{H}_{2} \mathrm{O}$ detection during the treatment $\mathrm{C}$ after $\mathrm{A}$ in experiment $\mathrm{E}$. The amounts of $\mathrm{H}_{2} \mathrm{O}$ detected from treatments $\mathrm{A}, \mathrm{B}$ and $\mathrm{C}$ for $11 \mathrm{Co}-\mathrm{CP}$ increased in the order $\mathrm{A}<\mathrm{B}<\mathrm{C}$, which indicated that the reduction extent of $11 \mathrm{Co}-\mathrm{CP}$ increased 
with the reduction treatments in the order of $\mathrm{A}<\mathrm{B}<\mathrm{C}$. In addition, increasing $\mathrm{H}_{2}$ partial pressure at $290^{\circ} \mathrm{C}$ (reaction temperature) after reduction treatment A did not cause significant further reduction of the sample but increasing temperature from $290^{\circ} \mathrm{C}$ to $350^{\circ} \mathrm{C}$ under high $\mathrm{H}_{2}$ partial pressure did (refer to Figure D1 $\left(i^{\prime}\right)$ ). This suggested that the reduction temperature was also a key factor in enhancing sample reduction. However, little difference in the total amounts of $\mathrm{H}_{2} \mathrm{O}$ detection was shown with 11Co-IW and 00Co-IW samples receiving treatments $A, B$ and $C$, demonstrating that the improvement in sample reduction extent with treatment $B$ or $C$ was not observed with the non-cobalt containing sample neither with the cobalt containing sample prepared by impregnation.

4.1.2.2 Temperature Programmed Desorption of $\mathrm{H}_{2}$. The results of $\mathrm{H}_{2}$-TPD experiments were summarized in Table 12. As listed in Table 12, the TPD spectra of the reduced samples were presented in Figure 16 19.

The $\mathrm{H}_{2}$-TPD spectra of 00Co-IW-A and 00Co-IW-C shown in Figure 16 demonstrated similar profiles with a low temperature maximum at $\sim 170^{\circ} \mathrm{C}$ and a high temperature maximum at $\sim 450^{\circ} \mathrm{C}$, indicating similar surface distribution of copper metal sites.

The TPD spectra of $11 \mathrm{Co}-\mathrm{IW}-\mathrm{A}$ and $11 \mathrm{Co}-\mathrm{IW}-\mathrm{C}$ shown in Figure 17 demonstrated the poorly resolved profiles with a low temperature maximum at $\sim 150^{\circ} \mathrm{C}$ and a high temperature maximum at $\sim 450^{\circ} \mathrm{C}$. However, the intensity of the low temperature peak of $11 \mathrm{Co}-\mathrm{IW}-\mathrm{C}$ was much higher than the one of 11Co-IW-A while the intensity of the high temperature peaks were about the same and hence the total $\mathrm{H}_{2}$-uptake on 11Co-IW-C was significantly 
Table 12 Results of $\mathrm{H}_{2}$-TPD Experiments ${ }^{\mathrm{a}}$

\begin{tabular}{|c|c|c|c|c|c|}
\hline \multirow[t]{2}{*}{ Catalyst } & \multirow[t]{2}{*}{ Reduction $^{b}$} & \multirow{2}{*}{$\begin{array}{c}\text { Figure } \\
\# \\
\end{array}$} & \multicolumn{3}{|c|}{$\mathrm{H}_{2}$ Coverage } \\
\hline & & & $\begin{array}{l}\mu \mathrm{mol}-\mathrm{H} \\
\angle \mathrm{mg}-\mathrm{cat}\end{array}$ & $\begin{array}{c}\mu \mathrm{mol}-\mathrm{H} \\
\mathcal{L} \mathrm{mg}-\mathrm{Cu} \& \mathrm{Co}_{0}\end{array}$ & $\begin{array}{c}\mu \mathrm{mol}-\mathrm{H}^{\mathrm{c}} \\
\angle \mathrm{mg}-\mathrm{Co}^{\circ} \& \mathrm{C} u^{\circ}\end{array}$ \\
\hline \multirow[t]{2}{*}{ 00Co-IW } & $A$ & $16(a)$ & 0.40 & 0.9 & 0.9 \\
\hline & C & 16 (b) & 0.46 & 1.0 & 1.0 \\
\hline \multirow[t]{2}{*}{ 11Co-IW } & A & 17 (a) & 0.38 & 0.8 & 0.9 \\
\hline & $C$ & $17(\mathrm{~b})$ & 0.72 & 1.5 & 1.7 \\
\hline \multirow[t]{2}{*}{$11 \mathrm{Co}-\mathrm{CP}$} & A & $18(a)$ & 0.56 & 1.7 & 2.0 \\
\hline & $C$ & 18 (b) & 0.58 & 1.7 & 2.1 \\
\hline $20 \mathrm{Co} / \mathrm{SiO}_{2}{ }^{\mathrm{d}}$ & C & 19 & 0.15 & 0.8 & - \\
\hline
\end{tabular}

a: After reduction treatment at $350^{\circ} \mathrm{C}$, the sample $(\sim 100 \mathrm{mg})$ was cooled in the reduction gas stream to $50^{\circ} \mathrm{C}$ at which the gas phase $\mathrm{H}_{2}$ was flushed away with $\mathrm{Ar}(50 \mathrm{cc} / \mathrm{min})$. $\mathrm{H}_{2}$-TPD was then started from $50^{\circ} \mathrm{C}$ to $500^{\circ} \mathrm{C}$ at $20^{\circ} \mathrm{C} / \mathrm{min}$ in $\mathrm{Ar}(50 \mathrm{cc} / \mathrm{min})$.

b: $A$ and $C$ are equivalent to the reduction treatments listed in Table 2.

c: Assuming complete reduction of copper in all samples, and applying the data of cobalt reduction extent in Table 10 for the amounts of $\mathrm{Co}^{\circ}$ in $11 \mathrm{Co}-\mathrm{IW}-\mathrm{A}$ and $11 \mathrm{Co}-\mathrm{CP}-\mathrm{A}$.

d: A catalyst sample prepared by incipient wetness impregnation method and used to check the TPD peak position contributed by cobalt metal surface alone.

-: No experimental data for cobalt reduction extent. 

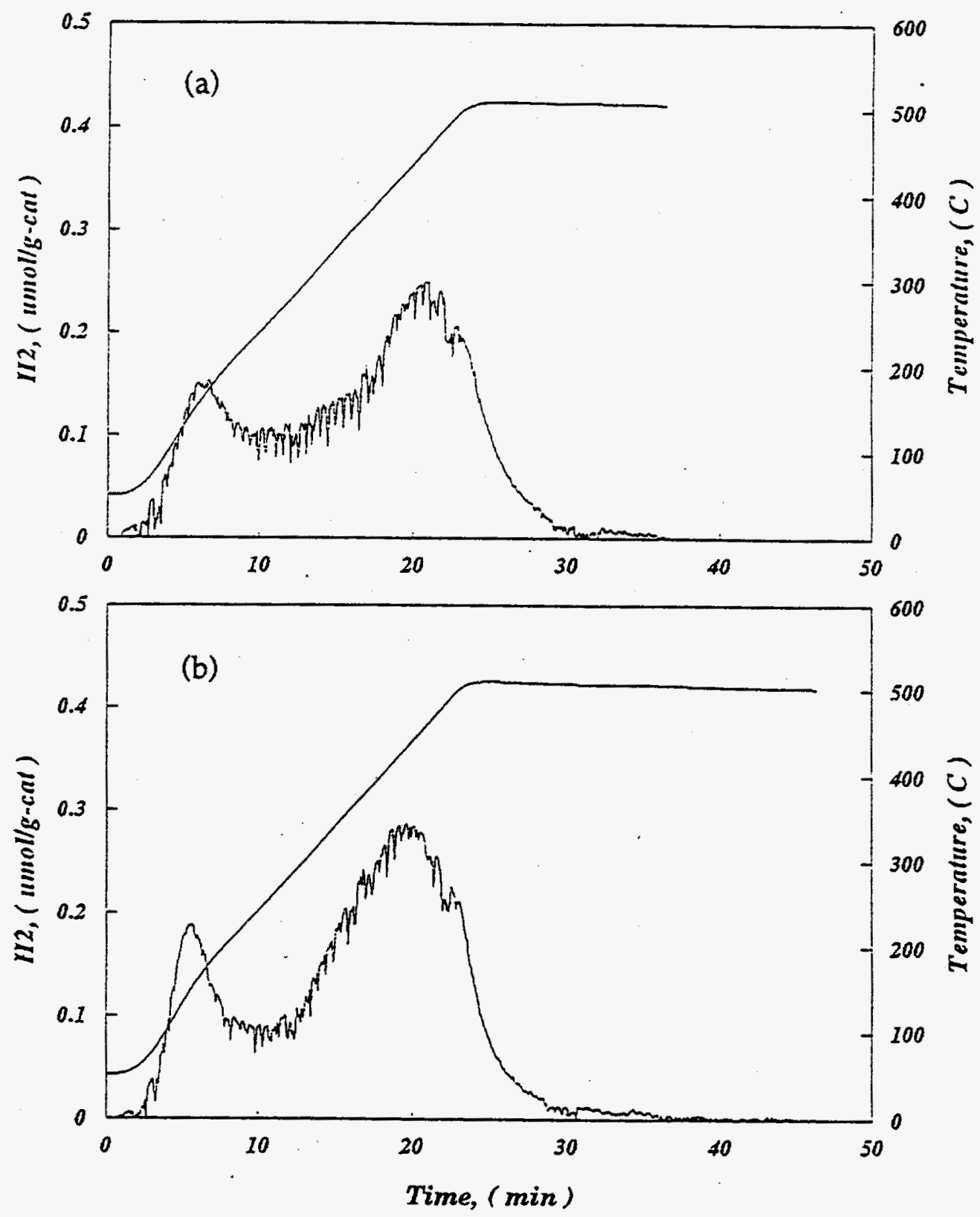

Figure 16 TPD Profiles of 00Co-IW Samples Reduced at $1 \mathrm{~atm}$, (a) in $5 \% \mathrm{H}_{2}$ (in $\mathrm{Ar}$ ), and (b) in $100 \% \mathrm{H}_{2}$ 

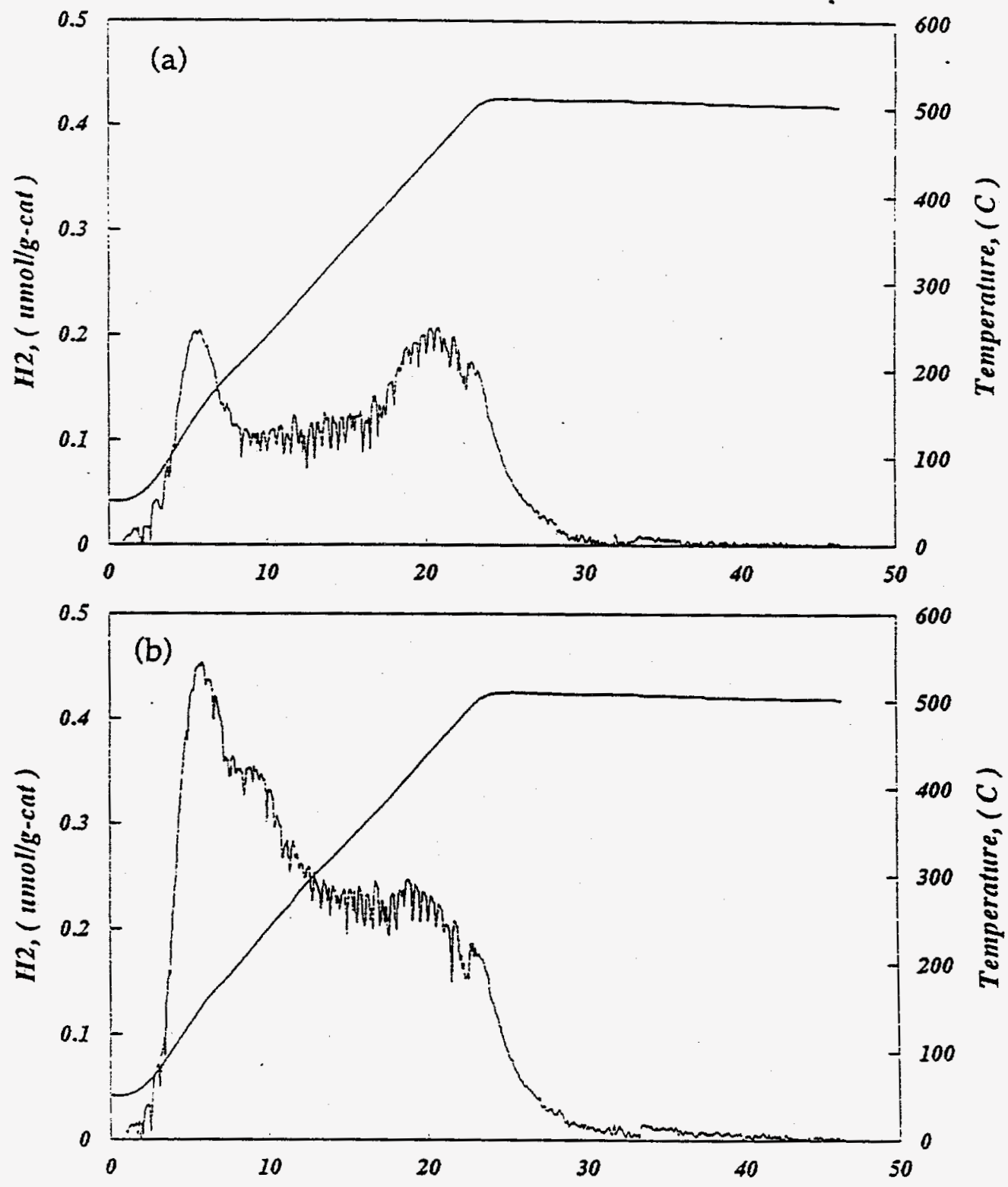

Time, (min)

Figure 17 TPD Profiles of 11Co-IW Samples Reduced at $1 \mathrm{~atm}$, (a) in $5 \% \mathrm{H}_{2}$ (in $\mathrm{Ar}$ ), and (b) in $100 \% \mathrm{H}_{2}$ 

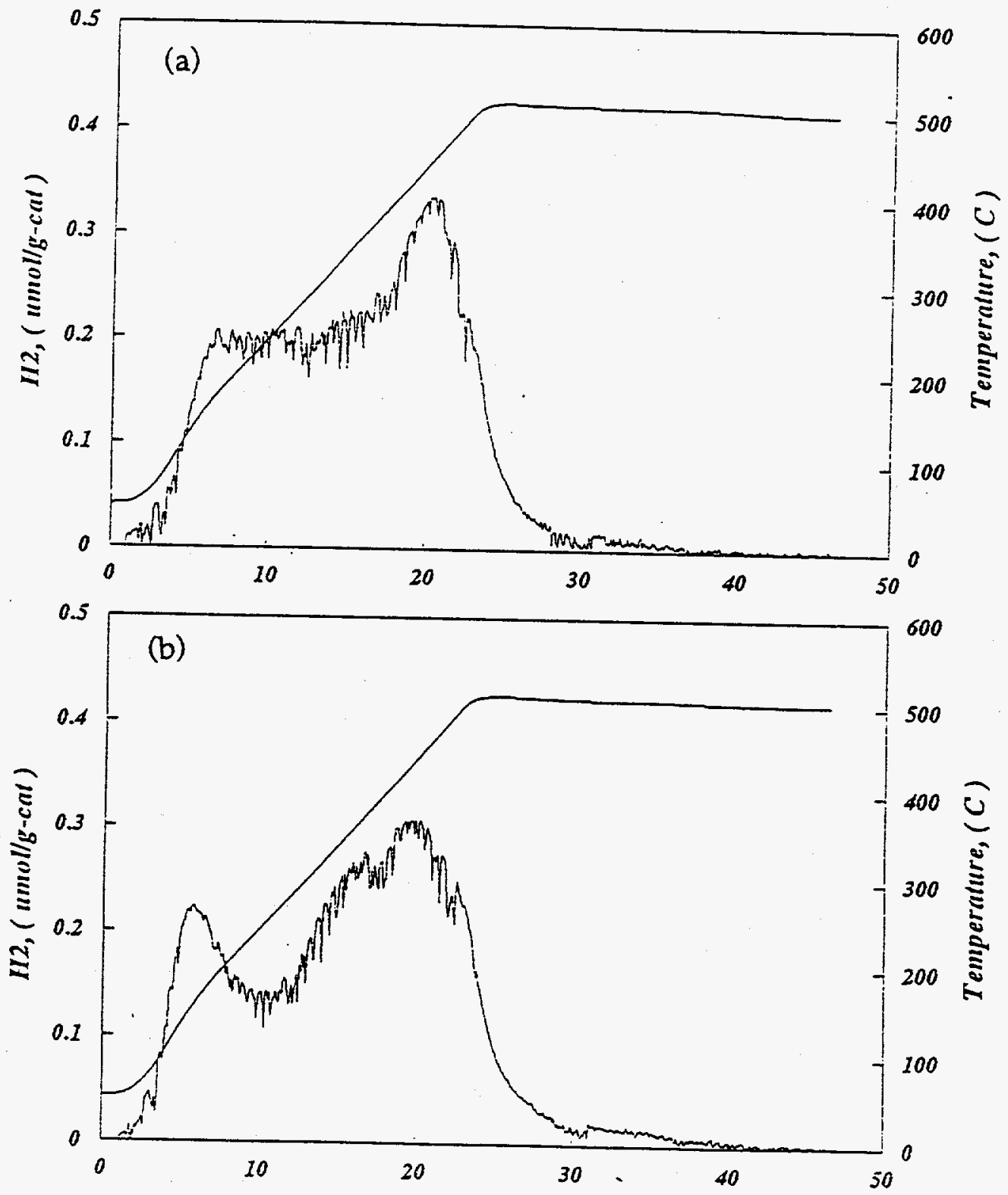

Time, $(\min )$

Figure 18 TPD Profiles of 11Co-CP Samples Reduced at $1 \mathrm{~atm}$, (a) in $5 \% \mathrm{H}_{2}$ (in $\mathrm{Ar}$ ), and (b) in $100 \% \mathrm{H}_{2}$ 


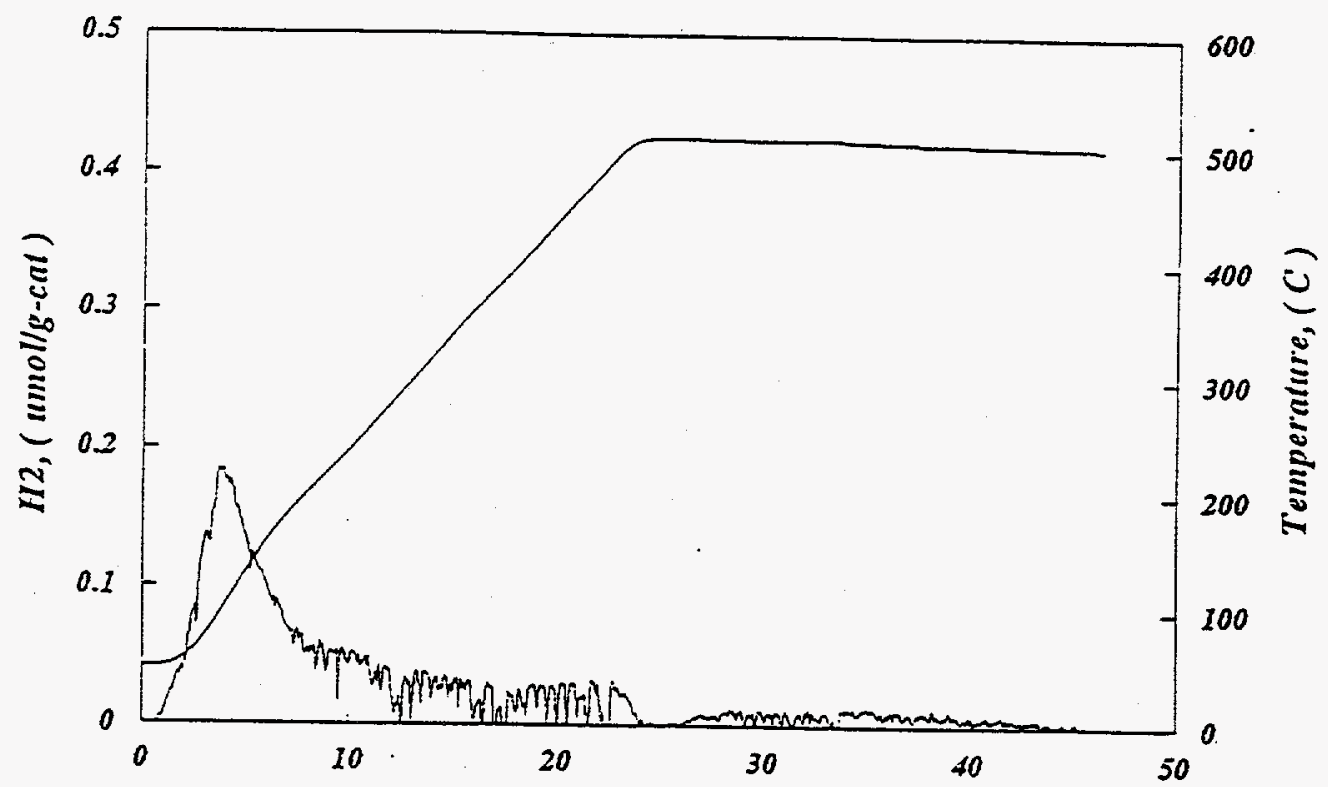

Time, ( $\min )$

Figure 19 TPD Profiles of $\mathrm{Co}(20 \%) / \mathrm{SiO}_{2}$ Sample Reduced at 1 atm in $100 \% \mathrm{H}_{2}$ 
higher than on 11Co-IW-A. Compared with the spectrum of $00 \mathrm{Co}-\mathrm{IW}-\mathrm{A}$, the spectrum of 11Co-IW-A showed higher intensity in the low temperature peak and lower intensity in the high temperature peak, while the total $\mathrm{H}_{2}$-uptake on 11Co-IW-A was about the same as on 00Co-IW-A.

The TPD spectra of $11 \mathrm{Co}-\mathrm{CP}-\mathrm{A}$ and $11 \mathrm{Co}-\mathrm{CP}-\mathrm{C}$ shown in Figure 18 demonstrated similar poorly resolved profiles with a low temperature maximum at $-170^{\circ} \mathrm{C}$ and a high temperature maximum at $\sim 450^{\circ} \mathrm{C}$. The intensity of the low temperature peak of $11 \mathrm{Co}-\mathrm{CP}-\mathrm{C}$ was slightly higher than the one of $11 \mathrm{Co}-\mathrm{CP}-\mathrm{A}$ and the intensity of the high temperature peak of $11 \mathrm{Co}$ $\mathrm{CP}-\mathrm{C}$ was slightly lower than the one of $11 \mathrm{Co}-\mathrm{CP}-\mathrm{A}$, while the total $\mathrm{H}_{2}$-uptake on $11 \mathrm{Co}-\mathrm{CP}-\mathrm{C}$, as shown in Table 12 , was almost the same as on $11 \mathrm{Co}-\mathrm{CP}-\mathrm{C}$. It was also shown that the $\mathrm{H}_{2}$-uptake on $11 \mathrm{Co}-\mathrm{CP}-\mathrm{A}$ was higher than on $11 \mathrm{Co}-$ IW-A and 00Co-IW-A.

As shown in Figure 19, the TPD spectrum of $20 \mathrm{Co} / \mathrm{SiO}_{2}-\mathrm{A}$, a sample used to test the $\mathrm{H}_{2}$-TPD peak location due to $\mathrm{Co}^{\circ}$, showed a single low temperature maximum at $100^{\circ} \mathrm{C}$ with a tailing ranging upto $500^{\circ} \mathrm{C}$. Considering the poorly resolved and widely spread $\mathrm{H}_{2}$-TPD profiles obtained from 00Co-IW as well as from $11 \mathrm{Co}-\mathrm{IW}$ and $11 \mathrm{Co}-\mathrm{CP}$, it indicated that on a surface of $\mathrm{Co}-\mathrm{Cu}$ based catalyst the $\mathrm{H}_{2}$-TPD peak from $\mathrm{Co}^{\circ}$ would overlap with the peak(s) from $\mathrm{Cu}^{\circ}$ but would mainly show up in the low-temperature-peak range representing the weak- $\mathrm{H}_{2}$-adsorption sites. 


\subsection{Discussion}

\subsubsection{Physical Measurements}

4.2.1.1 Effect of Cobalt-Inclusion in $\mathrm{Cu} / \mathrm{ZnO}$. The slight difference observed in BET surface area of the samples prior to and post cobalt-addition by impregnation as well as post reduction/reaction suggested that no particle sintering was caused by the addition of cobalt to $\mathrm{CuO} / \mathrm{ZnO} / \mathrm{Al}_{2} \mathrm{O}_{3}$ in either the un-reduced or the reduced catalyst samples. This was supported by the $X R D$ result shown in Figure $A 5$ indicating that no sintering in the crystallized particle size of $\mathrm{Cu}, \mathrm{CuO}$ or $\mathrm{ZnO}$ was caused by the addition of cobalt. Any significant differences in either adsorptive or catalytic properties between the non-cobalt and cobalt-containing samples would be due to the kind of change more subtle than a bulk change such as sample sintering.

\subsubsection{Chemical and Physical States of Cobalt and Copper. The results of XRD} and XPS measurements consistently indicated that copper was present in the state of $\mathrm{CuO}$ with cobalt in $\mathrm{CO}_{3} \mathrm{O}_{4}$ in all the catalyst samples prior to reduction and that copper was completely reduced to $\mathrm{Cu}^{\circ}$ in all the samples after any of the reduction treatments. As indicated by BET and XRD results, the particle sizes of $\mathrm{CuO}$ and $\mathrm{ZnO}$ were similar in the pre-reduction samples of 00Co-IW, $05 \mathrm{Co}-\mathrm{IW}$ and $11 \mathrm{Co}-\mathrm{IW}$, but relatively larger than in those of $11 \mathrm{Co}-\mathrm{CP}$. The $X R D$ results indicated that the particle sizes of $\mathrm{Co}_{3} \mathrm{O}_{4}$ in the pre-reduction samples were in the order of $11 \mathrm{Co}-\mathrm{IW}-\mathrm{O}>11 \mathrm{Co}-\mathrm{CP}-\mathrm{O}>05 \mathrm{Co}-\mathrm{IW}-\mathrm{O}$, and the particle size of $\mathrm{Cu}^{\circ}$ in $11 \mathrm{Co}-\mathrm{IW}-\mathrm{A}$ was about the same as in 05Co-IW-A as well 
as in $11 \mathrm{Co}-\mathrm{IW}-\mathrm{B}$ and $11 \mathrm{Co}-\mathrm{IW}-\mathrm{C}$ but larger than in $11 \mathrm{Co}-\mathrm{CP}-\mathrm{A}$ which was the same as in 11Co-CP-B and 11Co-CP-C.

Since the XPS results indicated that cobalt was partially reduced on the surface after either treatment $\mathrm{A}$ or $\mathrm{C}$, the disappearance of $\mathrm{Co}_{3} \mathrm{O}_{4}$ peaks in the XRD spectra of reduced cobalt-containing samples could be mainly due to the partial reduction of the $\mathrm{CO}_{3} \mathrm{O}_{4}$ particles which divided the particles of cobaltcontaining phases into the sizes too small for XRD detection. The reappearance of the $\mathrm{Co}_{3} \mathrm{O}_{4}$ peaks in the XRD spectra of $11 \mathrm{Co}-\mathrm{CP}$ samples post $\mathrm{CO}$ hydrogenation reaction could be due to either re-oxidation of the reduced cobalt or agglomerization of the $\mathrm{CO}_{3} \mathrm{O}_{4}$ particles. The fact that no cobaltcontaining phase was detected by XRD in the 11Co-IW samples post reaction could be due to either less re-oxidation of the reduced cobalt or less agglomerization of the $\mathrm{Co}_{3} \mathrm{O}_{4}$ particles.

An important point revealed by the XPS results is that the percentage of cobalt reduction to $\mathrm{Co}^{\circ}$ as well as the local atomic ratio of $\mathrm{Co}^{\circ} / \mathrm{Cu}^{\circ}$ on the catalyst surface increased significantly in the order of 11Co-IW-A $<11 \mathrm{Co}-\mathrm{CP}-\mathrm{A}$ $<11 \mathrm{Co}-\mathrm{CP}-\mathrm{C}$. The fact that different reduction treatments did not cause any significant difference between the XRD spectra of reduced samples, which did not showed cobalt-containing phases, indicated that the reduction of cobalt, either to low or high extent, did not form large $\mathrm{Co}^{\circ}$ particles with average diameter larger than $5 \mathrm{~nm}$ in any of the reduced catalyst samples and had no significant effect on the particle size of $\mathrm{Cu}^{\circ}$ as well as $\mathrm{ZnO}$. In other words, it indicated that in any of the reduced samples both $\mathrm{Co}^{\circ}$ and $\mathrm{Co}_{3} \mathrm{O}_{4}$ particles were finely dispersed on the surface of $\mathrm{Cu} / \mathrm{ZnO}$ without affecting the bulk structure of $\mathrm{Cu} / \mathrm{ZnO}$. Therefore, the surface contact between $\mathrm{Co}^{\circ}$ and $\mathrm{Cu}^{\circ}$ is 
suggested to be greater in $11 \mathrm{Co}-\mathrm{CP}-\mathrm{C}$ than in $11 \mathrm{Co}-\mathrm{CP}-\mathrm{A}$ and than in $11 \mathrm{Co}-\mathrm{IW}-$ A.

\subsubsection{Chemical Measurements}

4.2.2.1 Extent of Reduction of Cobalt. An important point revealed by the TPR measurements was that the extent of reduction of cobalt in each catalyst sample could be varied with different reduction treatments, different amounts of cobalt relative to the amount of copper, and different catalyst preparation methods.

Since XRD and XPS measurements indicated that copper was completely reduced in all the samples receiving any of the reduction treatments, all evidences of further sample reduction provided by TPR experiments could be attributed to further reduction of cobalt. The trends of the variations in cobalt reduction extent detected by both TPR and XPS measurements are compared in Table 13. Knowing that XPS measurement detects the top layers of the catalyst surface and TPR measurement probes the bulk properties of the catalyst, it is not surprising to observe different values of cobalt reduction extent with the same sample by the two different techniques. In fact, it could help understand the interaction of $\mathrm{Co}$ with $\mathrm{Cu}$ and distribution of $\mathrm{Co}$ in the catalyst, which is discussed in the following sections.

4.2.2.2 Interaction between Cobalt and Copper. Interaction between cobalt and copper has been proposed as a key factor in the selective synthesis of $\mathrm{C}_{2}+$ alcohols from $\mathrm{CO} / \mathrm{H}_{2}$ over $\mathrm{Co}-\mathrm{Cu}$ based catalysts $(6,40,45-50,97,98)$. Different 
Table 13 Variation in Reduction Extent of Cobalt in Different Samples

\begin{tabular}{|c|c|c|}
\hline Variable & Technique & Trend in Cobalt Reduction Extent \\
\hline . & & $\left(\mathrm{Co}^{\circ} / \mathrm{Co}, \%\right)$ \\
\hline Cu:Co Ratio: & TPR1a (bulk) & 05Co-IW-A $(91 \%)>11$ Co-IW-A $(43 \%)$ \\
\hline \multirow[t]{2}{*}{ Preparation Method: } & TPR1a (bulk) & $11 \mathrm{Co}-\mathrm{CP}-\mathrm{A}(42 \%) \approx 11 \mathrm{Co}-\mathrm{IW}-\mathrm{A}(43 \%)$ \\
\hline & XPS (surface) & $11 \mathrm{Co}-\mathrm{CP}-\mathrm{A}(28 \%)>11 \mathrm{Co}-\mathrm{IW}-\mathrm{A}$ \\
\hline \multirow[t]{4}{*}{ Reduction Treatment: } & TPR $2^{b}$ (bulk) & $11 \mathrm{Co}-\mathrm{CP}-\mathrm{C}>11 \mathrm{Co}-\mathrm{CP}-\mathrm{B}>11 \mathrm{Co}-\mathrm{CP}-\mathrm{A}$ \\
\hline & & $11 \mathrm{Co}-\mathrm{IW}-\mathrm{C} \approx 11 \mathrm{Co}-\mathrm{IW}-\mathrm{B} \approx 11 \mathrm{Co}-\mathrm{IW}-\mathrm{A}$ \\
\hline & XPS (surface) & $11 \mathrm{Co}-\mathrm{CP}-\mathrm{C}(48 \%)>11 \mathrm{Co}-\mathrm{CP}-\mathrm{A}(28 \%)$ \\
\hline & TPDC & (surface) $\quad 11 \mathrm{Co}-\mathrm{IW}-\mathrm{C}>11 \mathrm{Co}-\mathrm{IW}-\mathrm{A}$ \\
\hline
\end{tabular}

a: The TPR measurements on Altamira system using $\mathrm{H}_{2}$-uptake detection by TCD.

b: The TPR measurements on the reaction system using $\mathrm{H}_{2} \mathrm{O}$ detection by MS.

c: Assuming the increase in $\mathrm{H}_{2}$-uptake was mainly due to further reduction of cobalt.

extents of interaction between cobalt and copper in the catalyst samples of this study have been indicated by the results of TPR measurements and supported by the results of physical measurements.

The shifts of the major TPR peaks with inclusion of increasing amount of cobalt in $\mathrm{CuO} / \mathrm{ZnO}$ shown by Figure 12 was consistent with the fact that the reduction of cobalt oxides is more difficult than copper oxides, and suggested that the interaction between cobalt and copper inhibited the reduction of copper. On the other hand, the TPR studies of supported cobalt catalysts $(47,103)$ 
showed that the major TPR peak for cobalt on $\mathrm{SiO}_{2}$ or $\mathrm{Al}_{2} \mathrm{O}_{3}$ appeared between $250 \sim 500^{\circ} \mathrm{C}$, but Figure 12 showed no peak in this range of temperature. This suggested that the reduction temperature of cobalt was lowered by the presence of copper, which also indicated the presence of cobaltcopper interaction. As indicated in both Table 10 and Table 13, the reduction extent of cobalt in 05Co-IW-A was significantly higher than in 11Co-IW-A, apparently related to the higher atomic ratio of $\mathrm{Cu}: \mathrm{Co}$ in $05 \mathrm{Co}-\mathrm{IW}$ than in 11 Co-IW. This is consistent with the interpretation that the interaction of copper with cobalt promoted the reduction of cobalt. The observations of cobalt -reduction aided by copper have also been reported in the literature $(6,40$, $48,97)$. The broadening of the TPR peak caused by reduction $B$ could be due to both the interaction of cobalt with copper and a diffusion effect of increased total pressure, which again indicates the $\mathrm{Co}-\mathrm{Cu}$ interaction.

The increasing trend in cobalt reduction extent of $11 \mathrm{Co}-\mathrm{CP}$ with the reduction treatments observed from TPR measurements, as shown in Table 13, was consistent with the result of XPS measurement. This indicates that using a reducing gas with a high $\mathrm{H}_{2}$ partial pressure could enhance the extent of reduction of cobalt significantly. Nevertheless, this trend in reduction extent was hardly observed with $11 \mathrm{Co}-\mathrm{IW}$ samples. A reasonable explanation for this is that the extent of interaction between cobalt and copper in 11Co-IW was significantly less than in 11 Co-CP, which could be related to the premixing state of the metal oxides resulted from catalyst preparation.

Since XRD and XPS results indicated that copper was always completely reduced with any reduction treatment, the fact observed from TPR experiments that compared with treatment $A$ in Figure 13 treatment $C$ of 
11 Co-CP caused no change in the intensity of the down-shifted low temperature peak but an increase in the intensity of the unshifted high temperature peak indicated a further reduction of cobalt with only small enhancement in the rate of copper reduction at low temperature. The fact that compared with treatment $\mathrm{A}$ in Figure 14 treatment $\mathrm{C}$ of $11 \mathrm{Co}-\mathrm{IW}$ caused a significant increase of the down-shifted low temperature peak without any increase in the high temperature range indicated little further cobalt reduction but significant enhancement in the rate of copper reduction at low temperature. This observation again suggested that the cobalt-copper interaction in $11 \mathrm{Co}-\mathrm{CP}$ was more abundant than in $11 \mathrm{Co}-\mathrm{IW}$, which promoted the further reduction of cobalt and inhibited the enhancement in copper reduction rate at low temperature.

4.2.2.3 Location of $\mathrm{Co}^{\circ}$ on the Catalyst Surface. Another issue addressed by the charaterization studies was the location of cobalt metal atoms or particles on the catalyst surface. This is important for understanding the role(s) of $\mathrm{Co}^{\circ}$ in constructing the active sites for the synthesis of $\mathrm{C}_{2+}$ alcohols.

The fact that the TPR result indicated similar reduction extent of cobalt in 11Co-CP-A and 11Co-IW-A while the XPS result indicated the reduction extent of cobalt on the surface of 11Co-CP-A was higher than on 11Co-IW-A, refer Table 13, suggested that the distribution of cobalt metal atoms in $11 \mathrm{Co}-$ CP-A was more concentrated on the surface than in 11Co-IW-A. What could be the reason that caused this distribution? As discussed in the previous section, interaction of copper with cobalt was found to assist the reduction of cobalt, which suggested that the extent of cobalt-copper interaction in $11 \mathrm{Co}-\mathrm{CP}$ 
was more abundant than in 11Co-IW. It implies that cobalt oxides adjacent to copper phase would be easier to be reduced, and more interfacial contact between cobalt oxide phase and copper oxide phase would result in more cobalt reduction. Therefore, the higher concentration of $\mathrm{Co}^{\circ}$ atoms on the surface of $11 \mathrm{Co}-\mathrm{CP}-\mathrm{A}$ than on 11Co-IW-A could result from either higher copper surface area or higher dispersion of cobalt phase in $11 \mathrm{Co}-\mathrm{CP}$ than in $11 \mathrm{Co}-\mathrm{IW}$, and the $\mathrm{Co}^{\circ}$ phase located near to the copper metal surface. In fact, the XRD spectra of $11 \mathrm{Co}-\mathrm{CP}-\mathrm{O}$ and $11 \mathrm{Co}-\mathrm{IW}-\mathrm{O}$ did not show significant difference in the particle size of $\mathrm{Co}_{3} \mathrm{O}_{4}$, but the XRD spectra of $11 \mathrm{Co}-\mathrm{CP}-\mathrm{A}$ and 11Co-IW-A indicated that the overall particle size of $\mathrm{Cu}^{\circ}$ in $11 \mathrm{Co}-\mathrm{CP}-\mathrm{A}$ was smaller than in 11Co-IW-A. In addition, the $\mathrm{H}_{2}$-TPD results (see Table 12) showed significantly higher hydrogen coverage per milligram of $\mathrm{Co}^{\circ}+\mathrm{Cu}^{\circ}$ on 11Co-CP-A than on 11Co-IW-A while the TPR results (see Table 10) showed similar extent of reduction of cobalt in these two samples, which also suggests higher $\mathrm{Cu}^{\circ}$ dispersion in $11 \mathrm{Co}-\mathrm{CP}-\mathrm{A}$ than in $11 \mathrm{Co}-\mathrm{IW}-\mathrm{A}$. This implies that it was the higher surface area of copper metal in $11 \mathrm{Co}-\mathrm{CP}-\mathrm{A}$ that played a key role in resulting the higher concentration of $\mathrm{Co}^{\circ}$ on the surface than in $11 \mathrm{Co}$ IW-A. In other words, it suggested that in $11 \mathrm{Co}-\mathrm{CP}-\mathrm{A}$, the $\mathrm{Co}^{\circ}$ atoms were mostly associated with the copper metal surface while in 11Co-IW-A, the $\mathrm{Co}^{\circ}$ phase had less contact with the copper metal surface. As it was indicated by the BET and XRD results that no significant sintering in particle size was caused by the addition of cobalt; the fact that addition of cobalt to $\mathrm{Cu} / \mathrm{ZnO}$ (comparing $11 \mathrm{Co}-\mathrm{IW}-\mathrm{A}$ with $00 \mathrm{Co}-\mathrm{IW}-\mathrm{A}$ in Table 12) caused little change in $\mathrm{H}_{2}$-uptake capability of the surface suggested that the surface cobalt metal atoms were mostly on top of copper metal atoms. The TPR and XPS results 
indicated that reduction extent of cobalt was higher in $11 \mathrm{Co}-\mathrm{CP}-\mathrm{C}$ than in 11Co-CP-A, XRD and XPS results indicated complete reduction of copper in both samples, and no significant sintering of $\mathrm{Cu}^{\circ}$ particle was shown by XRD spectra, but the TPD results showed almost the same amount of $\mathrm{H}_{2}$-uptake on $11 \mathrm{Co}-\mathrm{CP}-\mathrm{C}$ as on $11 \mathrm{Co}-\mathrm{CP}-\mathrm{A}$. This suggested that the further reduced cobalt in $11 \mathrm{Co}-\mathrm{CP}-\mathrm{C}$ was on top of surface copper metal which blocked some of the $\mathrm{H}_{2}$ uptake sites of copper metal and formed new $\mathrm{H}_{2}$-uptake sites. Compared with the TPD spectrum of $11 \mathrm{Co}-\mathrm{CP}-\mathrm{A}$, the slight increase in the low temperature peak of 11Co-IW-C accompanied with a slight decrease in the high temperature peak was consistent with interpretation that the further formed $\mathrm{Co}^{\circ}$ was mostly on top of $\mathrm{Co}^{\circ}$ in $11 \mathrm{Co}-\mathrm{CP}-\mathrm{C}$. The fact that $\mathrm{H}_{2}$-uptake on $11 \mathrm{Co}$ IW-C was significantly higher than on $11 \mathrm{Co}-\mathrm{IW}-\mathrm{A}$ and the extra $\mathrm{H}_{2}$-uptake was mainly desorbed at low temperatures suggested that reduction $\mathrm{C}$ of $11 \mathrm{Co}-$ IW resulted in more weak $\mathrm{H}_{2}$ adsorption sites but not necessarily more $\mathrm{Co}^{\circ}$ on top of $\mathrm{Cu}$ metal. Since the TPR result showed little further bulk reduction in $11 \mathrm{Co}-\mathrm{IW}-\mathrm{C}$ compared with $11 \mathrm{Co}-\mathrm{IW}-\mathrm{A}$, the increase in weak- $\mathrm{H}_{2}$-adsorption could be attributed mainly to increased dispersion of $\mathrm{Co}^{\circ}$ on the surface of oxides.

\subsection{Conclusions}

The characterization studies of the different $\mathrm{Co}-\mathrm{Cu}$ catalyst samples receiving different reduction treatments provided information that could help in understanding the roles of key catalyst components in constructing the active sites for the selective synthesis of $\mathrm{C}_{2}+$ alcohols from $\mathrm{CO} / \mathrm{H}_{2}$. A 
summary of the information revealed by the catalyst characterization studies is given below.

(1) Prior to reduction treatment, all four catalyst samples had similar BET surface area; copper was present in the state of $\mathrm{CuO}$ and cobalt in $\mathrm{CO}_{3} \mathrm{O}_{4}$; the dispersion of $\mathrm{CO}_{3} \mathrm{O}_{4}$ particles was in the order of $05 \mathrm{Co}-\mathrm{IW}-\mathrm{O}>11 \mathrm{Co}-\mathrm{CP}-\mathrm{O}$ $>11 \mathrm{Co}-\mathrm{IW}-\mathrm{O}$; the $\mathrm{Co}_{3} \mathrm{O}_{4}$ was better mixed with $\mathrm{CuO}$ in $11 \mathrm{Co}-\mathrm{CP}-\mathrm{O}$ than in 11Co-IW-O.

(2) Post reduction treatment A, copper was completely reduced in all four samples; cobalt was almost totally reduced in 05Co-IW-A and partially reduced in $11 \mathrm{Co}-\mathrm{IW}-\mathrm{A}$ and $11 \mathrm{Co}-\mathrm{CP}-\mathrm{A}$; the local atomic ratio of $\mathrm{Co}^{\circ} / \mathrm{Cu}^{\circ}$ on the surface of $11 \mathrm{Co}-\mathrm{CP}-\mathrm{A}$ was significantly higher than on $11 \mathrm{Co}-\mathrm{IW}-\mathrm{A}$; the amount of hydrogen adsorption sites on 11Co-IW-A was about the same as on $00 \mathrm{Co}-\mathrm{IW}-\mathrm{A}$ but lower than on $11 \mathrm{Co}-\mathrm{CP}-\mathrm{A}$; the $\mathrm{Co}^{\circ}$ in $11 \mathrm{Co}-\mathrm{IW}$ samples was suggested to be to a large extent on top of surface copper metal sites.

(3) Post reduction treatment B and C, copper was completely reduced in all cases and cobalt was partially reduced; the particle sizes of $\mathrm{Cu}^{\circ}$ were similar to those of the corresponding samples receiving treatment $\mathrm{A}$; the reduction extents of cobalt in the bulk of $11 \mathrm{Co}-\mathrm{CP}$ samples were in the order of $11 \mathrm{Co}-\mathrm{CP}$ C. $>11 \mathrm{Co}-\mathrm{CP}-\mathrm{B}>11 \mathrm{Co}-\mathrm{CP}-\mathrm{A}$, but the reduction extents of cobalt in the bulk of $11 \mathrm{Co}-\mathrm{IW}-\mathrm{B}$ and $11 \mathrm{Co}-\mathrm{IW}-\mathrm{C}$ were about the same as in 11Co-IW-A; the amount of $\mathrm{H}_{2}$-adsorption sites was higher on the surface of $11 \mathrm{Co}-\mathrm{CP}$ samples than on $11 \mathrm{Co}-\mathrm{IW}$ samples; the $\mathrm{Co}^{\circ}$ on $11 \mathrm{Co}-\mathrm{CP}$ samples was suggested to be mostly on top of surface copper metal, but on 11Co-IW samples was less associated with the surface of copper metal than on 11Co-CP samples.

(4) Post CO hydrogenation reaction, no significant loss in BET surface 
area with little sintering of $\mathrm{Cu}^{\circ}$ was observed; agglomeration or re-oxidation of $\mathrm{CO}_{3} \mathrm{O}_{4}$ in $11 \mathrm{Co}-\mathrm{CP}$ samples was indicated but not in $11 \mathrm{Co}-\mathrm{IW}$ samples. 


\subsection{CO HYDROGENATION}

\subsection{Results}

The activities and selectivities of $\mathrm{CO}$. hydrogenation reactions at steady state over the catalysts pretreated by different reduction treatments are summarized in Table 14 and 15. The formation of higher alcohols over these Co-Cu catalysts did not follow ASF kinetics although hydrocarbon formation did (see Figure E1 E6 in Appendix E).

\subsubsection{Reduction Treatment A}

Comparison between the data obtained over non-cobalt and cobaltcontaining samples (for all treatments) showed that the inclusion of cobalt in $\mathrm{Cu} / \mathrm{ZnO}$ reduced methanol and dimethylether formation drastically (by almost an order of magnitude) and the changes in selectivity with the cobalt addition were mainly due to this selective suppression of methanol.

The increase in Co loading from $5 \%$ to $11 \%$ resulted in slight further suppression of methanol and dimethyl ether formation with small increases in $\mathrm{C}_{2}$ alcohols and methane but little effect on $\mathrm{C}_{2}$ - hydrocarbons. With treatment $\mathrm{A}$, the two samples with same amount of cobalt loading but different atomic ratio of $\mathrm{Co}: \mathrm{Cu}$ and prepared by different methods, 11Co-CP-A and 11Co-IW-A, demonstrated similar activities for the formation of $\mathrm{C}_{2}+$ alcohols. The higher selectivity for $\mathrm{C}_{2}+$ alcohols formation over $11 \mathrm{Co}-\mathrm{CP}-\mathrm{A}$ than 11Co-IW-A was mainly due to the lower formation rate of methanol 
Table 14 Activities of CO Hydrogenation Reactions at Steady State

\begin{tabular}{|c|c|c|c|c|c|c|c|c|c|c|c|c|}
\hline \multirow{2}{*}{$\begin{array}{l}\text { Catalyst: } \\
\text { Reduction Condition }{ }^{b} \text { : }\end{array}$} & \multicolumn{6}{|c|}{$11 \mathrm{Co} C \mathrm{P}$} & \multicolumn{3}{|c|}{ 11Co-IW } & \multirow{2}{*}{$\frac{05 \mathrm{Co}-\mathrm{IW}}{\mathrm{A}}$} & \multicolumn{2}{|c|}{$00 \mathrm{Co}-\mathrm{IW}$} \\
\hline & $\mathbf{A}$ & B & C & $\mathbf{D}$ & $\mathbf{E}$ & $\mathbf{F}$ & $\mathbf{A}$ & B & C & & $\mathbf{A}$ & B \\
\hline & \multicolumn{12}{|c|}{ ACTIVITY, ( g/kg-cat $/ \mathrm{hr}$ ) } \\
\hline OXYGENATES: & 17.3 & $\mathbf{5 4 . 4}$ & 68.7 & 69.5 & 34.6 & 51.1 & 52.6 & 72.3 & 65.8 & 53.7 & 499.3 & 565.2 \\
\hline Methanol & 7.5 & 13.9 & 18.2 & 18.0 & 12.6 & 16.1 & 42.8 & 55.5 & 53.7 & 45.9 & 411.4 & 545.3 \\
\hline Dimethylether & 0 & 0 & 0 & 0 & 0 & 0 & 0.5 & 0.2 & 0.3 & 2.2 & 15.9 & 15.8 \\
\hline Ethanol & 6.6 & 13.9 & 16.7 & 17.6 & 9.5 & 14.4 & 6.1 & 8.2 & 6.3 & 4.1 & 11.4 & 3.1 \\
\hline n-Propanol & 2.0 & 6.6 & 8.2 & 8.2 & 5.4 & 7.5 & 2.8 & 5.7 & 4.1 & 1.5 & 0.6 & 1.0 \\
\hline n-Butanol & 1.2 & 7.0 & 8.1 & 8.1 & 3.8 & 6.2 & 0.4 & 1.8 & 1.0 & 0 & 0 & 0 \\
\hline n-Penthanol & 0 & 6.1 & 7.4 & 9.9 & 2.0 & 4.2 & 0 & 0.9 & 0.4 & 0 & 0 & 0 \\
\hline n-Hexanol & $\mathbf{0}$ & 6.9 & 10.1 & 7.7 & 1.3 & 2.7 & 0 & 0 & 0 & 0 & 0 & 0 \\
\hline HYDROCARBONS: & 13.9 & 30.4 & 32.6 & 35.5 & 17.2 & 24.6 & 15.0 & 15.5 & 17.5 & 11.4 & 14.0 & 12.2 \\
\hline Methane & 5.4 & 12.5 & 13.5 & 14.1 & 7.2 & 10.0 & 9.2 & 9.2 & 10.7 & 5.1 & 5.9 & 4.9 \\
\hline $\mathrm{C}_{2} \mathrm{HCS}$ & 2.8 & 5.7 & 6.3 & 6.8 & 3.3 & 4.8 & 3.6 & 3.6 & 4.3 & 3.3 & 1.1 & 2.2 \\
\hline $\mathrm{C}_{3^{+}} \mathrm{HCs}$ & 5.7 & 12.2 & 12.8 & 14.6 & 6.7 & 9.8 & 2.2 & 2.7 & 2.5 & 3.0 & 7.0 & 5.1 \\
\hline OXYs + HCs : & 31.2 & 84.2 & 101.3 & 105.0 & $\mathbf{5 1 . 8}$ & $\mathbf{7 5 . 7}$ & 67.6 & $\mathbf{8 7 . 8}$ & 83.3 & 65.1 & 453.3 & 577.4 \\
\hline $\mathrm{CO}_{2}$ : & 91.7 & 157.9 & 168.2 & 185.5 & 99.4 & 150.7 & 53.8 & 51.2 & 48.8 & 43.1 & 43.5 & 25.5 \\
\hline \multirow[t]{3}{*}{$\begin{array}{l}\text { CATȦLYST WEIGHT, } \\
\text { (mg/bed) : }\end{array}$} & 463.5 & 249.5 & 249.3 & 250.5 & 251.5 & 252.3 & 470.2 & 505.4 & 500.8 & 536.1 & 75.0 & 59.8 \\
\hline & \multicolumn{12}{|c|}{ CO CONVERSION, ( $\mathrm{mol} \%)$} \\
\hline & 1.6 & 1.9 & 2.1 & 2.2 & 1.2 & 1.7 & 1.7 & 2.2 & 2.1 & 1.6 & 1.1 & 1.0 \\
\hline
\end{tabular}

a: Refer section 3.3.3 for reaction conditions. b: Refer section 3.1.2 for reduction conditions. 
Table 15 Selectivities of CO Hydrogenation Reactions at Steady State ${ }^{a}$

\begin{tabular}{|c|c|c|c|c|c|c|c|c|c|c|c|c|}
\hline \multirow{2}{*}{$\begin{array}{l}\text { Catalyst: } \\
\text { Reduction Condition }{ }^{b} \text { : }\end{array}$} & \multicolumn{6}{|c|}{$11 \mathrm{CO}_{\mathrm{CP}}$} & \multicolumn{3}{|c|}{$11 \mathrm{C}-\mathrm{IW}$} & \multirow{2}{*}{$\frac{05 \mathrm{C}_{0}-\mathrm{IW}}{\mathrm{A}}$} & \multicolumn{2}{|c|}{ 00Co-IW } \\
\hline & $\mathbf{A}$ & B & C & $\mathbf{D}$ & $\mathbf{E}$ & $\mathbf{F}$ & $\mathbf{A}$ & B & C & & $\mathbf{A}$ & B \\
\hline & \multicolumn{12}{|c|}{ SELECTIVITYc, ( wt\%) } \\
\hline $\mathrm{C}_{2^{+}}$Alc. $/ \mathrm{C}_{1} \sim \mathrm{C}_{6}$ Alc.: & 56.7 & 74.5 & 73.6 & $\mathbf{7 4 . 0}$ & 63.5 & 68.6 & 18.6 & 22.9 & 18.2 & 14.4 & 6.3 & 3.5 \\
\hline OXYGENATES: & 55.4 & 64.2 & 67.8 & 66.2 & 66.8 & 67.5 & 77.8 & 82.3 & 79.0 & 82.4 & 96.9 & 97.9 \\
\hline Methanol & 24.0 & 16.4 & 17.9 & 17.2 & 24.4 & 21.2 & 63.3 & 63.3 & 64.4 & 70.5 & 90.8 & 94.4 \\
\hline Dimethylether & 0 & 0 & 0 & 0 & 0 & 0 & 0.7 & 0.2 & 0.3 & 3.4 & 3.5 & 2.7 \\
\hline Ethanol & 21.2 & 16.4 & 16.5 & 16.7 & 18.3 & 19.0 & 9.0 & 9.3 & 7.6 & 6.2 & 2.5 & 0.5 \\
\hline n-Propanol & 6.4 & 7.8 & 8.1 & 7.9 & 10.4 & 10.0 & 4.2 & 6.5 & 4.9 & 2.3 & 0.1 & 0.2 \\
\hline n-Butanol & 3.8 & 8.3 & 8.0 & 7.7 & 7.3 & 8.2 & 0.6 & 2.1 & 1.3 & 0 & 0 & 0 \\
\hline n-Penthanol & 0 & 7.2 & 7.3 & 9.4 & 3.9 & 5.6 & 0 & 1.0 & 0.5 & 0 & $\mathbf{0}$ & 0 \\
\hline n-Hexanol & 0 & 8.1 & 10.0 & 7.3 & 2.5 & 3.6 & 0 & 0 & 0 & 0 & 0 & 0 \\
\hline HYDROCARBONS: & 44.6 & 35.8 & 32.2 & 33.8 & 33.2 & 32.5 & 22.2 & 17.7 & 21.0 & 17.6 & 3.1 & 2.1 \\
\hline Methane & 17.3 & 14.7 & 13.3 & 13.4 & 14.0 & 13.2 & 13.7 & 10.5 & 12.9 & 7.8 & 1.3 & 0.8 \\
\hline $\mathrm{C} 2 \mathrm{HCS}$ & 9.0 & 6.7 & 6.3 & 6.5 & 6.5 & 6.4 & 5.3 & 4.1 & 5.1 & 5.1 & 0.2 & 0.4 \\
\hline $\mathrm{C}_{3}+\mathrm{HCs}$ & 18.3 & 14.4 & 12.6 & 13.9 & 12.7 & 12.9 & 3.2 & 3.1 & 3.0 & 4.7 & 1.6 & 0.9 \\
\hline
\end{tabular}

a: Refer section $\mathbf{3 . 3 . 3}$ for reaction conditions.

b: Refer section 3.1 .2 for reduction conditions.

c: $\mathrm{CO}_{2}$ is not included. 
over 11Co-CP-A than 11Co-IW-A.

\subsubsection{Reduction Treatment B and C}

Comparison between the data for $11 \mathrm{Co}-\mathrm{CP}$ samples receiving different reduction treatments showed dramatic differences in the activities for the formation of all alcohols and hydrocarbons as well as the selectivities for $\mathrm{C}_{2}+$ alcohol formation. The activities increased in the order of $A \ll B<C$, and the selectivities for $\mathrm{C}_{2^{+}}$alcohol formation increased in the order of $\mathrm{A}<\mathrm{B} \approx \mathrm{C}$. Treatments $B$ and $C$ for $11 \mathrm{Co}-\mathrm{CP}$ resulted in a more than 3-fold increase in the activities of oxygenates formation and $C_{5}$ and $C_{6}$ alcohols were observed under these conditions. Compared with treatment $A$, treatments $D, E$ and $F$ for $11 \mathrm{Co}-\mathrm{CP}$ also resulted in similar increases in the activity and selectivity of oxygenates with significant detection of $C_{5}$ and $C_{6}$ alcohols, although the selectivity of $\mathrm{E}$ is closer to $\mathrm{A}$.

Over 11Co-IW, the activities for the formation of all alcohols and the selectivities for $\mathrm{C}_{2}+$ alcohols also increased with different reduction treatments in the order of $\mathrm{A}<\mathrm{C}<\mathrm{B}$ while hydrocarbons were hardly affected. However, the promotion effect of reduction treatment $B$ and $C$ on the synthesis of $\mathrm{C}_{2}$ alcohols was much less significant with 11Co-IW.

Over 00Co-IW, reduction $A$ and $B$ resulted in almost the same activities and selectivities of the $\mathrm{CO}$ hydrogenation reaction products except for a relatively small increase in methanol formation with reduction $B$. 


\subsubsection{Effect of $\mathrm{CO}_{2}$ Addition}

Figure 20 presents the effect of $\mathrm{CO}_{2}$ addition to the $\mathrm{CO} / \mathrm{H}_{2}$ reaction on the formation rates of $\mathrm{CO}$ hydrogenation products over (a) $00 \mathrm{Co}-\mathrm{IW}$ and (b) $11 \mathrm{Co}-$ $\mathrm{IW}$, both receiving reduction treatment $\mathrm{A}$. The addition of $\mathrm{CO}_{2}$ promoted the rate of methanol formation by 3 times over 00Co-IW but only 0.3 times over 11Co-IW. This showed that another significant effect of the cobalt addition to $\mathrm{Cu} / \mathrm{ZnO}$ was to suppress the promotion effect of $\mathrm{CO}_{2}$ on methanol formation.

\subsection{Discussion}

\subsubsection{Effect of Presence of $\mathrm{Co}$ in $\mathrm{Cu} / \mathrm{ZnO}$}

The observation that cobalt addition to $\mathrm{Cu} / \mathrm{ZnO} / \mathrm{Al}_{2} \mathrm{O}_{3}$ caused a drastic suppression of methanol formation and therefore significantly dropped the overall activities of the catalysts is consistent with the activity data of the Co$\mathrm{Cu}$ type of catalysts reported in the patent literature ${ }^{(42-44)}$ for the synthesis of $\mathrm{C}_{2}+$ alcohols from $\mathrm{CO}$ and $\mathrm{H}_{2}$. The insignificant changes in both BET surface area and the XRD spectrum of $\mathrm{Cu} / \mathrm{ZnO} / \mathrm{Al}_{2} \mathrm{O}_{3}$ with the addition of $\mathrm{Co}$ implied that the dramatic changes in activity and selectivity were mainly caused by surface modification. As studies in the literature $(52,79,83)$ suggest that the formation of methanol from $\mathrm{CO}_{2} / \mathrm{H}_{2}$ requires $\mathrm{Cu}^{\circ}$ sites, the suppression of $\mathrm{CO}_{2}$ promotion effect on methanol formation by cobalt addition suggested a blockage or deactivation of copper metal sites by cobalt addition. The fact that both XRD and XPS results showed complete reduction 

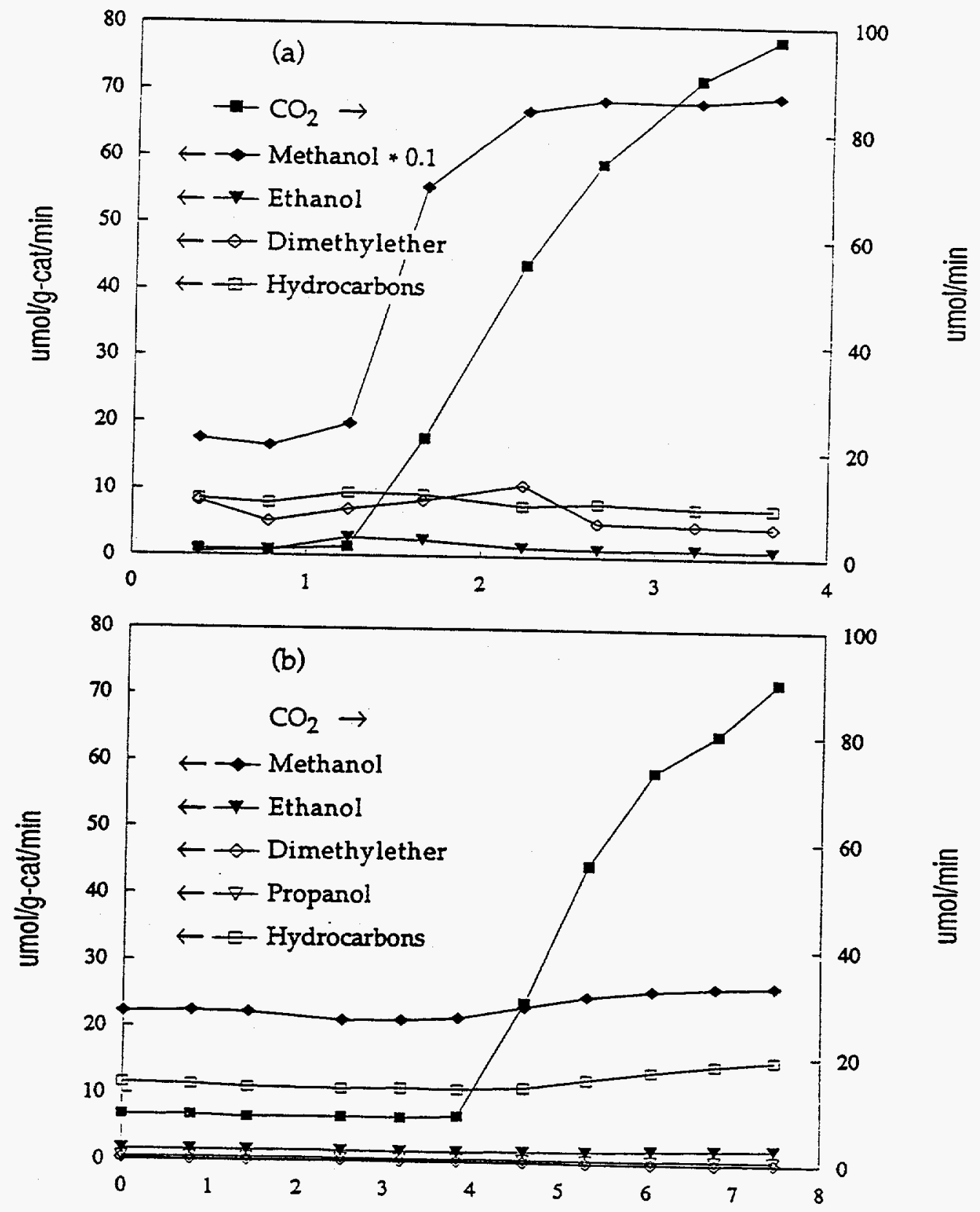

Time, ( hr )

Figure 20 Effect of $\mathrm{CO}_{2}$ Addition to $\mathrm{CO} / \mathrm{H}_{2}$ Stream on the Formation Rates of $\mathrm{CO}$ Hydrogenation Products over (a) 00Co-IW and (b) 11Co-IW at $500 \mathrm{psig}, 290^{\circ} \mathrm{C}, \mathrm{CO} / \mathrm{H}_{2} / \mathrm{He} / \mathrm{CO}_{2}=40 / 80 / 2-\mathrm{x} / \mathrm{x}, \mathrm{x}=0 \sim 2, \mathrm{cc} / \mathrm{min}$ 
of copper after any of the reduction treatment with either non-cobalt or cobalt-containing catalyst also suggested that the suppression of methanol by the addition of cobalt could mainly be due to a blockage or deactivation of the active $\mathrm{Cu}^{\circ}$ sites by cobalt. This is consistent with the TPD results in section 4.0 which suggested that the cobalt addition caused a partial coverage of surface $\mathrm{Cu}^{\circ}$ by $\mathrm{Co}^{\circ}$. Lin and Pennella ${ }^{(97)}$ observed a similar phenomenon where even very small amounts of Co resulted in significant suppression of methanol formation and caused little change in the bulk properties of the catalyst. In that study, it was suggested that the suppression of methanol was attributed to the selective interaction of the cobalt with the active sites of methanol synthesis on the $\mathrm{Cu} / \mathrm{ZnO}$ surface. Therefore, the drastic and selective suppression of methanol as well as dimethylether formation upon inclusion of cobalt in $\mathrm{Cu} / \mathrm{ZnO}$ is suggested to be attributed to the coverage of surface copper metal sites by cobalt.

The relatively insignificant difference in the formation rates of methanol and dimethyl ether observed between the data of 11Co-IW-A with $05 \mathrm{Co}$-IW-A suggests that the increase in cobalt loading from $5 \%$ to $11 \%$ did not significantly increase the coverage of copper metal sites with cobalt. This is consistent with the XRD results indicating that the dispersion of cobaltcontaining phase in 05Co-IW sample was significantly higher than in $11 \mathrm{Co}-$ IW sample. Comparing with the data of $11 \mathrm{Co}-\mathrm{IW}-\mathrm{A}$ and $05 \mathrm{Co}-\mathrm{IW}-\mathrm{A}$, the significantly lower rates of methanol and dimethyl ether formation over $11 \mathrm{Co}-\mathrm{CP}-\mathrm{A}$ was apparently related to the lower amount of copper in $11 \mathrm{Co}-\mathrm{CP}$ sample. However, it could also be due to a much higher coverage of copper metal surface with cobalt on 11Co-CP-A, which was consistent with the fact 
indicated by XPS result that the atomic ratio of $\mathrm{Co}^{\circ} / \mathrm{Cu}^{\circ}$ was higher on the surface of 11 Co-CP-A than on 11Co-IW-A.

The observation from the characterization results that copper assisted the reduction of cobalt in close contact with copper and that the cobalt metal particles were very finely dispersed in the catalyst samples suggested that the cobalt covering copper surface was very finely dispersed. Therefore, the insignificant changes in the formation rates of $\mathrm{C}_{2}+$ alcohols and hydrocarbons with the inclusion of cobalt observed from comparing the data of 05-Co-IWA, 11Co-IW-A and 11Co-CP-A with 00Co-IW-A implied that the very finely dispersed $\mathrm{Co}^{\circ}$ on the copper metal surface, which drastically suppressed methanol formation, had little activity for the synthesis of either $\mathrm{C}_{2}+$ alcohols or hydrocarbons. It could be due to that the surface area of $\mathrm{Co}^{\circ}$ was too low for carbon chain growth, or, when $\mathrm{Co}^{\circ}$ particle was too small the electronic influence of copper metal might significantly change the $\mathrm{CO}$ hydrogenation property of cobalt metal.

\subsubsection{Effect of Reduction Treatment}

The significant increase in $\mathrm{C}_{2}$ alcohols that came about as a result of treatment at higher hydrogen partial pressures suggests a crucial change related to the nature of the active sites for alcohol synthesis. The fact that 00Co-IW samples receiving reduction treatment $A$ and $B$ gave almost the same activity and selectivity provided strong evidence indicating that cobalt metal played a key role in constructing these active sites over $\mathrm{Co}-\mathrm{Cu}$ based catalysts for the synthesis of $\mathrm{C}_{2}$ alcohols. 
Consistent with the characterization results that the further reduced cobalt metal in 11Co-CP-C was mostly in close contact with surface copper metal, the significant enhancement of activity and selectivity of higher alcohol synthesis over $11 \mathrm{Co}-\mathrm{CP}-\mathrm{C}$ was apparently related to the significant improvement in local atomic ratio of $\mathrm{Co}^{\circ} / \mathrm{Cu}^{\circ}$ caused by reductions using high $\mathrm{H}_{2}$ partial pressure. As cobalt alone has been well known as an active metal for hydrocarbon synthesis from $\mathrm{CO} / \mathrm{H}_{2}$, it is not surprising to observe an increase in hydrocarbon formation with increased cobalt reduction extent. Since the TPR results indicated that treatment $B, D, E$ and $F$ of 11 Co-CP all resulted in further reduction of cobalt comparing with treatment $A$, the fact that these treatments also resulted in significant increase in the formation rates of $C_{2} \sim C_{6}$ alcohols provided further evidence that improving the condition of $\mathrm{Co}^{\circ}-\mathrm{Cu}^{\circ}$ contact prior to $\mathrm{CO}$ hydrogenation reaction could create more active sites for higher alcohol synthesis. In fact, this explanation has strong support from the studies in the literature $(6,40,45-50,97,98)$ which all suggested that the local contact between $\mathrm{Co}$ and $\mathrm{Cu}$ in the catalyst is an essential factor for selective production of $C_{2} \sim C_{6}$ alcohols.

However, as discussed above, it was also suggested that the very finely dispersed $\mathrm{Co}^{\circ}$ on $\mathrm{Cu}^{\circ}$ had little activity for $\mathrm{C}_{2}$ alcohol synthesis. It indicated that only a specific type of contact between cobalt and copper could form the active sites for $C_{2} \sim C_{6}$ alcohol synthesis. The fact that increased local atomic ratio of $\mathrm{Co}^{\circ} / \mathrm{Cu}^{\circ}$ was shown to be related to the active sites for $\mathrm{C}_{2} \sim \mathrm{C}_{6}$ alcohol synthesis could be an indication that a reasonable particle size of $\mathrm{Co}^{\circ}$ on $\mathrm{Cu}^{\circ}$ was required for the $\mathrm{Co}^{\circ}$ to have significant activity, such as $\mathrm{CO}$ dissociation or chain growth probability, for the formation of $\mathrm{C}_{2}$ alcohols. 
Over 00Co-IW-C, the slight increase in methanol formation rate was consistent with the TPD result indicating a slight increase in the dispersion of copper metal which could not be detected by XRD. This observation also provided a suggestion that the increase in methanol formation with treatment $B$ or $C$ observed over $11 \mathrm{Co}-\mathrm{IW}$ and $11 \mathrm{Co}-\mathrm{CP}$ samples was caused by the same reason even though the TPD results of cobalt-containing samples could not differentiate the surface $\mathrm{Co}^{\circ}$ from surface $\mathrm{Cu}^{\circ}$. The fact that TPR measurements did not show increase in overall reduction extent of cobalt in 11Co-IW-B and 11Co-IW-C but the activities and selectivities of $\mathrm{C}_{2}+$ alcohol synthesis over $11 \mathrm{Co}-\mathrm{IW}-\mathrm{B}$ and $\mathrm{C}$ were slightly improved could be caused by a slight change in the distribution of $\mathrm{Co}^{\circ}$ in these samples related to the slight increase in surface area of copper metal, i.e. a slight increase in the amount of $\mathrm{Co}^{\circ}$ on $\mathrm{Cu}^{\circ}$ on the surface without changing the overall reduction extent of cobalt. This interpretation is supported by the TPD results showing large increase in low temperature peak of $11 \mathrm{Co}-\mathrm{IW}-\mathrm{C}$ compared with $11 \mathrm{Co}-\mathrm{IW}-\mathrm{A}$.

\subsubsection{Effect of Catalyst Preparation Method}

Another point revealed by the experimental results is that the cobalt added to the $\mathrm{CuO} / \mathrm{ZnO} / \mathrm{Al}_{2} \mathrm{O}_{3}$ by impregnation resulted in the $\mathrm{Co}^{\circ}$ sites that could adsorb $\mathrm{H}_{2}$ but did not have significant activity for the reaction. The TPD results indicated that the amount of weakly adsorbed $\mathrm{H}_{2}$ was much higher on $11 \mathrm{Co}-\mathrm{IW}-\mathrm{C}$ than on $11 \mathrm{Co}-\mathrm{IW}-\mathrm{A}$ but about the same on $11 \mathrm{Co}-\mathrm{CP}-\mathrm{C}$ as on $11 \mathrm{Co}-$ $\mathrm{CP}-\mathrm{A}$. However, the formation rates of oxygenates increased much less significantly on $11 \mathrm{Co}-\mathrm{IW}-\mathrm{C}$ than on $11 \mathrm{Co}-\mathrm{CP}-\mathrm{C}$ and hydrocarbon formation 
was hardly changed on 11Co-IW-C. This suggested that most of those "weak$\mathrm{H}_{2}$-adsorption-sites" observed with treatment $\mathrm{C}$ of $11 \mathrm{Co}$-IW were not active sites for the CO hydrogenation reaction.

As discussed in the section above, only a specific type of contact between cobalt and copper could form the active sites for $\mathrm{C}_{2} \sim \mathrm{C}_{6}$ alcohol synthesis, and appropriate local atomic ratio of $\mathrm{Co}^{\circ} / \mathrm{Cu}^{\circ}$ was related to the active sites for $\mathrm{C}_{2} \sim \mathrm{C}_{6}$ alcohol synthesis. Therefore, the less significant improvement in the activities of $\mathrm{C}_{2}$ alcohol formation over 11Co-IW-B and 11Co-IW-C compared to the $11 \mathrm{Co}-\mathrm{CP}$ samples indicated that the cobalt added to $\mathrm{CuO} / \mathrm{ZnO} / \mathrm{Al}_{2} \mathrm{O}_{3}$ by impregnation method did not result in the proper local contact between $\mathrm{Co}^{\circ}$ and $\mathrm{Cu}^{\circ}$ that has been suggested to be essential in constructing the active sites for higher alcohol synthesis.

\subsection{Conclusions}

The $\mathrm{CO}$ hydrogenation reaction results indicated that the inclusion of cobalt in $\mathrm{Cu} / \mathrm{ZnO}$ selectively and significantly suppressed the rate of methanol and dimethyl ether formation, as well as the promotion effect of $\mathrm{CO}_{2}$ on methanol formation, without significantly enhancing the formation rates of hydrocarbon products (treatment A). Consistent with the characterization results, these effects are attributed to the coverage of the surface copper metal by cobalt which was partially reduced and finely dispersed.

Supported by both the characterization results and studies reported in the literature, the effect of reduction treatments on the activity and selectivity of $\mathrm{CO}$ hydrogenation reaction over $\mathrm{Co}-\mathrm{Cu}$ based catalysts in comparison with 
over the non-cobalt $\mathrm{Cu}$ based catalysts revealed that local atomic ratio of $\mathrm{Co}^{\circ} / \mathrm{Cu}^{\circ}$ or proper contact between $\mathrm{Co}^{\circ}$ and $\mathrm{Cu}^{\circ}$ on the surface of $\mathrm{Co}-\mathrm{Cu}$ based catalyst was a key factor in constructing the active sites for higher alcohol synthesis, and improving the reduction extent of cobalt in contact with $\mathrm{Cu}$ could generate more active sites for higher alcohol synthesis if the proper Co$\mathrm{Cu}$ contact could be established. However, the comparison between the activity and selectivity results obtained over the $\mathrm{Co}-\mathrm{Cu}$ catalysts prepared by coprecipitation and impregnation methods showed that adding cobalt by impregnation method did not result in sufficient $\mathrm{Co}-\mathrm{Cu}$ contact or local atomic ratio of $\mathrm{Co}^{\circ} / \mathrm{Cu}^{\circ}$ necessary for construction of the active sites for higher alcohol formation. 


\subsection{ADDITION OF NITROMETHANE AS A PROBE MOLECULE}

\subsection{Results}

The effects of $\mathrm{CH}_{3} \mathrm{NO}_{2}$ addition to $\mathrm{H}_{2} / \mathrm{CO}$ on the steady state rates of $\mathrm{CO}$ hydrogenation products over 00Co-IW-A, 05Co-IW-A, 11Co-IW-A\&B and 11 Co-CP-A\&B are presented in Table 16 and Figures F1 F6 (in Appendix F). Products other than $\mathrm{CO}$ hydrogenation products detected during the addition of $\mathrm{CH}_{3} \mathrm{NO}_{2}$ were methlyamines and $\mathrm{NH}_{3}$ with $\left(\mathrm{CH}_{3}\right)_{3} \mathrm{~N}$ as the major product. No $\mathrm{CH}_{3} \mathrm{NO}_{2}$ was detected in the outlet stream. Since the level of $\left(\mathrm{CH}_{3}\right)_{2} \mathrm{NH}$, $\mathrm{CH}_{3} \mathrm{NH}_{2}$ and $\mathrm{NH}_{3}$ in the products stream was very low and MS detection of products is not very accurate for quantification, the rates for $\left(\mathrm{CH}_{3}\right)_{2} \mathrm{NH}$, $\mathrm{CH}_{3} \mathrm{NH}_{2}$ and $\mathrm{NH}_{3}$ should be considered as qualitative values. (Figures $\mathrm{F} 7 \sim \mathrm{F} 12$ in Appendix $\mathrm{F}$ show the detection of $\left(\mathrm{CH}_{3}\right)_{2} \mathrm{NH}, \mathrm{CH}_{3} \mathrm{NH}_{2}$ and $\mathrm{NH}_{3}$ by MS.)

$\mathrm{CH}_{3} \mathrm{NO}_{2}$ addition to $\mathrm{CO} / \mathrm{H}_{2}$ over the non-Co catalyst caused large increase in $\mathrm{CO}_{2}$ and doubled methanol formation rate, while over the $\mathrm{Co}-\mathrm{Cu}$ based catalysts caused suppression of methanol formation with much less or no increase in $\mathrm{CO}_{2}$ formation. Over both the non-Co and $\mathrm{Co}-\mathrm{Cu}$ catalysts, it resulted in the formation of methylamines and ammonia, i.e. $\left(\mathrm{CH}_{3}\right)_{3-n} \mathrm{NH}_{n}, \mathrm{n}$ $=0,1,2,3$. The effects of $\mathrm{CH}_{3} \mathrm{NO}_{2}$ addition over the $\mathrm{Co}-\mathrm{Cu}$ based catalysts on the formation rates of $\mathrm{C}_{2}$ alcohols, hydrocarbons and $\mathrm{CO}_{2}$ were dependent on the specific catalyst and reduction treatment. After the addition of $\mathrm{CH}_{3} \mathrm{NO}_{2}$ was stopped, the formation rates of $\left(\mathrm{CH}_{3}\right)_{3-\Omega} \mathrm{NH}_{n}$ products dropped to zero while the rates of $\mathrm{CO}$ hydrogenation products resembled the original steady states. Nitrogen balance during $\mathrm{CH}_{3} \mathrm{NO}_{2}$ addition was obtained with 00Co-IW, 
Table 16 Effects of $\mathrm{CH}_{3} \mathrm{NO}_{2}$ Addition to $\mathrm{H}_{2} / \mathrm{CO}$ on the $\mathrm{CO}$ Hydrogenationa over 00Co-IW-A, 05Co-IW-A, 11Co-IW-A\&B and 11Co-CP-A\&B (to be continued)

Catalysts:

g-cat/bed:

Figure \#c:

Steady States ${ }^{d}$ :

$\mathrm{CH}_{3} \mathrm{NO}_{2}$ :

PRODUCTS:

Methanol

Dimethyl ether

Ethanol

n-Propanol

n-Butanol

n-Pentanol

n-Hexanol

Methane

$\mathrm{C}_{2} \mathrm{HCs}$

$\mathrm{C}_{3}+\mathrm{HCs}$

$\mathrm{CO}_{2}$

$\left(\mathrm{CH}_{3}\right)_{3} \mathrm{~N}$

$\left(\mathrm{CH}_{3}\right)_{2} \mathrm{NH}$

$\mathrm{CH}_{3} \mathrm{NH}_{2}$

$\mathrm{NH}_{3}$

N Conversion, \% :

\section{Co-IW-A \\ 0.075}

F1

$\frac{\mathrm{I} I I I \frac{I^{\prime}}{(\mu \mathrm{mol} / \mathrm{g} \text {-cat } / \mathrm{min})}}{I / I}$

$\begin{array}{ll}0 & \mathbf{2 0 . 0}\end{array}$

0

214

$\begin{array}{rrrr}214.3 & 457.9 & 232.4 & 2.1 \\ 5.8 & 5.2 & 5.9 & 0.9 \\ 4.2 & 5.4 & 5.7 & 1.3 \\ 0.2 & 0.1 & 0.2 & 0.5 \\ 0 & 0 & 0 & - \\ 0 & 0 & 0 & - \\ 0 & 0 & 0 & -\end{array}$

$\begin{array}{lll}6.4 & 5.6 & 5.9\end{array}$

0.9

$\begin{array}{lll}0.6 & 0.7 & 0.9\end{array}$

1.2

$\begin{array}{lll}3.3 & 4.0 & 2.7\end{array}$

1.2

$\begin{array}{lll}16.5 & 127.9 & 23.3\end{array}$

7.8

$0 \cdot 16.60$

$-$

$1.0 \quad 0$

$2.6 \quad 0$

0.40

- 103

\section{Co-IW-A \\ 0.536}

F2

\section{$\frac{\mathrm{I} I \mathrm{II} \quad \mathrm{I}^{\prime}}{(\mu \mathrm{mol} / \mathrm{g}-\mathrm{cat} / \mathrm{min})} \quad \mathrm{I} / \mathrm{I}$}

$\begin{array}{llll}0 & 3.1 & 0 & -\end{array}$

$\begin{array}{rrrrr}. .1 & 23.9 & 14.7 & 25.4 & 0.6 \\ 0.9 & 0.8 & 0.1 & 0.9 & 0.1 \\ 1.3 & 1.5 & 0.9 & 1.4 & 0.6 \\ 0.5 & 0.4 & 0.2 & 0.4 & 0.5 \\ - & 0 & 0 & 0 & - \\ - & 0 & 0 & 0 & - \\ - & 0 & 0 & 0 & -\end{array}$

\footnotetext{
a: $500 \mathrm{psig}, 290^{\circ} \mathrm{C}, \mathrm{H}_{2}: \mathrm{CO}=2$, GHSV $=6,000 \sim 60,000 \mathrm{hr}^{-1}$.

b: Refer section 3.1.1 and 3.1.2 for the descriptions of catalysts and reduction treatments.

c: Figures presented in Appendix $\mathrm{F}$.

d: I : prior to $\mathrm{CH}_{3} \mathrm{NO}_{2}$ addition, I': post to $\mathrm{CH}_{3} \mathrm{NO}_{2}$ addition, II: during $\mathrm{CH}_{3} \mathrm{NO}_{2}$ addition, e: $\mathrm{N}$ conversion from $\mathrm{CH}_{3} \mathrm{NO}_{2}$ to methylamines and $\mathrm{NH}_{3}$. "-": N/A.
} 
Table 16 Effects of $\mathrm{CH}_{3} \mathrm{NO}_{2}$ Addition to $\mathrm{H}_{2} / \mathrm{CO}$ on the $\mathrm{CO}$ Hydrogenation a over 00Co-IW-A, 05Co-IW-A, 11Co-IW-A\&B and 11Co-CP-A\&Bb (continued)

Catalysts:

g-cat/bed:

Figure \#c:

Steady States ${ }^{\mathrm{d}}$ :

$\mathrm{CH}_{3} \mathrm{NO}_{2}$ :

PRODUCTS:

Methanol

Dimethyl ether

Ethanol

n-Propanol

n-Butanol

n-Pentanol

n-Hexanol

Methane

$\mathrm{C}_{2} \mathrm{HCs}$

$\mathrm{C}_{3}+\mathrm{HCs}$

$\mathrm{CO}_{2}$

$\left(\mathrm{CH}_{3}\right)_{3} \mathrm{~N}$

$\left(\mathrm{CH}_{3}\right)_{2} \mathrm{NH}$

$\mathrm{CH}_{3} \mathrm{NH}_{2}$

$\mathrm{NH}_{3}$

N Conversion, \%:
11Co-IW-A

0.470

F3 $\frac{\mathrm{I}}{(\mu \mathrm{mol} / \mathrm{g}-\mathrm{cat} / \mathrm{min})}$
11Co-IW-B

0.505

F4

\section{$\frac{\mathrm{I} I \mathrm{II} I \mathrm{I}^{\prime}}{(\mu \mathrm{mol} / \mathrm{g} \text {-cat } / \mathrm{min})} \quad \mathrm{II} / \mathrm{I}$}

$\begin{array}{lll}0 & 3.0 & 0\end{array}$

\section{2}

0.2

\section{2}

0.8

0.1

0.10 .6

13.7

21.4

0.2

1.6

2.1

0.7

0.1

$0 \quad 0 \quad 0$

$\begin{array}{lll}0 & 0 & 0\end{array}$

$\begin{array}{lll}9.7 & 15.8 & 10.6\end{array}$

$\begin{array}{lll}2.0 & 2.8 & 2.0\end{array}$

$\begin{array}{lll}0.8 & 1.1 & 0.9\end{array}$

$\begin{array}{lll}20.4 & 40.3 & 20.8\end{array}$

$\begin{array}{ll}0 & 2.0\end{array}$

0

0

0

0.2

0.3

0.1

0.6

0.0

0.7

0.8

6.0

$-$

\section{6}

1.4

1.4

2.0

28.9

$14.1 \quad 29.6$

0.5

0.1

$\begin{array}{ll}0.0 & 0.1\end{array}$

0.0

3.0

$3.1 \quad 3.9$

1.0

1.6

$1.5 \quad 1.6$

0.9

0.4

1.4

0.4

3.5

0.2

0.1

0.2

0.5

0

9.5

$25.1 \quad 13.4$

2.6

2.0

$3.8 \quad 2.3$

1.9

$\begin{array}{lll}0.9 & 1.9 & 1.1\end{array}$

2.1

18.8

$22.6 \quad 22.3$

1.2

$\begin{array}{lll}0 & 3.4 & 0\end{array}$

$\begin{array}{lll}0 & 0.3 & 0\end{array}$

0

0.50

0

0.0

$-100$

a: 500 psig, $290^{\circ} \mathrm{C}, \mathrm{H}_{2}: \mathrm{CO}=2, \mathrm{GHSV}=6,000 \sim 60,000 \mathrm{hr}^{-1}$.

b: Refer section 3.1.1 and 3.1.2 for the descriptions of catalysts and reduction treatments.

c: Figures presented in Appendix $\mathrm{F}$.

d: I : prior to $\mathrm{CH}_{3} \mathrm{NO}_{2}$ addition, I': post to $\mathrm{CH}_{3} \mathrm{NO}_{2}$ addition, II: during $\mathrm{CH}_{3} \mathrm{NO}_{2}$ addition,

e: $\mathrm{N}$ conversion from $\mathrm{CH}_{3} \mathrm{NO}_{2}$ to methylamines and $\mathrm{NH}_{3}$. "-": N/A. 
Table 16 Effects of $\mathrm{CH}_{3} \mathrm{NO}_{2}$. Addition to $\mathrm{H}_{2} / \mathrm{CO}$ on the $\mathrm{CO}$ Hydrogenation a over 00Co-IW-A, 05Co-IW-A, 11Co-IW-A\&B and 11Co-CP-A\&B (continued)

Catalysts:

g-cat/bed:

Figure \#:

Steady States ${ }^{d}$

$\mathrm{CH}_{3} \mathrm{NO}_{2}$ :

PRODUCTS:

Methanol

Dimethyl ether

Ethanol

n-Propanol

n-Butanol

n-Pentanol

n-Hexanol

Methane

$\mathrm{C}_{2} \mathrm{HCs}$

$\mathrm{C}_{3}+\mathrm{HCs}$

$\mathrm{CO}_{2}$

$\left(\mathrm{CH}_{3}\right)_{3} \mathrm{~N}$

$\left(\mathrm{CH}_{3}\right)_{2} \mathrm{NH}$

$\mathrm{CH}_{3} \mathrm{NH}_{2}$

$\mathrm{NH}_{3}$

N Conversion, \%e:
11 Co-CP-A

0.464

F5

$\left.\frac{\mathrm{I}}{(\mu \mathrm{mol} / \mathrm{g} \text {-cat } / \mathrm{min})} \quad \mathrm{I}\right) / \mathrm{I}$

$\begin{array}{lll}0 & 3.2 & 0\end{array}$

\section{$\begin{array}{lll}4.6 & 2.7 & 5.2\end{array}$}

0.6

$0 \quad 0 \quad 0$

$2.6 \quad 1.7$

3.1

$0.9 \quad 0.7$

1.3

$\begin{array}{ll}0.5 & 0.9\end{array}$

0.7

$\begin{array}{lll}0 & 0 & 0\end{array}$

$\begin{array}{lll}0 & 0 & 0\end{array}$

$4.5 \quad 3.6$

5.8

$1.3 \quad 1.0$

2.1

$\begin{array}{lll}1.9 & 1.2 & 3.0\end{array}$

31.6

$$
0
$$

20.5

43.4

0.50

$\begin{array}{lll}0 & 0.0 & 0\end{array}$

0

0

$0.3 \quad 0$

0.2

\begin{tabular}{l}
$-\quad 31$ \\
\hline
\end{tabular}

0.7

0.8

1.8

\section{8}

0.8

0.6

0.6
11Co-CP-B

0.250

F6 $\frac{\mathrm{I} I I}{(\mu \mathrm{mol} / \mathrm{g} \text {-cat } / \mathrm{min})}$

II/I 0

6.0

7.2

$\begin{array}{ll}4.7 & 9.3\end{array}$

0.6

$\begin{array}{lll}0 & 0 & 0\end{array}$

$-$

5.0

3.0

6.8

0.6

1.8

1.1

2.1

0.6

$\begin{array}{lll}1.6 & 1.1 & 1.7\end{array}$

0.7

$1.2 \quad 1.0$

1.3

0.8

1.1

0.9

1.3

0.8

$\begin{array}{lll}13.0 & 13.3 & 15.6\end{array}$

1.0

$3.3 \quad 3.5$

4.8

1.1

3.9

$3.8 \quad 5.9$

1.0

$\begin{array}{lll}55.5 & 58.0 & 76.8\end{array}$

1.0

a: 500 psig, $290^{\circ} \mathrm{C}, \mathrm{H}_{2}: \mathrm{CO}=2, \mathrm{GHSV}=6,000 \sim 60,000 \mathrm{hr}^{-1}$.

b: Refer section 3.1.1 and 3.1.2 for the descriptions of catalysts and reduction treatments.

c: Figures presented in Appendix $\mathrm{F}$.

d: I: prior to $\mathrm{CH}_{3} \mathrm{NO}_{2}$ addition, I': post to $\mathrm{CH}_{3} \mathrm{NO}_{2}$ addition, II: during $\mathrm{CH}_{3} \mathrm{NO}_{2}$ addition,

e: $\mathrm{N}$ conversion from $\mathrm{CH}_{3} \mathrm{NO}_{2}$ to methylamines and $\mathrm{NH}_{3}$. "-": N/A. 
05Co-IW and 11Co-IW samples but not with 11Co-CP samples.

$00 \mathrm{Co}-\mathrm{IW}-\mathrm{A}$ and $05 \mathrm{Co}-\mathrm{IW}-\mathrm{A}$

Over 00Co-IW-A, a large increase in $\mathrm{CO}_{2}$, from about 20 to $130 \mu \mathrm{mol} / \mathrm{g}$ cat/ $\mathrm{min}$, was observed upon the addition of $\mathrm{CH}_{3} \mathrm{NO}_{2}$ and the formation rate of methanol was doubled; the rates of dimethylether, ethanol, propanol and hydrocarbons were not significantly affected; methylamines and $\mathrm{NH}_{3}$ were formed with nearly $80 \%$ nitrogen conversion to trimethylamine.

Over 05 Co-IW-A, the formation rates of $C_{1}-C_{3}$ alcohols were each suppressed to a similar extent, i.e., by $40 \sim 50 \%$; the formation rates of hydrocarbons were hardly affected except for approximately $20 \%$ increase in $\mathrm{CH}_{4} ; \mathrm{CO}_{2}$ increased from 16 to $31 \mu \mathrm{mol} / \mathrm{g}$-cat/min; and methylamines were formed with $\sim 90 \%$ nitrogen conversion to trimethylamine.

\section{$11 \mathrm{Co}_{\mathrm{IW}} \mathrm{A}$ and $11 \mathrm{Co}-\mathrm{IW}-\mathrm{B}$}

Over 11Co-IW-A, the formation rates of methanol, ethanol and propanol were each suppressed by $\sim 40 \%, \sim 30 \%$ and $\sim 20 \%$ respectively while butanol was promoted to the same level as propanol formation; the formation rates of all hydrocarbons were enhanced by $40 \sim 60 \% ; \mathrm{CO}_{2}$ increased from $\sim 20$ to $\sim 40 \mu \mathrm{mol} / \mathrm{g}$-cat/min; methylamines and a very small amount of $\mathrm{NH}_{3}$ were formed with about $70 \%$ nitrogen conversion to trimethylamine.

Over 11 Co-IW-B, the formation rate of methanol was suppressed by $50 \%$ and butanol was promoted to the level of propanol formation while the rates of ethanol and propanol were hardly affected and pentanol dropped by half; the formation rates of hydrocarbons doubled for $\mathrm{C}_{2}$ and tripled for $\mathrm{CH}_{4} ; \mathrm{CO}_{2}$ formation was not affected; and nitrogen conversion to trimethylamine was above $80 \%$. 


\section{$11 \mathrm{C}_{0}-\mathrm{CP}-\mathrm{A}$ and $11 \mathrm{Co}-\mathrm{CP}-\mathrm{B}$}

Over $11 \mathrm{Co}-\mathrm{CP}-\mathrm{A}$, the formation rates of methanol, ethanol and propanol were suppressed by about $40 \%, 30 \%$ and $20 \%$ respectively while butanol was promoted to the level of propanol formation; the formation rates of hydrocarbons were also suppressed by $20 \sim 40 \% ; \mathrm{CO}_{2}$ decreased by about $\sim 40 \%$; small amounts of methylamines and $\mathrm{NH}_{3}$ were formed with only $\sim 16 \%$ nitrogen conversion to trimethylamine.

Over $11 \mathrm{Co}-\mathrm{CP}-\mathrm{B}$, the formation rates of $\mathrm{C}_{1} \sim \mathrm{C}_{3}$ alcohols were each suppressed by $\sim 40 \%$ while butanol suppressed by $\sim 30 \%$ and $C_{4}$ and $C_{5}$ alcohols by $20 \%$; the formation rates of hydrocarbons as well as $\mathrm{CO}_{2}$ were not affected; small amounts of methylamines and $\mathrm{NH}_{3}$ were formed with less than $20 \%$ nitrogen conversion to trimethylamine.

\subsection{Discussion}

\subsubsection{Co-IW-A and 05Co-IW-A}

In the previous studies using probe molecule addition to $\mathrm{CO}$ hydrogenation over supported $\mathrm{Ru}$ catalysts(25-27), $\mathrm{CH}_{3} \mathrm{NO}_{2}$ was found to generate $\mathrm{CH}_{\mathrm{x}}(\mathrm{x} \leq 3)$ surface species via $\mathrm{C}-\mathrm{N}$ bond cleavage, and these $\mathrm{CH}_{\mathrm{x}}(\mathrm{x} \leq 3)$ surface species acted as chain growth intermediates in the formation of $\mathrm{C}_{2^{+}}$ hydrocarbons. The fact that the addition of $\mathrm{CH}_{3} \mathrm{NO}_{2}$ to the $\mathrm{CO}$ hydrogenation over $00 \mathrm{Co}-\mathrm{IW}$-A resulted in complete conversion of nitrogen into methylamines without promoting the formation of hydrocarbons indicates that the $\mathrm{CH}_{x}(x \leq 3)$ surface species were not selectively formed from $\mathrm{CH}_{3} \mathrm{NO}_{2}$ over 
$\mathrm{Cu} / \mathrm{ZnO}$. The formation of methylamines suggests a route through reduction of $\mathrm{CH}_{3} \mathrm{NO}_{2}$ to $\mathrm{CH}_{3} \mathrm{NH}_{2}$ followed by alkylation. The high conversion of $\mathrm{N}$ from $\mathrm{CH}_{3} \mathrm{NO}_{2}$ into $\left(\mathrm{CH}_{3}\right)_{3} \mathrm{~N}$ indicates that $\mathrm{C}$ in $\left(\mathrm{CH}_{3}\right)_{3} \mathrm{~N}$ came from $\mathrm{CO}$. As supporting evidence, the low conversion of nitrogen from $\mathrm{CH}_{3} \mathrm{NO}_{2}$ to $\mathrm{NH}_{3}$ suggests that disproportionation of methylamines was not the dominant pathway for the formation of $\left(\mathrm{CH}_{3}\right)_{3} \mathrm{~N}$ as well as $\left(\mathrm{CH}_{3}\right)_{2} \mathrm{NH}$. This observation is consistent with the mechanism of methanol synthesis from $\mathrm{CO} / \mathrm{H}_{2}$ over $\mathrm{Cu} / \mathrm{ZnO}$ catalyst revealed by a chemical trapping study(82). In that study, it was concluded that the lower substituted amines, $R\left(R^{\prime}\right) N H$, trapped the aldehydic methanol intermediate, $\mathrm{CH}_{\mathrm{x}} \mathrm{O}(\mathrm{x}=1,2)$, to form higher substituted amines, $\mathrm{R}\left(\mathrm{R}^{\prime}\right) \mathrm{NCH}_{3}$, i.e.

$$
\mathrm{R}\left(\mathrm{R}^{\prime}\right) \mathrm{NH}+\{[\mathrm{HCO}] \stackrel{[\mathrm{H}]}{=}[\mathrm{HCHO}]\} \stackrel{[\mathrm{H}]}{\rightarrow} \mathrm{R}\left(\mathrm{R}^{\prime}\right) \mathrm{NCH}_{3}+\mathrm{H}_{2} \mathrm{O}
$$

It is also consistent with the current understanding of the mechanism of amine alkylation from alcohol and amine or ammonia over $\mathrm{Cu}$ catalysts(103), in which the $\mathrm{N}$-containing species react with the surface aldehydic species formed from decomposition of the alcohol to give the alkylation products. Therefore, the involvement of $\mathrm{CO}$ in the formation of $\left(\mathrm{CH}_{3}\right)_{3} \mathrm{~N}$ during $\mathrm{CH}_{3} \mathrm{NO}_{2}$ addition to $\mathrm{CO} / \mathrm{H}_{2}$ over $00 \mathrm{Co}$-IW-A suggests that the $\mathrm{CH}_{3} \mathrm{NH}_{2}$ formed from $\mathrm{CH}_{3} \mathrm{NO}_{2}$ reduction diverted methanol intermediate to form higher substituted methylamines.

Knowing that $\mathrm{Cu}$ is a very active WGS catalyst, the striking increase in $\mathrm{CO}_{2}$ upon the addition of $\mathrm{CH}_{3} \mathrm{NO}_{2}$ over 00Co-IW-A suggests that in addition to converting all the oxygen from $\mathrm{CH}_{3} \mathrm{NO}_{2}$ to $\mathrm{CO}_{2}$ on $\mathrm{Cu}$ the $\mathrm{H}_{2} \mathrm{O}$ formed 
from the pathway of trimethylamine formation (6-1) was also converted to $\mathrm{CO}_{2}$. The promotion effect of this large increase in $\mathrm{CO}_{2}$ on methanol formation over 00Co-IW-A (shown by Table 16 and Figure F1 (a \& c)) was consistent with the result of $\mathrm{CO}_{2}$ addition to $\mathrm{CO}$ hydrogenation over $00 \mathrm{Co}$ IW-A (see Figure 20). The increase in the formation rate of methanol was so large, by more than $100 \%$, that the suppression effect on methanol formation by diverting methanol intermediate to form higher substituted methylamines became difficult to deconvolute.

The observation of complete conversion of $\mathrm{CH}_{3} \mathrm{NO}_{2}$ into methylamines with $\left(\mathrm{CH}_{3}\right)_{3} \mathrm{~N}$ as the major product over $05 \mathrm{Co}-\mathrm{IW}-\mathrm{A}$ resembles the observation over 00Co-IW-A which as discussed above indicates a significant involvement of $\mathrm{C}$ from $\mathrm{CO}$ in the formation of $\left(\mathrm{CH}_{3}\right)_{3} \mathrm{~N}$. The suppression of methanol upon $\mathrm{CH}_{3} \mathrm{NO}_{2}$ addition over 05Co-IW-A provided strong further evidence that the formation of the higher substituted methylamines diverted the methanol intermediate. As shown in chapter 5.0, the addition of cobalt on $\mathrm{Cu} / \mathrm{ZnO}$ suppressed the promotion effect of $\mathrm{CO}_{2}$ on methanol formation and hence the diversion of the methanol intermediate could be readily observed.

The intriguing point raised from the result over 05Co-IW-A is that upon $\mathrm{CH}_{3} \mathrm{NO}_{2}$ addition ethanol and propanol were all suppressed simultaneously and to similar extents as methanol while the formation of $\mathrm{C}_{2}+$ hydrocarbons was not affected. This leads to the suggestion that the methanol intermediate formed from $\mathrm{CO} / \mathrm{H}_{2},[\mathrm{HCO}]$ or $[\mathrm{HCHO}]$ as shown in $(6-1)$, was also involved in the pathway of $\mathrm{C}_{2}$ alcohol formation. A reaction scheme shown in Figure 21 is proposed to describe the interaction of $\mathrm{CH}_{3} \mathrm{NO}_{2}$ with the common intermediate for the formation of alcohols in the $\mathrm{CO}$ hydrogenation reaction 


$\begin{array}{cc}\mathrm{CH}_{3} \mathrm{NO}_{2} & \mathrm{CO}+\mathrm{H}_{2} \\ {[\mathrm{CO}] \downarrow[\mathrm{H}]} & \downarrow \\ \mathrm{CH}_{3} \mathrm{NH}_{2} & +\quad[\mathrm{HCO}=\mathrm{[H}] \\ + & \downarrow[\mathrm{HCHO}] \stackrel{-\mathrm{H} 2 \mathrm{O}}{\rightarrow}\left(\mathrm{CH}_{3}\right)_{3} \mathrm{~N}+\left(\mathrm{CH}_{3}\right)_{2} \mathrm{NH} \\ \mathrm{H}_{2} \mathrm{O} / \mathrm{CO}_{2} & \mathrm{CH}_{3} \mathrm{OH} \\ & \mathrm{CH}_{3}-\mathrm{CH}_{2} \mathrm{OH} \\ & \mathrm{CH}_{3} \mathrm{CH}_{2}-\mathrm{CH}_{2} \mathrm{OH}\end{array}$

Figure 21 Proposed Reaction Scheme for the Interaction of $\mathrm{CH}_{3} \mathrm{NO}_{2}$ with the Formation of Alcohols from $\mathrm{CO} / \mathrm{H}_{2}$ on a Co Modified $\mathrm{Cu}$ Catalyst Surface

over these Co modified $\mathrm{Cu}$ based catalysts.

As indicated by the characterization and $\mathrm{CO}$ hydrogenation results, the very finely dispersed $\mathrm{Co}^{\circ}$ on copper metal surface of $05 \mathrm{Co}-\mathrm{IW}-\mathrm{A}$ did not promote the formation rates of $\mathrm{C}_{2}$ alcohols but significantly suppressed the formation rate of methanol as well as the promotional effect of $\mathrm{CO}_{2}$ on methanol formation. This suggested that the modification of copper metal surface by very finely dispersed $\mathrm{Co}^{\circ}$ did not form new active sites for $\mathrm{C}_{2}{ }^{+}$ alcohol synthesis hence did not change the dominant pathway of $\mathrm{C}_{2}+$ alcohol formation over 05Co-IW-A from over 00Co-IW-A. Therefore, the reaction scheme proposed in Figure 21 is valid for both over copper metal surface along, i.e. $00 \mathrm{Co}-\mathrm{IW}-\mathrm{A}$, and over the copper metal surface modified by very 
finely dispersed $\mathrm{Co}^{\circ}$, i.e. $05 \mathrm{Co}-\mathrm{IW}$-A.

The fact that over 00Co-IW-A the increase in $\mathrm{CO}_{2}$ did not promote $\mathrm{C}_{2}+$ alcohol formation but only methanol, which was shown by both Figure 20 and Figure $\mathrm{F} 1$ (a), suggests that the promotion of methanol formation by $\mathrm{CO}_{2}$ on $\mathrm{Cu} / \mathrm{ZnO}$ occurred via a different intermediate, such as surface formate [HCOO] $(51,52,79,83)$, to the dominant one formed from $\mathrm{CO} / \mathrm{H}_{2}$. This also provides a supporting evidence that the pathway of methanol formation from $\mathrm{CO}_{2} / \mathrm{H}_{2}$ was different to from $\mathrm{CO} / \mathrm{H}_{2}$, which has been argued in the literature.

\subsubsection{Co-IW-A, 11Co-IW-B}

Over 11Co-IW-A, the suppression of methanol with high $\mathrm{N}$ conversion to trimethylamine and an increase in $\mathrm{CO}_{2}$ upon the addition of $\mathrm{CH}_{3} \mathrm{NO}_{2}$ were similar to the effects observed over 05Co-IW-A. This suggests that similar reaction pathways as shown in Figure 21 occurred over 11Co-IW-A. The high conversion of $\mathrm{N}$ to methylamines could be mainly attributed to the presence of $\mathrm{Cu}$ metal sites which as discussed above was very active for alkylation of $\mathrm{N}$ - species.

However, different from the observation over 05Co-IW-A, $\mathrm{CH}_{3} \mathrm{NO}_{2}$ addition over 11Co-IW-A caused significant increase in the formation rates of hydrocarbons and promoted butanol formation while ethanol and propanol were suppressed to lesser extent than over $05 \mathrm{Co}-\mathrm{IW}-\mathrm{A}$. This suggests that other reaction pathways might be important over 11Co-IW. Considering the similarity of $\mathrm{Co}^{\circ}$ and $\mathrm{Ru}^{\circ}$ for hydrocarbon synthesis, the increase in the 
formation rates of hydrocarbons with $\mathrm{CH}_{3} \mathrm{NO}_{2}$ addition suggests that some $\mathrm{CH}_{\mathrm{x}}(\mathrm{x} \leq 3)$ surface species were formed from $\mathrm{CH}_{3} \mathrm{NO}_{2}$ over $11 \mathrm{Co}-\mathrm{IW}-\mathrm{A}$. Chain growth of these $\mathrm{CH}_{x}$ species to produce $\mathrm{C}_{2^{+}}$hydrocarbons could occur over the $\mathrm{Co}^{\circ}$ similar to $\mathrm{Ru}$. And, formation of butanol at the expense of ethanol and propanol could also be related to coupling of $\mathrm{CH}_{\mathrm{x}}$ species. This suggestion is, in fact, supported by the characterization and $\mathrm{CO}$ hydrogenation reaction results that, compared to 05Co-IW-A, the higher formation rates of $\mathrm{C}_{2}+$ alcohols over $11 \mathrm{Co}-\mathrm{IW}-\mathrm{B}$ was due to a higher amount of $\mathrm{Co}^{\circ}$ on $\mathrm{Cu}^{\circ}$ on $11 \mathrm{Co}-$ IW-B. It is reasonable to assume that the behavior of Co was closer to $\mathrm{Ru}$ with increased amount of $\mathrm{Co}^{\circ}$ on $\mathrm{Cu}^{\circ}$ (or larger particle size of $\mathrm{Co}^{\circ}$ on $\mathrm{Cu}^{\circ}$ ) since it should have less influence of copper metal. Consequently, the increase in butanol formation rate and the relatively less decrease in ethanol and propanol with $\mathrm{CH}_{3} \mathrm{NO}_{2}$ addition suggest that the $\mathrm{CH}_{x}(x \leq 3)$ surface species formed from $\mathrm{CH}_{3} \mathrm{NO}_{2}$ also participated in the formation of $\mathrm{C}_{2}+$ alcohols.

The fact that $\mathrm{CH}_{3} \mathrm{NO}_{2}$ addition over 11Co-IW-B also showed the promotion effect on the formation of hydrocarbons and butanol with suppression of methanol formation and little effect on ethanol and propanol formation provided supporting evidence that some $\mathrm{CH}_{\mathrm{x}}(\mathrm{x} \leq 3)$ surface species were formed from $\mathrm{CH}_{3} \mathrm{NO}_{2}$ on the $\mathrm{Co}^{\circ}$ similar to $\mathrm{Ru}$ and also participated in the formation of $\mathrm{C}_{2}$ alcohols while $\mathrm{N}$ from $\mathrm{CH}_{3} \mathrm{NO}_{2}$ was competitively converted to methylamines, mainly $\left(\mathrm{CH}_{3}\right)_{3} \mathrm{~N}$. The minor effect of $\mathrm{CH}_{3} \mathrm{NO}_{2}$ addition on $\mathrm{CO}_{2}$ formation over 11Co-IW-B could be due to the increased amount of cobalt on the catalyst surface which reduced the water-gas shift capability of $\mathrm{Cu}^{\circ}$.

Considering the chain termination step, $\mathrm{CO}$ insertion into the alkyl 
group $(22,98)$ and combination of surface formyl, [HCO], or surface formate, [HCOO], with the surface alkyl group ${ }^{(22)}$ have been proposed. There is little experimental evidence in the literature that can distinguish the proposed chain termination steps for the formation of $\mathrm{C}_{2}+$ alcohols over $\mathrm{Co}-\mathrm{Cu}$ based catalysts. As suggested by the interaction of $\mathrm{CH}_{3} \mathrm{NO}_{2}$ with the formation of alcohols and hydrocarbons over 00Co-IW, 05Co-IW and 11Co-IW samples, both the aldehydic methanol intermediate and the $\mathrm{CH}_{\mathrm{x}}$ species were involved in the formation of $\mathrm{C}_{2^{+}}$alcohols. It, therefore, suggests that combination of aldehydic surface $\mathrm{C}_{1}$ species, [ $\left.\mathrm{HCO}\right]$ or $[\mathrm{HCHO}]$, with the surface alkyl group could be the termination step in the formation of $\mathrm{C}_{2}$ alcohols. The results of catalyst characterization and $\mathrm{CO}$ hydrogenation studies were consistent with this proposal in the sense that proper size of $\mathrm{Co}^{\circ}$ and surface copper metal would provide the opportunity or possibility for both chain growth on $\mathrm{Co}^{\circ}$ and termination by the methanol intermediate on $\mathrm{Cu}^{\circ}$.

\subsubsection{Co-CP-A and 11Co-CP-B}

The low conversion of $\mathrm{CH}_{3} \mathrm{NO}_{2}$ to methylamines and ammonia over $11 \mathrm{Co}-\mathrm{CP}$ samples could be due to lack of copper metal sites that were not strongly affected by cobalt. This is consistent with the relatively lower composition of copper in $11 \mathrm{Co}-\mathrm{CP}$ samples than in 11Co-IW and the characterization results that indicated more interaction between cobalt and copper in the $11 \mathrm{Co}-\mathrm{CP}$ samples than in 11Co-IW. As a result, the imbalance of $\mathrm{N}$ over the $11 \mathrm{Co}-\mathrm{CP}$ samples might be an indication of surface holdup of $\mathrm{N}$ species. The surface holdup of $\mathrm{N}$ might occur by forming nitrides, $\mathrm{Cu}_{3} \mathrm{~N}$ or 
$\mathrm{Co}_{3} \mathrm{~N}_{2}$, with the very finely dispersed metal particles that had strong influence of metal oxides, $\mathrm{Co}_{3} \mathrm{O}_{4} / \mathrm{ZnO} / \mathrm{Al}_{2} \mathrm{O}_{3}$. It might also be possible that a small portion of nitrogen was converted to $\mathrm{N}_{2}$ with a concentration below the detectability of the system. This is discussed further below.

Over $11 \mathrm{Co}-\mathrm{CP}-\mathrm{A}, 30 \% \mathrm{~N}$ conversion to the $\left(\mathrm{CH}_{3}\right)_{3-\mathrm{x}} \mathrm{NH}_{\mathrm{x}}$ products was detected with $\mathrm{CH}_{3} \mathrm{NO}_{2}$ added at $3 \mu \mathrm{mol} / \mathrm{g}$-cat $/ \mathrm{min}$ for about 4 hours. Assuming that all the undetected $\mathrm{N}$ reacted with copper to form $\mathrm{Cu}_{3} \mathrm{~N}$, it would convert $34 \%$ of the copper atoms in per gram sample within 4 hours. This significant loss of $\mathrm{Cu}^{\circ}$ would be able to be observed by XRD pattern of copper metal crystalline. Therefore, the fact that the XRD results (see Figure $\mathrm{Al}$ (a)) did not show decrease in $\mathrm{Cu}^{\circ}$ particle size neither detection of $\mathrm{Cu}_{3} \mathrm{~N}$ eliminated the possibility that the $\mathrm{N}$-imbalance was due to formation of $\mathrm{Cu}_{3} \mathrm{~N}$. If it is assumed that all the undetected $\mathrm{N}$ reacted with $\mathrm{Co}^{\circ}$ to form $\mathrm{Co}_{3} \mathrm{~N}_{2}$, considering $42 \%$ reduction of cobalt in $11 \mathrm{Co}-\mathrm{CP}-\mathrm{A}$ (see section 4.1.2.1), it would convert all the $\mathrm{Co}^{\circ}$ in 4 hours. This is contradictory to the fact that butanol was promoted and formation rates of hydrocarbons reached new steady state about an hour after adding $\mathrm{CH}_{3} \mathrm{NO}_{2}$, and therefore is eliminated from consideration. Consequently, formation of $\mathrm{N}_{2}$ seems more likely. An explanation for the suppression of hydrocarbon formation could be that surface $\mathrm{N}^{*}$ was formed via $\mathrm{C}-\mathrm{N}$ dissociation on $\mathrm{Co}^{\circ}$ but could not be readily converted to the $\left(\mathrm{CH}_{3}\right)_{3-\mathrm{x}} \mathrm{N}_{\mathrm{x}}$ products due to lack of $\mathrm{Co}^{\circ}$ sites or to $\mathrm{N}_{2}$ due to strong influence of $\mathrm{Cu}^{\circ}$ on very finely dispersed $\mathrm{Co}^{\circ}$ in contact with it, and remained on the surface with longer residence time. The surface $\mathrm{N}^{*}$ was converted to $\mathrm{N}_{2}$ at certain rate that kept part of the $\mathrm{Co}^{\circ}$ sites occupied by $\mathrm{N}^{*}$. The decrease in $\mathrm{CO}_{2}$ formation rate could be considered due to both the low 
water-gas shift activity of 11Co-IW-A and the decrease in hydrocarbon formation.

The suppression of $C_{1} \sim C_{3}$ alcohol formation could still be considered due to the formation of $\left(\mathrm{CH}_{3}\right)_{3-x} \mathrm{NH}_{x}, \mathrm{x}=0$ and 1 , through diversion of methanol intermediate as shown in Figure 21. The fact that over 11Co-IW-A butanol was promoted and the suppression extents of $C_{1} \sim C_{3}$ alcohols decreased in the order of methanol $>$ ethanol $>$ propanol suggested the occurrence of $\mathrm{C}-\mathrm{N}$ dissociation to form the $\mathrm{CH}_{\mathrm{x}}$ species on $\mathrm{Co}^{\circ}$ over $11 \mathrm{Co}-\mathrm{CP}-$ A. As discussed above, the C-N bond dissociation could leave $\mathrm{N}$ - species on the surface if the copper metal surround could not effectively convert them into $\left(\mathrm{CH}_{3}\right)_{3-\mathrm{x}} \mathrm{NH}_{\mathrm{x}}$ products.

Over $11 \mathrm{Co}-\mathrm{CP}-\mathrm{B}, 38 \% \mathrm{~N}$ conversion to the $\left(\mathrm{CH}_{3}\right)_{3-\mathrm{x}} \mathrm{NH}_{\mathrm{x}}$ products was detected with $\mathrm{CH}_{3} \mathrm{NO}_{2}$ added at $6 \mu \mathrm{mol} / \mathrm{g}$-cat/min for 7 8 hours. It would completely convert the copper in $11 \mathrm{Co}-\mathrm{CP}$ to $\mathrm{Cu}_{3} \mathrm{~N}$ in 7 hours and $\mathrm{Co}^{\circ}$ to $\mathrm{Co}_{3} \mathrm{~N}_{2}$ in 4 hours, which is contradictory to the XRD results and the steady formation rates of hydrocarbons. This again suggested that the undetected $\mathrm{N}$ during $\mathrm{CH}_{3} \mathrm{NO}_{2}$ addition over $11 \mathrm{Co}-\mathrm{CP}$ samples was converted to $\mathrm{N}_{2}$. As suggested by the characterization and $\mathrm{CO}$ hydrogenation results, the reduction extent of cobalt and atomic ratio of $\mathrm{Co}^{\circ} / \mathrm{Cu}^{\circ}$ were higher on $11 \mathrm{Co}-\mathrm{CP}-\mathrm{B}$ than on 11Co-CP-A. The fact that the formation rates of hydrocarbons were not changed with $\mathrm{CH}_{3} \mathrm{NO}_{2}$ addition could, then, be explained as that the conversion rate of surface $\mathrm{N}^{*}$ to $\mathrm{N} 2$ increased with the increase of surface $\mathrm{Co}^{\circ} / \mathrm{Cu}^{\circ}$ ratio. The suppression of all $\mathrm{C}_{1} \sim \mathrm{C}_{6}$ alcohols with $\mathrm{CH}_{3} \mathrm{NO}_{2}$ addition (by $\sim 40 \%$ for $C_{1} \sim C_{3}$ alcohols, $\sim 30 \%$ for butanol, $\sim 20 \%$ for pentanol and hexanol) was consistent with the suggested effect of diverting methanol 
intermediate by $\left(\mathrm{CH}_{3}\right)_{3-x} \mathrm{NH}_{x}, x \geq 1$, to form $\left(\mathrm{CH}_{3}\right)_{3-x} \mathrm{NH}_{x}, x \leq 2$, as discussed in section 6.2.1.

\subsection{Conclusions}

Over 00Co-IW, 05Co-IW and $11 \mathrm{Co}-\mathrm{IW}$ samples, the $\mathrm{CH}_{3} \mathrm{NO}_{2}$ added to $\mathrm{CO} / \mathrm{H}_{2}$ was readily reduced to $\mathrm{CH}_{3} \mathrm{NH}_{2}$ over copper metal sites and $\mathrm{CH}_{3} \mathrm{NH}_{2}$ further reacted with the aldehydic methanol intermediate formed from $\mathrm{CO}$ and $\mathrm{H}_{2}$ to form $\left(\mathrm{CH}_{3}\right)_{2} \mathrm{NH}$ and $\left(\mathrm{CH}_{3}\right)_{3} \mathrm{~N}$. The high conversion of $\mathrm{CH}_{3} \mathrm{NO}_{2}$ to $\left(\mathrm{CH}_{3}\right)_{3} \mathrm{~N}$ accompanied with the suppression of methanol and $\mathrm{C}_{2}+$ alcohol formation over $05 \mathrm{Co}-\mathrm{IW}$ and $11 \mathrm{Co}-\mathrm{IW}$ samples provided evidence suggesting that the aldehydic methanol intermediate formed from $\mathrm{CO}$ and $\mathrm{H}_{2}$ was also involved in the formation of $\mathrm{C}_{2}+$ alcohols.

The observation that over $11 \mathrm{Co}-\mathrm{IW}$ samples $\mathrm{CH}_{3} \mathrm{NO}_{2}$ addition promoted hydrocarbon and butanol formation with less suppression effect on ethanol and propanol formation than over $05 \mathrm{Co}-\mathrm{IW}$ suggested that some $\mathrm{CH}_{x}, \mathrm{x} \leq 3$, species were generated from $\mathrm{CH}_{3} \mathrm{NO}_{2}$ over $11 \mathrm{Co}-\mathrm{IW}$ and participated in the chain growth of both hydrocarbon and $\mathrm{C}_{2}+$ alcohol formation. Assisted by the results of characterization and $\mathrm{CO}$ hydrogenation, it was revealed that the $\mathrm{CH}_{x}, \mathrm{x} \leq 3$, species were not selectively generated from $\mathrm{CH}_{3} \mathrm{NO}_{2}$ on the surface with only very finely dispersed $\mathrm{Co}^{\circ}$ on copper metal surface (over 05Co-IWA), but competitively formed on the cobalt metal sites that was large enough to reduce the effect of $\mathrm{Cu}^{\circ}$ (over $11 \mathrm{Co}-\mathrm{TW}-\mathrm{A} \& \mathrm{~B}$ as well as $11 \mathrm{Co}-\mathrm{CP}-\mathrm{A} \& \mathrm{~B}$ ).

Combination of aldehydic surface species, [HCO] or [HCHO], with the surface alkyl group was proposed as the termination step in the formation of 
$\mathrm{C}_{2}+$ alcohols over Co-Cu based catalysts.

The nitrogen imbalance observed with $11 \mathrm{Co}-\mathrm{CP}$ samples was attributed to that lack of surface copper metal left the $\mathrm{N}$ - species generated from $\mathrm{CH}_{3} \mathrm{NO}_{2}$ unable to be readily converted to methylamines and ammonia and resulted in the conversion of the $\mathrm{N}$ from $\mathrm{CH}_{3} \mathrm{NO}_{2}$ into $\mathrm{N}_{2}$ which was beyond the detecting ability of the analysis method. 


\subsection{SUMMARY AND CONCLUSIONS}

$\mathrm{C}_{2}+$ alcohol formation from $\mathrm{CO}$ and $\mathrm{H}_{2}$ over $\mathrm{Cu}-\mathrm{Co}$ based catalysts was investigated by characterization, $\mathrm{CO}$ hydrogenation and in-situ $\mathrm{CH}_{3} \mathrm{NO}_{2}$ addition studies of $\mathrm{Cu}$-only and $\mathrm{Co}-\mathrm{Cu}$ based catalysts with differences in cobalt loading, preparation methods, and reduction treatment conditions. The experimental results provided mechanistic information from different aspects to delineate the states and roles of cobalt and copper in constructing the active sites for the synthesis of $\mathrm{C}_{2}+$ alcohols and the key surface intermediate(s) involved in the reaction pathway of $\mathrm{C}_{2^{+}}$alcohol formation. The major findings of this work are summarized below.

(1) The presence of cobalt in a $\mathrm{Cu} / \mathrm{ZnO}$ based catalyst drastically reduced the catalyst activity for methanol synthesis and suppressed the promotional effect of $\mathrm{CO}_{2}$ on methanol formation by blocking or deactivating the copper metal sites.

(2) Although cobalt in the states of $\mathrm{Co}^{\circ} / \mathrm{Co}^{2+} / \mathrm{Co}^{3+}$ played a key role in constructing the active sites for $\mathrm{C}_{2}$ alcohol synthesis, its presence alone was not sufficient for the promotion effect to occur.

(3) Proper local atomic ratio of $\mathrm{Co}^{\circ} / \mathrm{Cu}^{\circ}$ or contact between $\mathrm{Co}^{\circ}$ and $\mathrm{Cu}^{\circ}$ was suggested to be the key to creating the active sites, which could be obtained in increased amount by good mixing of the oxides of the key components through coprecipitation methods and by improving the reduction extent of cobalt in the resulting catalyst.

(4) Reduction using high $\mathrm{H}_{2}$ partial pressure, even pure $\mathrm{H}_{2}$, at temperatures above $300^{\circ} \mathrm{C}$, was found to have significant effects in improving 
the activity and selectivity of Co-Cu based catalysts for the synthesis of $\mathrm{C}_{2^{+}}$ alcohols without unacceptable increases in hydrocarbon formation.

(5) The interaction of $\mathrm{CH}_{3} \mathrm{NO}_{2}$ with the reaction network of $\mathrm{CO}$ hydrogenation over the $\mathrm{Cu}$ and $\mathrm{Co}-\mathrm{Cu}$ based catalysts suggested that the $\mathrm{C}_{1}$ aldehydic intermediate formed from $\mathrm{CO}$ and $\mathrm{H}_{2}$ was also involved in the formation of $\mathrm{C}_{2}+$ alcohols, and that $\mathrm{CH}_{\mathrm{x}}(\mathrm{x}<3)$ species was involved in the chain growth of $\mathrm{C}_{2}$ alcohol formation. 
APPENDIX A 


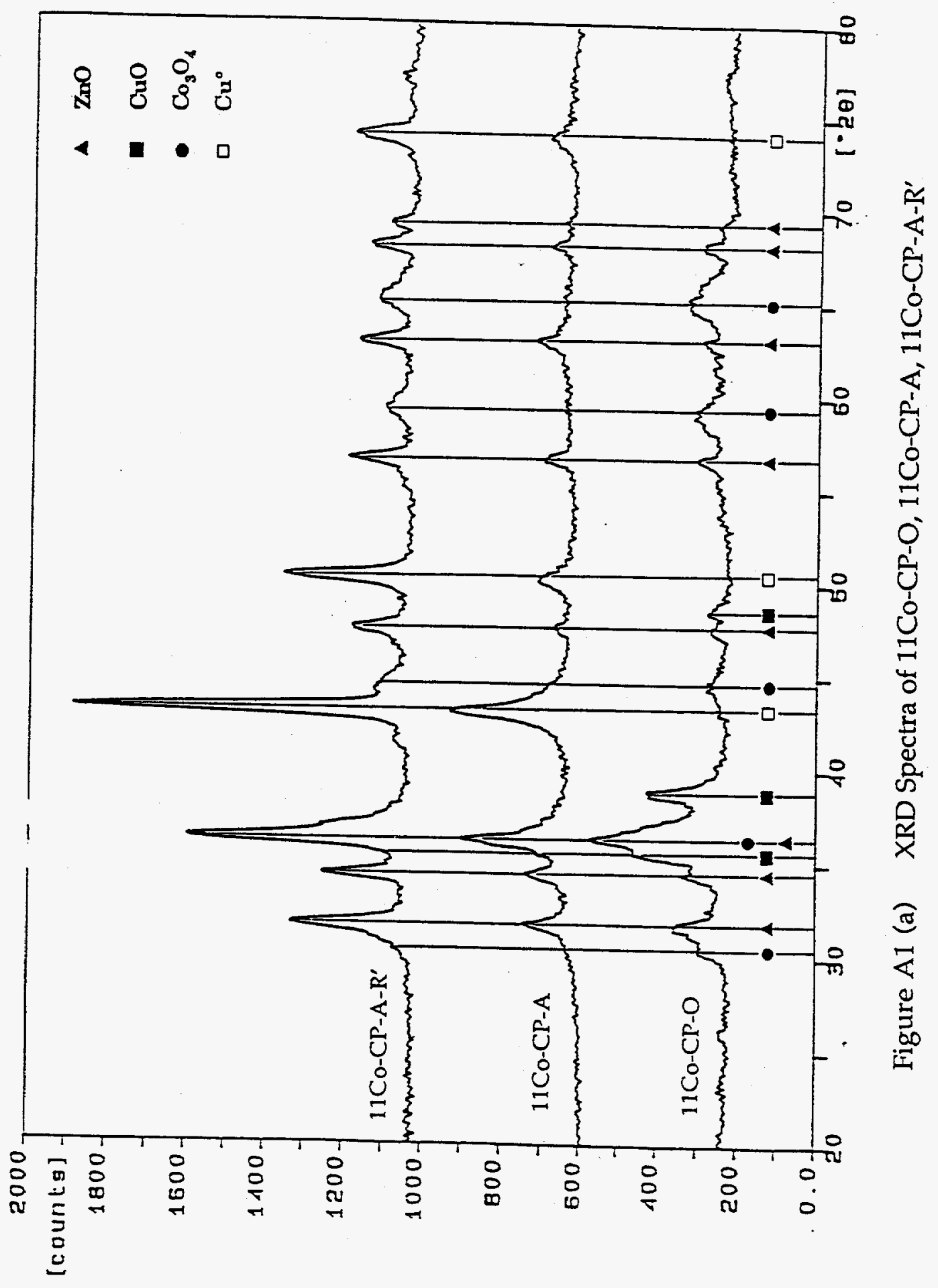




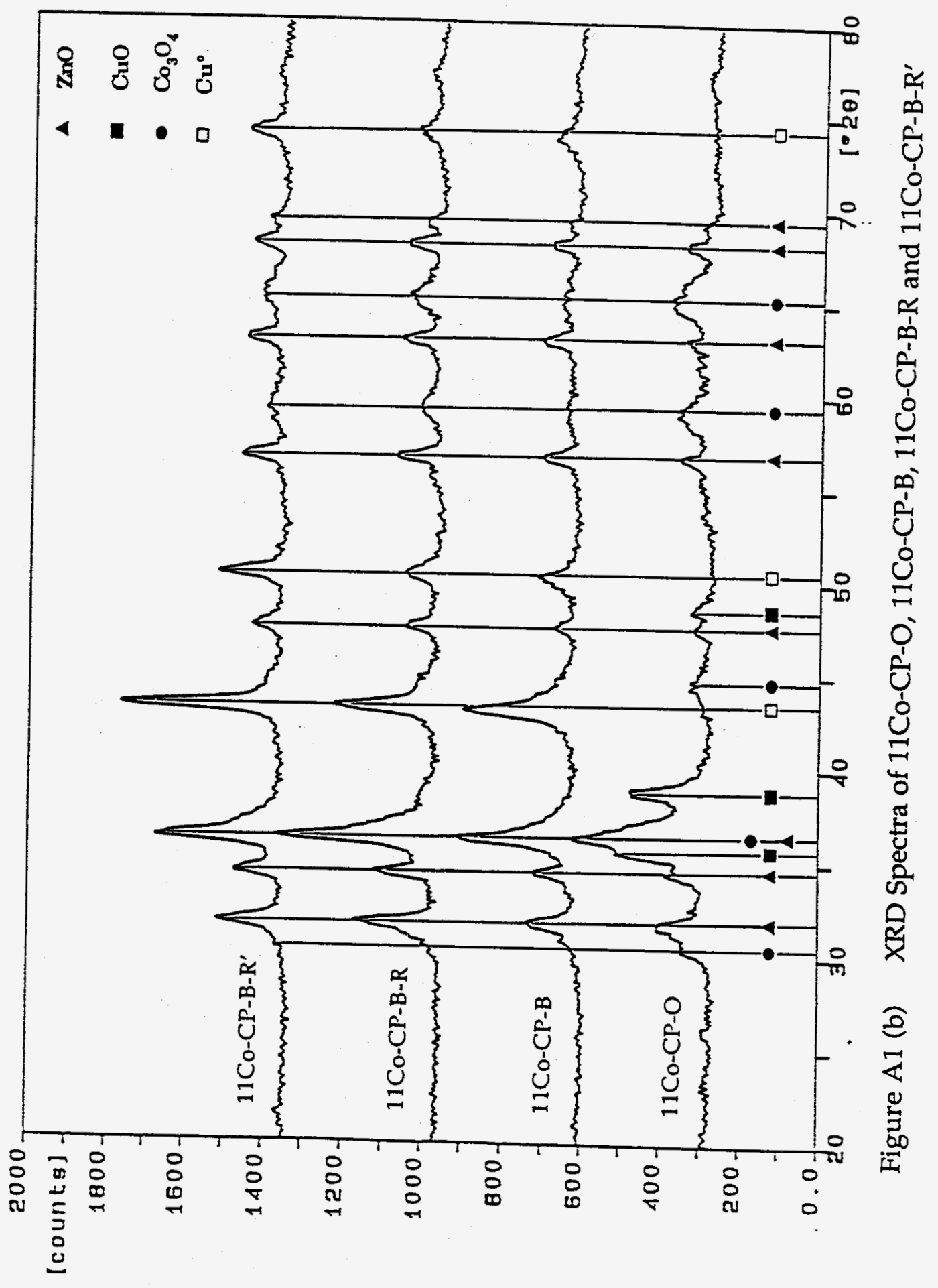




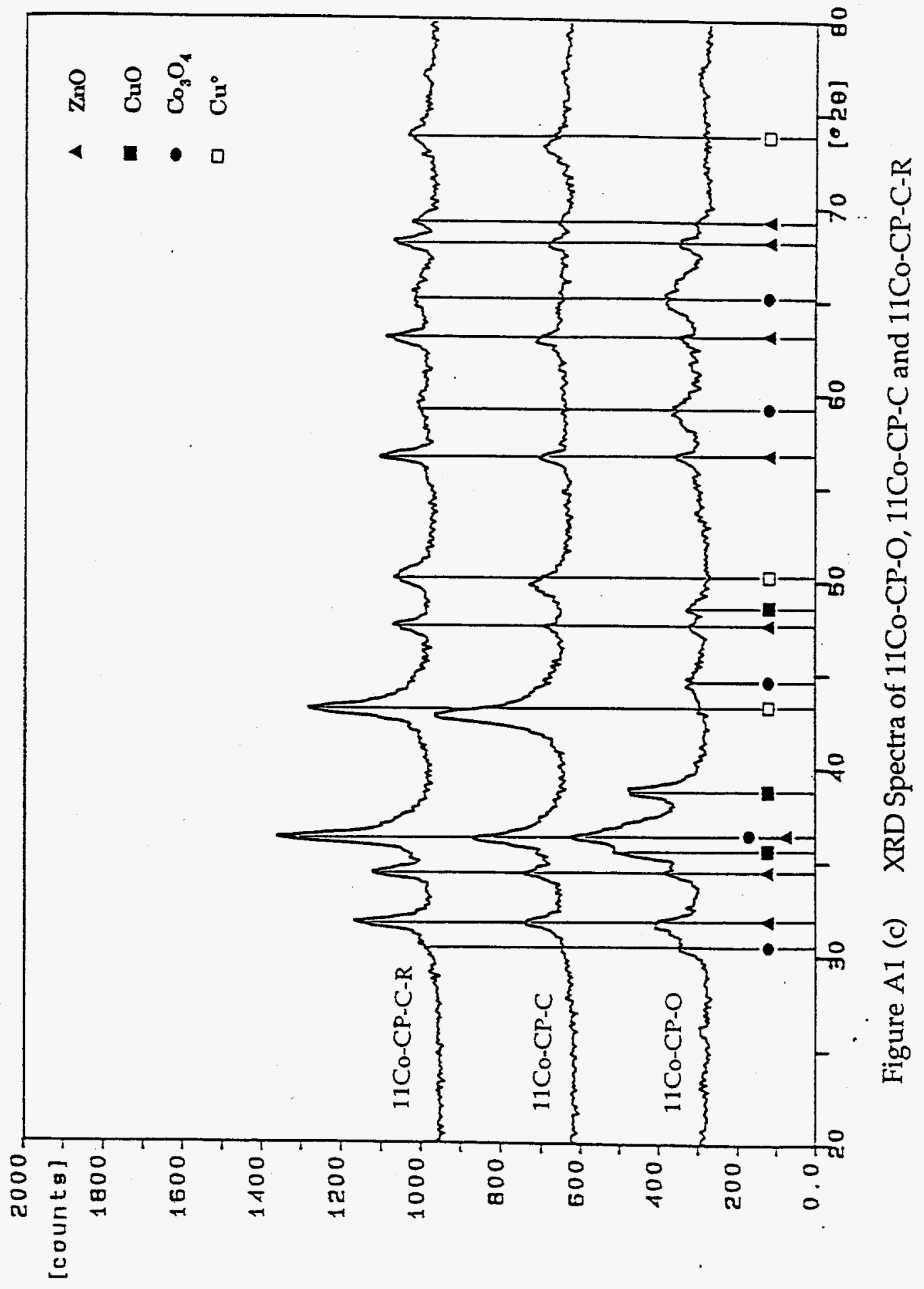




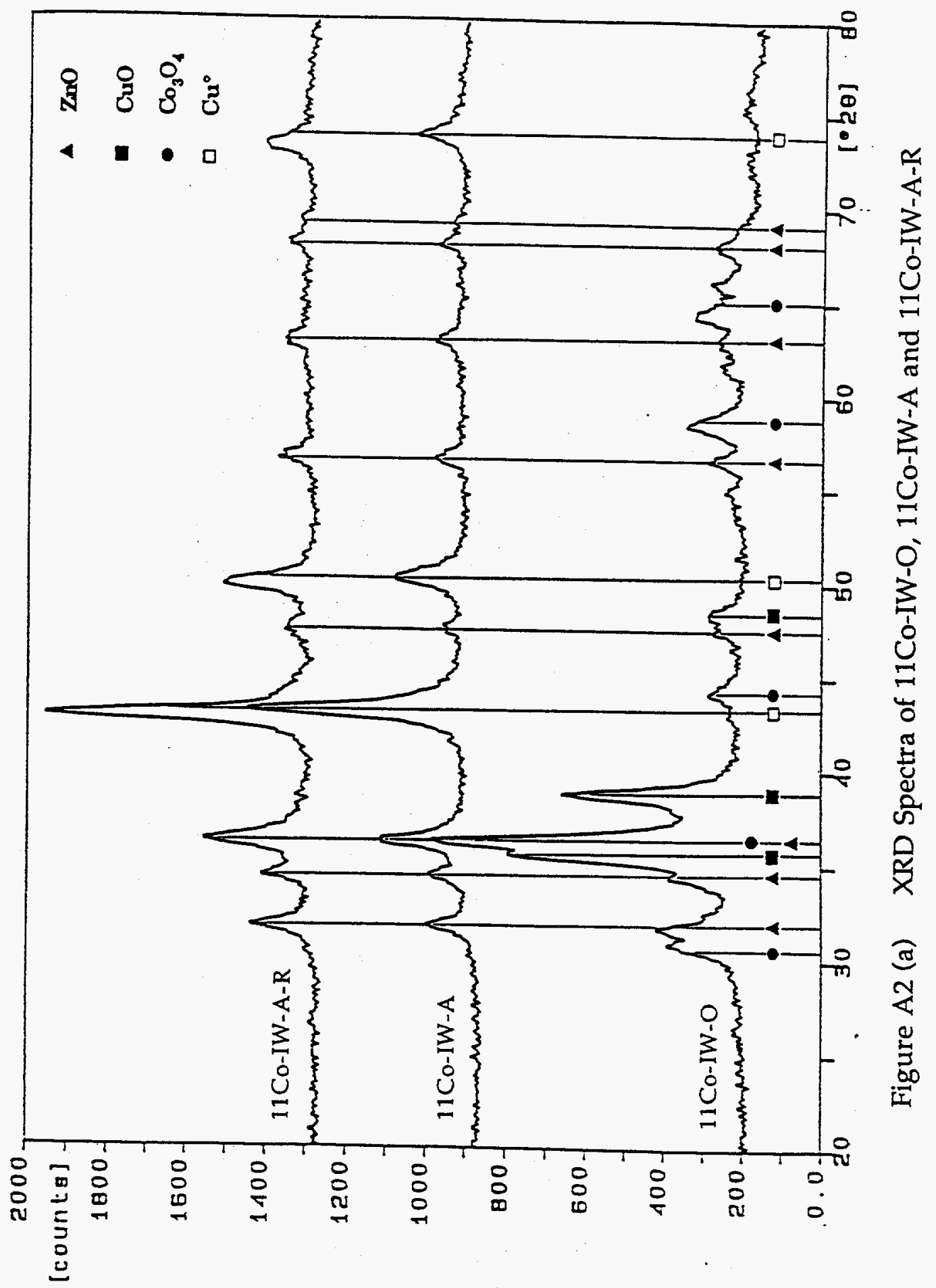




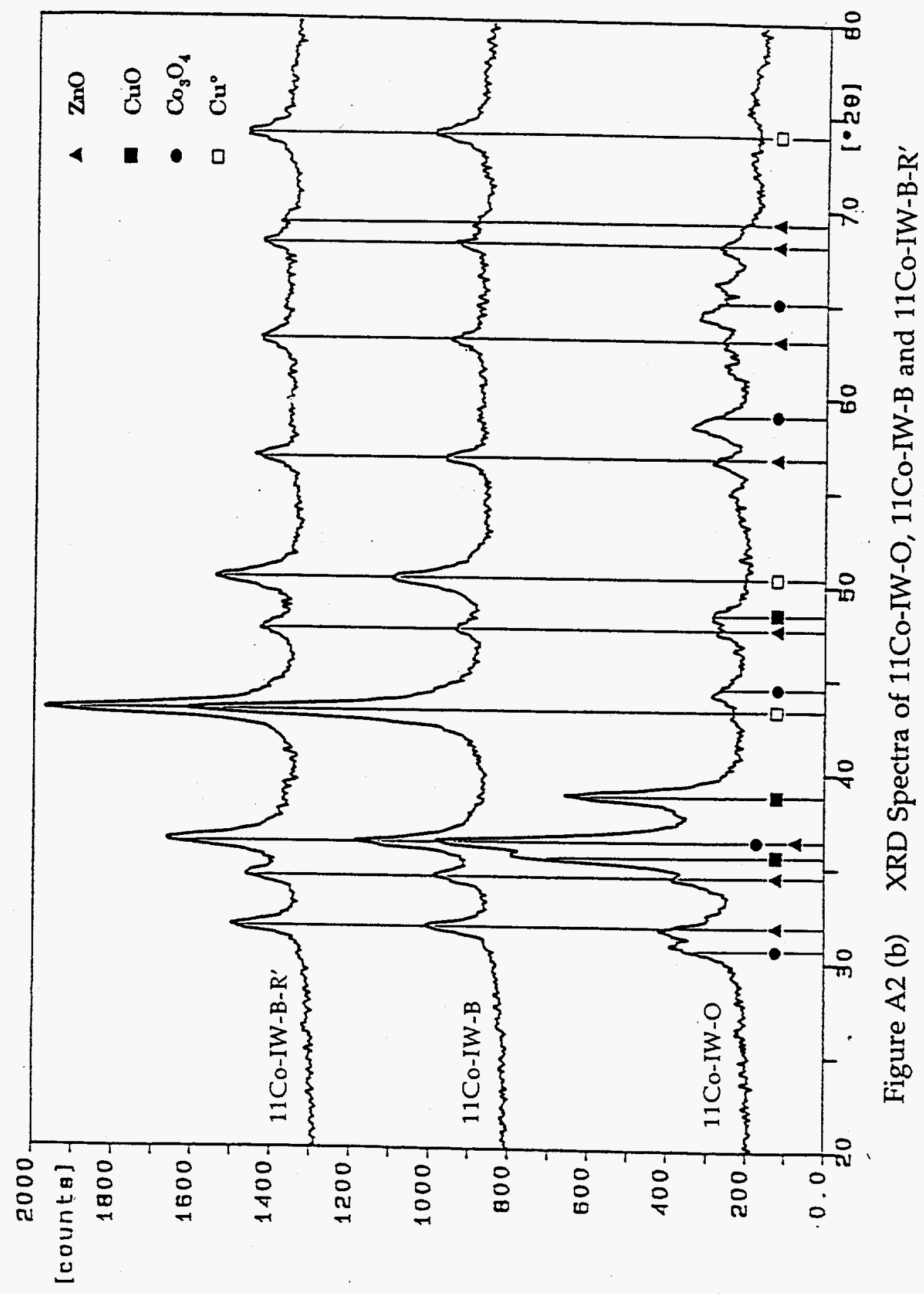




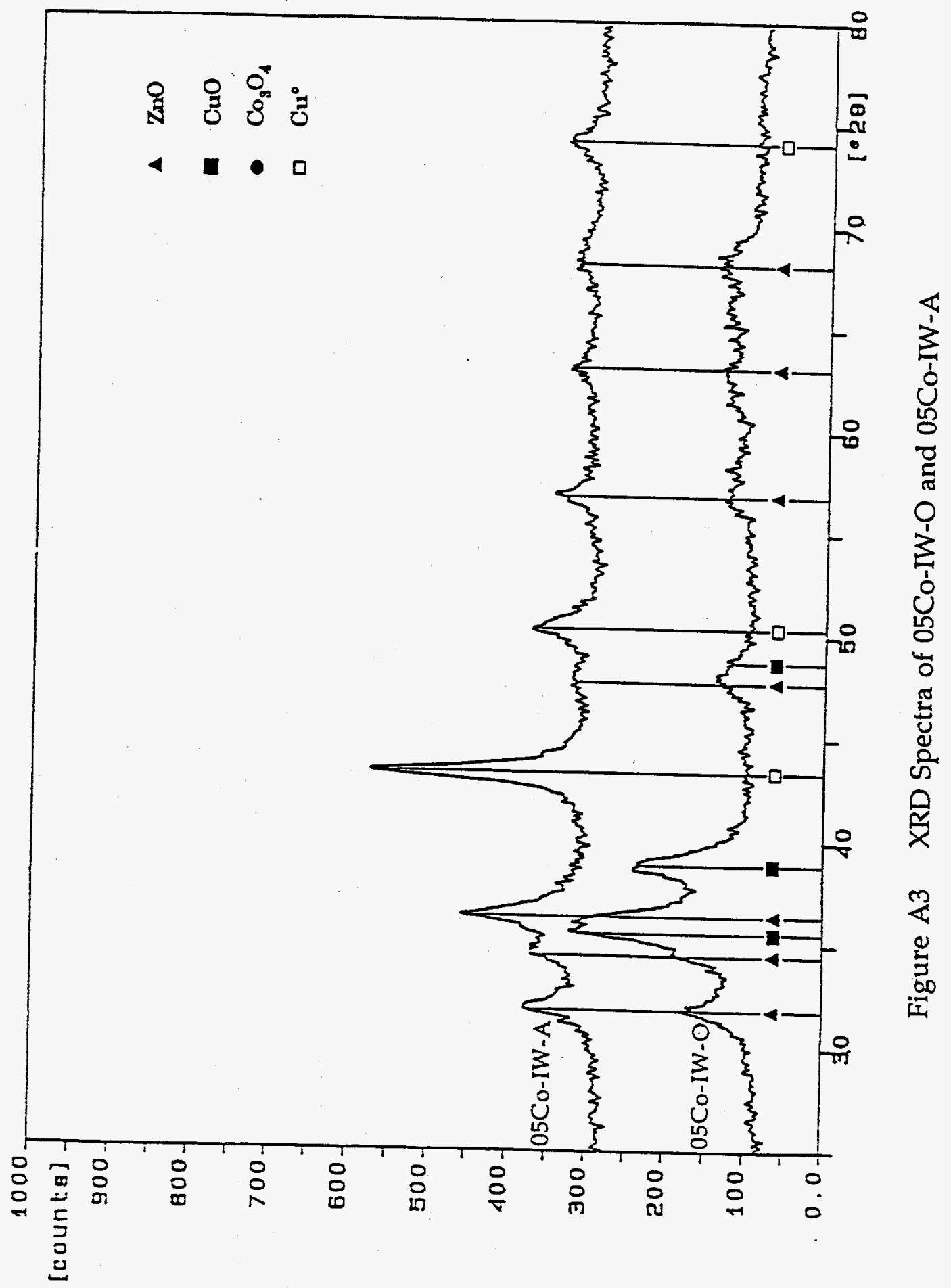




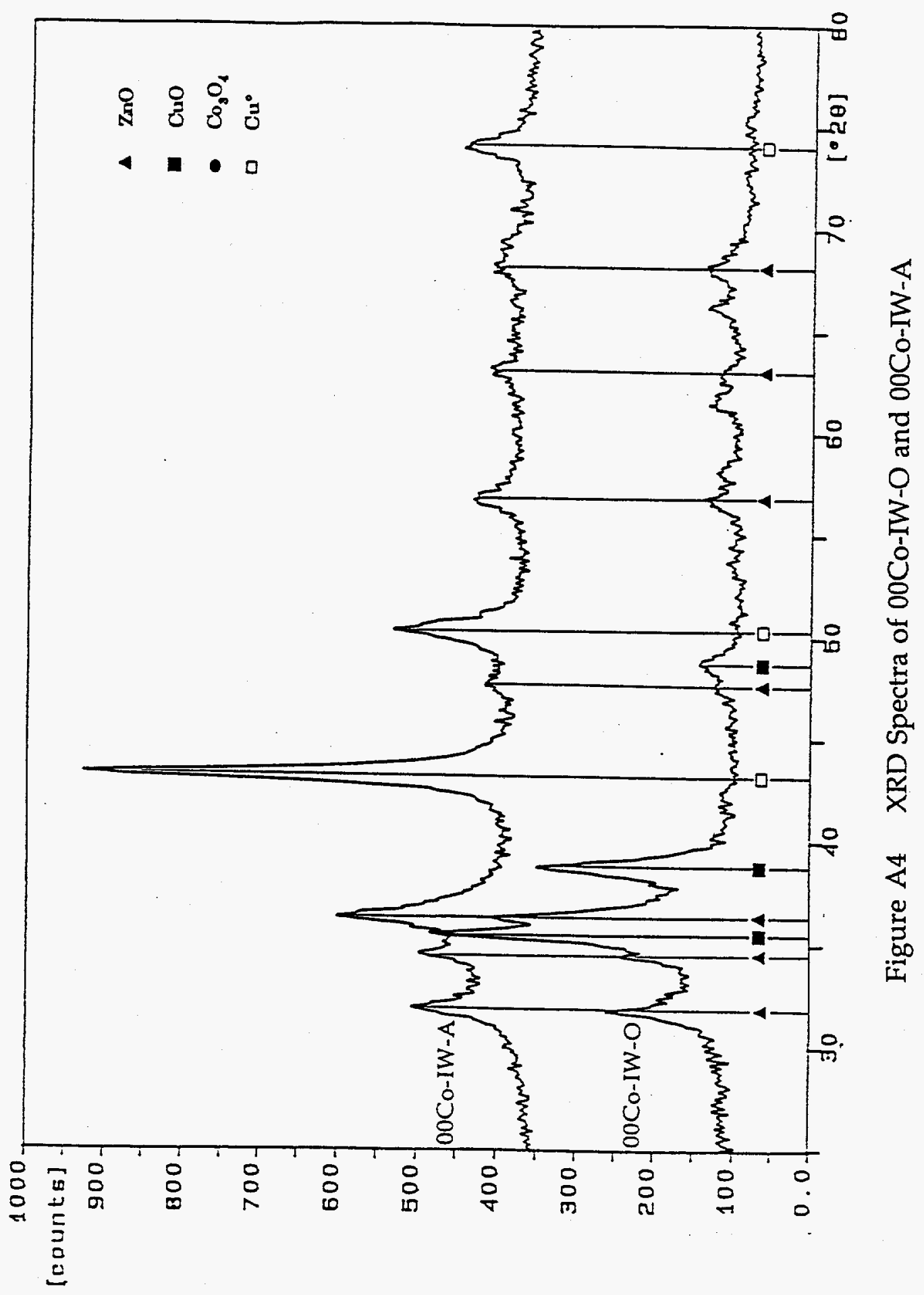




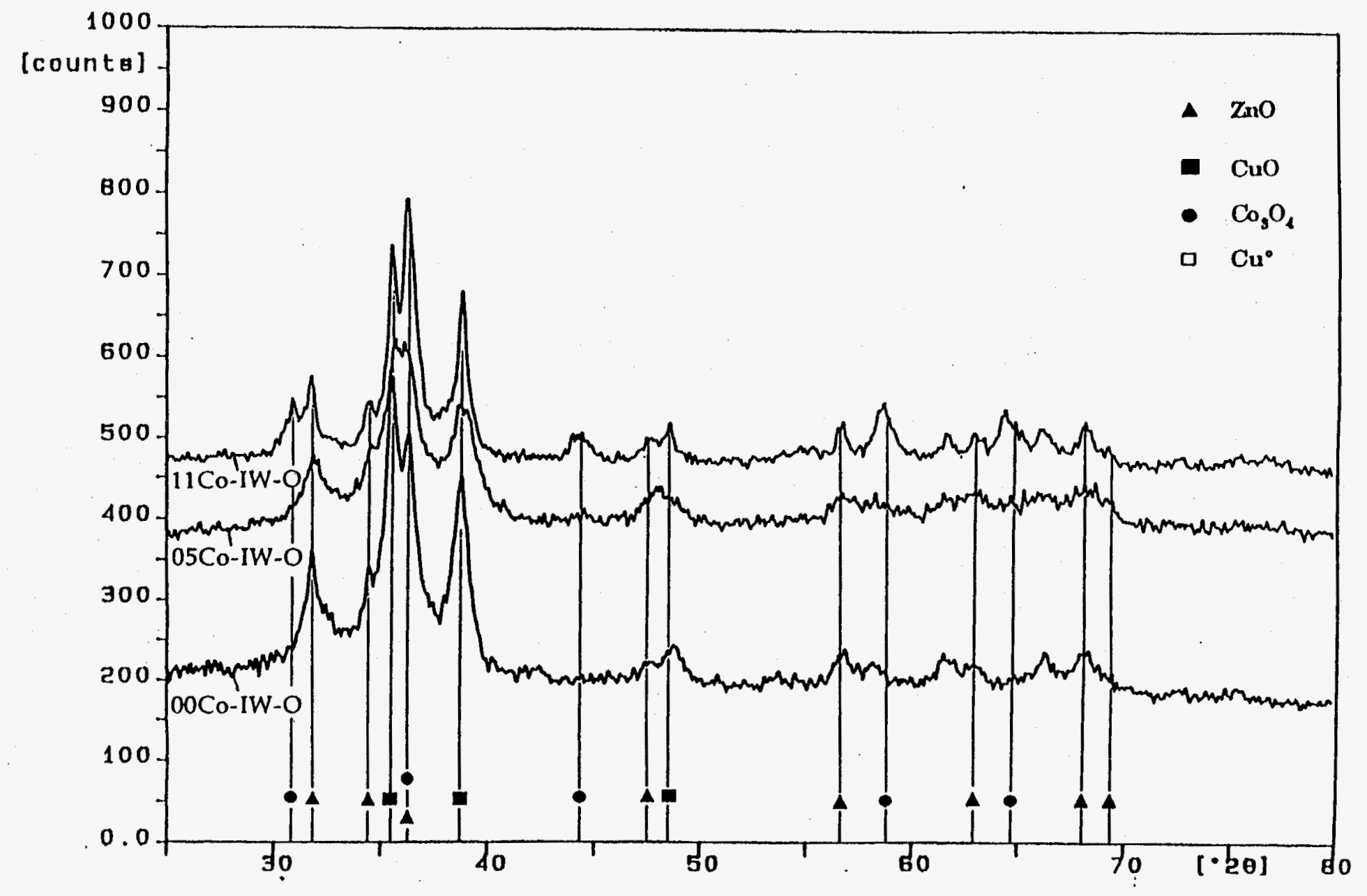

Figure A5 $(x) \quad$ XRD Spectra of 00Co-IW-O, 05Co-IW-O and 11Co-IW-O 


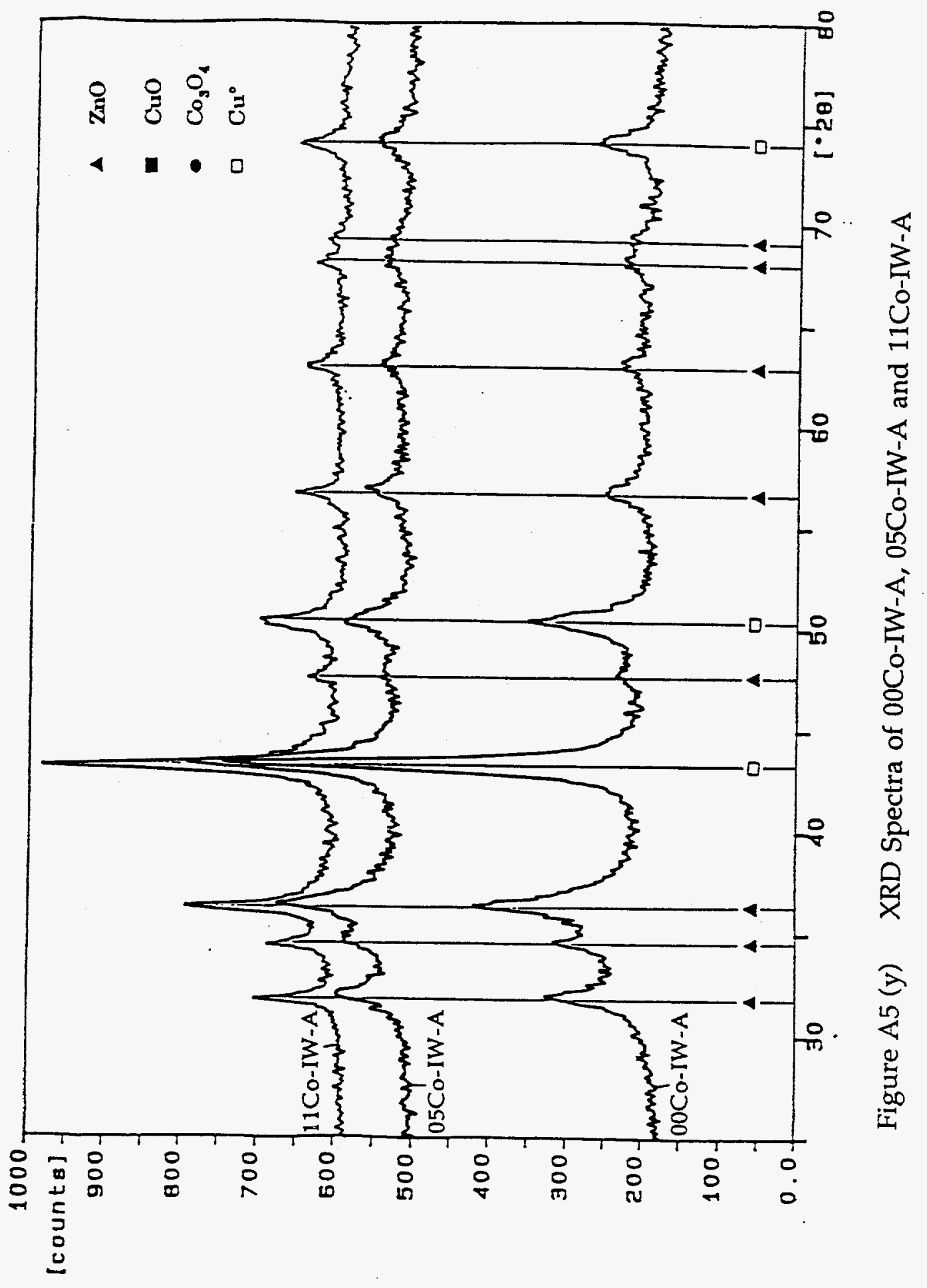




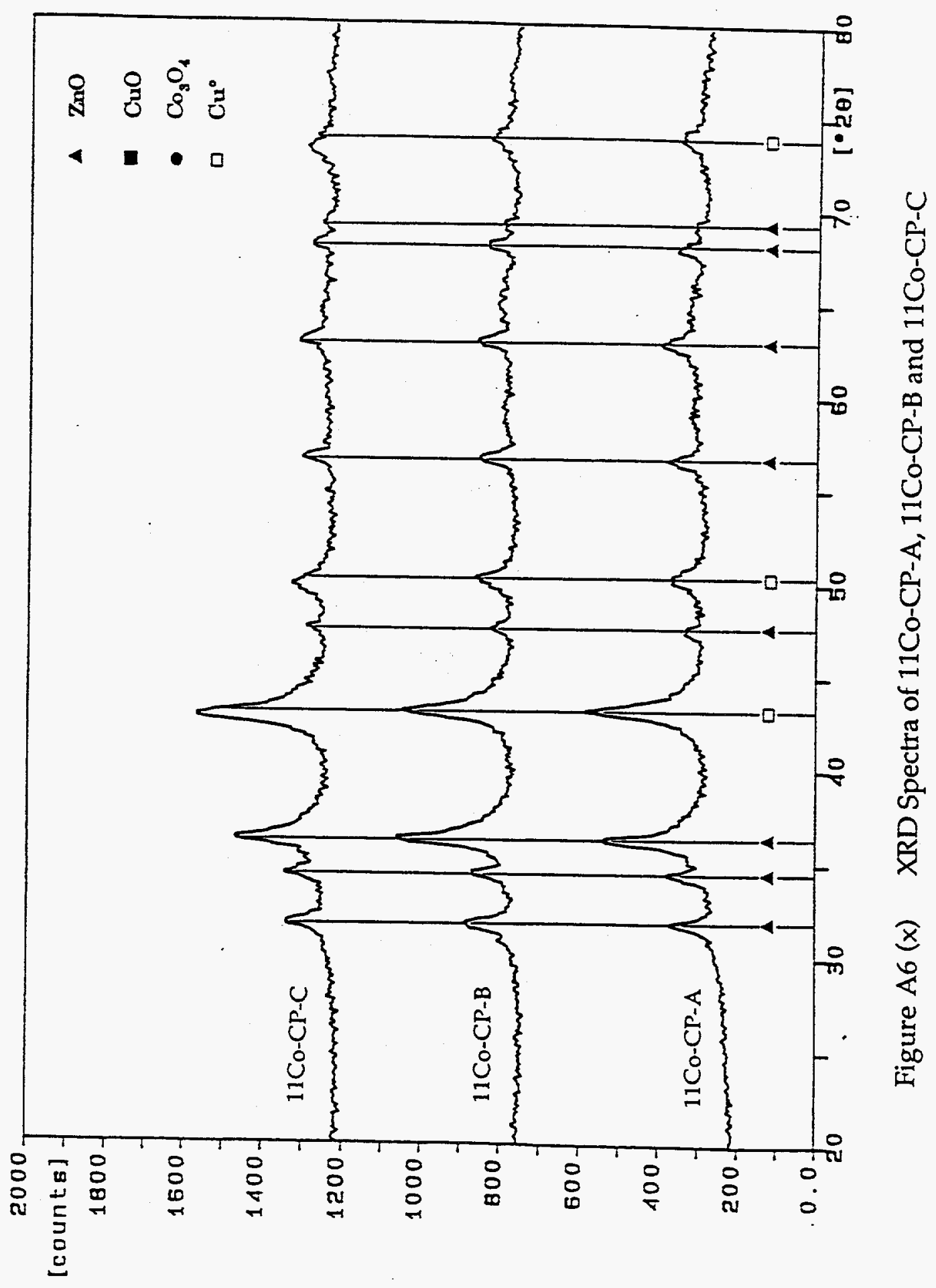




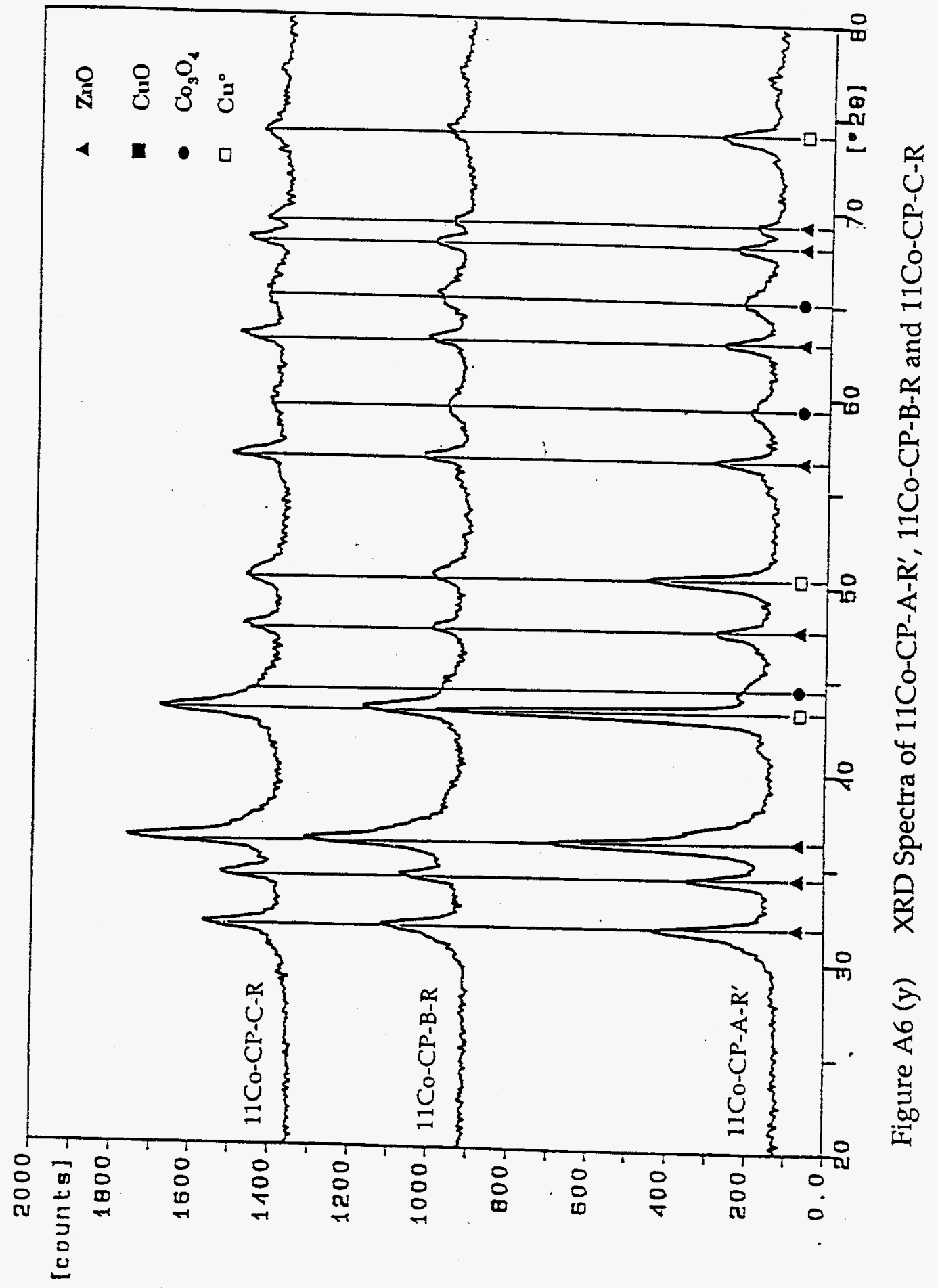




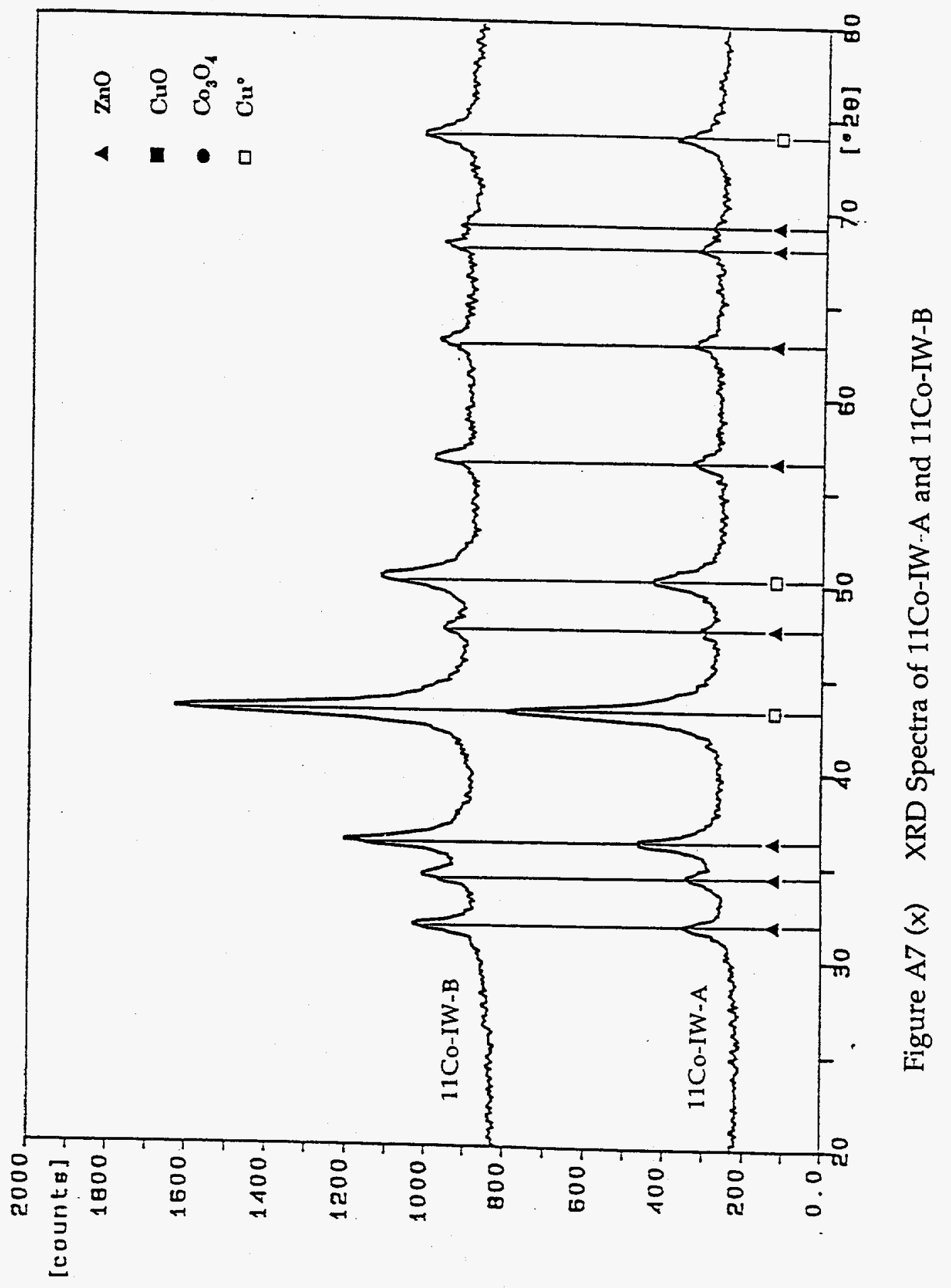




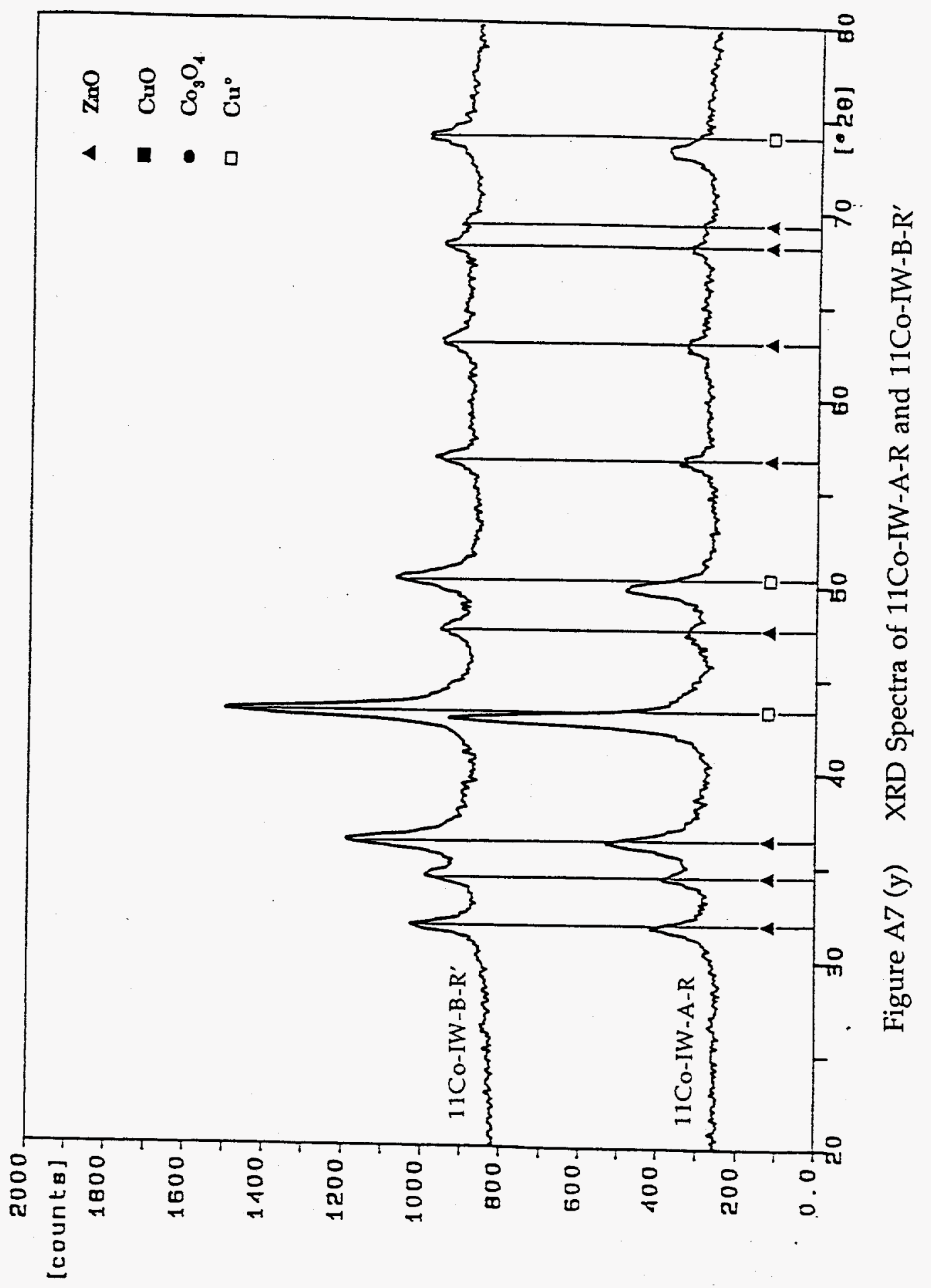





\section{APPENDIX B}




\section{APPENDIX B}

Table B1 Measured and Reference Values of Photoelectron, Auger Energy and Auger Parameter $(\alpha)$ for Copper

\begin{tabular}{|c|c|c|c|}
\hline $\begin{array}{l}\text { Catalyst } \\
\text { Sample }\end{array}$ & $\begin{array}{c}\text { Binding Energy } \\
\left(2 p_{3 / 2}, \mathrm{eV}\right)\end{array}$ & $\begin{array}{c}\text { Auger Energy } \\
\text { (LMM, eV) }\end{array}$ & $\begin{array}{c}\alpha \\
(\mathrm{eV})\end{array}$ \\
\hline 00Co-IW-O & 933.8 & 569.0 & 1851.3 \\
\hline 11 Co-IW-O & 934.1 & 569.2 & 1851.5 \\
\hline $11 \mathrm{Co}-\mathrm{CP}-\mathrm{O}$ & 934.4 & 569.7 & 1851.3 \\
\hline 00Co-IW-A & 923.4 & 567.8 & 1851.3 \\
\hline $11 \mathrm{Co}-\mathrm{IW}-\mathrm{A}$ & 932.7 & 568.0 & 1851.2 \\
\hline 11Co-CP-A & 932.9 & 568.2 & 1851.3 \\
\hline $11 \mathrm{Co}-\mathrm{CP}-\mathrm{C}$ & 932.9 & 568.2 & 1851.3 \\
\hline \multicolumn{4}{|l|}{ Copper ${ }^{b}$} \\
\hline $\mathrm{Cu}$ & 932.7 & 568.0 & 1851.3 \\
\hline $\mathrm{Cu}_{2} \mathrm{O}$ & 932.4 & 569.8 & 1849.4 \\
\hline $\mathrm{CuO}$ & 933.8 & 568.7 & 1851.7 \\
\hline
\end{tabular}

a: Refer Table 4 in section 3.2.4 for sample name.

b: The data are from reference (24). 


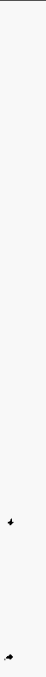


APPENDIX C 
APPENDD C

(a)

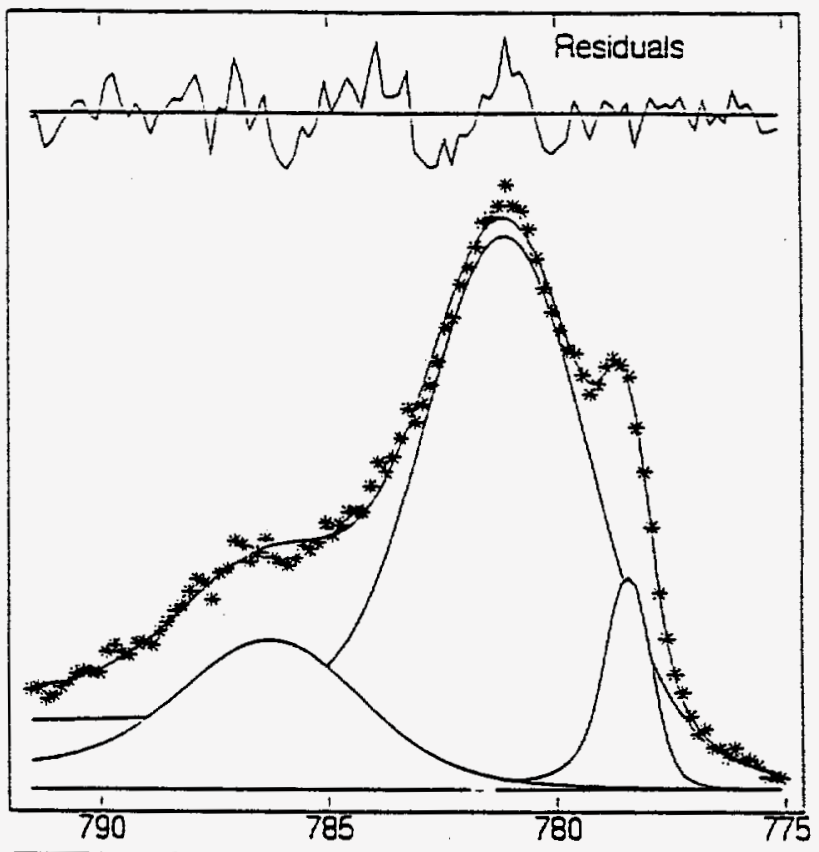

(b)

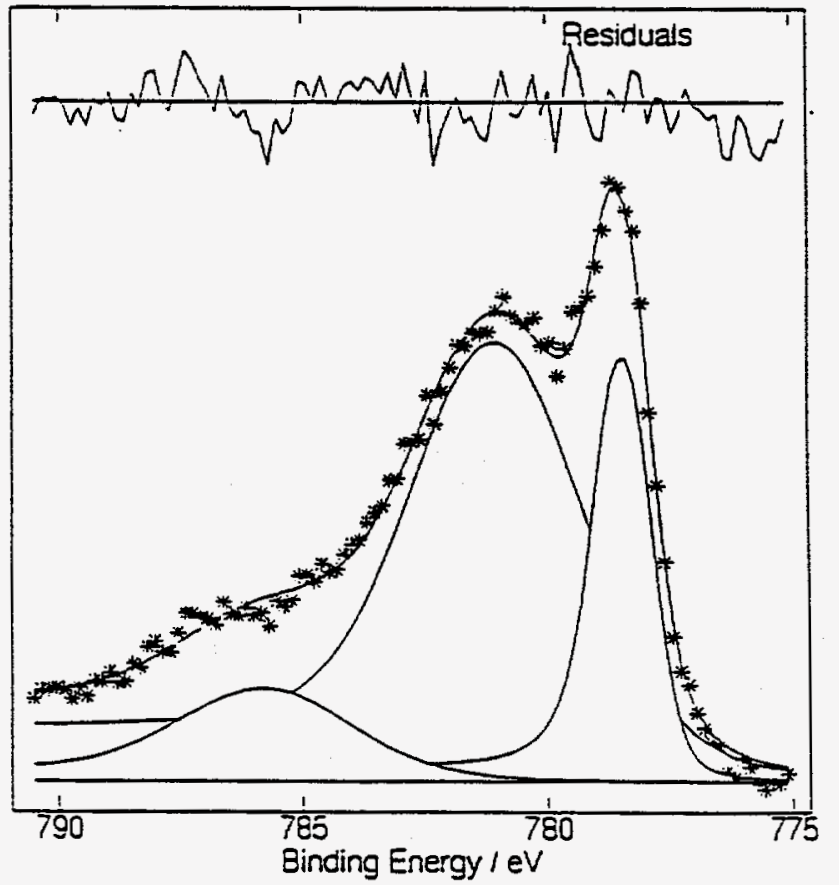

Figure C1 Curve Fitting Results of the Co $2 p$ Spectra of (a) $11 \mathrm{Co}-\mathrm{CP}-\mathrm{A}$ and (b) $11 \mathrm{Co}-\mathrm{CP}-\mathrm{C}$ 

APPENDIX D 
Table D1 Description of Condictions and Procedures of the TPR and Related Testing Experiments with $\mathrm{H}_{2} \mathrm{O}$ by MS

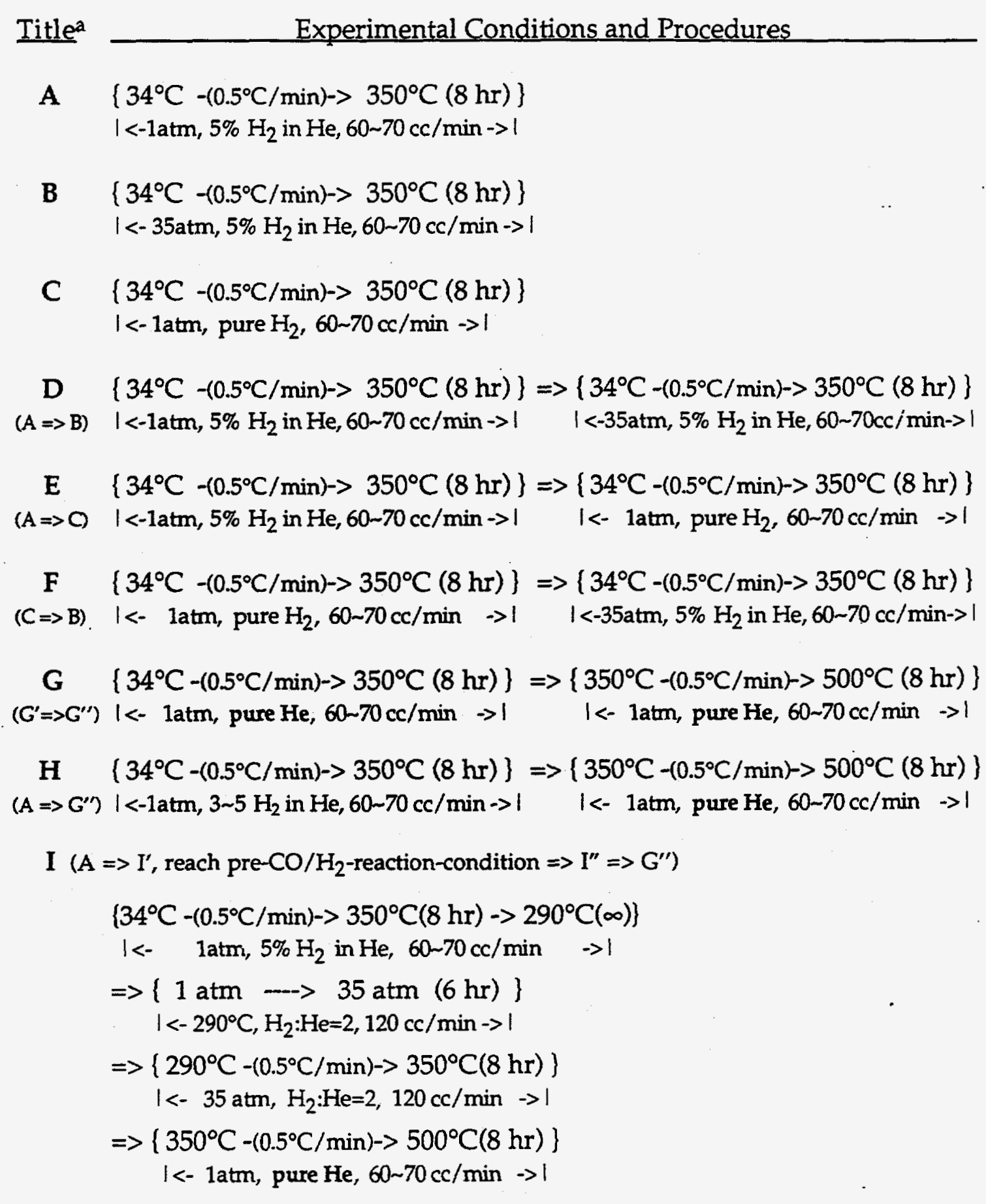

a: A F are equivalent to the treatments described in Table 2. 

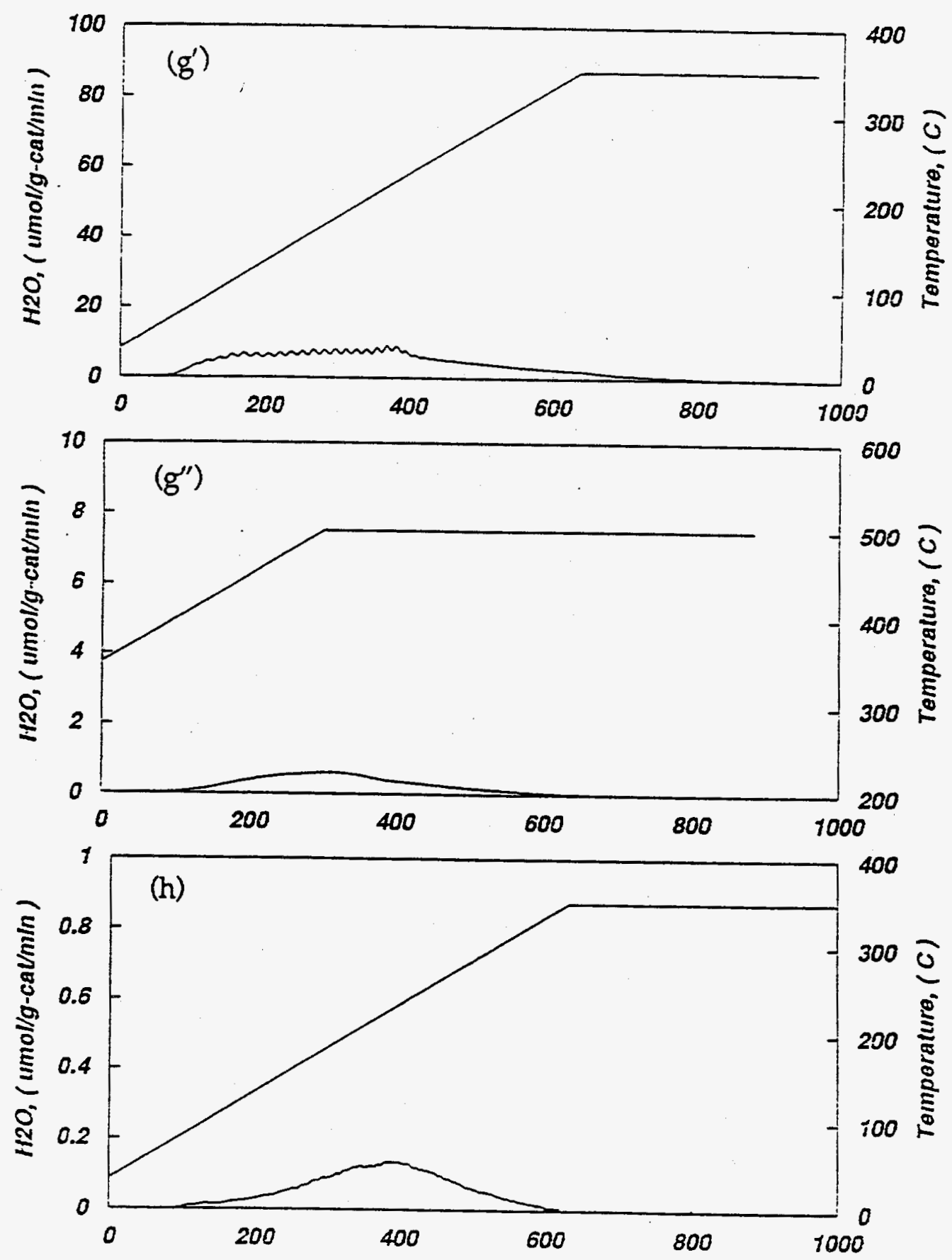

Time, ( $\min )$

Figure D1 $\left(g^{\prime}, g^{\prime \prime}, h\right)$ Blank TPR Profiles of 11Co-CP by Condition $\left(g^{\prime}\right) \mathrm{G}$, $\left(g^{\prime \prime}\right) G^{\prime \prime}$ and $(h) H$ as Described in Table 11 \& D 

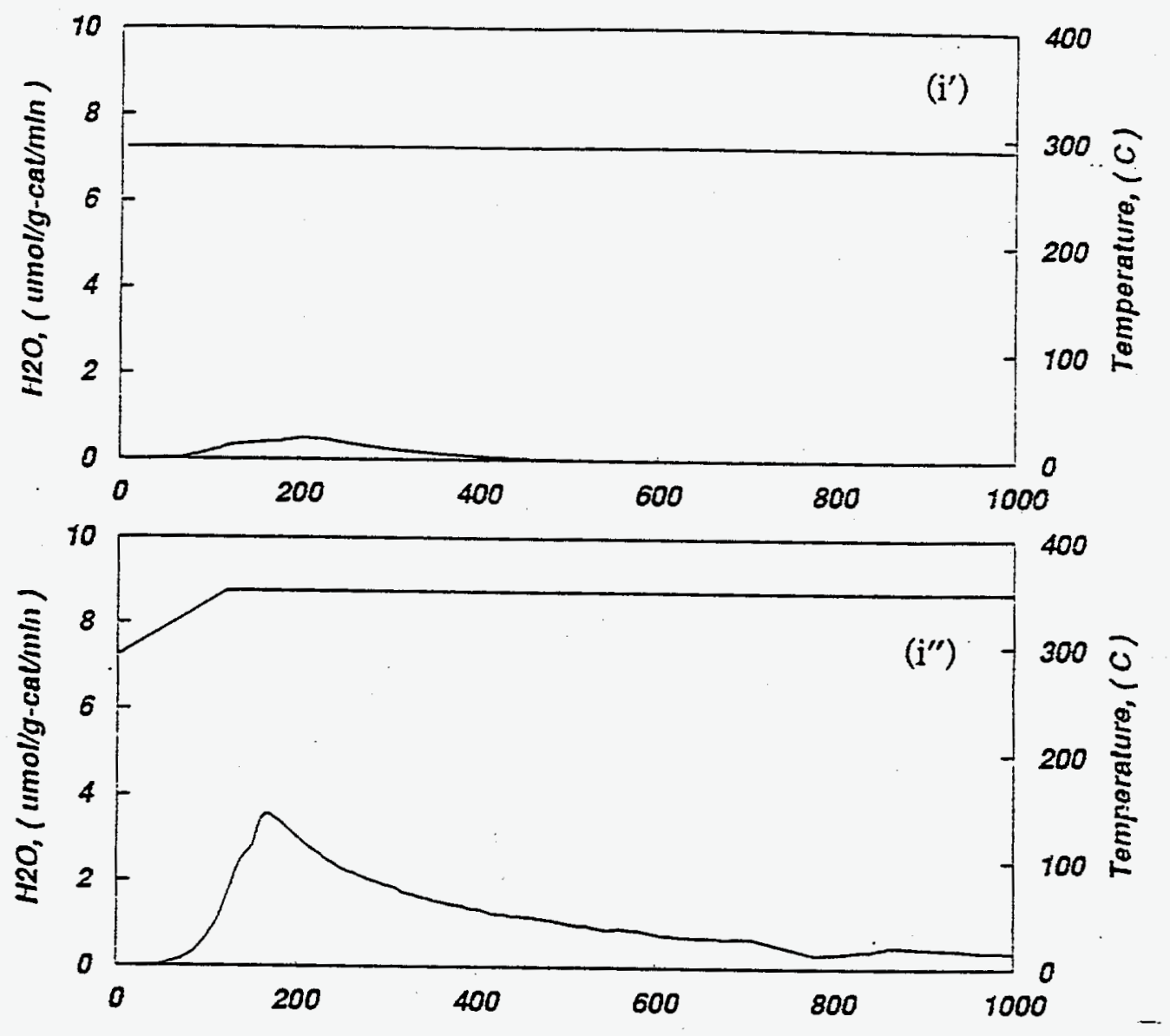

Time, ( $\min$ )

Figure D1 ( $\left.i^{\prime}, i^{\prime \prime}\right)$ TPR Profiles of 11Co-CP Reduced at Condition (i') $I^{\prime}$, and $\left(i^{\prime \prime}\right) I^{\prime \prime}$ as Described in Table 11 \& D 

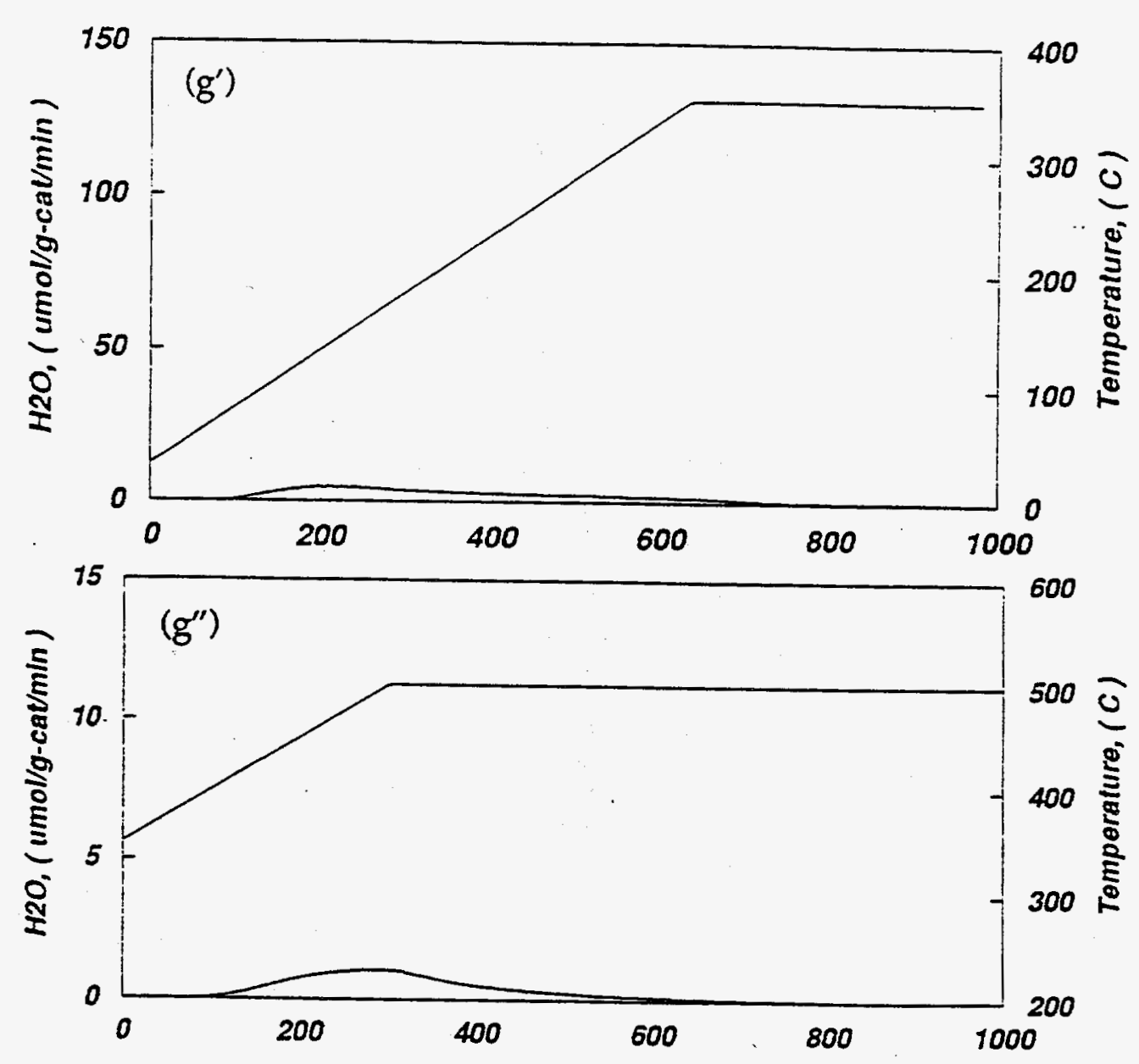

Time, ( $\min )$

Figure D2 Blank TPR Profiles of 11Co-IW by Condition $\left(g^{\prime}\right) G^{\prime}$ and $\left(g^{\prime \prime}\right) G^{\prime \prime}$ as Described in Table 11 \& D 
APPENDIX E 


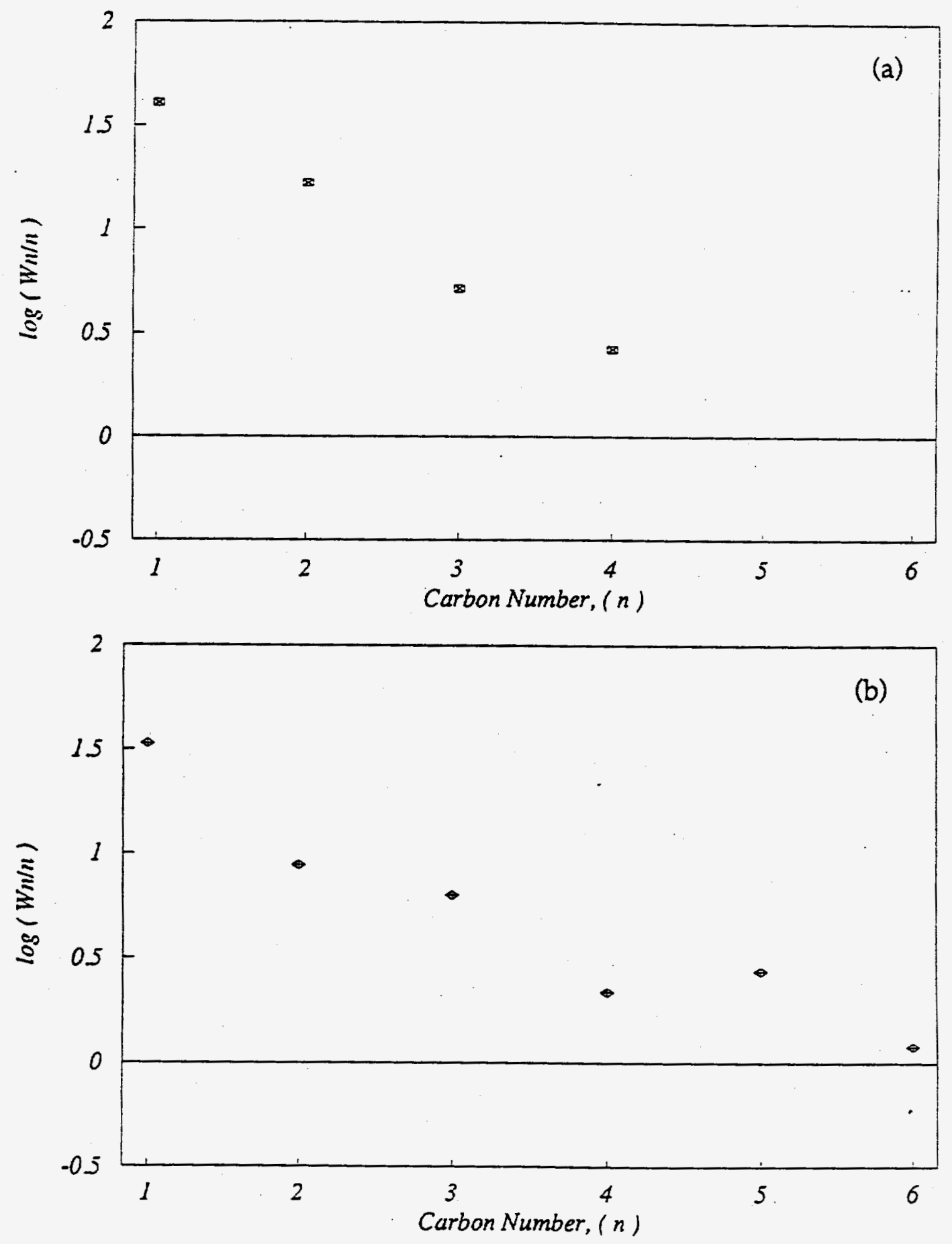

Figure E1 ASF Plots for (a) $C_{1}-C_{6}$ Alcohols and (b) $C_{1}-C_{6}$ Hydrocarboris Produced over 11Co-CP Received Reduction Treatment A 

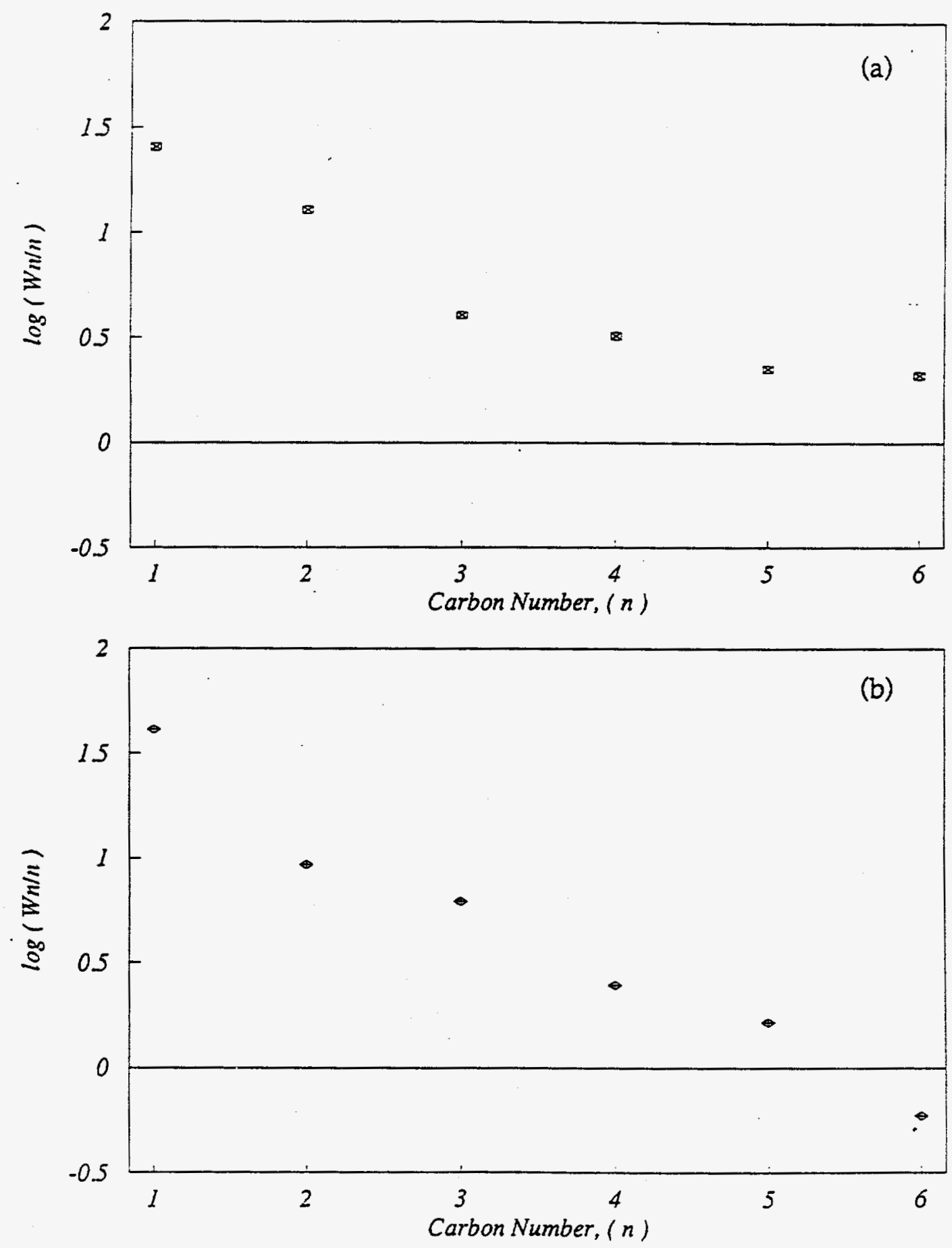

Figure E2 ASF Plots for (a) $C_{1} \sim C_{6}$ Alcohols and (b) $C_{1} \sim C_{6}$ Hydrocarbons Produced over 11Co-CP Received Reduction Treatment $\mathrm{B}$ 

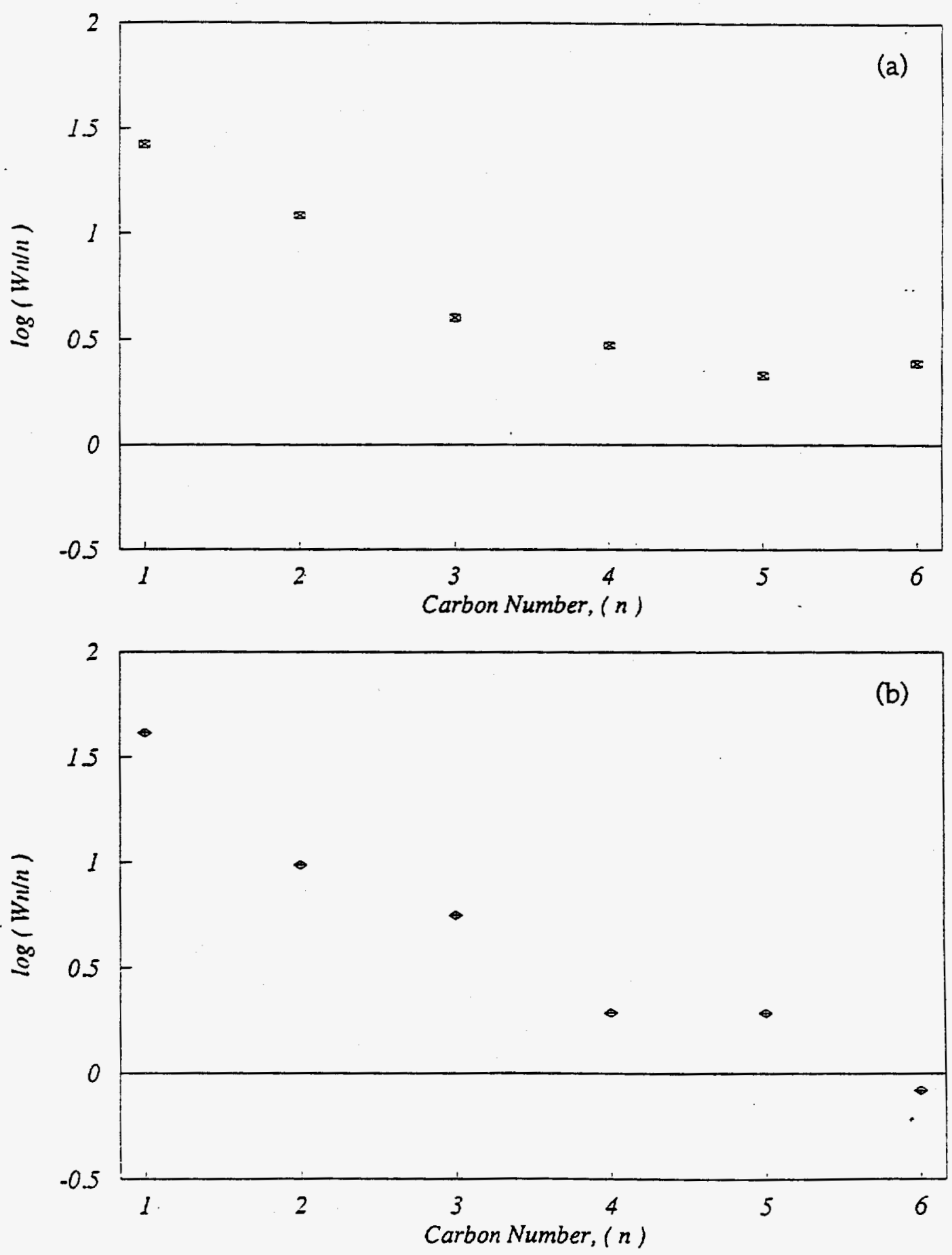

Figure E3 ASF Plots for (a) $C_{1}-C_{6}$ Alcohols and (b) $C_{1} \sim C_{6}$ Hydrocarbons Produced over 11Co-CP Received Reduction Treatment C 

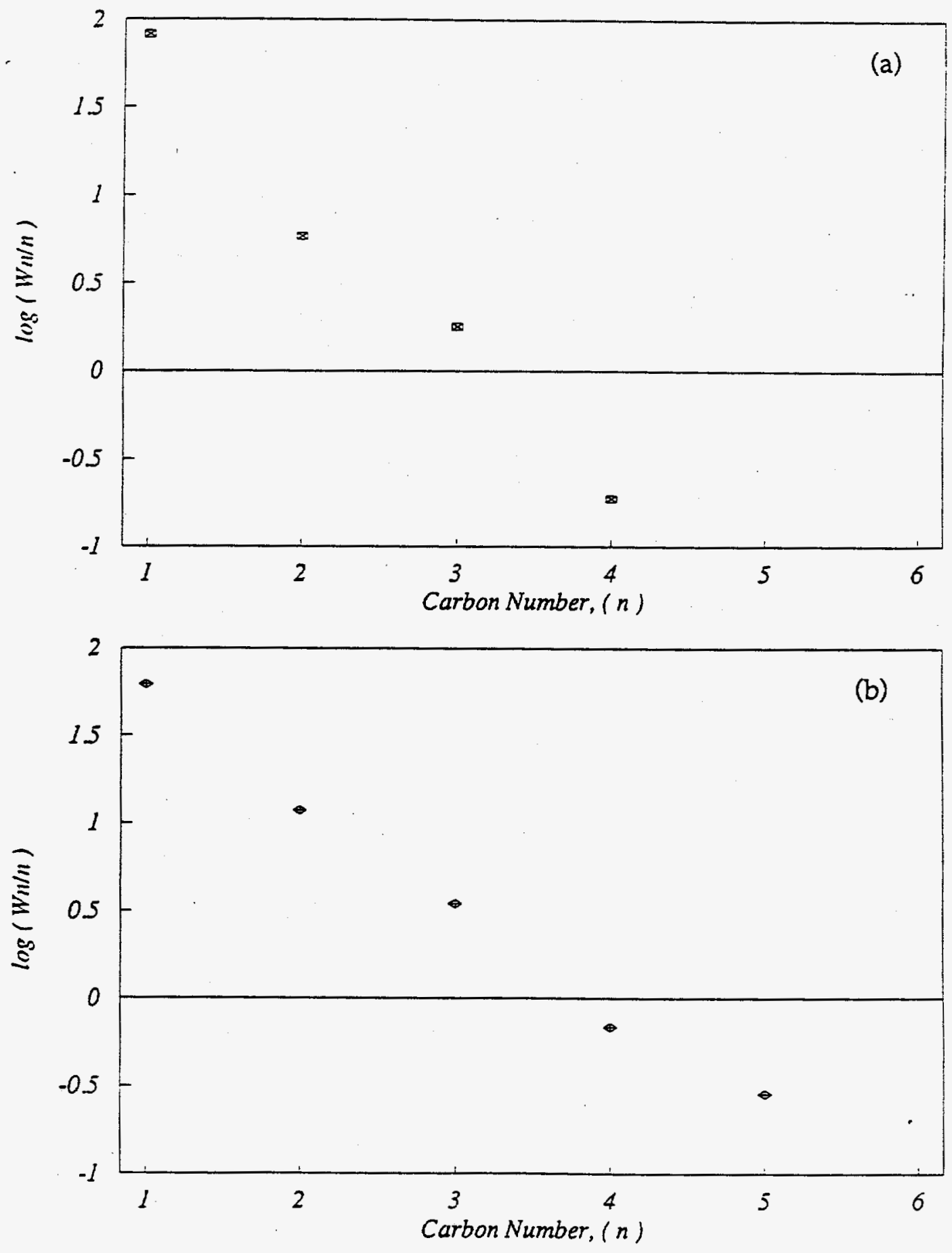

Figure E4 ASF Plots for (a) $C_{1} \sim C_{6}$ Alcohols and (b) $C_{1} \sim C_{6}$ Hydrocarbons Produced over 11Co-IW Received Reduction Treatment A 

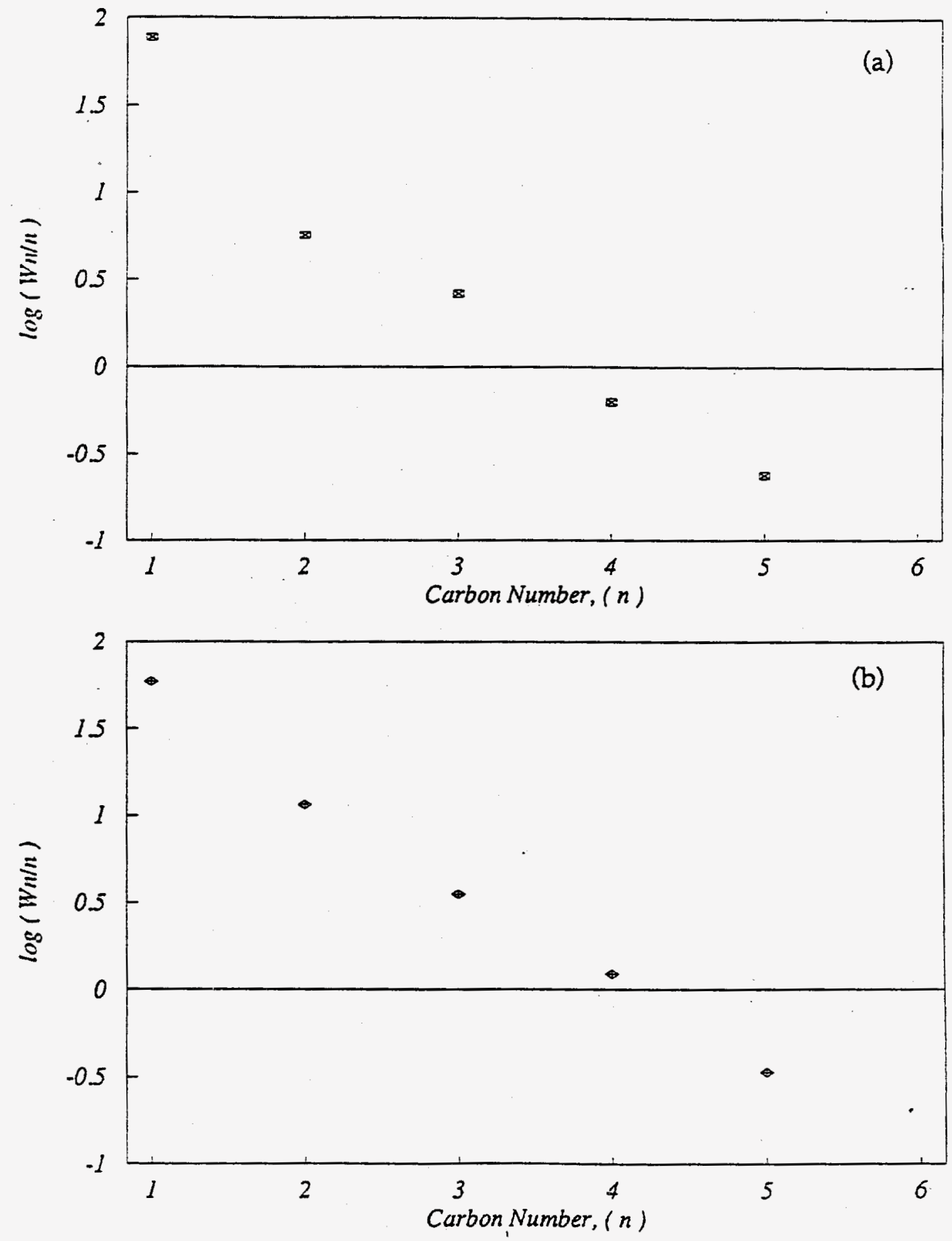

Figure E5 ASF Plots for (a) $C_{1} \sim C_{6}$ Alcohols and (b) $C_{1} \sim C_{6}$ Hydrocarbons Produced over 11Co-IW Received Reduction Treatment $B$ 

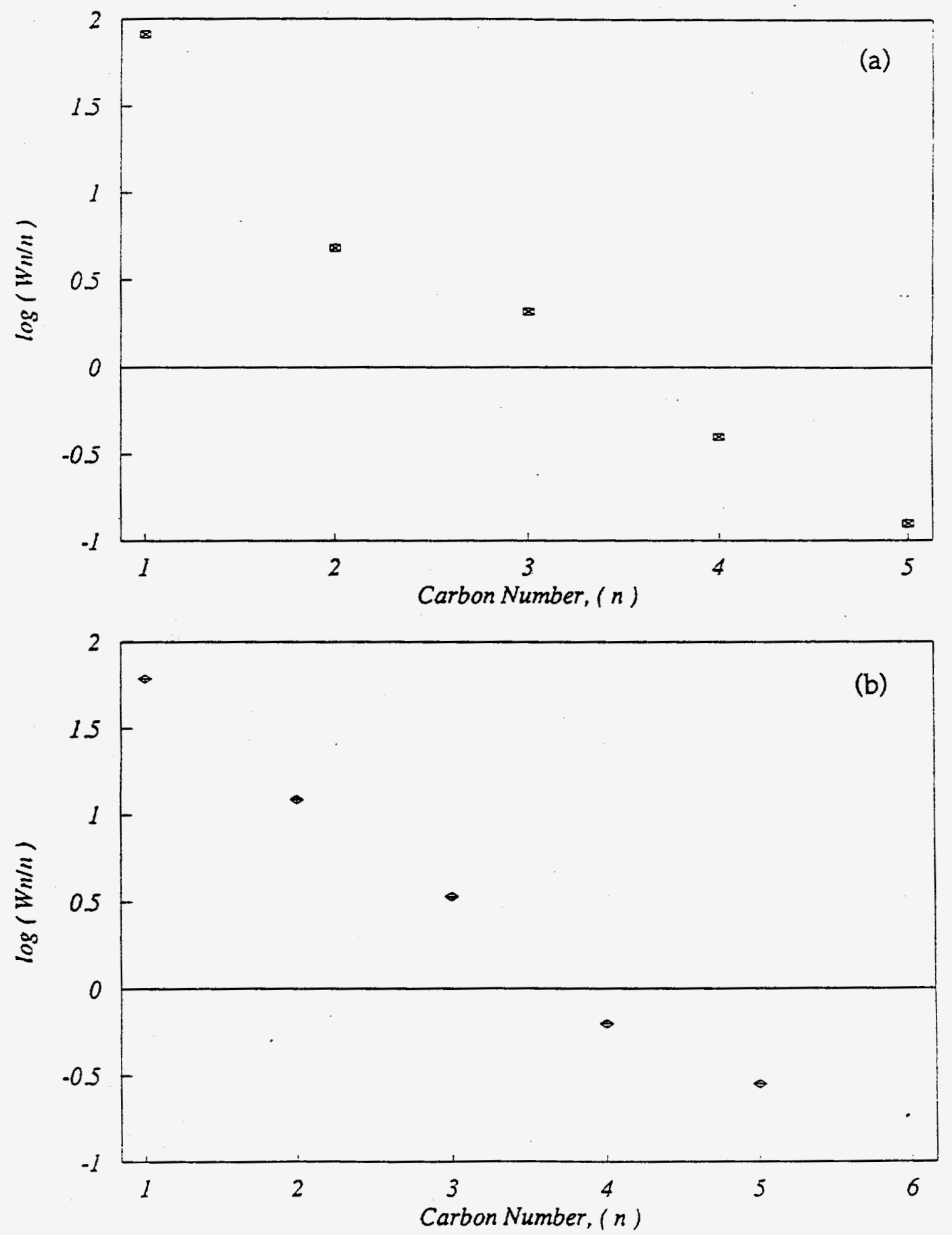

Figure $E 6$ ASF Plots for (a) $C_{1}-C_{6}$ Alcohols and (b) $C_{1}-C_{6}$ Hydrocarbons Produced over 11Co-IW Received Reduction Treatment C 


\author{
•
}


APPENDIX F 

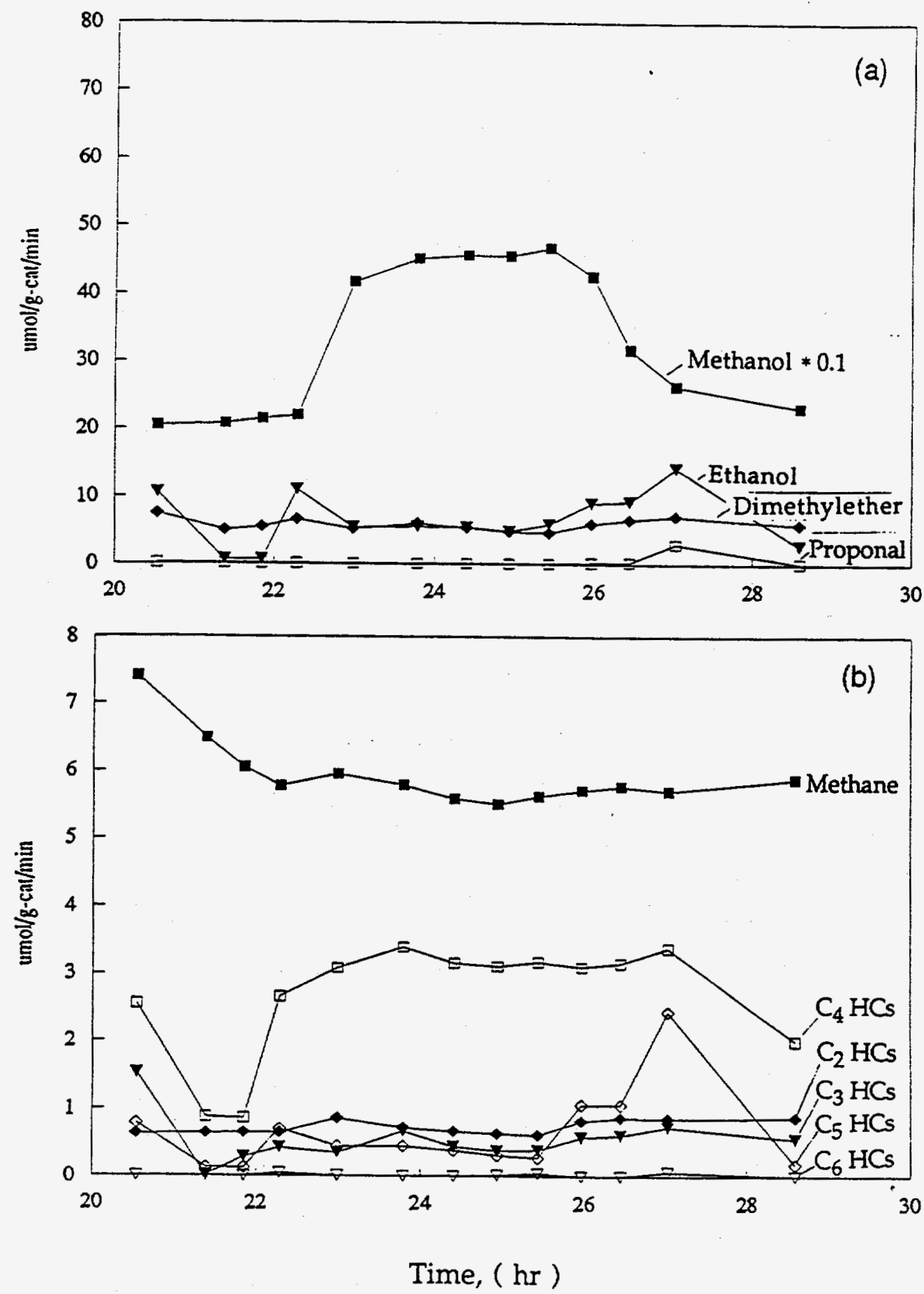

Figure F1 Formation Rates of (a) Alcohols and (b) Hydrocarbons without and with $\mathrm{CH}_{3} \mathrm{NO}_{2}$ Addition to $\mathrm{CO} / \mathrm{H}_{2}$ over $00 \mathrm{Co}-\mathrm{IW}-\mathrm{A}$ 

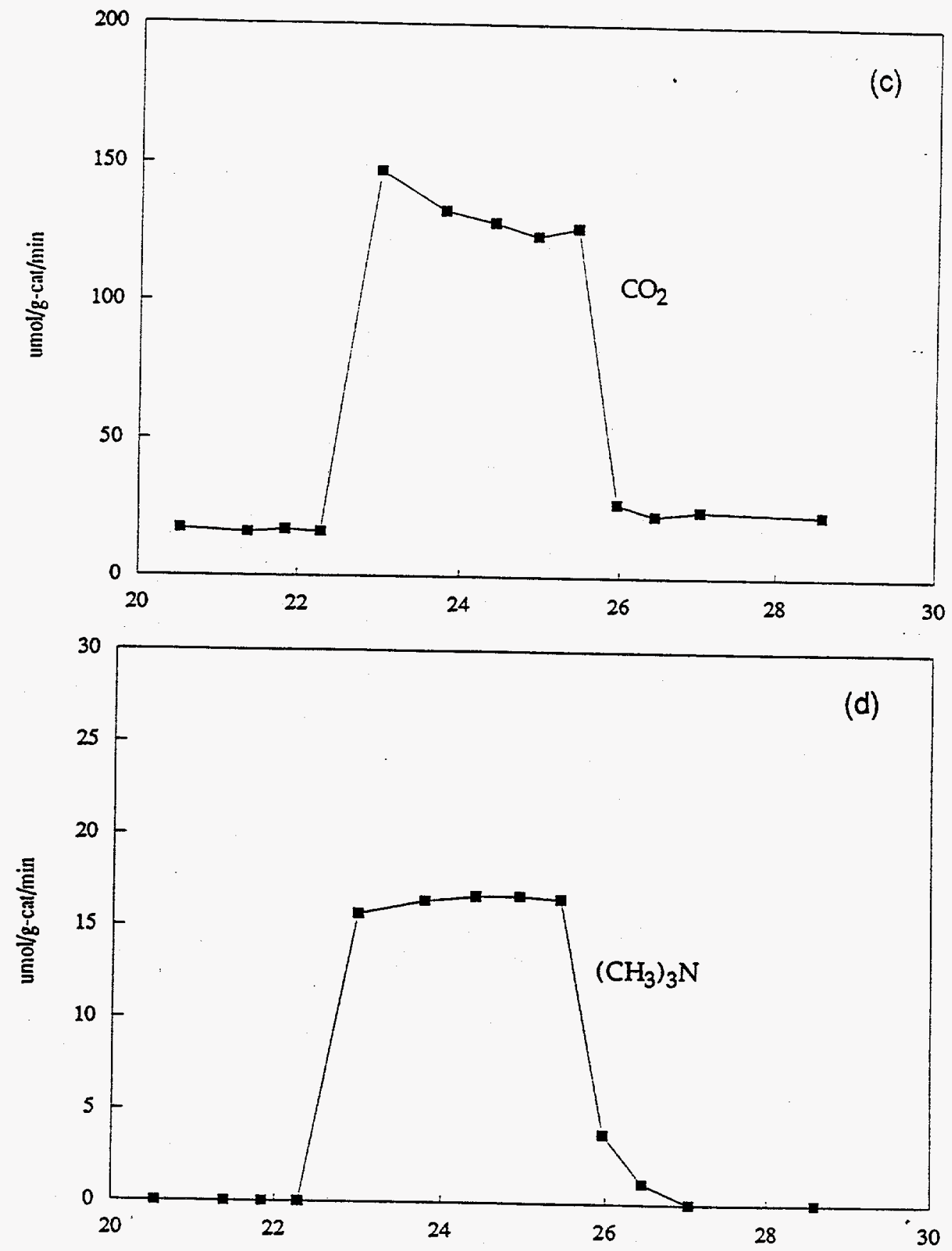

Time, ( $\mathrm{hr}$ )

Figure F1 (Continued) Formation Rates of (c) $\mathrm{CO}_{2}$ and (d) $\left(\mathrm{CH}_{3}\right)_{3} \mathrm{~N}$ without and with $\mathrm{CH}_{3} \mathrm{NO}_{2}$ Addition to $\mathrm{CO} / \mathrm{H}_{2}$ over $00 \mathrm{Co}-\mathrm{IW}-\mathrm{A}$ 

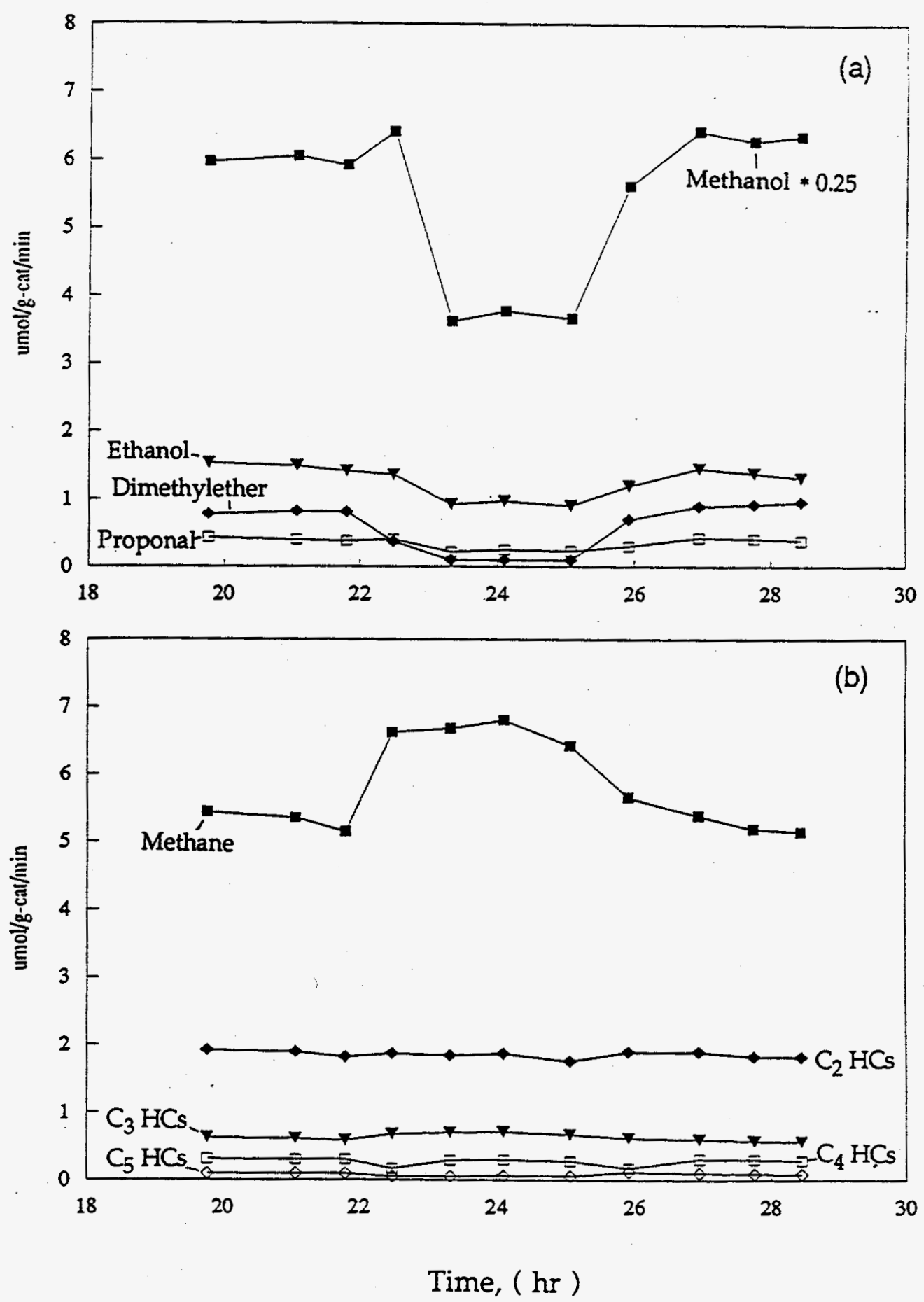

Figure F2 Formation Rates of (a) Alcohols and (b) Hydrocarbons without and with $\mathrm{CH}_{3} \mathrm{NO}_{2}$ Addition to $\mathrm{CO} / \mathrm{H}_{2}$ over $05 \mathrm{Co}-\mathrm{IW}-\mathrm{A}$ 

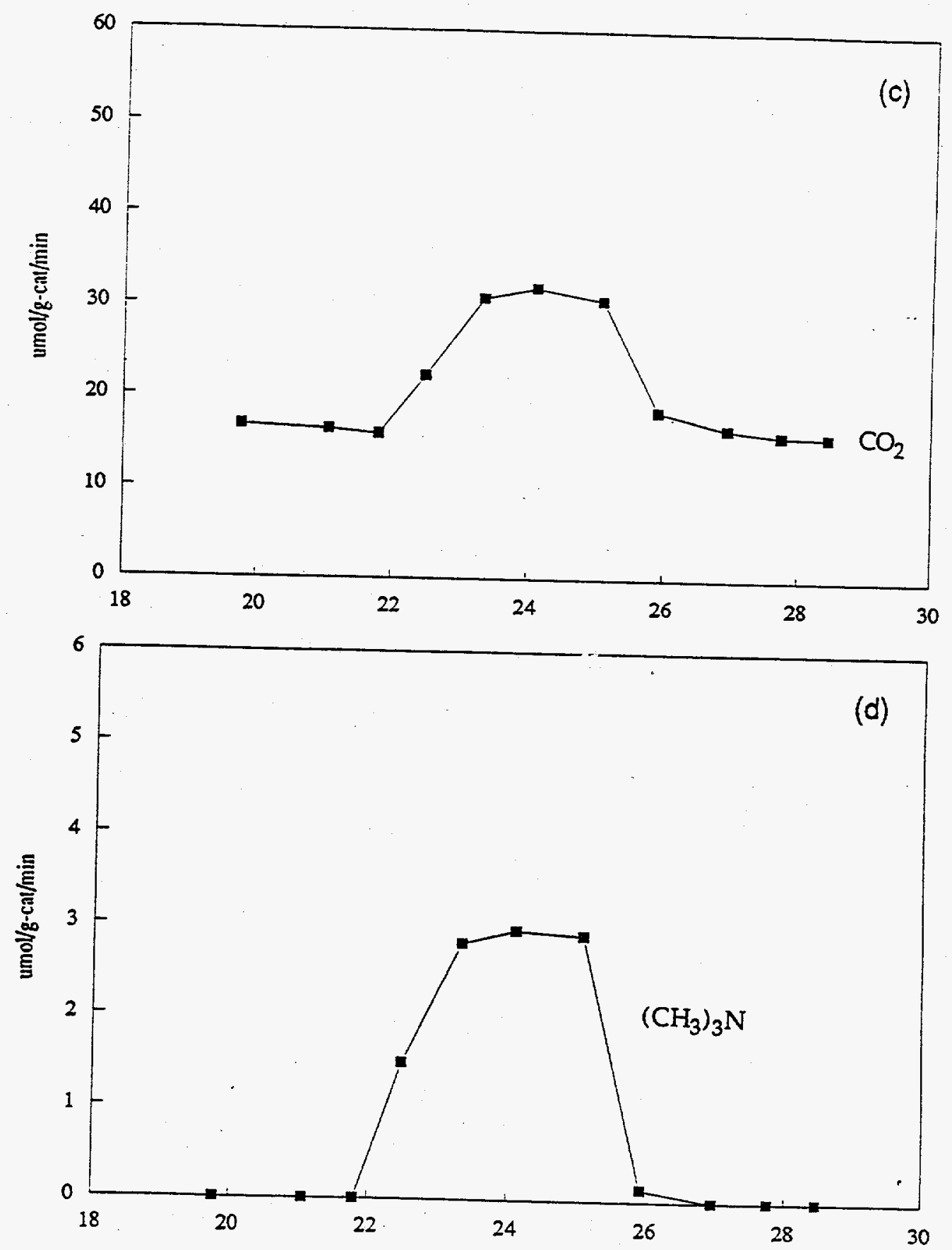

Time, ( hr )

Figure F2 (Continued) Formation Rates of (c) $\mathrm{CO}_{2}$ and (d) $\left(\mathrm{CH}_{3}\right)_{3} \mathrm{~N}$ without and with $\mathrm{CH}_{3} \mathrm{NO}_{2}$ Addition to $\mathrm{CO} / \mathrm{H}_{2}$ over $05 \mathrm{Co}-\mathrm{IW}-\mathrm{A}$ 

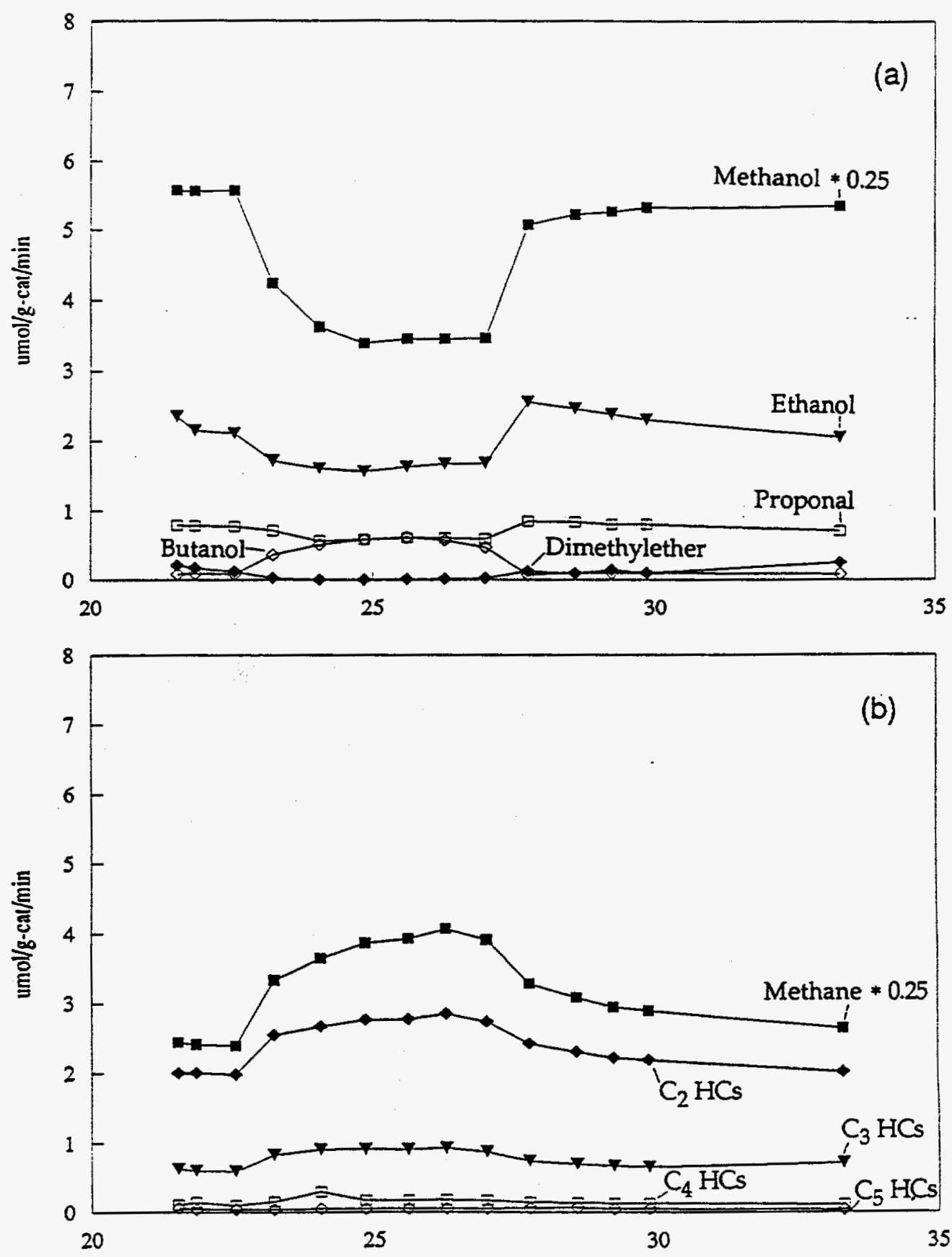

Time, ( hr )

Figure F3 Formation Rates of (a) Alcohols and (b) Hydrocarbons without and with $\mathrm{CH}_{3} \mathrm{NO}_{2}$ Addition to $\mathrm{CO} / \mathrm{H}_{2}$ over $11 \mathrm{Co}-\mathrm{IW}-\mathrm{A}$ 

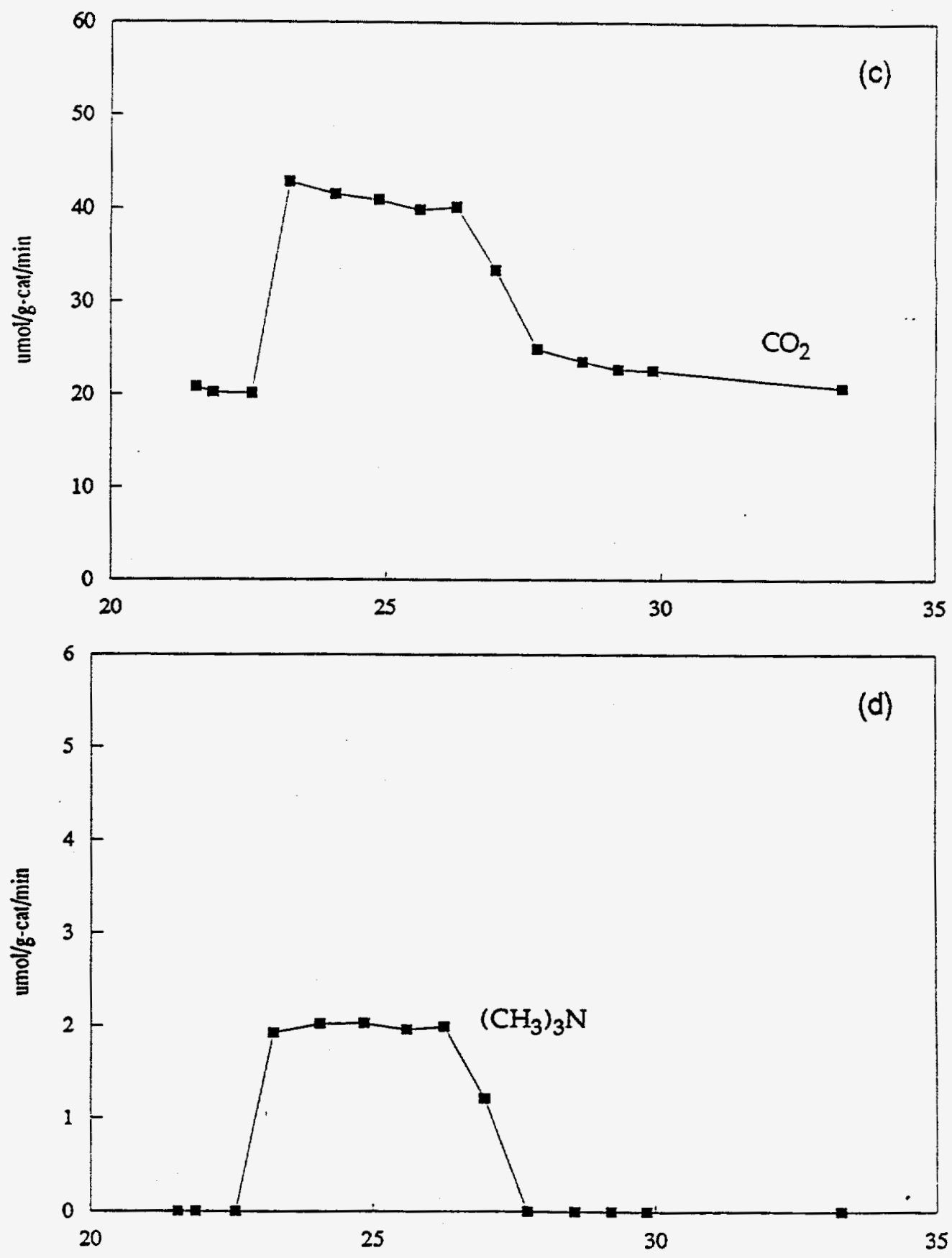

Time, ( $\mathrm{hr}$ )

Figure F3 (Continued) Formation Rates of (c) $\mathrm{CO}_{2}$ and (d) $\left(\mathrm{CH}_{3}\right)_{3} \mathrm{~N}$ without and with $\mathrm{CH}_{3} \mathrm{NO}_{2}$ Addition to $\mathrm{CO} / \mathrm{H}_{2}$ over $11 \mathrm{Co}-\mathrm{IW}-\mathrm{A}$ 

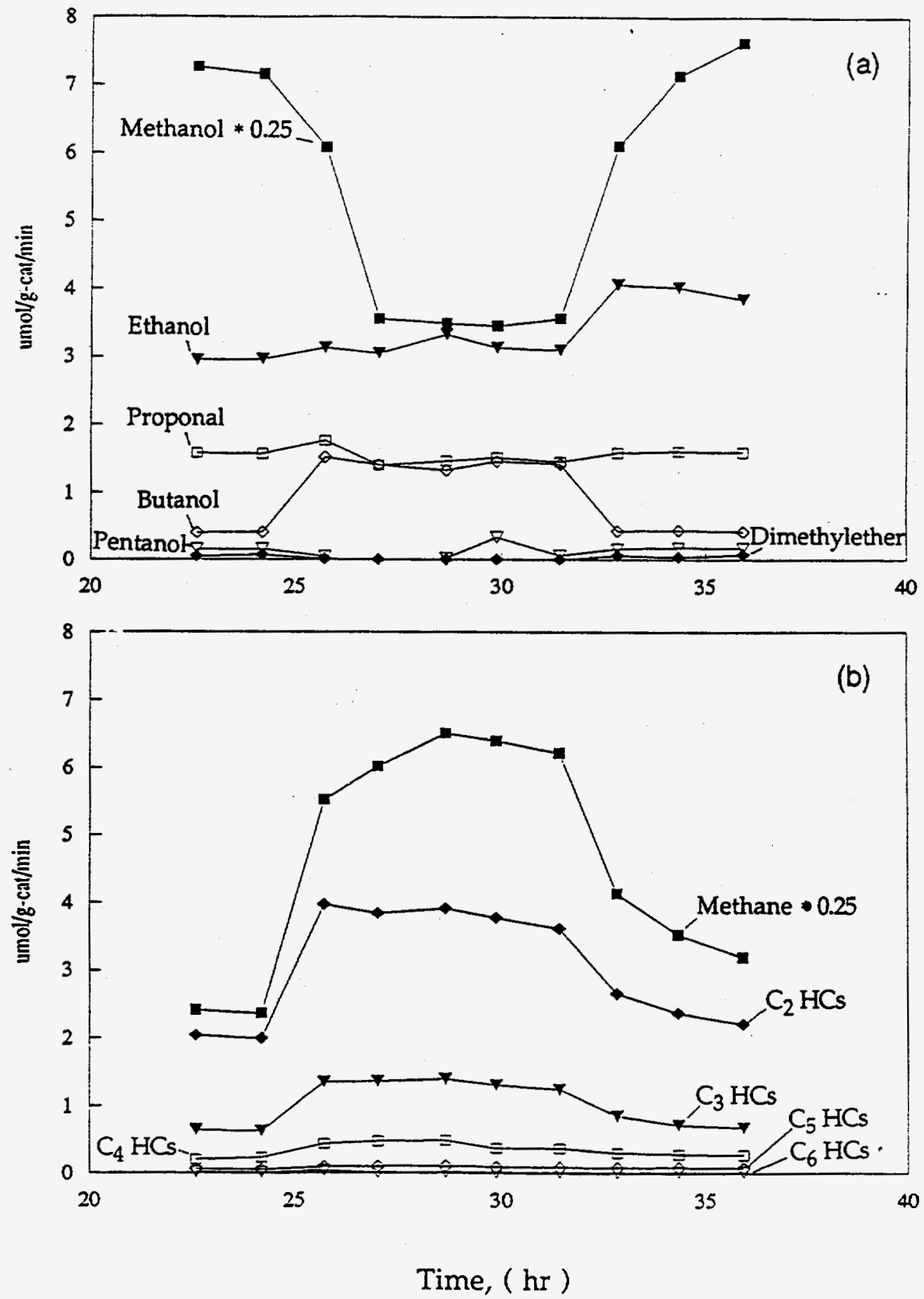

Figure F4 Formation Rates of (a) Alcohols and (b) Hydrocarbons without and with $\mathrm{CH}_{3} \mathrm{NO}_{2}$ Addition to $\mathrm{CO} / \mathrm{H}_{2}$ over $11 \mathrm{Co}-\mathrm{IW}-\mathrm{B}$ 

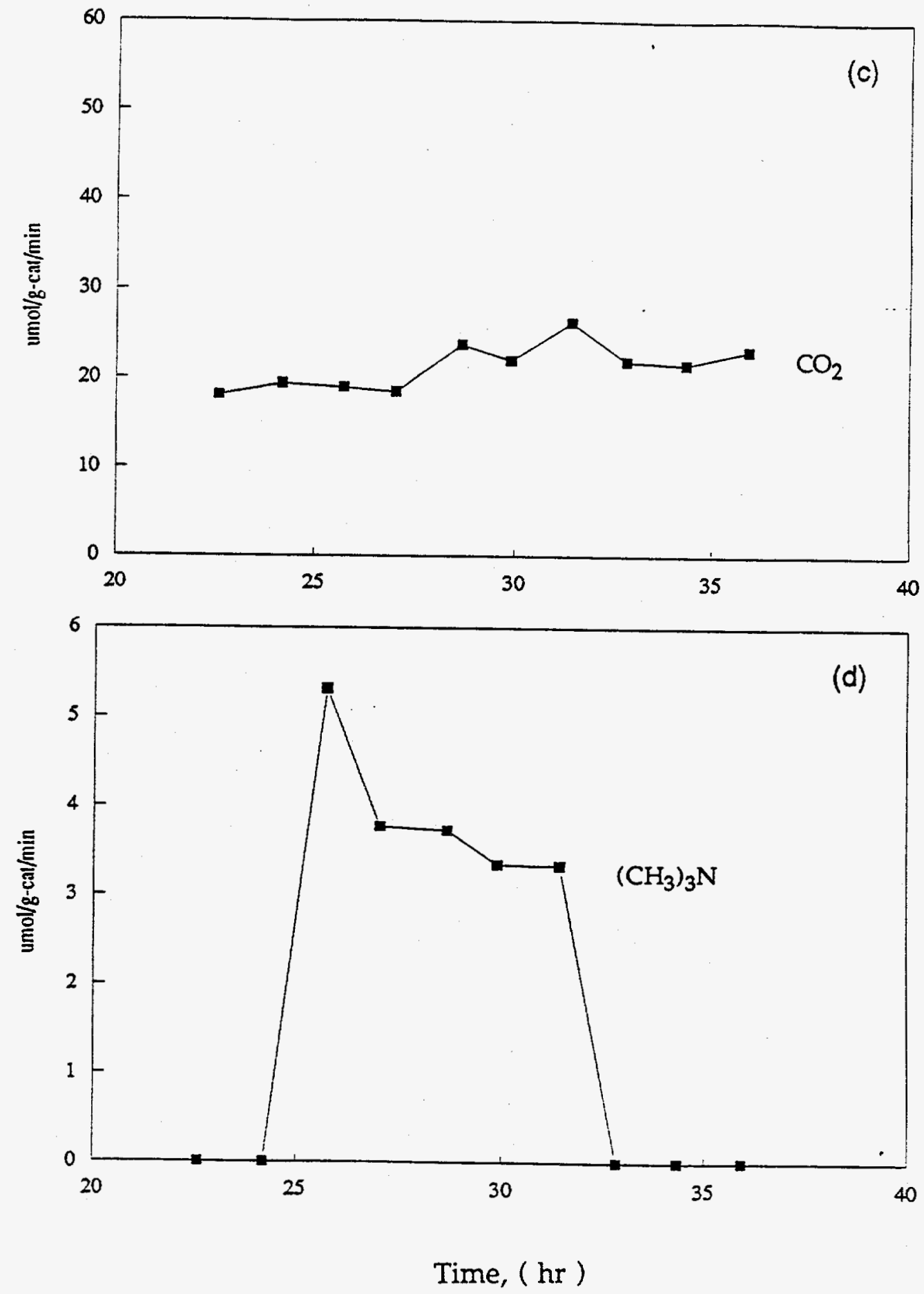

Figure F4 (Continued) Formation Rates of (c) $\mathrm{CO}_{2}$ and (d) $\left(\mathrm{CH}_{3}\right)_{3} \mathrm{~N}$ without and with $\mathrm{CH}_{3} \mathrm{NO}_{2}$ Addition to $\mathrm{CO} / \mathrm{H}_{2}$ over $11 \mathrm{Co}-\mathrm{IW}-\mathrm{B}$ 

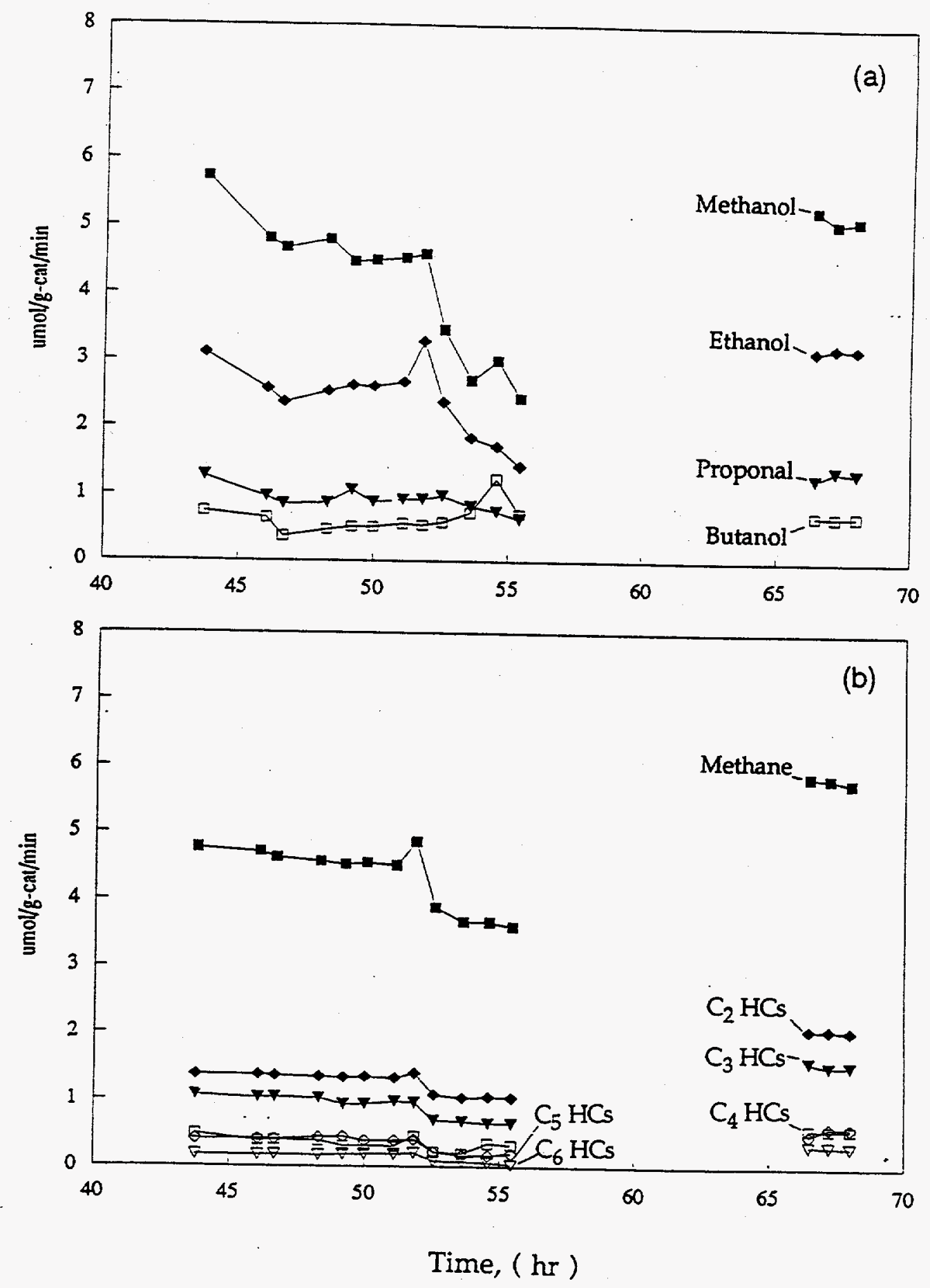

Figure F5 Formation Rates of (a) Alcohols and (b) Hydrocarbons without and with $\mathrm{CH}_{3} \mathrm{NO}_{2}$ Addition to $\mathrm{CO} / \mathrm{H}_{2}$ over $11 \mathrm{Co}-\mathrm{CP}-\mathrm{A}$ 

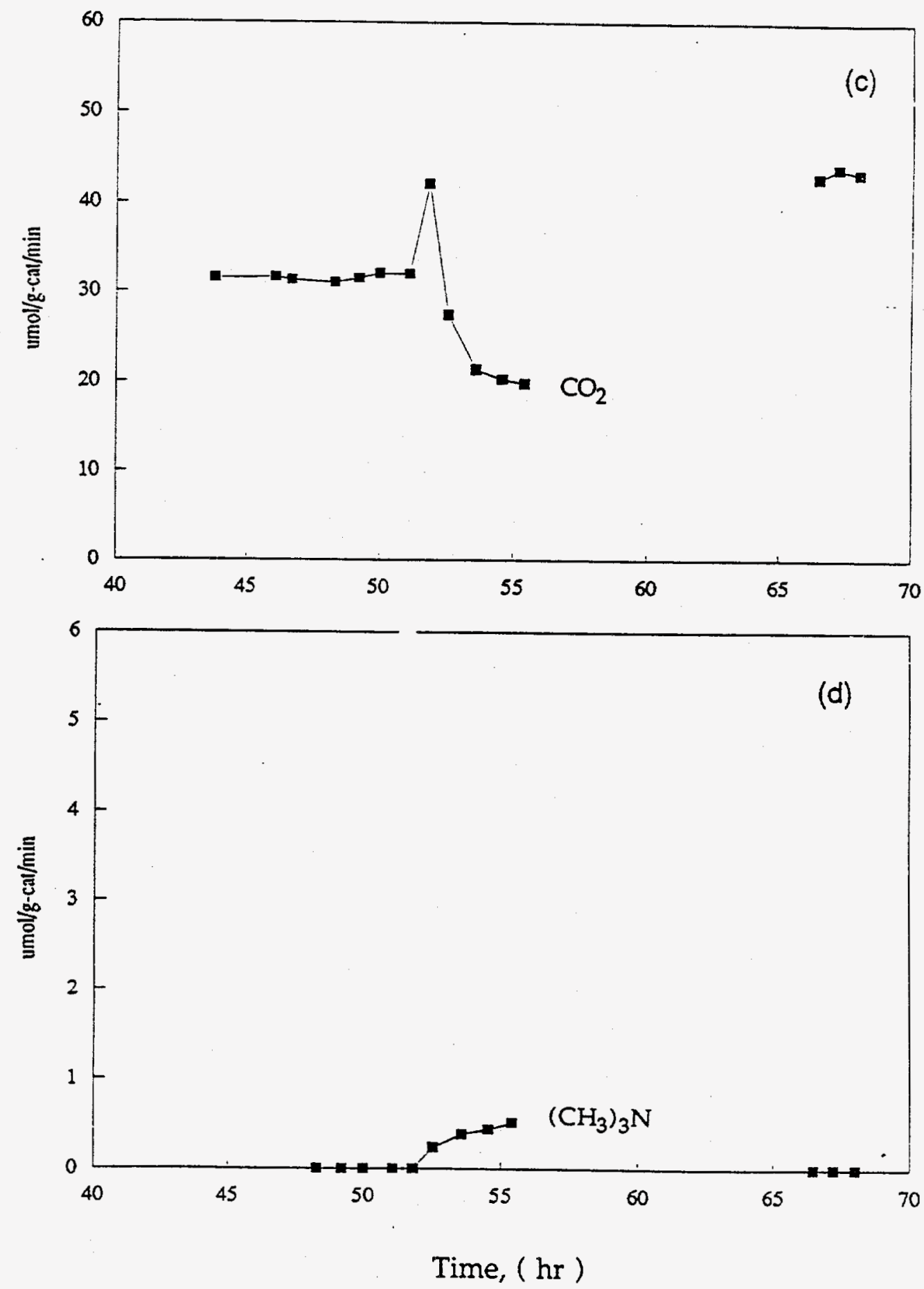

Figure F5 (Continued) Formation Rates of (c) $\mathrm{CO}_{2}$ and (d) $\left(\mathrm{CH}_{3}\right)_{3} \mathrm{~N}$ without and with $\mathrm{CH}_{3} \mathrm{NO}_{2}$ Addition to $\mathrm{CO} / \mathrm{H}_{2}$ over $11 \mathrm{Co}-\mathrm{CP}-\mathrm{A}$ 

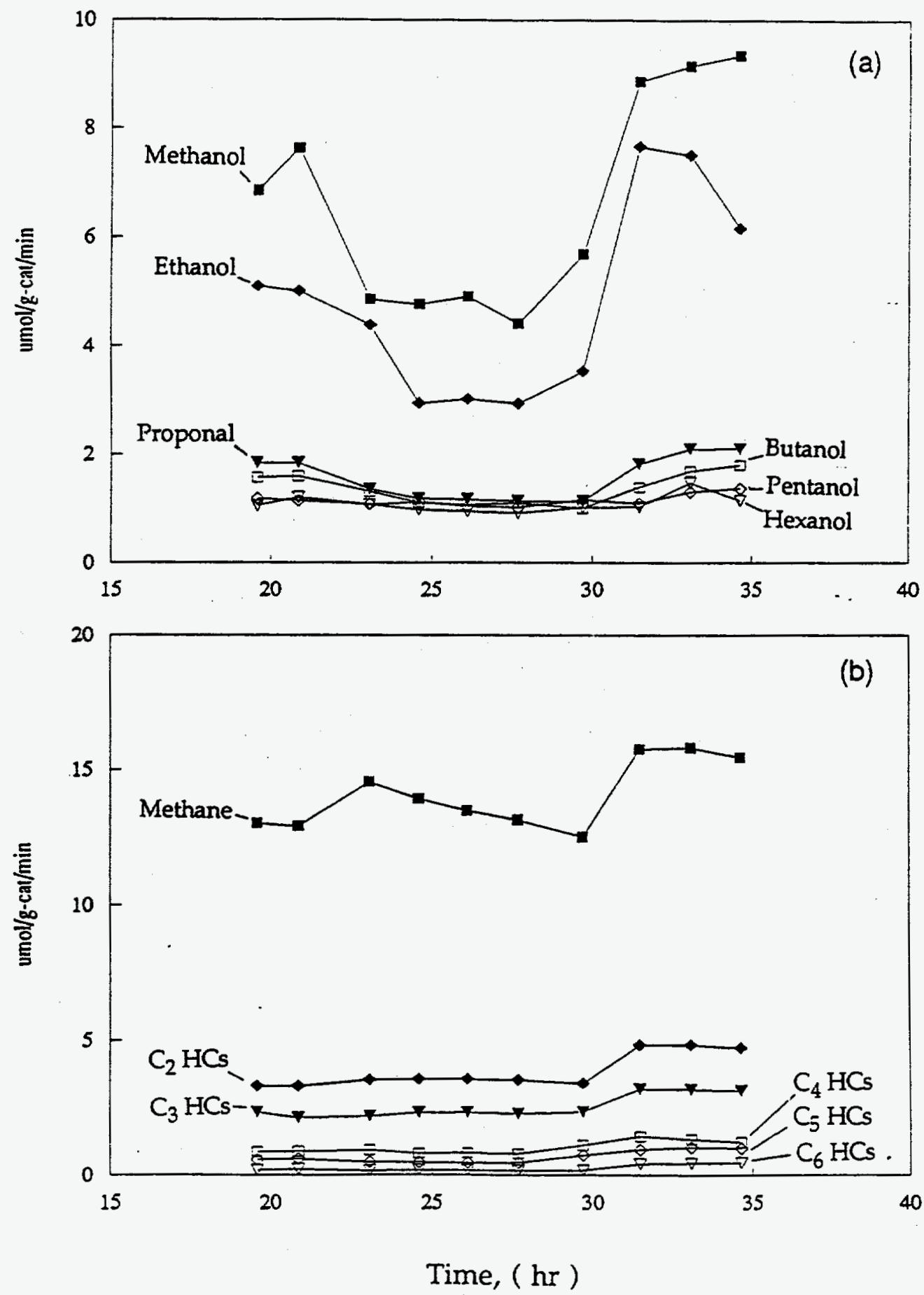

Figure F6 Formation Rates of (a) Alcohols and (b) Hydrocarbons without and with $\mathrm{CH}_{3} \mathrm{NO}_{2}$ Addition to $\mathrm{CO} / \mathrm{H}_{2}$ over $11 \mathrm{Co}-\mathrm{CP}-\mathrm{B}$ 

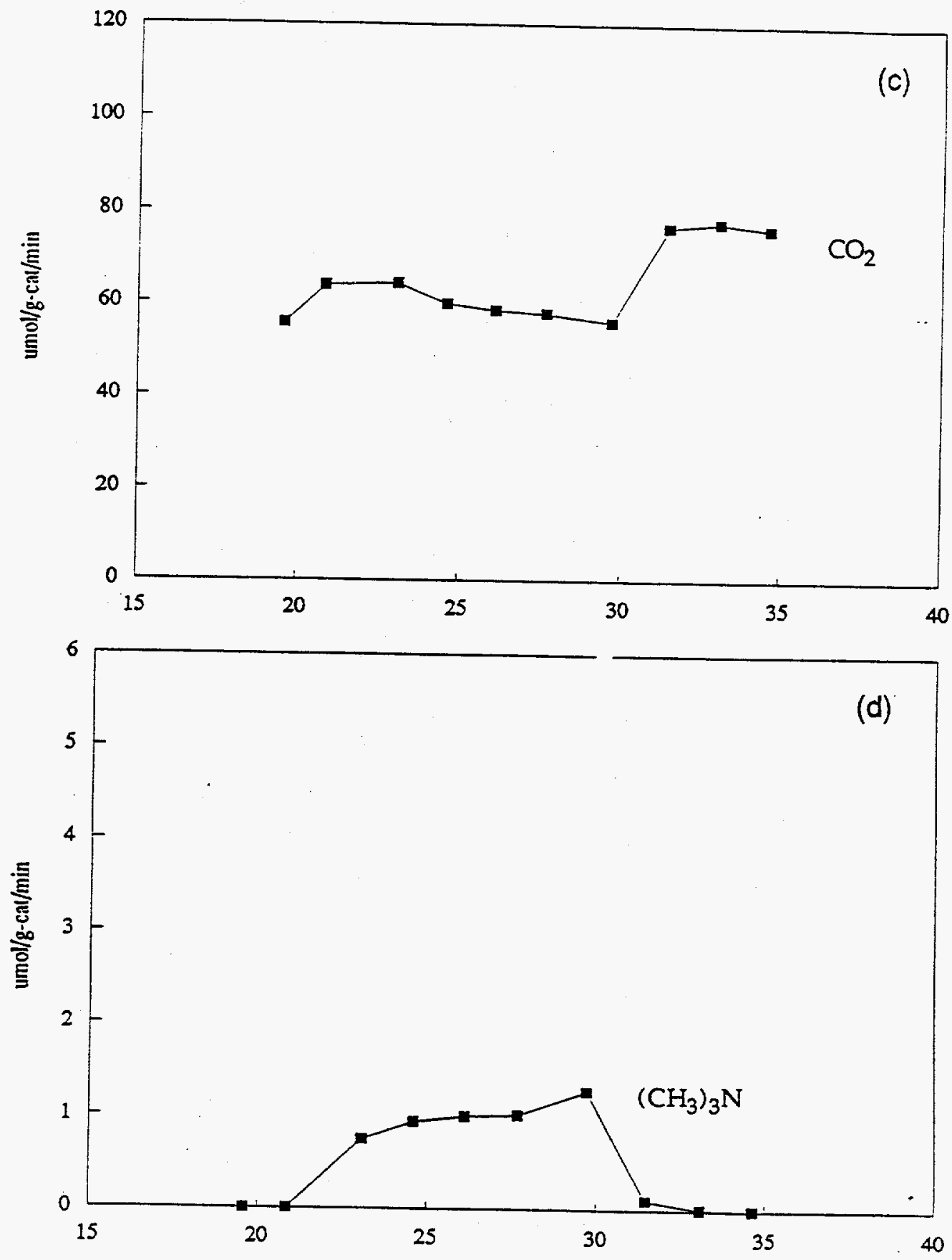

Time, ( hr )

Figure F6 (Continued) Formation Rates of (c) $\mathrm{CO}_{2}$ and (d) $\left(\mathrm{CH}_{3}\right)_{3} \mathrm{~N}$ without and with $\mathrm{CH}_{3} \mathrm{NO}_{2}$ Addition to $\mathrm{CO} / \mathrm{H}_{2}$ over $11 \mathrm{Co}-\mathrm{CP}-\mathrm{B}$ 


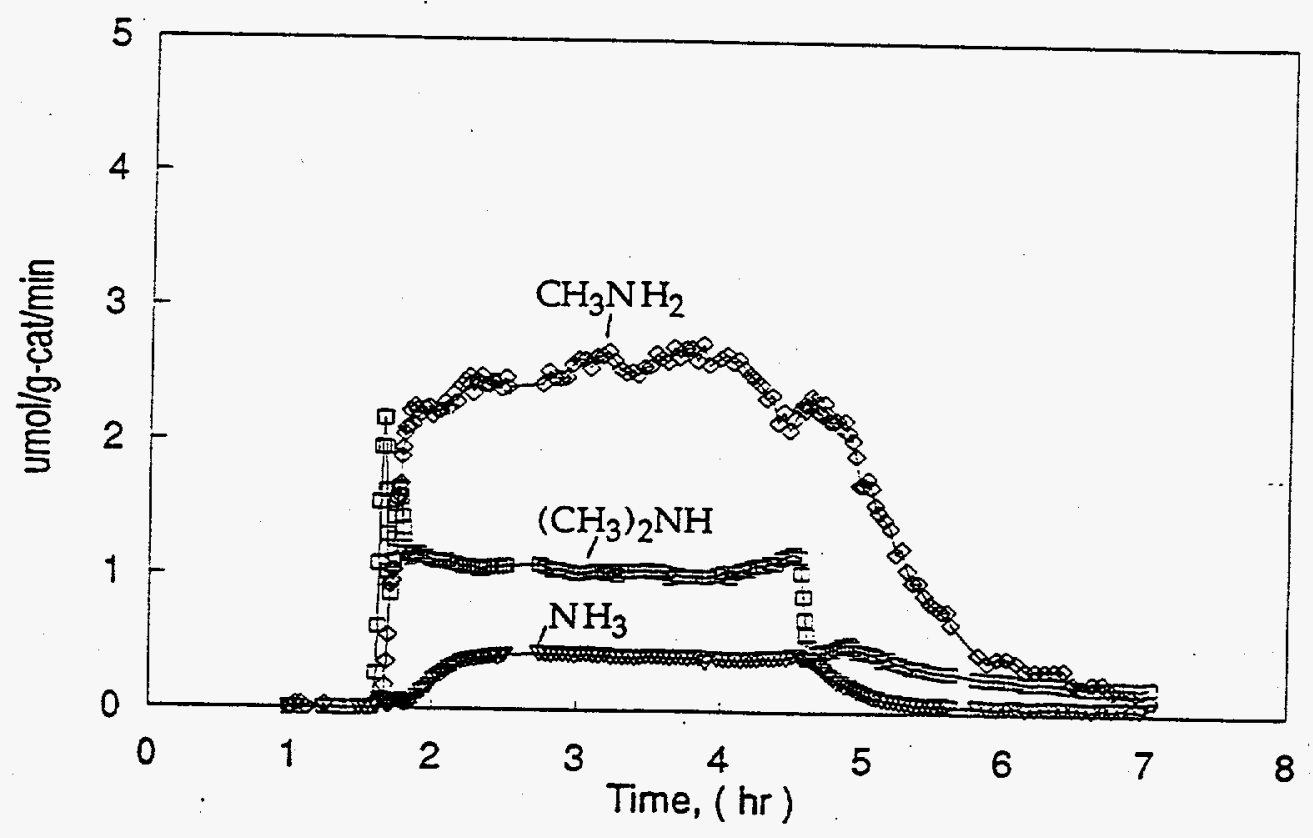

Figure F7 Formation of $\left(\mathrm{CH}_{3}\right)_{2} \mathrm{NH}, \mathrm{CH}_{3} \mathrm{NH}_{2}$ and $\mathrm{NH}_{3}$ during the Addition of $\mathrm{CH}_{3} \mathrm{NO}_{2}$ to $\mathrm{CO} / \mathrm{H}_{2}$ over 00Co-IW-A

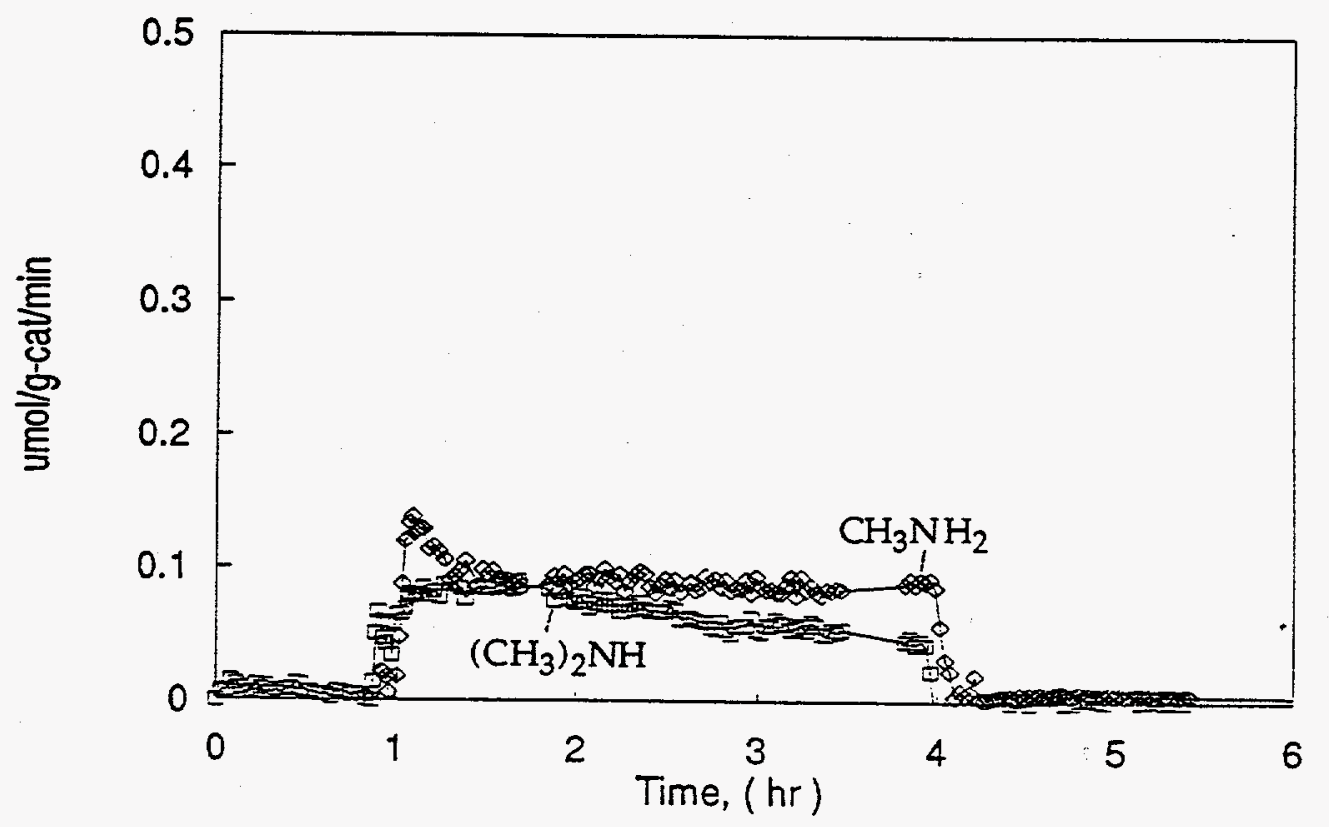

Figure F8 Formation of $\left(\mathrm{CH}_{3}\right)_{2} \mathrm{NH}, \mathrm{CH}_{3} \mathrm{NH}_{2}$ and $\mathrm{NH}_{3}$ during the Addition of $\mathrm{CH}_{3} \mathrm{NO}_{2}$ to $\mathrm{CO} / \mathrm{H}_{2}$ over $05 \mathrm{Co}-\mathrm{IW}-\mathrm{A}$ 


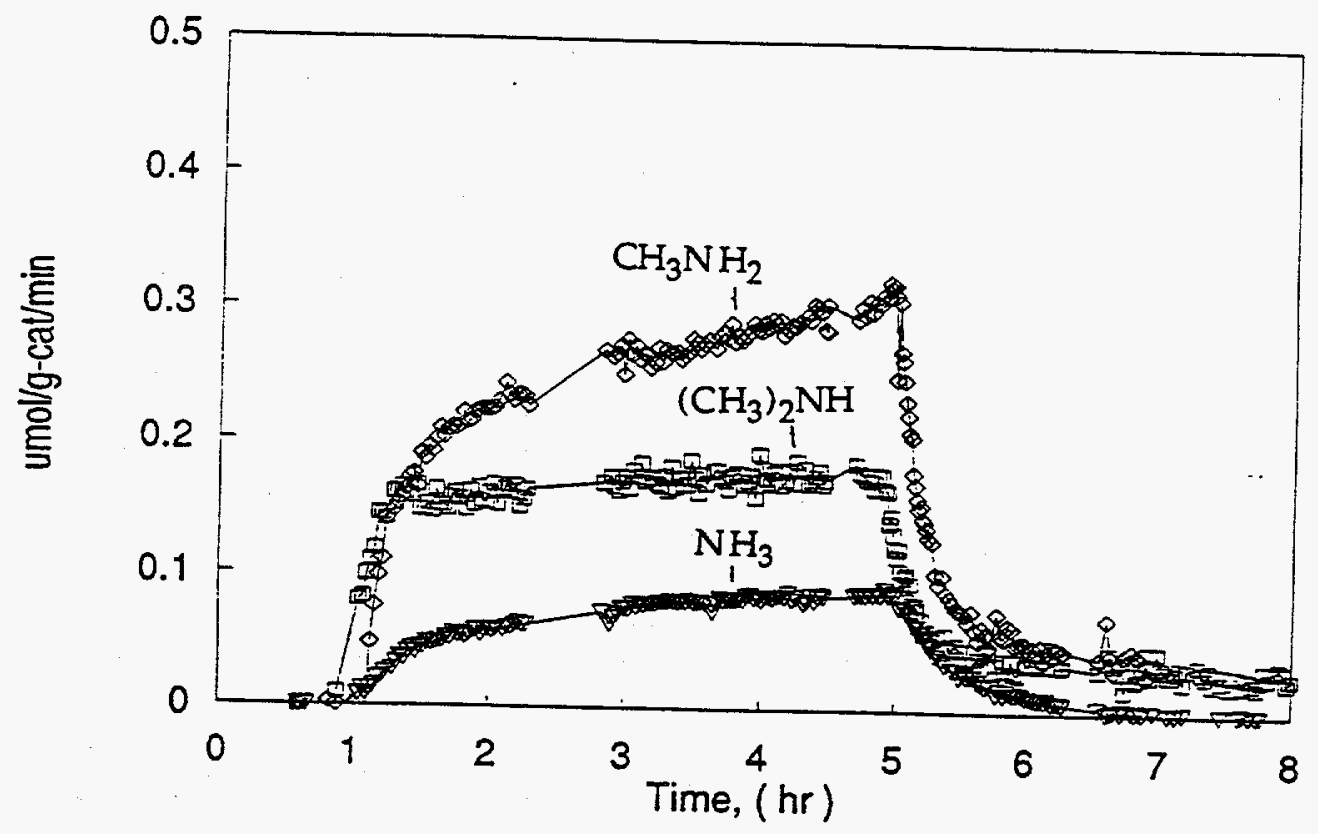

Figure F9 Formation of $\left(\mathrm{CH}_{3}\right)_{2} \mathrm{NH}, \mathrm{CH}_{3} \mathrm{NH}_{2}$ and $\mathrm{NH}_{3}$ during the Addition of $\mathrm{CH}_{3} \mathrm{NO}_{2}$ to $\mathrm{CO} / \mathrm{H}_{2}$ over $11 \mathrm{Co}-\mathrm{IW}-\mathrm{A}$

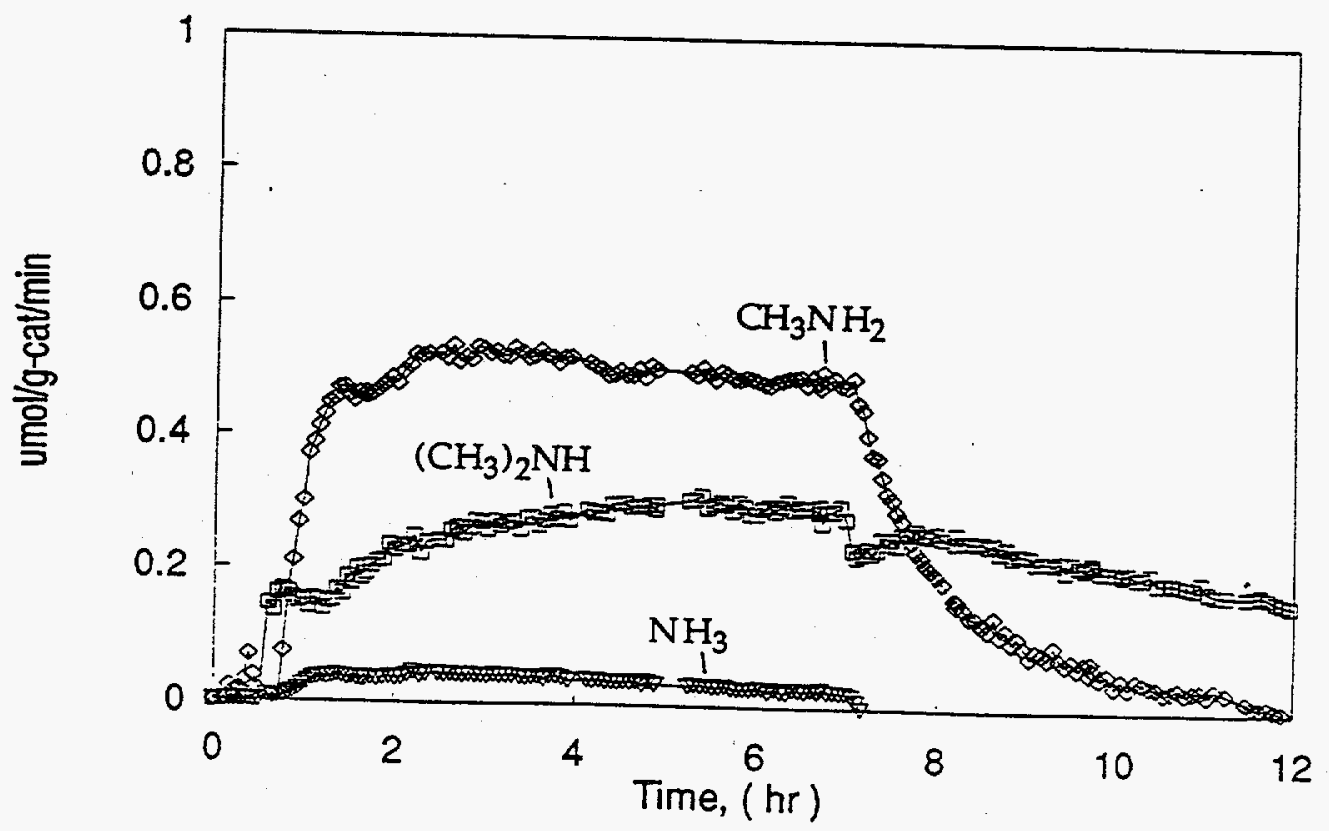

Figure F10 Formation of $\left(\mathrm{CH}_{3}\right)_{2} \mathrm{NH}, \mathrm{CH}_{3} \mathrm{NH}_{2}$ and $\mathrm{NH}_{3}$ during the Addition of $\mathrm{CH}_{3} \mathrm{NO}_{2}$ to $\mathrm{CO} / \mathrm{H}_{2}$ over $11 \mathrm{Co}-\mathrm{IW}-\mathrm{B}$ 


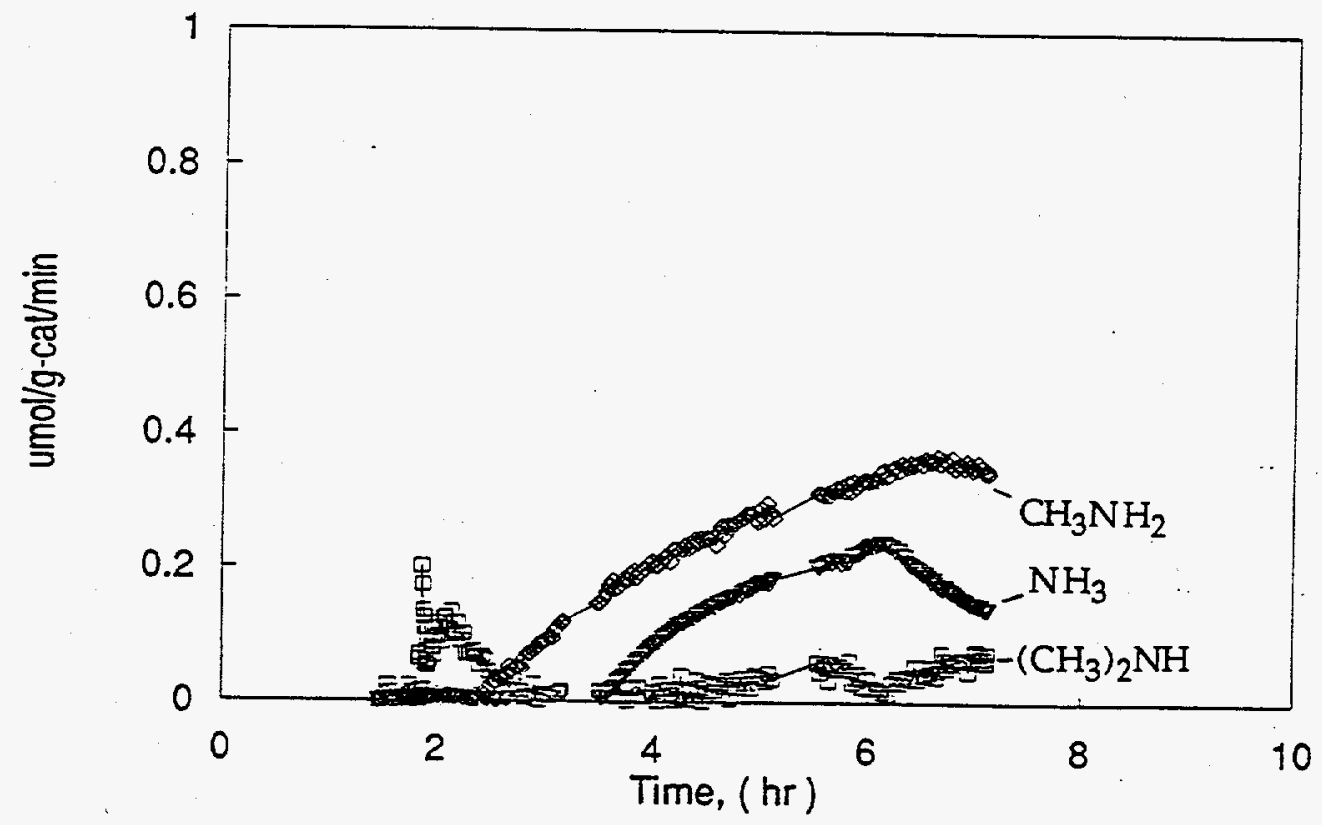

Figure F11 Formation of $\left(\mathrm{CH}_{3}\right)_{2} \mathrm{NH}, \mathrm{CH}_{3} \mathrm{NH}_{2}$ and $\mathrm{NH}_{3}$ during the Addition of $\mathrm{CH}_{3} \mathrm{NO}_{2}$ to $\mathrm{CO} / \mathrm{H}_{2}$ over $11 \mathrm{Co}-\mathrm{CP}-\mathrm{A}$

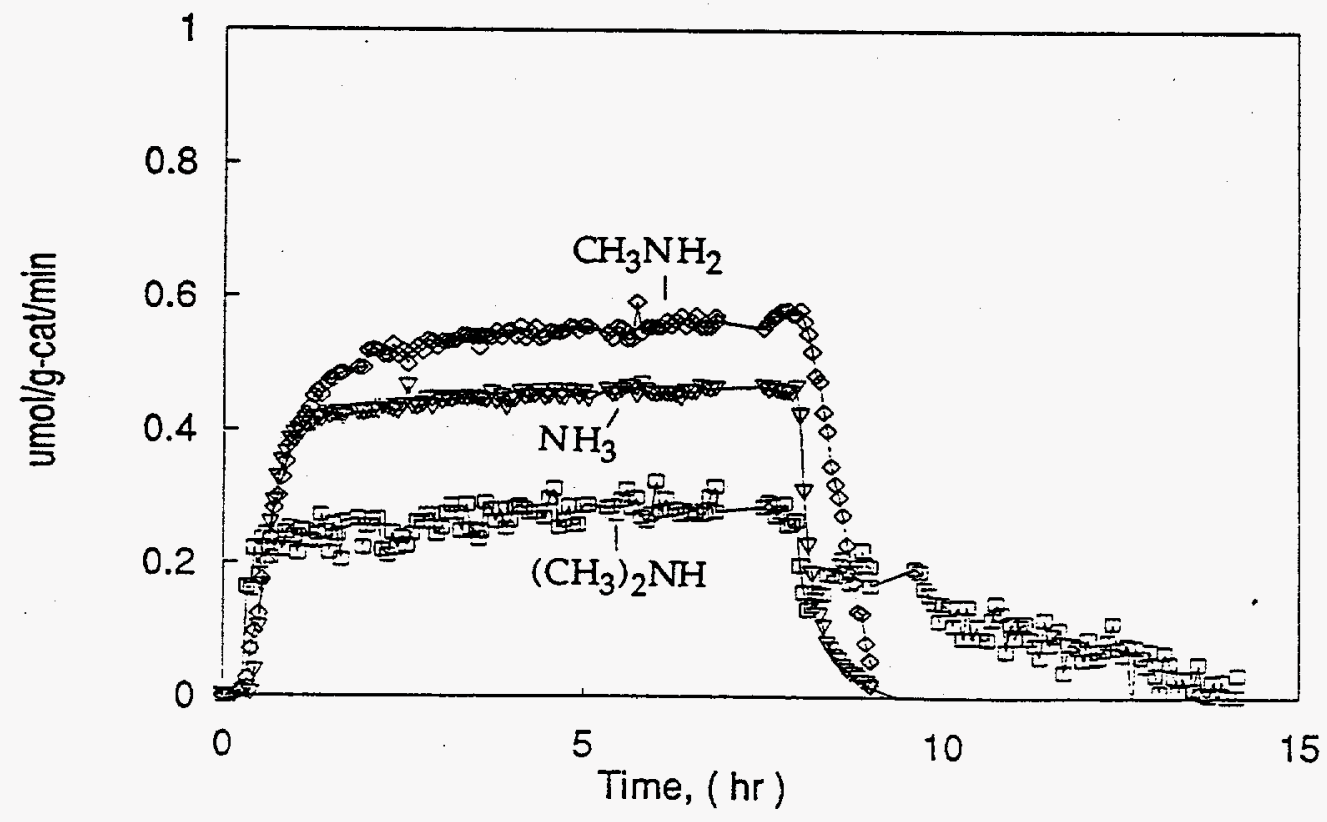

Figure F12 Formation of $\left(\mathrm{CH}_{3}\right)_{2} \mathrm{NH}, \mathrm{CH}_{3} \mathrm{NH}_{2}$ and $\mathrm{NH}_{3}$ during the Addition of $\mathrm{CH}_{3} \mathrm{NO}_{2}$ to $\mathrm{CO} / \mathrm{H}_{2}$ over $11 \mathrm{Co}-\mathrm{CP}-\mathrm{B}$ 
BIBLIOGRAPHY 


\section{BIBLIOGRAPHY}

1. Mills, G. A., Status and Future Opportunities for Conversion of Synthesis Gas to Liquid Energy Fuels: Final Report, NREL/TP-421-5150 (Newark, Delaware: University of Delaware, May, 1993).

2. Forzatti, P., Tronconi, E. and Pasquon, I., "Higher Alcohol Synthesis," Catal. Rev.-Sci. Eng., Vol. 33, No. 1\&2 (1991), pp. 109-168.

3. Guczi, L., ed., Studies in Surface Science and Catalysis: New Trends in CO Activation, "Classical and Non-classical Routes for Alcohol Synthesis, by R. G. Herman" (Elsevier, 1991), Chapter 7.

4. Kaliaguine, S., ed., Keynotes in Energy-Related Catalysis; Studies in Surface Science and Catalysis, Volume 35 "Heterogeneous Carbon Monoxide Hydrogenation, by A. Kiennemann, and J. P. Hindermann" (Amsterdam-Oxford-New York-Tokyo: Elsevier, 1988), Chapter 4.

5. Xu, X., Doesburg, E. B. M. and Scholten, J. J. F. "Synthesis of Higher Alcohols from Syngas - Recently Patented Catalysts and Tentative Ideas on the Mechanism," Catalysis Today Vol. 2 (1987), pp. 125-170.

6. Dalmon, J. A., Chaumette, P. and Mirodatos, "Higher Alcohols Synthesis on Cobalt Based Model Catalysts," Catalysis Today Vol. 15, (1992), pp. 101-127.

7. Lee, G. v. d. and Ponec, V., "On Some Probelems of Selectivity in Syngas Reactions on the Group VIII Metals," Catal. Rev. - Sci. Eng. Vol. 29, No. 2\&3, (1987), pp. 183-218.

8. Ghiotti, G. and Boccuzzi, F., "Chemical and Physical Properties of Copper-Based Catalysts for CO Shift Reaction and Methanol Synthesis," Catal. Rev. - Sci. Eng. Vol. 29, No. 2\&3, (1987), pp. 158-182.

9. Lietti, I., Tronconi, E., and Forzatti, P., "Surface Properties of $\mathrm{ZnO}$ Based Catalysts and Related Mechanistic Features of the Higher Alcohoi Synthesis by FT-IR Spectroscopy and TPSR," L. Mol. Catal. Vol. 55, (1989), pp. 43-54.

10. $\mathrm{Xu}, \mathrm{X} .$, Mausbeck, D. and Scholten, J. J. F., "A Study of the $\mathrm{Cu} / \mathrm{Co}$ Catalysts for the Synthesis of Higher Alcohol from Syngas," Catalysis Today Vol. 10, (1991), pp. 429-432. 
11. Morterra, C., Zecchina, A. and Costa, G., ed., Structure and Reactivity of Surfaces, "Electron Microscopy and Microdiffraction Study of the Interaction of $\mathrm{Pd}$ with $\mathrm{SiO}_{2}$, by J. R. Jennings and M. S. Spencer," (Elsevier Science Publishers B.V., 1989), pp. 559-565.

12. Luth, H., Rubloff, G. W. and Grobman, W. D., "Chemisorption and Decomposition Reactions of Oxygen-Containing Organic Molecules on Clean Pd Surfaces Studied by UV Photomission," Surface Science, Vol. 63, (1977), pp. 325-338.

13. Fleisch, T. H., Hicks, R.F. and Bell, A. T., "An XPS Study of MetalSupport Interaction on $\mathrm{Pd} / \mathrm{SiO}_{2}$ and $\mathrm{Pd} / \mathrm{La}_{2} \mathrm{O}_{3}$, I. Catal. Vol. 87, (1984), pp. 398-413.

14. Hicks, R. F. and Bell, A. T., "Kinetics of Methanol and Methane Synthesis over $\mathrm{Pd} / \mathrm{SiO}_{2}$ and $\mathrm{Pd} / \mathrm{La}_{2} \mathrm{O}_{3}$," L. Catal., Vol. 91, (1985), pp. 104115.

15. Chinchen, G. C., Denny, P. J., Parker, D. G., Spencer, M. S. and Whan, D. A., "Mechanism of Methanol Synthesis from $\mathrm{CO}_{2} / \mathrm{CO} / \mathrm{H}_{2}$ Mixtures over Copper/Zinc Oxide/Alumina Catalysts: Use of ${ }^{14} \mathrm{C}$-Labeled Reactants," Appl. Catal., Vol. 30, (1987), 333-338.

16. Kummer, J. T. and Emmett, P. H., "Fischer-Tropsch Synthesis Mechanism Studies. The Addition of Radioactive Alcohols to the Synthesis Gas," I. Am. Chem. Soc. Vol. 75, (1953), pp. 5177-5183.

17. Ward, J. W., ed. Catalysis, "Fischer-Tropsch Synthesis: Comparison of Production Selectivity and ${ }^{14} \mathrm{C}$ Labeled Ethanol Incorporation at One and Seven Atmospher Conditions, by H. Dabbagh, L. M. Tau, J. Halasz, and B. H. Davis" (Amlsterdam: Elsiver Science Publishers B.V., 1988), Pp. 61-72.

18. Nunan, J. G., Boydan, C. E., Klier, K., Smith, K. J. Young, C. and Herman, R. G., "Methanol and $C_{2}$ Oxygenate Synthesis over Cesium Doped $\mathrm{Cu} / \mathrm{ZnO}$ and $\mathrm{Cu} / \mathrm{ZnO} / \mathrm{Al}_{2} \mathrm{O}_{3}$ Catalysts: A Study of Selectivity and 13.C Incorporation Patterns," I. Catal. Vol. 113, (1988), pp. 410-433.

19. Wang, H., Liu, J., Fu, J., Wan, H. and Tsai, K., "Study on the Mechanism of Ethanol Synthesis from Syngas by In-Situ Chemical Trapping and Isotopic Exchange Reactions," Catalysis Letters, Vol. 12, (1992), pp. 87-96. 
20. Chuang, S. C., Tian, Y. H., Goodwin, J. G., Jr. and Wender, I., "The Use of Probe Molecules in the Study of $\mathrm{CO}$ Hydrogenation over $\mathrm{SiO}_{2}-$ Supported Ni, Ru, Rh, and Pd," I. Catal. Vol. 96, (1985), pp. 396-407:

21. Tatsumi, T., Muramatsu, A., Yokota, K. and Tominaga, H., "Mechanistic Study on the Alcohol Synthesis over Molybdenum Catalysts," L. Catal., Vol. 115, (1989), pp. 388-398.

22. Kiennemann, A., Diagne, C., Hindermann, J. P., Chaumette, P. and Courty, $\mathrm{P}$., "Higher Alcohol Synthesis from $\mathrm{CO}+2 \mathrm{H}_{2}$ on Cobalt-Copper Catalyst, Use of the Probe Molecules and Chemical Trapping in the Study of the Reaction Mechanism," Appl. Catal. Vol. 53, (1989), pp. 197-216.

23. Slivinsky, E. V., Rumyantsev, V. U., Voitsekhovsky, Y. P., Zvezdkina, L. I. and Loktv, S. M., "Synthesis of Oxygenated Compounds from Carbon Monoxide and Hydrogen through Addition of Substituted Acetylenes," J. Catal., Vol. 123, (1990), pp. 333-340.

24. Adesina, A. A., Hudgins, R. R. and Silveston, P. L., "Effect of Ethene Addition during the Fischer-Tropsch Reaction," Applied Catalysis, Vol. 62, (1990), pp. 295-308.

25. Cavalcanti, F. A. P., Oukaci, R., Wender, I. and Blackmond, D. G., "Probe Molecule Studies of $\mathrm{CO}$ Hydrogenation over $\mathrm{Ru} / \mathrm{SiO}_{2}$," I. Catal. Vol. 123, (1990), pp. 260-269.

26. Cavalcanti, F. A. P., Oukaci, R., Wender, I. and Blackmond, D. G., "Nitromethane as a Probe Molecule for CO Hydrogenation over $\mathrm{Ru} / \mathrm{SiO}_{2}$," I. Catal., Vol. 123, (1990), pp. 270-274.

27. Cavalcanti, F. A. P., Oukaci, R., Wender, I. and Blackmond, D. G., " $\mathrm{CH}_{3} \mathrm{NO}_{2}$ Addition to $\mathrm{CO}$ Hydrogenation over $\mathrm{Ru} / \mathrm{KY}$ Catalyst," L. Catal., Vol. 128, (1990), pp. 311-319.

28. Tronconi, E., and Groppi, G., "Addition of Propene to Carbon Monoxide-Hydrogen in Higher Alcohol Synthesis over Unpromoted and Cesium-Promoted ZnCrO Catalysts," Applied Catalysis A: General, Vol. 79, (1991), pp. 181-190.

29. Takeuchi, A. and Katzer, J. R., "Ethanol Formation Mechanism from $\mathrm{CO}+\mathrm{H}_{2}$," J. Phys. Chem., Vol. 86, (1982), pp. 2438-2441. 
30. Klier, K., Heterogeneous Catalysis, "Methanol and Low Alcohol Synthesis," (Texas A\&M University Press, 1984), pp. 252-282.

31. Vedage, G. A., Himmelfarb, P. B., Simmons, G. W. and Klier, K., "Alkali-Promoted Copper-Zinc Oxide Catalysts for Low Alcohol Synthesis, Solid State Chemistry in Catalysis," ACS Symposium Series, Vol. 279, (1985), pp. 295-312.

32. Elliott, D. J. and Peenella, F., "Mechanism of Ethanol Formation from Synthesis $\mathrm{Gas}$ over $\mathrm{CuO} / \mathrm{ZnO} / \mathrm{Al}_{2} \mathrm{O}_{3}$," L. Catal. 114, (1988), pp. 90-99.

33. - Nunan, J. G., Bogdan, C. E., Klier, K., Smith, K. J., Young, C-W and Herman, R.G., "Higher Alcohol and Oxygenate Synthesis over CesiumDoped Cu/ZnO Catalysts, I. Catal., Vol. 116, (1989), 195-221.

34. Rabo, J. A., Risch, A. P. and Poutsma, M. L., "Reactions of Carbon Monoxide and Hydrogen on $\mathrm{Co}, \mathrm{Ni}, \mathrm{Ru}$, and Pd Metals," I. Catal. Vol, 53, (1978), pp. 295-311.

35. Watson, P. R. and Somorjai, G. A., "The Formation of OxygenContaining Organic Molecules by the Hydrogenation of Carbon Monoxide Using a Lanthanum Rhodate Catalyst," L. Catal., Vol. 74, (1982), pp. 282-295.

36. Hackenbruch, J., Keim, W., Roeper, M. and Strutz, H., "Mechanistic Considerations for the Formation of Oxygenated Species in FischerTropsch Synthesis," L. Mol. Catal., Vol. 26, No. 1, (1984), pp. 129-133.

37. Favre, T. L. F., van der Lee, G. and Ponec, V., "Heterogeneous Catalytic Insertion Mechanism of the $C_{2}$ Oxygenate Formation," I. Chem. Soc. Chem. Commun. (1985), pp. 230-231.

38. Tatsumi, T., Muramatsu, A., Yokota, K. and Tominaga, H., "Mechanism of CO Hydrogenation to Alcohol on Potassium-Promoted $\mathrm{Mo} / \mathrm{SiO}_{2}$, L. of Mol. Catal., Vol. 41, (1987), pp. 385-389.

39. Maznec, T. J., "On the Mechanism of Higher Alcohol Formation over Metal Oxide Catalysts," L. Catal. Vol. 98, (1986), 115-125.

40. Courty, P., Durand, D., Freund, E. and Sugier, A., " $C_{1}-C_{6}$ Alcohols from Synthesis Gas on Copper-Cobalt Catalysts," L. Mol. Catal. Vol. 17, (1982), pp. 241-254. 
41. Courty, P., Arlie, J. P., Convers, A., Mikitenko, P. and Sugier A., " $\mathrm{C}_{1}-\mathrm{C}_{6}$ Alcohols from Syngas," Hydrocarbon Processing, (November, 1984), pp. 105-108.

42. Sugier, A., Freund, E. and Le Page, J-F., Production of Alcohols from Synthesis Gases. U.S. Patent No. 4346 179, (1982).

43. Chaumette, P., Courty, P., Durand, D., Grandvallet, P. and Travers, C., Alcohol Manufacturing Process and Catalyst therefor. U.K. Patent No. GB 2158 730A, (1985).

44. Courty, P., Durand, P., Sugier, A. and Freund, E., Process for Manufacturing a Mixture of Methanol and Higher Alcohols from Synthesis Gas. U.S. Patent No. 4659 742, (1987).

45. Di Cosimo, J. I., and Apestegufa, C. R., "Preparation of Ternary $\mathrm{Cu} / \mathrm{Co} / \mathrm{Al}$ Catalysts by the Amorphous Citrate Process, I. Decomposition of Solid Amorphous Precursors," I. Catal., Vol. 116, (1989), pp. 71-81.

46. Baker, J. E., Burch, R., and Golunski, S. E., "Synthesis of Higher Alcohols over Copper/Cobalt Catalysts, Influence of Preparation Procedures on the Activity and Selectivity of $\mathrm{Cu} / \mathrm{Co} / \mathrm{ZnO} / \mathrm{Al}$ Mixed Oxide Catalysts," Appl. Catal. Vol. 53, (1989), pp. 279-297.

47. Baker, J. E., Burch, R., Hibble, S. J., and Loader, P. K., "Properties of Silica-Supported $\mathrm{Cu} / \mathrm{Co}$ Bimetallic Catalysts in the Synthesis of Higher Alcohols," Appl. Catal. 65, (1990), pp. 281-292.

48. Baker, J. E., Burch, R., and Niu, Y., "Investigation of $\mathrm{CoAl}_{2} \mathrm{O}_{4}$, $\mathrm{Cu} / \mathrm{CoAl} \mathrm{O}_{4}$ and $\mathrm{Co} / \mathrm{CoAl} \mathrm{O}_{4}$ Catalysts for the Formation of Oxygenates from a Carbon Monoxide-Carbon Dioxide-Hydrogen Mixture," Appl. Catal. Vol. 73, (1991), pp. 135-152.

49. - Xu, X., and Scholten, J. J. F., "Stability of Copper/Cobalt Catalysts for the Synthesis of Higher Alcohols from Syngas," Appl. Catal. Vol. 82, (1992), pp. 91-109. .

50. Cosimo, J. I. Di, Marchi, A. J., and Apestegufa, C. R., "Preparation of Ternary $\mathrm{Cu} / \mathrm{Co} / \mathrm{Al}$ Catalysts by the Amorphous Citrate Process, II. The Effect of the Decomposition-Calcination Atmosphere," L. Catal., Vol. 134, (1992), pp. 594-607.

51. Emmett, P. H., ed., Catalysis, III. "Synthesis of Methanol; by G. Natta, 
1955" pp. 349-411.

52. Chinchen, G. C., Denny, P. J., Jennings, J. R., Spencer, M. S. and Waugh, K. C., "Synthesis of Methanol," Applied Catalysis, Vol. 36, (1988), 1-65.

53. Kung, H. H., "Methanol Synthesis," Catal. Rev. - Sci. Eng., Vol. 22, No. 2, (1980), pp. 235-259.

54. Robinson, W. R. A. M. and Mol, J. C., "Structure and Activity in $\mathrm{CO} / \mathrm{H}_{2}$ of $\mathrm{Cu} / \mathrm{ZnO} / \mathrm{Al}_{2} \mathrm{O}_{3}$ Methanol Synthesis Catalysts," Applied Catalysis, Vol. 60, (1990), pp. 61-72.

55. Robinson, W. R. A. M. and Mol, J. C., "Copper Surface Area and Activity in $\mathrm{CO} / \mathrm{H}_{2}$ of $\mathrm{Cu} / \mathrm{ZnO} / \mathrm{Al}_{2} \mathrm{O}_{3}$ Methanol Synthesis Catalysts," Applied Catalysis, Vol. 60, (1990), pp. 73-86.

56. Waugh, K. C., "On the Junction Effect Theory of Activity in Methanol Synthesis Catalysts," Catalysis Letters, Vol. 7, (1990), pp. 345-350.

57. Greaf, G. H., Stamhuis, E. J. and Beenackers, A. A. C. M., "Kinetics of Low-Pressure Methanol Synthesis," Chem. Eng. Sci., Vol. 43, No. 12, (1988), pp. 3185-3195.

58. Himelfarb, P. B., Simmons, G. W., Klier, K. and Herman, R. G., "Precursors of the Copper-Zinc Oxide Methanol Synthesis Catalysts," I. Catal. Vol. 93, (1985), pp. 442-450.

59. Akhter, S., Cheng, W. H., Lui, K. and Kung, H. H., "Decomposition of Methanol, Formaldehyde, and Formic Acid on Nonpolar(1010), Stepped (5051), and (0001) Surfaces of $\mathrm{ZnO}$ by Temperature-Programed Decomposition," L. Catal., Vol. 85, (1984), pp. 437-456.

60. Takeuchi, A. and Katzer, J. R., "Mechanism of Methanol Formation," L.Phys. Chem. Vol. 85, (1984), pp. 437-456.

61. Herman, R. G., Klier, K., Simmons, G. W., Finn, B. P. and Bulko, J. B., "Catalytic Synthesis of Methanol from CO/ $\mathrm{H}_{2}$," L. Catal. Vol. 56, (1979), pp. 407-429.

62. Poutsma, M. L., Elek, L. F., Ibarbia, P. A., Risch, A. P. and Rabo, J. A., "Selective Formation of Methanol from Synthesis Gas over Palladium Catalysts," L. Catal. Vol. 52, (1978), pp. 157-168. 
63. Fajula, F., Anthony, R. G. and Lunsford, J. H., "Methane and Methanol Synthesis over Supported Palladium Catalysts," J. Catal., Vol. 73, (1982), pp. 237-256.

64. Driessen, J. M., Poels, E. K., Hindermann, J. P. and Ponec, V., "On the Selectivity of Palladium Catalyst in Synthesis Gas Reactions," L. Catal. Vol. 82, (1983), 26-34.

65. Hicks, R. F. and Bell, A. T., "Effects of Metal-Support Interaction on the Hydrogenation of $\mathrm{CO}$ over $\mathrm{Pd} / \mathrm{SiO}_{2}$ and $\mathrm{Pd} / \mathrm{La}_{2} \mathrm{O}_{3}$," J. Catal., Vol. 90, (1984), pp. 205-220.

66. Kelly, K. P., Tatsumi, T., Uematsu, T., Driscoll, D. J. and Lunsford, J. H., "Methanol Synthesis over Palladium Supported on Silica," I. Catal. Vol. 101, (1986), pp. 396-404.

67. Morterra, A. Z. and Costa, G., ed., Structure and Reactivity of Surfaces, "Compaison of Copper and Palladium Catalysts in the Synthesis of Methanol from CO/ $\mathrm{H}_{2}$ Mixtures, by J. R. Jennings and M. S. Spencer," (Elsevier Science Publishers B.V., 1989), pp. 515-524.

68. Chinchen, G. C., Spencer, M. S., Waugh, K. C. and Whan, D. A., Faraday Symp. Chem. Soc, paper 18, Vol. 21, (1986).

69. He, M. Y., White, J. M. and Ekerdt, J. G., " $\mathrm{CO}$ and $\mathrm{CO}_{2}$ Hydrogenation over Metal Oxides: a Comparison of $\mathrm{ZnO}, \mathrm{TiO}_{2}$ and $\mathrm{ZrO}_{2}$," L. Mol. Catal. Vol. 30, (1985), pp. 415-430.

70. Denise, B., Sneeden, R. P. A. and Hamon, C., "Methanol Hydrocarbonylation into Acetaldehyde Catalyzed by Cobalt and Two Different lodides," L. Mol. Catal. Vol. 17, (1982), pp. 339-347.

71. Wachs, I. E. and Madix, R. J., "The Selective Oxidation of $\mathrm{CH}_{3} \mathrm{OH}$ to $\mathrm{H}_{2} \mathrm{CO}$ on a Copper (110) Catalyst," L. Catal. Vol. 53, (1978), pp. 208-227.

72. Jennings, J. R. and Spencer, M. S., ed., Methanol Decomposition on $\mathrm{Pd} / \mathrm{ThO}_{2}$ : Relation Between Activity and Surface Structure, (Elsevier Science Publishers B.V., 1989), pp. 695-702.

73. Rieck, J.S. and Bell, A.T., "The Influence of Dispersion on the Interaction of $\mathrm{H}_{2}$ and $\mathrm{CO}$ with $\mathrm{Pd} / \mathrm{SiO}_{2}, "$ I. Catal. Vol. 103, (1987), pp. 4654. 
74. Ichikawa, S., Poppa, H. and Boudart, M., "Disproportionation of $\mathrm{CO}$ on Small Particles of Silica-Supported Palladium," L. Catal. Vol. 91, (1985), pp. 1-10.

75. Hicks, R.F., Yen, Q. and Bell, A. T., "Effects of Metal-Support Interactions on the Chemisorption of $\mathrm{H}_{2}$ and $\mathrm{CO}$ on $\mathrm{Pd} / \mathrm{SiO}_{2}$ and $\mathrm{Pd} / \mathrm{La}_{2} \mathrm{O}_{3}$," L. Catal., Vol. 89, (1984), pp. 498-510.

76. Ryndin, Y. A., Hicks, R. F. and Bell, A. T., "Effects of Metal-Support Interactions on the Synthesis of Methanol over Palladium," J. Catal., Vol. 70, (1981), pp. 287-297.

77. Wang, S., Moon, S. H. and Vannice, M. A., "The Effect of SMSI (Strong Metal-Support Interaction) Behavior on CO Adsorption and Hydrogenation on Pd Catalysts," I. Catal. Vol. 71, (1981), pp. 167-174.

78. Brown Bourzutschky, J. A., Homs, N. and Bell, A. T., "Hydrogenation of $\mathrm{CO}_{2}$ and $\mathrm{CO}_{2} / \mathrm{CO}$ Mixtures over Copper-Containing Catalysts," L. Catal. Vol. 124, (1990), pp. 73-85.

79. Chinchen, G. C. and Spencer, M. S., "Sensitive and Insensitive Reactions on Copper Catalysts: The Water-Gas Shift Reaction and Methanol Synthesis from Carbon Dioxide," Catalysis Today Vol. 10, (1991), pp. 293-301.

80. Waugh, K. C., "The Chemical State of Copper during Methanol Synthesis," L. Catal. Vol. 97, (1986), pp. 280-283.

81. Bowker, M., Houghton, H. and Waugh, K. C., "Mechanism and Kinetics of Methanol Synthesis on Zinc Oxide," I. Chem. Soc. Faraday Trans. 1, Vol. 77, (1981), pp. 3023-3036.

82. Vedage, G. A., Herman, R. G. and Klier, K., "Chemical Trapping of Surface Intermediates in Methanol Synthesis by Amines," J. Catal., Vol. 95, (1985), pp. 423-434.

83. Robinson, W. R. A. M. and Mol, J. C., "Temperature-Programmed Desorption Study on Supported Copper-Containing Methanol Synthesis Catalysts", Applied Catalysis A: General, Vol. 98, (1993), pp. 81-97.

84. Smith, K. J., and Anderson, R. B., "A Chain Growth Scheme for the Higher Alcohols Synthesis," L. Catal. Vol. 85, (1984), pp. 428-436. 
85. Shah, Y. T. and Perrotta, A. J., "Catalysts for Fischer-Tropsch and Isosynthesis," Ind. Eng. Chem., Prod. Res. Dev. Vol. 15, No. 2, (1976), pp. $123-130$.

86. Ponec, V., "Some Aspects of the Mechanism of Methanation and Fischer-Tropsch Synthesis," Catal. Rev.-Sci. Eng. Vol. 18, No. 1, (1978), pp. 151-171.

87. Biloen, P. and Sachtler, W. M. H., "Mechanism of Hydrocarbon Synthesis over Fischer-Tropsch Catalysts," Adv. Catal., Vol. 30, (1981), pp. 165-216.

88. Salmi, Y., Bostrom, S. and Lindfors, L. -E., "A Dynamic Study of the Water-Gas Shift Reaction over an Industrial Ferrochrome Catalyst," I. Catal. Vol. 112, (1988), pp. 345-356.

89. Herington, E. F. G., "The Fischer-Tropsch Synthesis Considered as a Polymerization Reaction," Chemistry and Industry (1946), pp. 346-347.

90. Friedel, R. and Anderson R. B., "Composition of Synthetic Liquid Fuels I. Product Distribution and Analysis of C5-C8 Paraffin Isomers from Cobalt Catalyst," Lournal of the American Chemical Society, Vol. 72, (1950), pp. 1212-1215, 2307.

91. Chinchen, G. C. and Spencer, M. S., "A Comparison of the Water-Gas Shift Reaction on Chromia-Promoted Magnetite and on Supported Copper Catalysts," J. Catal., Vol. 112, (1988), pp. 232-327.

92. Orita, H., Naito, S. and Tamaru, $\mathrm{K}$., "Mechanism of Formation of $\mathrm{C}_{2}$ Oxygenated Compounds from $\mathrm{CO}+\mathrm{H}_{2}$ Reaction over $\mathrm{SiO}_{2}$-Supported $\mathrm{Rh}$ Catalysts," L. Catal. Vol. 90, (1984), pp. 183-193.

93. Gall, D., Gibson, E. J. and Hall, C. C., "The Distribution of Alcohols in the Products of the Fischer-Tropsch Synthesis," L. Appl. Chem. Vol. 2, (1952), pp. 371-380.

94. Cavani, F., Trifiro, F. and Vaccari, A., "Synthesis of Higher Alcohols," Catalysis Today, Vol. 11, No. 2, (1991), pp. 235-246.

95. Beenakker, J. J. M., "Promoter Effects in the Catalytic Conversion of Syngas into Oxygenated Products" (unpublished Ph.D. Dissertation, Leiden University, 1988). 
96. Kirk-Othmer, Encyclopedia of Chemical Technology, Vol. 16 "Oxo Process, by I. Kirshenbaum, E. J. Inchalik" (New York: John Wiley \& Sons, Inc., 1981), pp. 637-653.

97. Herman, R. G., ed., Catalytic Conversion of Synthetic Gas and Alcohols to Chemicals, "Effect of Cobalt on Synthesis Gas Reactions over Copper-Based Catalysts, by F. N. Lin and F. Pennella" (New York: Plenum, 1984), pp. 53-63.

98. Pan, W. X., Cao, R. and Griffing, G. L., "Direct Alcohol Synthesis Using Copper/Cobalt Catalysts," L. Catal. Vol. 114, (1988), pp. 447-456.

99. Baillard-Letournel, R. M., Gomez Cobo, A. J., Mirodatos, C., Primet, M. and Dalmon, J. A., "About the Nature of the Cobalt-Copper Interaction in Co-Based Catalysts for Higher Alcohols Synthesis," Catal. Let. Vol. 2, (1989), pp.149-156.

100. Emmett, P. H., ed., Catalysis. Vol. I (New York: Reinhold Publishing Corporation, 1954), Chapter 2.

101. Briggs, D. and Seah, M. P., ed., Practical Surface Analysis, (Wiley, 1990).

102. Wagner, C. D., Davis, L. E., Zeller, M. V., Taylor, J. A., Raymond, R. H. and Gale, L. H., "Empirical Atomic Sensitivity Factors of Quantitative Analysis by Electron Spectroscopy for Chemical Analysis," Surface and Interface Analysis, Vol. 3, No. 5, (1981), pp. 211-225.

103. Lapitus, A., Krylova, A., Kazanskii, V., Borovkov, V. and Zaitsev, A., "Hydrocarbon Synthesis from Carbon Monoxide and Hydrogen on Impregnated Cobalt Catalysts, Part I. Physico-Chemical Properties of 10\% Cobalt/Alumina and 10\% Cobalt/Silica," Appl. Catal. Vol. 73, (1991), pp. 65-82.

104. Baiker, A., "Catalytic Amination of Alcohols and its Potential for the Synthesis of amine," 14th Conference on Catalysis of Organic Reactions, April 27-29, paper 8, (1992). 